UNIVERSIDADE DE SÃO PAULO

FFCLRP - DEPARTAMENTO DE BIOLOGIA

PROGRAMA DE PÓS-GRADUAÇÃO EM BIOLOGIA COMPARADA

\title{
Produção e determinação das propriedades funcionais das amilases de Aspergillus niveus
}

\author{
Tony Márcio da Silva \\ Profa. Dra. Maria de Lourdes T.M. Polizeli
}

Tese apresentada à

Faculdade de Filosofia, Ciências e Letras de Ribeirão Preto da USP, como parte das exigências para a obtenção do título de Doutor em Ciências, Área: Biologia Comparada 


\section{FICHA CATALOGRÁFICA}

Silva, T. M.

Produção e determinação das propriedades funcionais das amilases de Aspergillus niveus.

Tese de Doutorado apresentada à Faculdade de Filosofia, Ciências e Letras de Ribeirão Preto, como parte das exigências para a obtenção do título de Doutor em Ciências, Área de Concentração: Biologia Comparada.

Orientadora: Polizeli, Maria de Lourdes T.M.

1.Aspergillus niveus; 2. amilase; 3. purificação 


\section{Agradecimentos}

Aos meus pais Saulo e Lazara pelo amor, educação e dedicação em todas as etapas da minha formação moral e intelectual.

Aos meus queridos irmãos Paulo Sergio, João Ismael, José Carlos, Aluísio e Elbia pelo simples fato de existirem na minha vida (amo vocês).

A minha querida Profa. Dra. Maria de Lourdes T. M. Polizeli por abrir as portas do seu laboratório e pela confiança depositada. Agradeço pelos conhecimentos, dedicação, incentivo e também pelo carinho com que sempre fui tratado.

Ao Prof. Dr. João Atílio Jorge e ao Prof. Dr. Héctor Francisco Terenzi pelas colaborações, dúvidas esclarecidas e pelas valiosas sugestões.

Ao Prof. Dr. Luis Henrique pelo apoio prestado quando cheguei a Ribeirão Preto e ao laboratório.

Aos professores colaboradores Richard Ward, José Cesar Rosa, Maria Cristina Roque-Barreira, Roberto Ruller e Ebert Seixas Hanna.

Aos amigos e supervisores de Madri, Guisan, Mateo, Palomo, Roberto e principalmente ao meu amigo Dr. Benevides pela atenção dispensada durante minha estadia no instituto de catalises.

Aos colegas colaboradores Alexandre Maller, André Damásio, Fausto Bruno, Michele Michelin, Simone e Douglas Massui.

Ao meu grande amigo e companheiro Ricardo Alarcon pelo carinho, dedicação e pela agradável convivência.

Ao Maurício de Oliveira pelo apoio sempre prestado, amizade e pela agradável convivência.

Aos colegas de laboratório Alana, Ana Vici, André, Bruninha, Cintia, Fernanda, Guilherme, Jean, Juliana, Loli, Magal, Mariele, Marita, Mateus, Murilo, Priscila, Rose, Victor, Vivian, Tatizinha e em especial a Telma pela colaboração na reta final do desenvolvimento desse trabalho, e também pelo amor e pelo carinho.

Agradeço de coração aos amigos freqüentadores da tradicional 'quinta dos amigos' Trovão, André Miotelo, Lobão, Nilmar, Willian, Raphael, Roberto, Cesar e Junior Marqueti.

Meus agradecimentos ao Juliano Marqueti por estar sempre a disposição quando foi necessário e a todos os demais funcionários da USP que contribuíram com esse trabalho.

A FAPESP pelo apoio financeiro.

A Deus pela graça de viver. 


\section{Índice Geral}

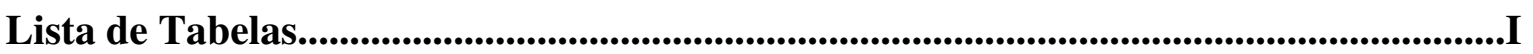

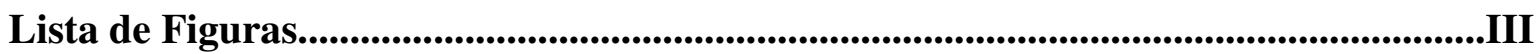

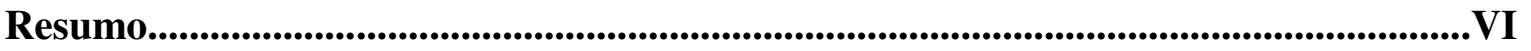

Abstract.............................................................................VIII

\section{INTRODUÇÃO}

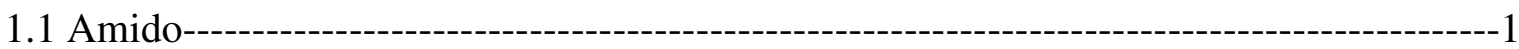

1.2 Enzimas amilolíticas e aplicações----------------------------------------------------------------5

1.3 Amilases fúngicas-----------------------------------------------------------------------------------10

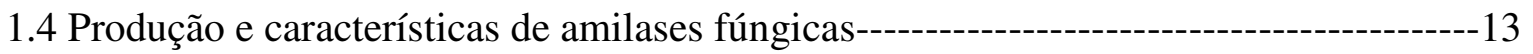

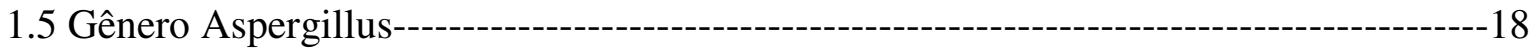

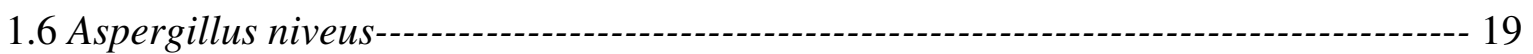

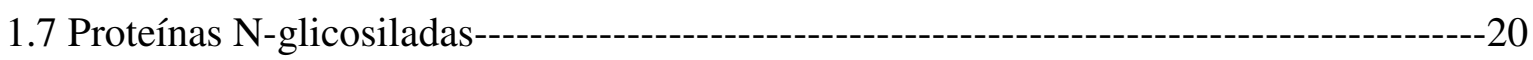

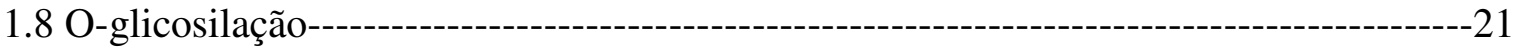

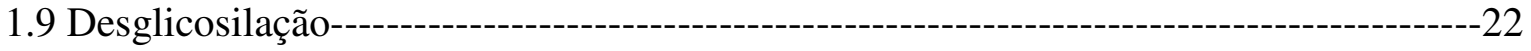

1.10 Tecnologia enzimática e imobilização de enzimas---------------------------------------23

1.10.1 Imobilização irreversível por ligação covalente---------------------------------------25

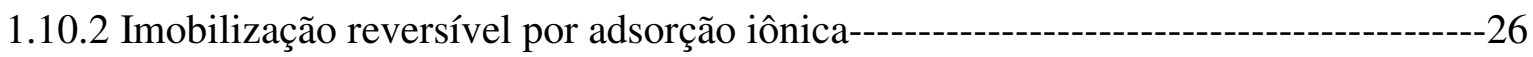

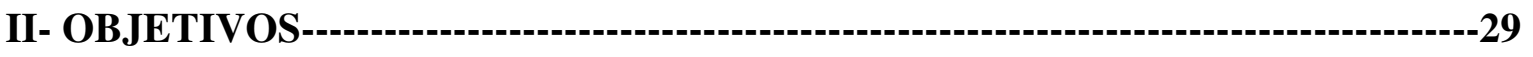

\section{III- MATERIAL E MÉTODOS}

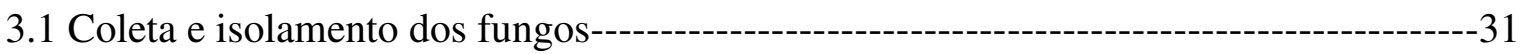

3.2 Seleção das linhagens produtoras de amilases em fermentação líquida------------------32

3.3 Manutenção das cepas em laboratório----------------------------------------------------------32 


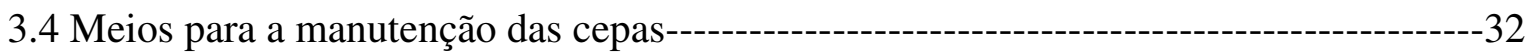

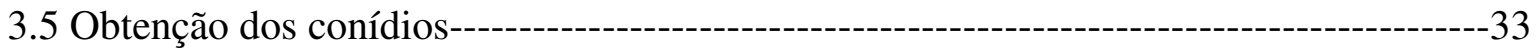

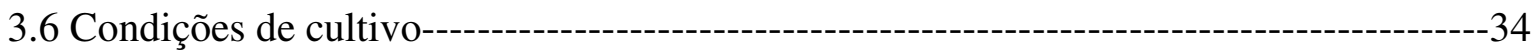

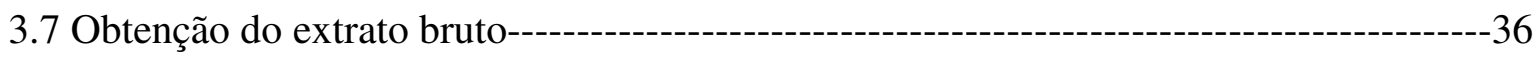

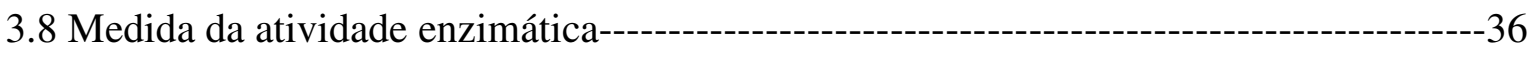

3.8.1 Determinação da atividade enzimática utilizando ácido 3,5-dinitrosalicílico (DNS)-36

3.8.2 Dosagem da atividade enzimática através da liberação de glicose (atividade de glucoamilase) usando o Kit glicose oxidase-GOD-------

3.8.3 Dosagem da atividade enzimática sobre substratos sintéticos-----------------------------38

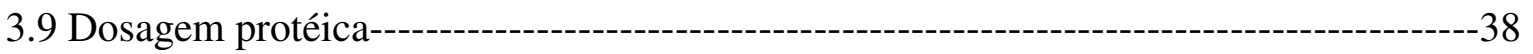

3.10 Teste de aplicabilidade em fibras alimentares------------------------------------------38

3.11 Estudo do uso da casca de mandioca como fonte de carbono-------------------------39

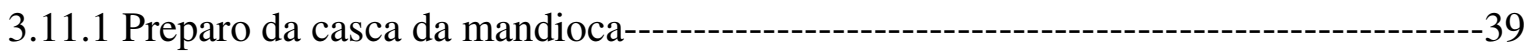

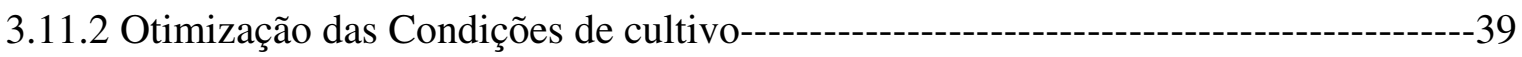

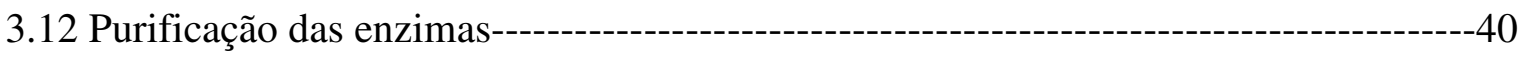

3.13 Caracterização enzimática em gel de eletroforese em condições não desnaturante

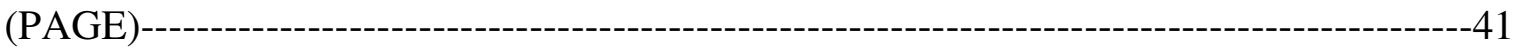

3.14 Determinação da atividade amilásica em gel de poliacrilamida (PAGE 6\%)----------41

3.15 Caracterização enzimática em gel de eletroforese em condições desnaturante (SDS-

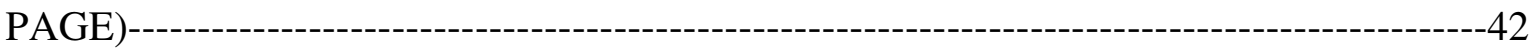

3.16 Determinação da massa molecular por cromatografia de filtração em gel--------------42

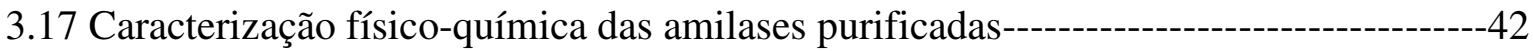

3.17.1 Efeito do $\mathrm{pH}$ e temperatura sobre a atividade das enzimas-------------------------43

3.17.2 Efeito do pH sobre a estabilidade das enzimas em ausência de substrato------------43 


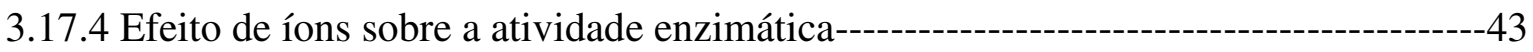

3.17.5 Efeito da adição de solventes orgânicos sobre a atividade das enzimas--------------44

3.17.6 Hidrólise de diferentes substratos pelas amilases purificadas--------------------------44

3.17.7 Cromatografia em camada delgada de sílica (TLC) dos produtos de hidrólise do amido-

3.18 Determinação do conteúdo de carboidrato e do ponto isoelétrico (pI)----------------- 45

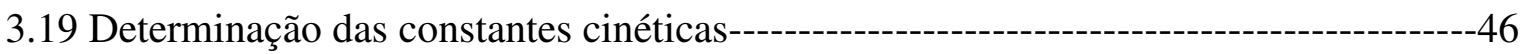

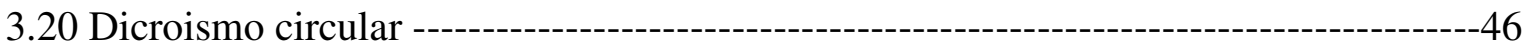

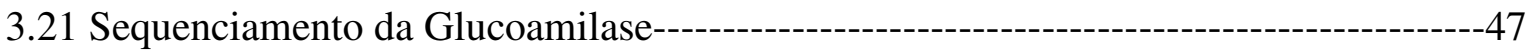

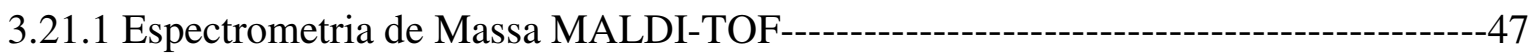

3.22 Sequenciamento das $\alpha$-glucoasidases I e II-------------------------------------------------47

3.22.1 Digestão com tripsina e extração de peptídeos do gel------------------------------------47

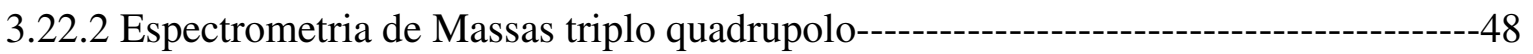

3.23 Estudo do efeito das N-glicanas nas amilases purificadas------------------------------48

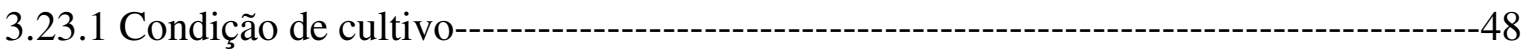

3.23.2 Purificação das amilases desglicosiladas---------------------------------------------------49

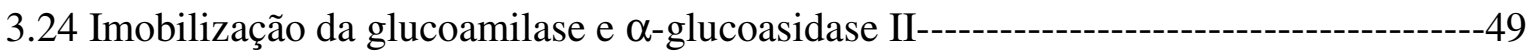

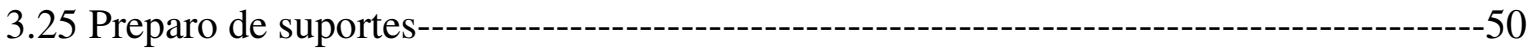

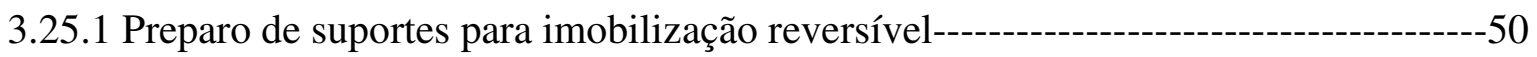

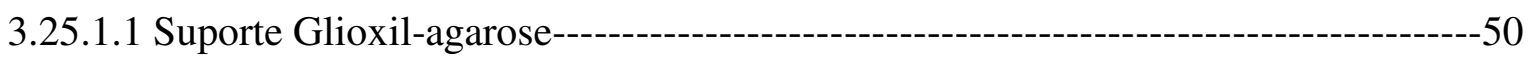

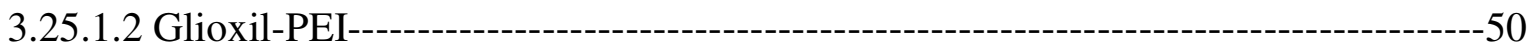

3.25.1.3 Glioxil-amino (MANAE)------------------------------------------------------------50

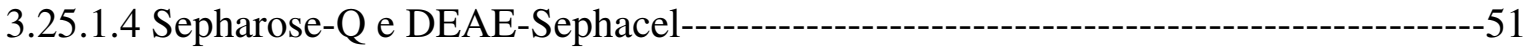

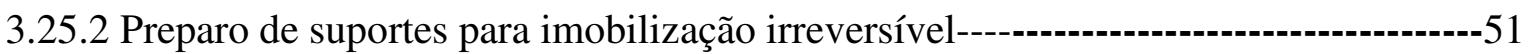

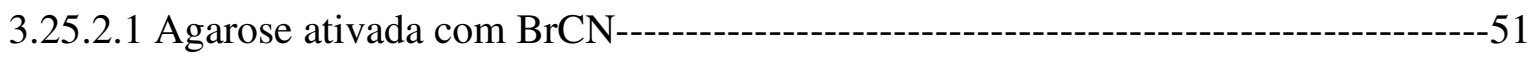




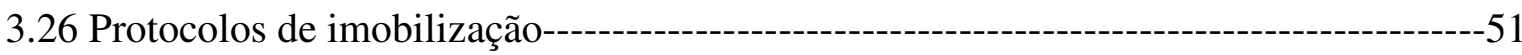

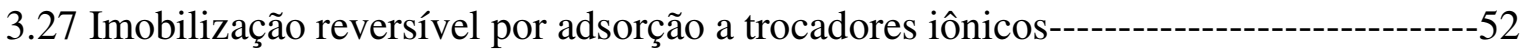

3.28 Imobilização irreversível por união covalente..........................................................52

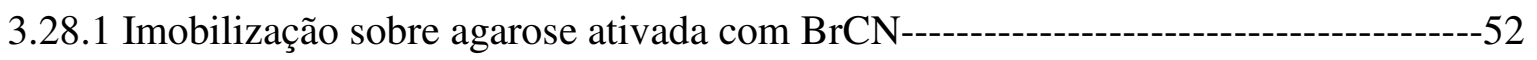

3.28.2 Imobilização sobre suporte Glioxil-agarose-----------------------------------------53

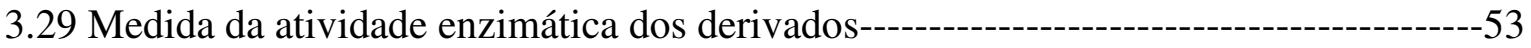

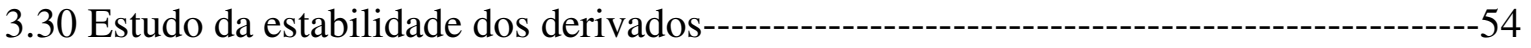

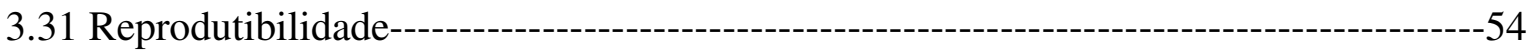

\section{IV- RESULTADOS}

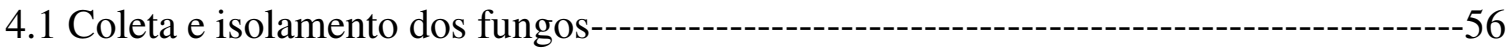

4.2 Seleção das linhagens produtoras de amilases em fermentação líquida-----------------58

4.3 Avaliação de diferentes meios de cultivo para a produção das enzimas----------------60

4.4 Avaliação da concentração de inóculo sobre a produção das amilases-------------------60

4.5 Combinação de métodos físicos visando aumento da produção enzimática------------62

4.6 Efeito do tempo de cultivo sobre a produção das amilases------------------------------63

4.7 Efeito do pH inicial de meio de cultivo sobre a produção das enzimas amilolíticas--64

4.8 Efeito da temperatura de cultivo sobre a produção das amilases------------------------64

4.9 Avaliação de diferentes fontes de carbono sobre a produção das amilases-------------66

4.10 Efeito da concentração da fonte de carbono na produção das amilases-----------------67

4.11 Efeito da adição de glicose no meio de cultivo sobre a produção de amilases--------69

4.12 Identificação dos produtos de hidrólise do amido solúvel-------------------------------70

4.13 Hidrólise de diferentes substratos pelas amilases do extrato enzimático bruto--------73

4.14 Avaliação da capacidade de hidrólise do amido solúvel e amiláceos-------------------74

4.15 Estudo da casca de mandioca como fonte de carbono---------------------------------75 
4.15.2 Efeito do $\mathrm{pH}$ inicial, temperatura e adição de amido solúvel no meio de cultivo sobre a produção das amilases$-76$

4.15.3 Análise da hidrólise de diferentes substratos por TLC e atividade amilolítica em gel de poliacrilamida (PAGE) $-78$

4.15.4- Efeito do $\mathrm{pH}$ e temperatura na atividade amilolítica das enzimas produzidas em meio com casca de mandioca$-80$

4.16 Ensaios de purificação das amilases produzidas em meio com amido solúvel como fonte indutora$-81$

4.17 Eletroforese em condições desnaturante (SDS-PAGE), não desnaturante (PAGE) e determinação da massa molecular por cromatografia em gel filtração$-85$

4.18 Determinação do conteúdo de carboidratos e ponto isoelétrico $(\mathrm{pI})$ $-88$

4.19 Efeito do $\mathrm{pH}$ e temperatura sobre a atividade e estabilidade das enzimas$-89$

4.20 Efeito de íons, EDTA e $\beta$-mercaptoetanol sobre a atividade enzimática-

4.21 Efeito da adição de solventes orgânicos sobre a atividade enzimática das amilases purificadas $-98$

4.22 Hidrólise de diferentes substratos pelas amilases purificadas $-99$

4.23 Cromatografia em camada delgada de sílica (TLC) dos produtos de hidrólise do amido$-102$

4.24 Efeito sinergístico das amilases purificadas de A. niveus sobre o amido solúvel 5\%----

4.26 Determinação das constantes cinéticas 109

4.27 Sequenciamento da glucoamilase110

4.28 Sequenciamento de peptídeos da $\alpha$-glucosidase I e $\alpha$-glucosidase II- 
4.29 Efeito de $\mathrm{N}$-glicanas nas propriedades bioquímicas de glucoamilase e $\alpha$-glucosidase II

4.29.1 Cultivo com tunicamicina e purificação das amilases 114

4.29.2 Efeito do $\mathrm{pH}$ e temperatura na atividade e estabilidade da $\alpha$-glucosidase II nativa e deglicosilada-

4.29.3 Constantes cinéticas da $\alpha$-glucosidase II nativa e deglicosilada

4.29.4 Estudo de afinidade das enzimas glucoamilase e $\alpha$-glucosidase II para $\mathrm{N}$ e $\mathrm{O}$ glicosilação-

4.30 Imobilização de glucoamilase e $\alpha$-glucosidase II-

4.30.1 Imobilização da glucoamilase-

4.30.1.1 Efeito da adição de trealose e dextrano sobre a estabilidade térmica da glucoamilase imobilizada129

4.30.1.2 Efeito do $\mathrm{pH}$ na estabilidade de glucoamilase imobilizada em $\mathrm{BrCN}$ 132

4.30.2 Imobilização de $\alpha$-glucosidase II-

4.30.2.1 Efeito da adição de trealose sobre a estabilidade térmica da $\alpha$-glucosidaseII imobilizada 134

4.30.2.2 Efeito do $\mathrm{pH}$ na estabilidade de $\alpha$-glucosidase II imobilizada em $\mathrm{BrCN}$ 136

4.30.3 Imobilização covalente de glucoamilase e $\alpha$-glucosidase II em glioxil-agarose a $\mathrm{pH}$ 10,5 137

4.30.3.1 Estabilidade térmica das amilases imobilizadas por ligações covalentes multipontuais138

4.30.3.2 Uso da trealose como aditivo na estabilidade dos derivados com ligações covalentes multipontuais-

4.30.3.3 Efeito de aditivos glicerol, polietilenoglicol e trealose na reativação dos derivados enzimáticos formados por ligações covalentes multipontuais após tratamento com guanidina $-140$ 
VI- REFERENCIAS BIBLIOGRÁFICAS--.--162

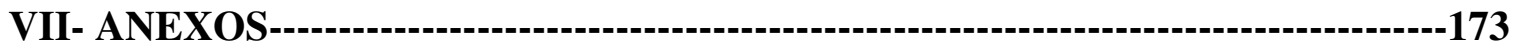




\section{Lista de Tabelas}

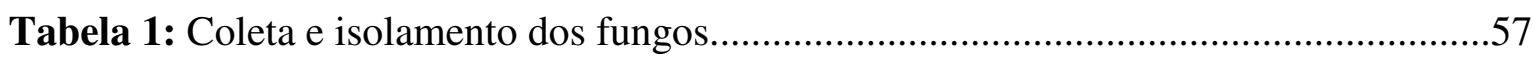

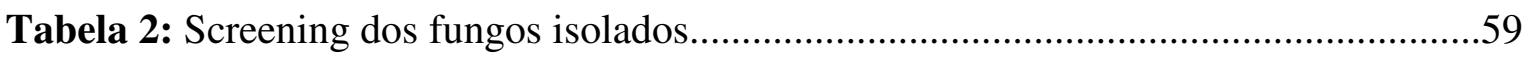

Tabela 3: Diferentes meios de cultivo na produção de amilases......................................61

Tabela 4: Efeito da concentração de inóculo sobre a produção das amilases......................61

Tabela 5: Diferentes condições de cultivo de A. niveus....................................................63

Tabela 6: Efeito do pH inicial de meio de cultivo para produção de amilases...................65

Tabela 7: Efeito da temperatura de cultivo na produção de amilases.................................66

Tabela 8: Efeito da fonte de carbono na produção de amilases.........................................68

Tabela 9: Efeito da concentração da fonte de carbono na produção das amilases..............69

Tabela 10: Efeito da adição de glicose na produção de amilases por A. niveus..................70

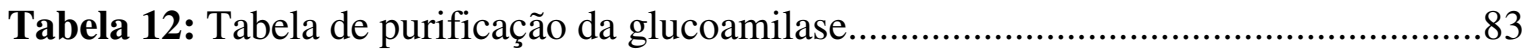

Tabela 13: Tabela de purificação das $\alpha$-glucosidases I e II..............................................84

Tabela 14: Efeito de diferentes íons, EDTA e $\beta$-mercaptoetanol, sobre a atividade enzimática da glucoamilase

Tabela 15: Efeito de diferentes íons, EDTA e $\beta$-mercaptoetanol, sobre a atividade de $\alpha$ glucosidase I

Tabela 16: Efeito de diferentes íons, EDTA e $\beta$-mercaptoetanol, sobre a atividade de $\alpha$-glucosidase II.

Tabela 17: Efeito de solventes orgânicos na atividade das amilases. .99

Tabela 18: Hidrólise de diferentes substratos pela ação da $\alpha$-glucosidase I e $\alpha$-glucosidase II. 101

Tabela 19: Efeito sinergístico das amilases purificadas sobre o amido 5\% 106

Tabela 20: Constantes cinéticas das amilases purificadas. 109

Tabela 21: Análise de sequenciamento da glucoamilase. 110

Tabela 22: Sequenciamento de aminoácidos de $\alpha$-glucosidase I 113 
Tabela 23: Sequenciamento de aminoácidos de $\alpha$-glucosidase II.

Tabela 24: Purificação da glucoamilase em meio sem tunicamicina.

Tabela 25: Purificação da glucoamilase em meio com tunicamicina. 118

Tabela 26: Purificação de $\alpha$-glucosidase I e $\alpha$-glucosidase II provenientes de meio de cultivo sem tunicamicina

Tabela 27: Purificação de $\alpha$-glucosidase I e $\alpha$-glucosidase II provenientes de meio de cultivo com tunicamicina.

Tabela 28: Efeito da tunicamicina no Km e Vmax da $\alpha$-glucosidase II .122

Tabela 29: Parâmetros de glucoamilase e $\alpha$-glucosidaseII.

Tabela 30: Sítios predicados de N-glicosilação para $\alpha$-glucosidase II.

Tabela 31: Domínios predicados de $\alpha$-glucosidase II 125

Talela 32: Potenciais sítios de N- e O-glicosilação para glucoamilase. 127 


\section{Lista de figuras}

Figura 1: Estrutura da amilose. .3

Figura 2: Estrutura da amilopectina

Figura 3: Representação esquemática da estrutura da amilopectina e modelo de ação de algumas amilases.

Figura 4: Métodos de imobilização de enzimas. 25

Figura 5: Efeito do tempo de cultivo sobre a produção de amilases.

Figura 6: Cromatografia em camada delgada dos produtos de hidrólise do amido solúvel a $1 \%$ com enzimas provenientes de meio com amido solúvel.

Figura 7: Atividade amilolítica frente a diferentes substratos usando extrato enzimático bruto. .73

Figura 8: Avaliação da capacidade hidrolítica sobre o amido e amiláceos utilizando extrato enzimático bruto .75

Figura 9: Tempo de cultivo e produção de amilases em meio de cultivo com casca de mandioca.

Figura 10: Análise dos produtos de hidrólise do amido a 1\% com enzimas provenientes de meio com casca de mandioca. .79

Figura 11: Atividade amilolítica em PAGE com enzimas de meio de cultivo com amido solúvel e casca de mandioca. .80

Figura 12: Influencia do $\mathrm{pH}$ e temperatura na atividade amilolítica das enzimas produzidas em meio com casca de mandioca.

Figura 13: Distribuição de proteínas e atividade amilásica do extrato bruto após eluição em cromatografia de troca iônica DEAE-fractogel e Concanavalina A-Sepharose.

Figura 14: Distribuição de proteínas e atividade amilásica do extrato enzimático após eluição em cromatografia por filtração Sephacryl S-200.

Figura 15: Eletroforese e representação logarítmica da massa molecular da glucoamilase. .86

Figura 16: Eletroforese e representação logarítmica da massa molecular da $\alpha$-glucosidase I..

Figura 17: Eletroforese e representação logarítmica da massa molecular da $\alpha$-glucosidase II...... 
Figura 18: Representação gráfica da focalização isoelétrica (pI) das amilases. .89

Figura 19: Efeito do $\mathrm{pH}$ e temperatura na atividade e estabilidade da glucoamilase.........91

Figura 20: Efeito do $\mathrm{pH}$ e temperatura na atividade e estabilidade da $\alpha$-glucosidase I......92

Figura 21: Efeito do $\mathrm{pH}$ e temperatura na atividade e estabilidade da $\alpha$-glucosidase II....93

Figura 22: Hidrólise de diferentes substratos pela ação da glucoamilase. 101

Figura 23: Análise em Cromatografia de Camada Delgada (TLC) dos produtos de hidrólise do amido pelas amilases purificadas. 103

Figura 24: Análise em HPLC dos produtos de hidrólise do amido 5\% pelas enzimaspurificadas. 105

Figura 25: Dicroísmo circular. 108

Figura 26: Mapa dos peptídeos trípticos obtidos da $\alpha$-glucosidase I e $\alpha$-glucosidase II. 112

Figura 27: Distribuição de proteínas e atividade enzimática do extrato enzimático após eluição em cromatografia de troca iônica DEAE-fractogel. 115

Figura 28: Distribuição de proteínas e atividade enzimática após eluição em cromatografia de exclusão por massa molecular Sephacryl-S200. 117

Figura 29: SDS-PAGE das enzimas nativas e desglicosiladas. 120

Figura 30: Efeito do $\mathrm{pH}$ e temperatura na atividade e estabilidade da $\alpha$-glucosidase II nativa e desglicosilada.

Figura 31: Atividade de $\alpha$-glucosidase II nativa e desglicosilada adsorvidas em Jacalina e Concanavalina A.

Figura 32: Potenciais sítios de N e O-glicosilação para $\alpha$-glucosidase II 132

Figura 33: Cinética de imobilização de glucoamilase em $\mathrm{BrCN}$, Sepharose-Q, GlioxilMANAE e DEAE-Sephacel e estabilidade térmica dos derivados a $60^{\circ} \mathrm{C}$ .128

Figura 34: Estabilidade térmica da glucoamilase de A. niveus imobilizada em diferentes suportes em presença de trealose a $60^{\circ} \mathrm{C}$

Figura 35: Estabilidade térmica da glucoamilase de A. niveus imobilizada em diferentes suportes em presença de dextrano a $60^{\circ} \mathrm{C}$.

Figura 36: Efeito do $\mathrm{pH}$ na estabilidade térmica de glucoamilase imobilizada em $\mathrm{BrCN}$ na presença e ausência de trealose a $65^{\circ} \mathrm{C}$. 
Figura 37: Cinética de imobilização de $\alpha$-glucosidase II em BrCN, Sepharose-Q, GlioxilPEI e DEAE-Sephacel e estabilidade dos derivados a $60^{\circ} \mathrm{C}$.

Figura 38: Estabilidade térmica de $\alpha$-glucosidase II de $A$. niveus imobilizada em agarosePEI, Sepharose-Q, DEAE-Sephacel e $\mathrm{BrCN}$ a $60^{\circ} \mathrm{C}$.

Figura 39: Efeito do $\mathrm{pH}$ na estabilidade térmica de $\alpha$-glucosidase II imobilizada em $\mathrm{BrCN}$ na presença e ausência de trealose a $63^{\circ} \mathrm{C}$

Figura 40: Cinética de imobilização covalente multipontual de glucoamilase e $\alpha$ glucosidase II em Glioxil Agarose a $\mathrm{pH}$ 10,5. 138

Figura 41: Estabilidade térmica de glucoamilase a $60^{\circ} \mathrm{C}$ e $\alpha$-glucosidase II a $63^{\circ} \mathrm{C}$

Figura 42: Efeito da trealose na estabilidade térmica das enzimas imobilizadas por ligações covalentes multipontuais. 140

Figura 43: Efeito de aditivos glicerina, polietilenoglicol e trealose na reativação de glucoamilase (A) e $\alpha$-glucosidase II.... 


\section{RESUMO}

Este trabalho objetivou coletar e isolar fungos filamentosos de diferentes regiões do estado de São Paulo com potenciais para produção de enzimas amilolíticas com características físico-químicas desejáveis para aplicação industrial. Foram coletados 19 fungos nas três coletas realizadas e estes juntamente com outros cinco fungos, isolados anteriormente durante o projeto Biota/FAPESP, foram submetidos a uma seleção para a escolha do melhor produtor de amilases. Aspergillus niveus foi o que melhor produziu amilases nas condições avaliadas e foi tomado para dar continuidade ao trabalho.

A etapa seguinte consistiu em avaliar as melhores condições de cultivo para a produção das amilases. Os maiores níveis de atividade enzimática foram detectados em meio Khanna, em cultivos estáticos, $\mathrm{pH}$ inicial 6,0 , a $40^{\circ} \mathrm{C}$, com 72 horas de crescimento. Milho moído, farinha de aveia, palha de arroz, maisena, amido solúvel, casca de mandioca, maltose, farelo de trigo, penetrose, amilopectina e rafinose foram as fontes de carbono que melhor induziram a síntese de amilases. Extratos enzimáticos de A. niveus obtidos sob condições ótimas de cultivo, foram submetidos a eluição em diferentes colunas cromatográficas (DEAE-Fragtogel e Sephacryl S-200) e três amilases foram purificadas (uma glucoamilase e $2 \alpha$-glucosidases- I e II), cujas massas moleculares determinadas por SDS-PAGE corresponderam à 77, 59 e $55 \mathrm{kDa}$. Os pontos isoelétricos e o conteúdo de carboidrato corresponderam respectivamente a de 3,8 e $15 \%$ para glucoamilase, 6,6 e $4 \%$ para $\alpha$-glucosidase I e 6,8 e $29 \%$ para $\alpha$ glucosidase II. O pH ótimo para atividade de glucoamilase foi de 5,0-5,5 e pH 6,0 para a atividade de $\alpha$-glucosidase I e II. A temperatura ótima para as três enzimas foi de $65^{\circ} \mathrm{C}$ e as mesmas apresentaram boa estabilidade a 60 e $65^{\circ} \mathrm{C}$. A glucoamilase apresentou alta afinidade para o amido, já a $\alpha$-glucosidase I apresentou alta afinidade para amido, glicogênio e maltose. A maior eficiência catalítica foi verificada na presença de 
glicogênio, seguido de amido e maltose. A $\alpha$-glucosidase II apresentou atividade sobre vários substratos e os valores de $\mathrm{K}_{\mathrm{cat}} / \mathrm{K}_{\mathrm{m}}$ obtidos mostraram maior preferência dessa enzima pelo glicogênio, seguido de amido, amilopectina, maltose e $\alpha$ - $\rho$ NPG. A análise de Dicroísmo Circular demonstrou que as três amilases são ricas em $\alpha$-hélices nas suas estruturas secundárias e o sequenciamento de aminoácidos revelou similaridade da glucoamilase de A. niveus com glucoamilases de A. terreus, A. niger, A. ficcum, A. awamori, A. kawachi e A. shirousami. O sequenciamento das $\alpha$-glucosidases I e II revelaram homologia destas com $\alpha$-glucosidase de A. fumigatus. Estudos do efeito de $\mathrm{N}$-glicanas nas propriedades das enzimas foram avaliados mediante tratamento do meio de cultivo com tunicamicina. A glucoamilase e a $\alpha$-glucosidase I perderam significativamente a especificidade pelo substrato, já a $\alpha$-glucosidase II perdeu termoestabilidade com a remoção das N-glicanas. Glucoamilase e $\alpha$-glucosidase II foram imobilizadas em suportes com interação iônica e por ligação covalente. Os suportes trocadores iônicos usados foram Glioxil-PEI, Glioxil-MANAE, DEAESephacel e Sepharose Q. Os suportes utilizados para interação covalente foram agarose ativada com brometo de cianogênio (BrCN) e Glioxil-Agarose, $\mathrm{pH}$ 10,5. A estabilidade apresentada com os derivados formados por ligações covalentes foi maior que aquela apresentada para os derivados formados a partir de ligações iônicas. $\mathrm{O}$ uso da trealose como aditivo aumentou significativamente a estabilidade de todos os derivados. 


\section{ABSTRACT}

This study aimed to collect and isolate filamentous fungi from different regions of São Paulo state with potential for amylases production with desirable physical and chemical characteristics for industrial application. It was collected 19 fungi during three different expeditions. These fungi with other five microorganisms previously isolated during the Biota project were submitted to screening tests to select a good amylases producer. Aspergillus niveus was one of the best amylase producers under experimental conditions and was chosen to continue this work.

The next step was to determine the best growth conditions for the amylases production. The highest levels of enzymatic synthesis were detected in Khanna medium under static conditions, initial $\mathrm{pH} 6.0$, at $40^{\circ} \mathrm{C}$ during 72 hours. Corn, oatmeal, rice straw, corn starch, soluble starch, cassava peel, maltose, wheat bran, penetrose, amylopectin and raffinose were the best carbon sources for amylase production. Enzymatic extracts from A. niveus obtained under the optimal culture conditions, were loaded in different chromatography columns (DEAE-Fragtogel and Sephacryl S200) where three amylases were purified (a glucoamylase and two $\alpha$-glucosidases, named I and II), whose molecular weights determined by SDS-PAGE corresponded to 77, 59 and $55 \mathrm{kDa}$. The isoelectric points and carbohydrate content were 3.8 and $15 \%$ for glucoamylase, 6.6 and $4 \%$ for $\alpha$-glucosidase I and 6.8 and $29 \%$ for $\alpha$-glucosidase II, respectively. The glucoamylase optimum $\mathrm{pH}$ was 5.0-5.5 and 6.0 for $\alpha$-glucosidases I and II. The optimum reaction temperatures were $65^{\circ} \mathrm{C}$ for all studied enzymes and all of them showed stability at 60 and $65^{\circ} \mathrm{C}$. The glucoamylase presented high affinity for starch and $\alpha$-glucosidase I presented high affinity for starch, glycogen and maltose. The highest catalytic efficiency was observed using glycogen, starch and maltose as substrates. The $\alpha$-glucosidase II hydrolyzed several substrates and the $\mathrm{kcat} / \mathrm{Km}$ values showed greater performance under glycogen, followed by starch, amylopectin, maltose and $\alpha-\rho N P G$ hydrolysis. The Circular Dichroism (CD) analyses showed that all the studied amylases were predominantly constituted by $\alpha$-helices in its secondary structure. The amino acid sequencing revealed similarity among the glucoamylase from $A$. niveus, A. terreus, A. niger, A. ficcum, A. awamori, A. kawachi and A. shirousami. Comparing the sequencing of $\alpha$-glucosidases I and II from A. niveus, both showed homology with other $\alpha$-glucosidases from $A$. fumigatus. Studies about the effect of $\mathrm{N}$-glycans under enzymatic properties were done by addition of tunicamycin in the culture medium. Glucoamylase and $\alpha$-glucosidase I lost significantly their substrate specificity, and $\alpha-$ glucosidase II lost its thermostability after the N-glycans removal. Glucoamylase and $\alpha$ glucosidase II were immobilized in ionic interaction supporters and by covalent bonds. The ion exchangers supporters used were glyoxylic-PEI, glyoxylic-MANA, DEAESephacel and Sepharose Q. The supporters used for covalent interaction were agarose activated with cyanogen bromide (BRCN) and glyoxylic-Agarose, $\mathrm{pH}$ 10.5. The stability presented with derivatives formed by covalent bonds was higher than those reported for the derivatives formed from ionic bonds. The use of trehalose as an additive really improved the stability of all derivatives. 


\section{1- Amido}

O amido é um dos polímeros mais abundantes na natureza e depois da celulose, é o principal carboidrato sintetizado pelas plantas. Uma substância de reserva para a maioria das plantas superiores, composto inteiramente de D-glicose, esse polímero constitui também uma fonte de energia essencial para muitos organismos, inclusive o homem. Esse polissacarídeo é facilmente assimilado na dieta humana e representa uma das principais fontes de energia alimentar em todo o mundo, já que é encontrado em grande quantidade no milho, batata, trigo e arroz, que constituem a base da alimentação da maioria das populações. O amido presente nos vegetais pode ser hidrolisado, gerando glicose, maltose, e xaropes de oligossacarídeos de menores massas moleculares, que por sua vez podem ser utilizados para a produção de outros compostos químicos e também como substratos em fermentações (VIEILLE \& ZEIKUS, 2001).

O amido é acumulado nos vegetais na forma de grânulos insolúveis, os quais são compostos basicamente de dois polímeros quimicamente muito parecidos: a amilose e a amilopectina, que aparecem na proporção média de 25 e $75 \%$, respectivamente. A amilose (Fig. 1) é essencialmente formada por cadeias lineares helicoidais constituídas de unidades de glicose unidas por ligação glicosídica $\alpha-1,4$ enquanto que a amilopectina (Fig. 2) é formada por uma estrutura altamente ramificada, possuindo cadeias de resíduos de glicose em ligação glicosídica $\alpha-1,4$, das quais partem ramificações com ligações $\alpha-1,6$ a cada série de 25 resíduos de glicose (LASZLO et al., 1986). 


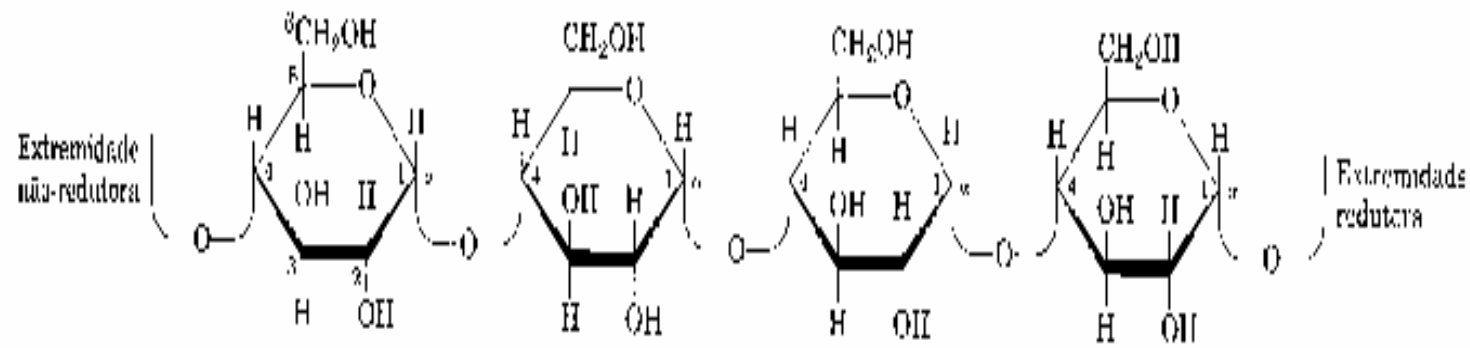

(A)

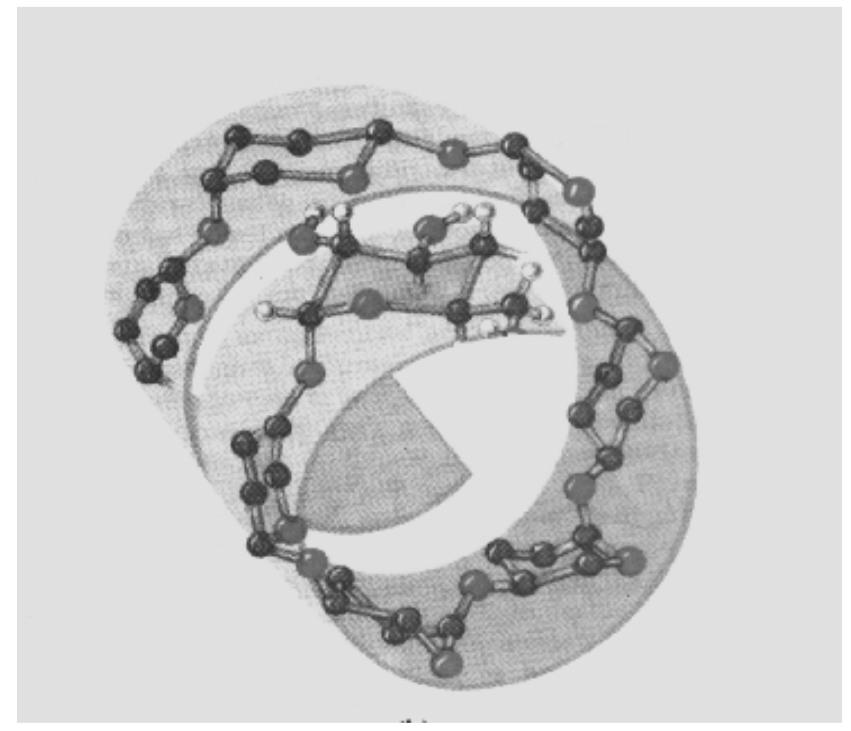

(B)

Figura 1: Estrutura da amilose. A cadeia linear é composta por D-glicose unidas por ligações $(\alpha-1 \rightarrow 4)$. (A) Estrutura da amilose; (B) Estrutura helicoidal compacta (LEHNINGER et al., 1995). 


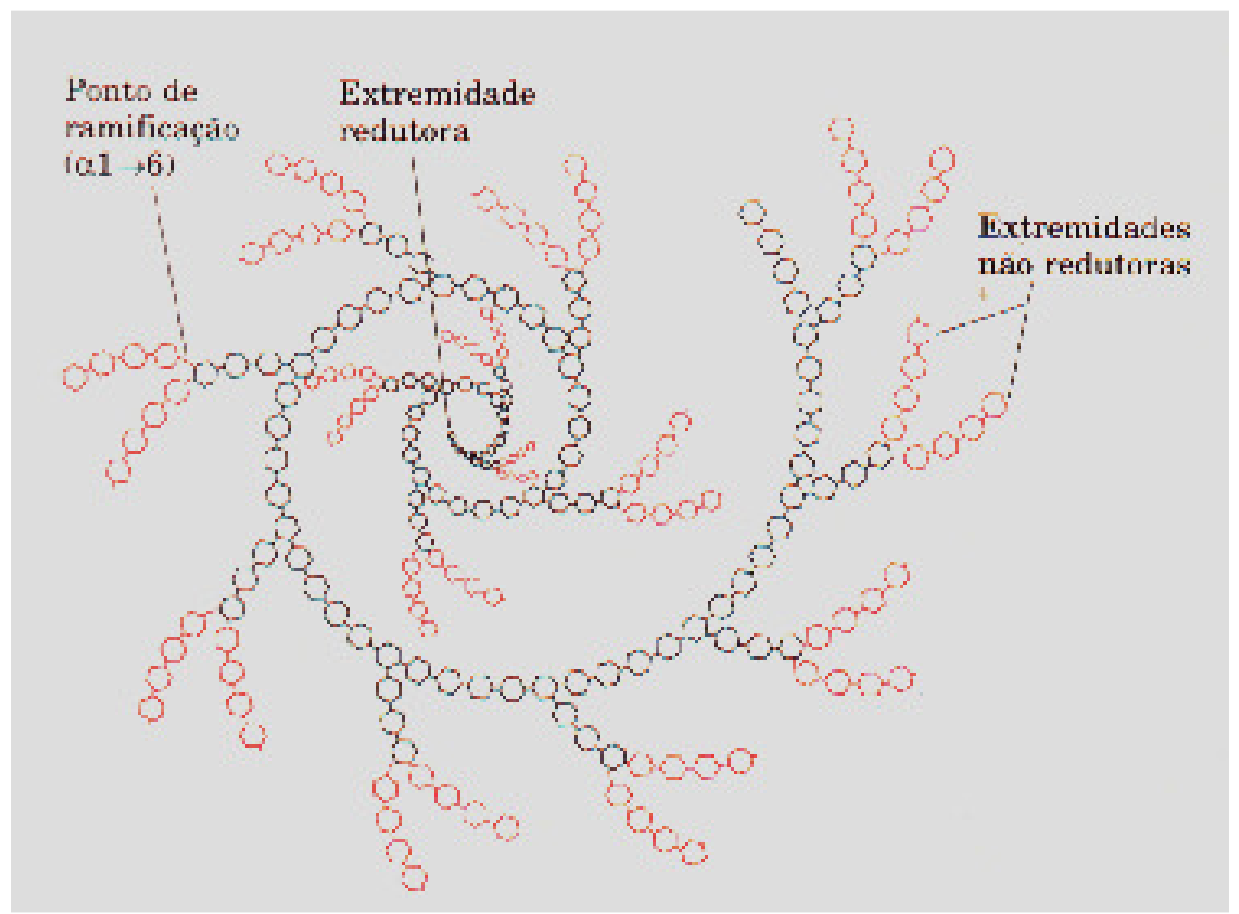

Figura 2: Estrutura da amilopectina. Cada um dos hexágonos representa um resíduo de glicose. (LEHNINGER et al., 1995).

Grande parte do amido produzido é destinada às indústrias de alimentos. Geralmente, o amido ajuda na melhoria das propriedades funcionais dos alimentos e supre a falta de oligossacarídeos, dissacarídeos e monossacarídeos (GUZMÁN-MALDONADO \& PAREDES-LOPEZ, 1995).

Nas indústrias de alimentos, o amido tem sido convertido por ação enzimática em:

1- dextrinas, que são utilizadas em formulações clínicas, como material para sacarificação enzimática, estabilizadores e espessantes;

2- maltose, que é utilizada em confeitarias, na fabricação de refrigerantes, cervejas, geléias e sorvetes;

3- glicose, utilizada em refrigerantes, panificação, cervejarias e como subsídio para a produção de etanol e outros bioprodutos; 
4- frutose, utilizada em refrigerantes, geléias e iogurtes.

Parte da produção de amido é utilizada em outros tipos de indústrias, tais como de papel, tecido e embalagens, as quais utilizam o amido como aglutinante de fibras e como adesivo.

\section{2- Enzimas amilolíticas e aplicações}

Amilases são enzimas capazes de hidrolisar as ligações glicosídicas $\alpha-1,4$ da molécula de amido. São enzimas utilizadas pelas plantas para degradar o amido que é acumulado em alguns tipos de raízes; por animais, para a digestão do amido contido na maioria dos alimentos e por muitos microrganismos procariotos e eucariotos que usam o amido como fonte de carbono (PEIXOTO et al., 2003).

As amilases podem ser divididas em duas categorias quanto ao seu modelo de ação: as endoamilases e as exoamilases. As endoamilases hidrolisam as ligações glicosídicas ao acaso no interior da molécula de amido liberando oligossacarídeos e as exoamilases hidrolisam, sucessivamente, as ligações glicosídicas a partir da extremidade não redutora da molécula, liberando glicose ou maltose (GUZMÁN-MALDONADO \& PAREDES-LOPEZ, 1995). Um modelo de ação conjunta de algumas amilases sobre o complexo amilolítico é descrito resumidamente na Figura 3. 


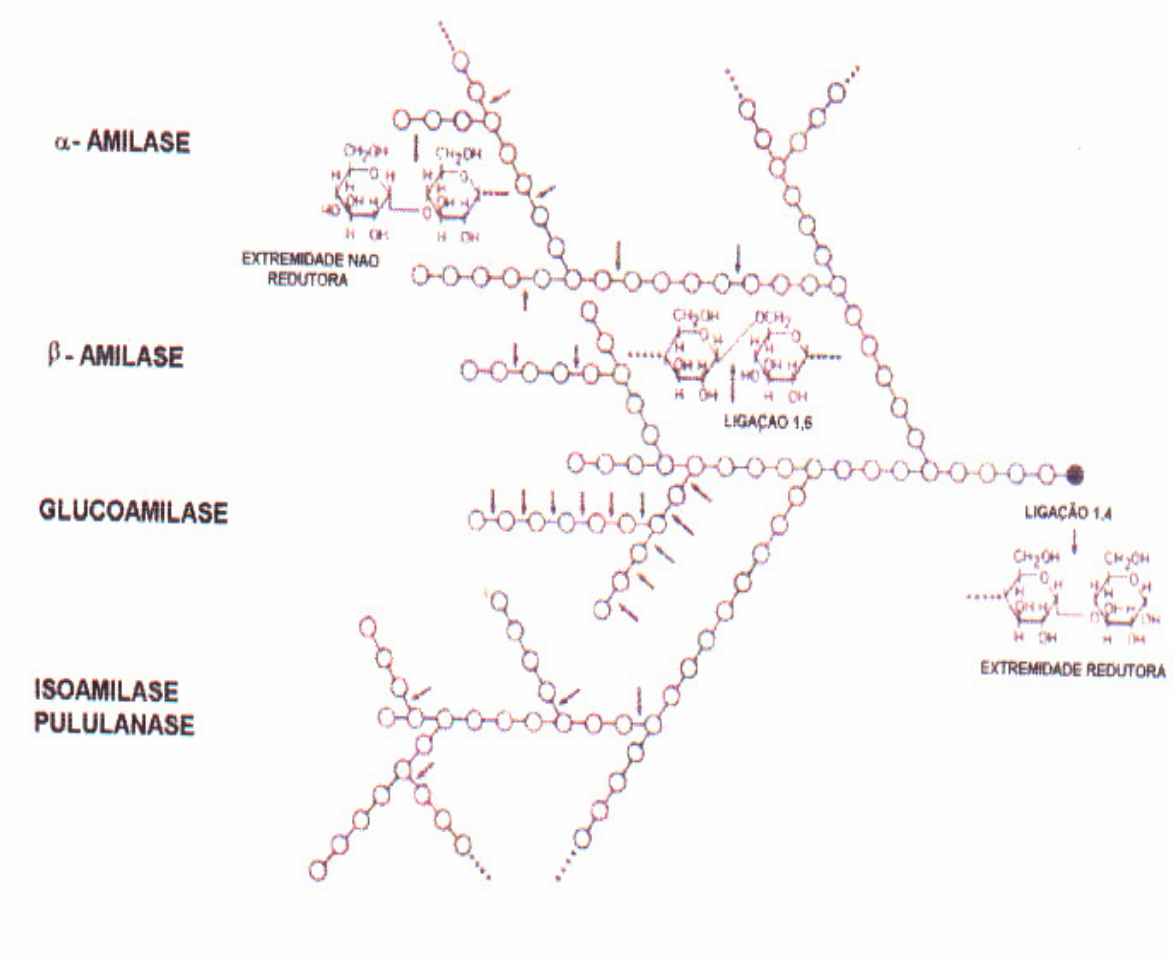

Figura 3: Representação esquemática da estrutura da amilopectina e modelo de ação de algumas amilases (VIHINHEN \& MÄNTSÄLÃ, 1989).

A seguir, são descritas as amilases que atuam na conversão do amido em compostos de baixa massa molecular (VIHINEN \& MÄNTSÄLÄ, 1989; ANTRANIKIAN et al., 1995):

$\alpha$-amilases (EC 3.2.1.1 1,4- $\alpha$-glucano glucanohidrolase): são endoenzimas que hidrolisam as ligações glicosídicas $\alpha-1,4$ internas da amilose e amilopectina, liberando oligossacarídeos de cadeias com comprimentos variáveis. São também chamadas de enzimas dextrinizantes e podem ser divididas em duas categorias de acordo com o grau de hidrólise do substrato: $\alpha$-amilases liqueficantes, que quebram de 30 a $40 \%$ do substrato, e as $\alpha$-amilases sacarificantes, que hidrolisam de 50 a $60 \%$ do substrato; 
$\beta$-amilases (EC 3.2.1.2 1,4 $\alpha$-D-glucano maltohidrolase): são exoenzimas que hidrolisam a penúltima ligação $\alpha-1,4$ a partir da extremidade não redutora da cadeia de amido, liberando unidades de $\beta$-maltose. A amilose é completamente convertida em maltose enquanto o índice de conversão de amilopectina em maltose gira em torno de 50 a $60 \%$, dependendo do grau de ramificação;

Glucoamilases (GA) (EC 3.2.1.3 1,4- $\alpha$-D-glucano glucohidrolase): são exoenzimas que hidrolisam as ligações glicosídicas $\alpha-1,4$ e $\alpha-1,6$ da molécula de amido. Elas liberam unidades de $\beta$-D-glicose a partir da extremidade não redutora do substrato. As glucoamilases são também chamadas de enzimas de sacarificação, pois são capazes de hidrolisar completamente o amido em incubação por longo tempo;

$\alpha$-D-glucosidases (EC 3.231.20 $\alpha$-D-glucosídeo glucohidrolase): em geral são enzimas de origem microbiana e hidrolisam as ligações $\alpha-1,4$ e $\alpha-1,6$ de polissacarídeos como amido e glicogênio e oligossacarídeos de cadeia curta, os quais são formados pela ação de outras amilases, liberando unidades de D-glicose a partir da extremidade não redutora. $\mathrm{Na}$ literatura são descritos três principais tipos de $\alpha$-glucosidases, o tipo I apresenta maior afinidade por glicosídeos aril como $p$-nitrofenil glucopiranosideo ( $p$ NPG) comparado com oligossacarídeos curtos, já o tipo II são mais ativas em maltose do que glicosídeos aril e o tipo III é similar ao tipo II porém hidrolisa amido e oligossacarídeos com a mesma velocidade. Existem ainda as que sintetizam maltooligossacarídeos através de maltose por um processo conhecido como transglicosilação.

Exo-(1,4)- $\alpha$-D-glucanases (EC 3.2.1.60 / 3.2.1.98): são exoamilases que ao invés de liberar sucessivas unidades de maltose, como ocorre com a $\beta$-amilase, liberam, por exemplo, maltotetraose e maltohexaose como os maiores produtos da ação da enzima sobre o amido; 
Pululanases (EC 3.2.1.41 $\alpha$-dextrina-6-glucanohidrolase): são enzimas que hidrolisam as ligações $\alpha-1,6$ do pululano e de outros oligossacarídeos. O produto dessa hidrólise corresponde as maltotrioses;

Isopululanases (EC 3.2.1.57 pululano-4-glucanohidrolase): são enzimas que hidrolisam também as ligações glicosídicas $\alpha-1,4$ do pululano, mas que não tem nenhuma atividade sobre o amido. O produto final da ação dessas enzimas é a isopanose;

Isoamilases (EC 3.2.1.68 glicogênio-6-glucanohidrolase): hidrolisam as ligações $\alpha$ 1,6 da amilopectina, glicogênio e oligossacarídeos, mas não hidrolisam a ligação $\alpha-1,6$ do pululano;

Ciclomaltodextrina D-glucotransferase (CGTase) (EC 2.4.1.19 1,4- $\alpha$-D-(1,4-DGlucano) transferase): são exoenzimas que hidrolisam o amido por meio de reações complexas formando oligossacarídeos cíclicos não redutores, conhecidos como ciclodextrinas.

No processamento industrial do amido, duas etapas principais podem ser identificadas: a liquefação e a sacarificação. Em um primeiro estágio, o amido é gelatinizado sob uma temperatura de $110^{\circ} \mathrm{C}$ até que se torne solúvel. O amido gelatinizado é submetido ao processo de liquefação que é realizado pela ação de $\alpha$-amilase termoestável obtida de Bacillus subtilis, B. amyloliquefaciens $e$ B. licheniformis, que liberam maltodextrinas com baixo DE (equivalente em dextrose) como produto final (VIHINEN \& MÄNTSÄLÄ, 1989). Após a completa liquefação, o material é resfriado a aproximadamente a $60^{\circ} \mathrm{C}$ para o passo da sacarificação, que consiste na completa transformação do amido liquefeito em glicose. Nesse processo, geralmente, utiliza-se glucoamilases de Aspergillus niger. A glicose, por isomerização pela glicose isomerase, pode ser convertida em frutose. 
Outras enzimas amilolíticas como $\beta$-amilase e pululanases, também podem ser empregadas na sacarificação. Nesse caso, o produto final vai consistir em xarope de maltose (GLAZER \& NIKAIDO, 1995; HAKI \& RAKSHIT, 2003).

A utilização dessas enzimas no processamento de alimentos tem sido muito vantajosa, pois além do rendimento ser semelhante ou maior do que o do processamento químico, não há formação de compostos não desejados. Além disso, as enzimas amilolíticas têm a vantagem de catalisar reações sob condições moderadas, além de serem naturais e não tóxicas. Essas capacidades as tornam imprescindíveis para a indústria de alimentos, além de que, a maioria das enzimas é ativa em baixas concentrações (FENEMA, 1985).

As amilases têm ganhado um papel importante na conversão do amido em álcool utilizando-se, simultaneamente, a sacarificação e a fermentação (SINGH et al. 1995; KOBAYASHI et al. 1998). A aplicação das amilases na produção de etanol tem solucionado, em parte, os problemas que alguns paises apresentam em função da escassez de reservas de combustível. Nesse processo, glucoamilases e $\alpha$-amilases de $A$. niger são adicionadas em meio fermentativo contendo células de Saccharomyces cerevisiae. O amido presente no meio fermentativo é convertido, através da ação conjunta das amilases, em glicose que posteriormente é convertida por fermentação em etanol (RAJOKA et al., 2004).

As amilases, mais especificamente a $\alpha$-amilase, tem sido usada na indústria papeleira com o propósito de diminuir a viscosidade da goma de amido que é empregada sobre o papel durante o processamento do mesmo. A ação da $\alpha$-amilase sobre a camada de amido utilizada no revestimento do papel também contribui para a sua qualidade final (GUPTA et al., 2003). As $\alpha$-amilases têm sido utilizadas nas formulações de detergentes líquidos para reduzir em parte, a agressividade dos detergentes sobre madeiras e porcelanas (GUPTA et al. 2003). Segundo KOTTWITZ e outros (1995), 90\% dos detergentes líquidos contêm $\alpha$-amilase em 
suas formulações. Algumas limitações do uso de $\alpha$-amilases na composição dos detergentes consistem no fato de que, a maioria dessas enzimas demonstra sensibilidade ao cálcio e sua estabilidade pode ser severamente comprometida em baixas concentrações desse íon, e também na presença de alguns agentes oxidantes (GUPTA et al., 2003).

\section{3- Amilases fúngicas}

A aplicação de fungos em processos, cujos produtos são comercialmente importantes, tem aumentado com o passar das décadas. A utilização desses microrganismos pelo homem não é um fenômeno recente, pois se sabe que desde a época dos antigos egípcios já se fazia o uso desses organismos em processos fermentativos para a produção de bebidas alcoólicas (PAPAGIANNI, 2004).

Os fungos, em geral, podem ocupar muitos diferentes ambientes como solos, materiais orgânicos em decomposição, plantas, dentre outros. Essa diversidade de ambientes, evolutivamente garantiu a esses organismos a capacidade de sintetizar uma série de enzimas com diferentes características, possibilitando-lhes o uso da matéria orgânica do meio como fonte de carbono (GOUKA et al., 1997).

Nas últimas décadas, a utilização de fungos em bioprocessos ganhou importância devido à produção de inúmeras enzimas com características físico-químicas variadas e com excelentes potenciais para a aplicação industrial. A capacidade de síntese em grande escala, bem como a facilidade com que são excretadas para o meio externo, constituem algumas dessas características (IWASHITA, 2002). Dentre essas inúmeras enzimas, as amilases aparecem como uma das mais importantes.

As amilases são derivadas de várias fontes, incluindo plantas, animais e microrganismos. Microrganismos como fungos, bactérias, leveduras e actinomicetos são potenciais produtores de amilases; porém, as produzidas por fungos e bactérias têm dominado 
a maioria do setor industrial (PANDEY et al., 2000). Dentre as amilases sintetizadas por fungos, as $\alpha$-amilases e as glucoamilases são as que aparecem com maiores freqüências. A $\alpha$ amilase é produzida por muitos gêneros de fungos filamentosos e leveduras. As $\alpha$-amilases produzidas por algumas bactérias como, por exemplo, Bacillus sp, B. amyloliquefaciens e $B$. liqueniformes, com aplicação comercial, são hoje preferidas em relação àquelas produzidas por fungos e leveduras, por apresentar algumas características desejáveis, tais como a termoatividade e a termoestabilidade, podendo assim ser aplicada em processos que ocorrem em altas temperaturas (PANDEY, 2000). Entretanto, $\alpha$-amilases bacterianas não apresentam a capacidade sacarificante de algumas $\alpha$-amilases fúngicas. Assim, parece ser necessária a produção de enzimas fúngicas que apresentem termoestabilidade semelhante àquelas das bactérias.

As glucoamilases são oriundas de várias fontes como plantas, animais e microrganismos em geral e catalisam eficientemente a reação de sacarificação do amido dentro de um limite estreito de temperatura, isto porque, a conformação cataliticamente ativa das glucoamilases usadas na indústria é alterada com o aumento da temperatura, o que afeta seu uso no processo industrial, onde a conservação prolongada em altas temperaturas é necessária.

As glucoamilases comercialmente disponíveis são, em sua maior parte, produzidas por linhagens de Aspergillus e Rhizopus. As glucoamilases de Aspergillus são mais termoestáveis, com atividade máxima entre 50 e $55^{\circ} \mathrm{C}$, sendo elas rapidamente inativadas em temperaturas próximas de $60^{\circ} \mathrm{C}$ (ZAHA \& ZEIKUS, 1989). Além da capacidade de produção em alta escala, algumas espécies de Aspergillus podem sintetizar mais de uma forma da mesma enzima com características diferenciadas, comparadas com aquelas sintetizadas por bactérias com características e propriedades únicas (KUMAR et al., 2004). 
Além de espécies do gênero Aspergillus, espécies de outros gêneros como Rhizopus, Mucor, Humicola e Thermomyces, dentre outros, aparecem na literatura como potenciais produtores de amilases, com destaque para a produção de amilases por Rhizopus oligosporus DAR 2710, R. microsporus, Rhizopus sp, Mucor pusillus, Thermomucor, Humicola grisea, Thermomyces lanuginosus, T. lanuginosus ATCC 34626 e Rhizomucor pusillus A 13.36 (JIN et al., 1999; PEIXOTO et al., 2003; CRUZ et al., 1997; SOMKUTI \& STEINBERG, 1980; KAUR \& SATYANARAYANA, 2004; TOSI et al., 1993, MISHRA \& MAHESHWARI, 1996; NGUYEN et al., 2000; SILVA et al., 2005, respectivamente).

Os fungos unicelulares, mais conhecidos por leveduras, assim como os fungos filamentosos, estão espalhados pelos mais distintos ecossistemas. Essa diversidade de ambientes habitados por esses microrganismos tem possibilitado aos pesquisadores o isolamento de espécies com características desejáveis para a indústria (SKORUPA et al., 2002). A capacidade de degradação do amido por algumas espécies de leveduras tem sido determinante para sua aplicação em processos biotecnológicos como fontes de enzimas hidrolíticas para a produção de etanol (DE MOT, 1984).

A produção de enzimas amilolíticas, por leveduras, não tem recebido muito destaque em função do pequeno volume em que são excretadas, embora se saiba que estas enzimas são produzidas pela maioria das espécies. Dentre aquelas conhecidas como produtoras de amilases ganham destaque: Schwanniomyces alluvius, Lipomyces konomenkoae, e Cryptococcus flavus (WILSON \& INGLEDEW, 1982; PRIETO et al., 1995 e SKORUPA et al., 2002, respectivamente).

A deficiência de produção em alta escala tem sido suprida nos últimos anos através do amplo conhecimento em biologia molecular, juntamente com a elaboração e aplicação de novas técnicas de DNA recombinante em algumas espécies de levedura (SHIRAGA et al., 2004; MOLLER et al., 2004). 


\section{4- Produção e características de amilases fúngicas}

Com o intuito de viabilizar economicamente a hidrólise do amido, vários fungos com excelente potencial para produção de amilases têm sido isolados nos últimos anos. Alguns trabalhos têm reportado a produção de diferentes tipos de amilases fúngicas termoestáveis e termotolerantes, com características físico-químicas variadas e viáveis para a aplicação em bioprocessos.

SOMKUTI \& STEINBERG (1980) estudaram as características físico-químicas de uma $\alpha$-amilase extracelular produzida por $M$. pusillus, em fermentação líquida, utilizando farelo de trigo como fonte de carbono a $34^{\circ} \mathrm{C}$. A enzima apresentou um $\mathrm{pH}$ ótimo de atividade entre 3,5 e 4,0, uma atividade ótima em $70^{\circ} \mathrm{C}$. A mesma enzima foi inibida na presença de 10 $\mathrm{mM}$ de íons $\mathrm{Mg}^{+2}, \mathrm{Ca}^{+2}$ e $\mathrm{Cu}^{+2}$.

Uma glucoamilase produzida por um mutante de A. terreus (NA170) foi purificada e caracterizada por GHOSH e colaboradores (1991). A enzima apresentou um pH ótimo de atividade de 5,0 e permaneceu estável em pH que variaram de 3,0 a 7,0. A temperatura ótima para a atividade da enzima foi de $60^{\circ} \mathrm{C}$. Essa mesma enzima foi estável em temperaturas entre 30 e $75^{\circ} \mathrm{C}$

ALI \& HOSSAIN (1991) purificaram e caracterizaram uma glucoamilase de A.terreus. A enzima foi otimamente ativa em $\mathrm{pH}$ 4,0 e estável em pHs de 3,0 a 7,0. A temperatura ótima de atividade da enzima foi de $60^{\circ} \mathrm{C}$, permanecendo estável em temperaturas entre 40 e $60^{\circ} \mathrm{C}$. Os íons $\mathrm{Ag}^{+}$e $\mathrm{Hg}^{+2}$ inibiram a atividade da enzima, por outro lado, a presença de íons $\mathrm{Mg}^{+2}$ e $\mathrm{Ca}^{+2}$ estimularam a atividade da enzima em 15 e $7 \%$, respectivamente.

Uma $\alpha$-amilase de $A$. oryzae produzida em fermentação submersa, em meio contendo glicose como fonte de carbono, a $30^{\circ} \mathrm{C}$, foi caracterizada por CARLSEN e outros (1996). O pH ótimo para a atividade da enzima foi 6,0, e esta permaneceu estável dentro de uma faixa de 
pH entre 5,0 e 7,0. A temperatura ótima, bem como a temperatura de estabilidade não foram mencionadas.

O efeito de diferentes fontes de carbono sobre a produção de $\alpha$-amilase de Rhizopus sp foram analisadas por CRUZ e outros (1997). A enzima foi produzida por fermentação submersa, em meio de cultivo com pH inicial 5,0. A temperatura de cultivo foi de $30^{\circ} \mathrm{C}$. Foram utilizados como substratos; amido solúvel, amilose de milho, amilose de batata, amilopectina de milho, amilopectina de batata e maltose. Foi obtida a seguinte ordem decrescente na produção da enzima: amilose de milho $>$ amilose de batata $>$ amilopectina de milho $>$ amilopectina de batata $>$ amido solúvel $>$ maltose.

MOHAPATRA e colaboradores (1998) caracterizaram uma $\alpha$-amilase de Mucor sp. A enzima foi produzida em fermentação submersa, com a melhor produção ocorrendo em $\mathrm{pH}$ inicial de meio de cultivo 5,0, a $30^{\circ} \mathrm{C}$. A enzima foi otimamente ativa em $\mathrm{pH} 5,0$ e em temperatura de $60^{\circ} \mathrm{C}$. A enzima parcialmente purificada apresentou, depois de incubada a $60^{\circ} \mathrm{C}$ durante 50 minutos, $50 \%$ de atividade residual. A atividade da enzima não foi alterada na presença de $10 \mathrm{mM}$ de $\mathrm{Ca}^{+2}$ e $25 \mathrm{mM}$ de $\mathrm{Mg}^{+2}$.

GOTO e colaboradores (1998) analisaram a produção de amilases por A. fumigatus, em fermentação submersa. Neste trabalho foram avaliados os efeitos de diferentes valores de $\mathrm{pH}$ inicial e temperatura de cultivo sobre a produção das enzimas. Meios com $\mathrm{pH}$ acima de 4,0 e abaixo de 10 foram considerados viáveis para a produção das enzimas. A melhor temperatura foi de $45^{\circ} \mathrm{C}$.

JIN e colaboradores (1999) analisaram a produção de glucoamilase por A. oryzae em fermentação submersa. Um pH inicial de 4,5 foi considerado ideal para a produção de glucoamilase por esta linhagem. A melhor temperatura para a produção da enzima foi $35^{\circ} \mathrm{C}$. 
MOREIRA e colaboradores (1999) estudaram a produção e as características de $\alpha$ amilase e glucoamilase de A. tamari. Neste trabalho foram avaliadas as melhores condições para a produção das enzimas, tais como fontes de carbono, $\mathrm{pH}$ inicial de meio de cultivo, temperatura e também foram determinadas as características físico-químicas de cada enzima. Glicogênio, maltose, amido, amilose e amilopectina foram as fontes de carbono que melhor induziram a síntese das enzimas. Valores de pHs iniciais de meio de cultivo entre 4,0 e 10,0 foram considerados ideais tanto para crescimento, quanto para produção das enzimas, e a melhor temperatura de crescimento e produção foi $30^{\circ} \mathrm{C}$. Ambas enzimas apresentaram atividade máxima em pHs entre 4,5 e 6,0 e foram estáveis em pHs entre 4,0 e 7,0. As enzimas exibiram ótima atividade em temperaturas entre 50 e $60^{\circ} \mathrm{C}$ e permaneceram estáveis por mais de 10 horas a $55^{\circ} \mathrm{C}$.

Em um trabalho de isolamento de linhagens fúngicas amilolíticas, RONASZEK e colaboradores (2000) isolaram 18 espécies de T. lanuginosus com grande potencial para a produção de $\alpha$-amilase e glucoamilase. Três dessas linhagens foram selecionadas para um estudo mais detalhado de produção e de algumas propriedades dessas enzimas. A maior atividade de $\alpha$-amilase foi de $46 \mathrm{U} / \mathrm{mL}$ e a melhor produção de glucoamilase foi de $1,0 \mathrm{U} / \mathrm{mL}$. $\mathrm{O}$ melhor $\mathrm{pH}$ de atividade para $\alpha$-amilase foi 5,0 e o melhor $\mathrm{pH}$ para atividade de glucoamilase foi 4,6. A temperatura ótima de atividade para ambas enzimas foi de $70^{\circ} \mathrm{C}$. O efeito da adição de íons $\mathrm{Ca}^{+2}$ sobre a atividade de $\alpha$-amilase foi investigado, e os resultados mostraram um aumento na atividade da enzima de quase $100 \%$ quando $75 \mathrm{mM}$ do íon foi acrescentado ao meio de reação.

NGUYEN e colaboradores (2002) purificaram e caracterizaram uma $\alpha$-amilase e uma glucoamilase de T. lanuginosus ATCC 34626. As enzimas foram produzidas em fermentação submersa em 48 horas a $47^{\circ} \mathrm{C}$. A $\alpha$-amilase e a glucoamilase apresentaram um pH ótimo de 
atividade de 5,5 e 5,0, respectivamente. A temperatura ótima para a atividade de ambas as enzimas foi de $70^{\circ} \mathrm{C}$. A presença de íons $\mathrm{Zn}^{+2}$ inibiu fortemente a atividade de ambas as enzimas, e por outro lado, a presença de íons $\mathrm{Mn}^{+2}, \mathrm{Fe}^{+2}$ assim como $\mathrm{Ca}^{+2}, \mathrm{Ba}^{+2}$ ocasionou um aumento na atividade de glucoamilase e $\alpha$-amilase, respectivamente.

ELLAIAH e colaboradores (2002) otimizaram a produção de glucoamilase por Aspergillus sp A3, em fermentação sólida. Fatores como temperatura, $\mathrm{pH}$ inicial do meio, e tempo foram analisados neste trabalho. A maior produção enzimática ocorreu em $\mathrm{pH}$ inicial 5,0 em temperatura de $30^{\circ} \mathrm{C}$, em 120 horas de cultivo.

PEIXOTO e colaboradores (2003) avaliaram a produção de amilases por $R$. microsporus var. rhizopodiformis em fermentação líquida. Várias fontes de carbonos foram testadas e dentre elas, glicose, maltose, amido solúvel, farelo de trigo e bagaço de cana de açúcar demonstraram excelente capacidade para indução da síntese da amilase. A enzima caracterizada apresentou $\mathrm{pH}$ ótimo de atividade 5,0 e temperatura ótima de $60^{\circ} \mathrm{C}$. Os produtos da hidrólise enzimática do amido solúvel sugerem a presença de glucoamilase no extrato enzimático.

SONI \& GUPTA (2003) avaliaram a produção de glucoamilase por Aspergillus sp AS2 em fermentação sólida. A enzima caracterizada apresentou um pH ótimo de 6,0 e uma temperatura ótima de atividade de $50^{\circ} \mathrm{C}$. Neste trabalho também foi avaliado o efeito da ação dessa enzima na hidrólise do amido a 15\%. Essa enzima apresentou uma eficiência de $87 \%$ na sacarificação do amido.

WANDERLEY e colaboradores (2004) caracterizaram uma $\alpha$-amilase de Cryptococcus flavus. A enzima produzida em fermentação submersa a $25^{\circ} \mathrm{C}$ apresentou $\mathrm{pH}$ ótimo de atividade em 5,5 e temperatura ótima em $50^{\circ} \mathrm{C}$. A mesma permaneceu estável por 60 minutos a $50^{\circ} \mathrm{C}$, e foi inibida na presença dos íons $\mathrm{Mn}^{+2}, \mathrm{Mg}^{+2}, \mathrm{Zn}^{+2}, \mathrm{Ca}^{+2}, \mathrm{Hg}^{+2}, \mathrm{Fe}^{+2} \mathrm{e} \mathrm{Cu}^{+2}$. 
A produção de glucoamilase pelo fungo termofílico Thermomucor indicae-seudaticae, em fermentação submersa foi avaliada por KAUR \& SATYANARAYANA (2004). O melhor $\mathrm{pH}$ inicial de meio de cultivo para a produção da enzima foi 7,0 e a melhor temperatura de meio de cultivo foi $40^{\circ} \mathrm{C}$. A enzima foi capaz de hidrolisar $65 \%$ do amido depois de um período de incubação de 48 horas. A atividade enzimática foi inibida pelos íons $\mathrm{Ni}^{+2}, \mathrm{Ba}^{+2}$, $\mathrm{Mn}^{+2}, \mathrm{Zn}^{+2}, \mathrm{Hg}^{+2}$ e $\mathrm{Mg}^{+2}$, mas por outro lado foi constatado um aumento de atividade na presença dos íons $\mathrm{Ca}^{+2}, \mathrm{Ag}^{+}, \mathrm{Cu}^{+2}, \mathrm{Co}^{+2} \mathrm{e} \mathrm{Fe}^{+2}$.

SILVA e colaboradores (2005) avaliaram a produção de amilases sacarificante e dextrinizante por Rhizomucor pusillus A 13.36 em fermentação líquida. Fontes de carbono como farinha de mandioca e farelo de trigo foram testadas e demonstraram excelente capacidade para indução da síntese de ambas enzimas. As atividades dextrinizante e sacarificante caracterizadas apresentaram $\mathrm{pH}$ ótimos entre 4,0-4,5 e 5,0, respectivamente e temperatura ótima de $75^{\circ} \mathrm{C}$ para ambas. A atividade sacarificante foi inibida pelo íon cálcio enquanto que a atividade dextrinizante não sofreu alteração. Os produtos de hidrólise do amido solúvel constituíram de $66 \%$ de glicose, $19,5 \%$ maltose, 7,7\% maltotriose e 6,65 de oligossacarídeos.

HERNÁNDEZ e colaboradores (2005) avaliaram a produção de amilases por Aspergillus niger em deferentes concentrações de amido em fermentação submersa. As melhores atividades acorreram em meios de cultivo suplementados com $40 \mathrm{~g} / \mathrm{L}$ de amido. $\mathrm{O}$ $\mathrm{pH}$ e temperatura ótimos para a atividade das enzimas foram de 4,9 e $50^{\circ} \mathrm{C}$, respectivamente. As enzimas apresentaram extrema sensibilidade a temperaturas superiores a $70^{\circ} \mathrm{C}$.

MICHELIN e colaboradores (2007) purificaram e caracterizaram uma glucoamilase de Paecilomyces variotti. A enzima apresentou massa molecular de $85 \mathrm{kDa}, \mathrm{pH}$ e temperatura ótimos de atividade de 5,0 e $55^{\circ} \mathrm{C}$, respectivamente. O espectro de dicroísmo circular revelou 
que a enzima é rica em $\alpha$-helice e análise de sequenciamento de aminoácidos revelou similaridade com glucoamilase de Talaromyces emersonii.

PEIXOTO-NOGEIRA e colaboradores (2008) avaliaram a produção de glucoamilases e $\alpha$-amilases por Rhizopus microsporus var. rhizopodiformis em fermentação em estado sólido. O melhor pH inicial para a produção das enzimas foi 4,5 e a temperatura ótima de cultivo foi $45^{\circ} \mathrm{C}$. As enzimas no extrato bruto apresentaram $\mathrm{pH}$ e temperatura ótimos de atividade de $4-5$ e $65^{\circ} \mathrm{C}$, respectivamente.

ESFAHANIBOLANDBALAIE e colaboradores (2008) padronizaram as condições ótimas de cultivo para a produção de $\alpha$-amilase por Aspergillus oryzae. $\mathrm{O}$ melhor $\mathrm{pH}$ para a produção das enzimas foi 6,2 e a melhor temperatura foi de $35^{\circ} \mathrm{C}$. A presença de glicose no meio de cultivo reprimiu a produção das $\alpha$-amilases.

VARALAKSHMI e colaboradores (2009) estudaram a produção de $\alpha$-amilase por Aspergillus niger JGI 24, usando fermentação em estado líquido e estado sólido. As maiores atividades foram verificadas em meio com amido e extrato de carne como suplementos. A enzima parcialmente purificada apresentou massa molecular de $43 \mathrm{kDa}, \mathrm{pH}$ ótimo de atividade 9,5 e uma temperatura ótima de $30^{\circ} \mathrm{C}$.

\section{5- Gênero Aspergillus}

Existem cerca de 200 espécies de Aspergillus comumente isolados do solo, materiais em decomposição e do ar (WAINWRIGHT, 1995). Um grande número de enzimas extracelulares muitas das quais utilizadas em biotecnologia são produzidas por fungos desse gênero. Dentre as espécies mais conhecidas encontram-se Aspergillus niger, A. flavus, A. oryzae, A. nidulans, A. fumigatus, A. clavatus, A. glaucos, A. ustus e A. versicolor. Os Aspergilus spp. pertencem ao reino fungi, filo Ascomycota, ordem dos Eurotiales, família 
Trichocomaceae e Gênero Aspergillus. Suas colônias podem apresentar coloração branca, amarela, amarelo-esverdeado, amarronzado e verde. O gênero Aspergillus é um modelo biológico clássico e em geral tem grande relevância prática, por existirem espécies produtoras de enzimas industriais, ácidos orgânicos e outros produtos comercialmente importantes. A produção de amilases foi descrita em diferentes espécies de Aspergillus: A. terreus CTC826 (ALI \& HOSSAIN, 1991), A. tamarii (MOREIRA et al., 1999), A. niger (KOCHER et al., 2003), A. ocharaceus (NAHAS \& WALDERMARIN, 2002), A. awamori NRRL 3112. (KILIKIAN, 1996), entre outros.

\section{6 - Aspergillus niveus}

O microrganismo em estudo foi recentemente isolado em nosso laboratório a partir de Mangifera indica e identificado pela Universidade Federal de Pernambuco. Dentre os 23 fungos filamentosos testados para a produção de amilases em meio líquido, Aspergillus niveus foi o que melhor produziu as enzimas de interesse, sendo, portanto selecionado para dar continuidade ao projeto. Estudos de otimização da produção de amilases por esse fungo em meio líquido mostraram que o meio Khanna em condições físicas de cultivo estacionário, bem como $\mathrm{pH}$ inicial de meio de cultivo 6,5 e temperatura de cultivo de $40^{\circ} \mathrm{C}$, foram as condições ideais para a síntese das amilases.

Dados da literatura tem mostrado que além de amilases, A. niveus apresenta potencial para produção de outras enzimas de interesse comercial, tais como xilanases, inulinases, $\beta$ glicosidades, endoglucanases e pectinases. Uma xilanase de A. niveus foi purificada e caracterizada por ANGAYARKANNI e colaboradores (2006). A enzima apresentou um pH e temperatura ótimos de atividade 5,0 e $50^{\circ} \mathrm{C}$, respectivamente. A enzima permaneceu estável por 3 dias a $37^{\circ} \mathrm{C}$ e 30 minutos a $60^{\circ} \mathrm{C}$. Sua massa molecular determinada por SDS-PAGE e 
seu ponto isoelétrico foram estimados em $32,30 \mathrm{kDa}$ e 4,30, respectivamente. O mesmo autor e colaboradores (2002) avaliaram a produção de pectinases por esse mesmo fungo. A enzima purificada apresentou $\mathrm{pH}$ e temperatura ótimos de 6,0 e $50^{\circ} \mathrm{C}$, respectivamente. As enzimas permaneceram estáveis por 3 dias a $37^{\circ} \mathrm{C}$ e 60 minutos a $50^{\circ} \mathrm{C}$. Sua massa molecular foi determinada em SDS-PAGE e estimada em $23 \mathrm{kDa}$.

SOUZA-MOTTA e colaboradores (2005) avaliaram a produção de inulinases por $A$. niveus Blochwitz 4128 URM em meio líquido. As enzimas apresentaram pH e temperatura ótimos de atividade $4,0,4,8$ e $45^{\circ} \mathrm{C}$, respectivamente. Duas endoglucanases extracelulares e uma $\beta$-glicosidase produzidas por A. niveus foram parcialmente purificadas por TAJALDEEN \& ALKENANE (1996). As enzimas parcialmente purificadas apresentaram massas moleculares de $130 \mathrm{kDa}$ e $35 \mathrm{kDa}$, para endoglucanase I e endoglucanase II, respectivamente e $194 \mathrm{kDa}$ para $\beta$-glicosidase.

\section{7- Proteínas N-glicosiladas}

Estima-se que mais da metade das proteínas encontradas na natureza são glicosiladas, com mais de $75 \%$ destas contendo carboidratos N-ligados (APWEILER et al., 1999). A Nglicosilação é uma das mais comuns e complexa forma de modificação pós-traducional, gerando o maior nível de diversidade estrutural, e está intrinsecamente envolvida com processos celulares, tais como, o dobramento protéico (MOLINARI \& HELENIUS, 1999; SPIRO, 2004), secreção de proteínas (FIEDLER \& SIMONS, 1995), transporte intracelular (HELENIUS \& AEBI, 2004) e comunicação celular com o meio extracelular (VARKI, 1993). Em geral N-glicanas, conferem maior estabilidade às glicoproteínas (RUDD et al., 2001). Um papel estrutural para os oligossacarídeos $\mathrm{N}$-ligadoss inclui a manutenção da estrutura quaternária de uma proteína. 
A síntese e o modelamento da estrutura e função da proteína por glicosilação ligada a asparagina tem sido revisada (IMPERIALI \& RICKERT, 1995; O'CONNOR \& IMPERIALI, 1996) e o efeito da N-glicosilação na estrutura secundária da proteína, dobramento, propriedades físico-químicas, estabilização e eventos de reconhecimentos estão bem elucidados. Estudos recentes estudos têm mostrado que a N-glicosilação também pode ter um importante efeito na atividade enzimática, diminuindo sua especificidade pelo substrato. Nos últimos anos um número impressionante de estudos surgiu envolvendo a remoção sistemática de sítios de N-glicosilação de várias enzimas, objetivando descobrir o papel individual de cada N-glicana na secreção enzimática, atividade e especificidade pelo substrato.

\section{8- O-glicosilação}

Assim como as N-glicanas, outra complexa forma de modificação estrutural póstraducional é a O-glicosilação. A O-glicosilação é composta por açúcares ligados ao grupo $\beta$ hidroxil dos aminoácidos serina e treonina e seu arranjo estrutural varia de organismo para organismo, o tipo de açúcares envolvido e também a forma com que esses açúcares estão ligados entre si (GOTO, 2007). Diferentemente das N-glicanas, as O-glicanas funcionalmente são pouco conhecidas e alguns trabalhos na literatura tem mostrado haver diferentes funções para esses açúcares em diferentes organismos. O-glicanas é bem conhecido em levedura Saccharomyces cerevisae e sua estrutura é definida como uma cadeia linear contendo manoses, as quais são introduzidas na proteína a partir do retículo endoplasmático.

Apesar do pouco conhecimento da função das O-glicanas em fungos, um trabalho realizado com uma enzima de levedura demonstrou haver uma relação entre a presença desse carboidrato e o reconhecimento da enzima pelo seu substrato (GOTO, 2007). Já estudos realizados com glucoamilase de Aspergillus mostraram haver uma forte associação entre os 
domínios de ligação ao substrato, domínio catalítico e o domínio O-glicosilado (GOTO, 2007).

\section{9- Desglicosilação}

A N-glicosilação ocorre no resíduo Asparagina (ASP-N) da seqüência ASN-XaaSER/THR da proteína, onde Xaa é qualquer aminoácido exceto prolina (BAUSE, 1983). Recentes estudos estimam que 70-90\% destas seqüências são glicosiladas. N-glicanas são divididas em 3 principais tipos; como "high" manose, complexo e N-glicanas do tipo híbrido (WITTMANN, 2008). Além da notável complexidade estrutural que estas cadeias conferem as proteínas, uma complexidade adicional surge da capacidade das diferentes $\mathrm{N}$-glicanas ocuparem os mesmos locais na proteína. Esses arranjos proporcionam várias glicoformas para uma proteína, ao mesmo tempo em que cada uma pode desempenhar uma única função (RUDD \& DWEK, 1997).

Nos últimos anos têm surgido diferentes estratégias para a remoção de N-glicanas das proteínas. A desglicosilação é tipicamente alcançada utilizando interconversão sítio-dirigida da Asparagina (ASN-N) da sequiência ASN-Xaa-SER/YHR por glutamina (GLU-Q) ou outro aminoácido como a Alanina (ALA-A). A desglicosilação também pode ser alcançada pelo uso de substâncias químicas que atuam como inibidores de processamento de glicoproteínas como a tunicamicina, um antibiótico que bloqueia os primeiros passos da síntese das glicoproteínas. Outra substancia química utilizada é a castanospermina que inibe a atividade $\alpha$ e $\beta$ glucosidase no segundo passo da síntese da glicosilação. Uma terceira substancia química seria a deoxymannojirimicina que bloqueia a conversão de "high" manose para N-glicanas do tipo complexo.

A desglicosilação também pode ser feita usando desglicosilases como a PNGase F, que quebra entre o resíduo de GlcNAc e ASN de muitas N-ligações de glicoproteínas. Outro grupo 
de desglicosilases são as endoglicosidases $\mathrm{F}$ ou $\mathrm{H}$ que clivam entre os 2 resíduos de GlcNAc. Outras enzimas são as neuraminidases e $\beta$-galactosidase, que resultam em uma decoração final do complexo e N-glicanos híbridos.

\subsection{0- Tecnologia enzimática e imobilização de enzimas}

As enzimas são biocatalizadores por excelência, atuando em seqüências organizadas, catalisam centros de reações nas rotas metabólicas dos seres vivos sobre condições ótimas. Algumas propriedades das enzimas fazem com que estas sejam excelentes competidoras dos catalisadores químicos tradicionais, tais quais a grande eficiência catalítica (kcat), tendo em conta que o principal objetivo de qualquer processo de biotransformação é obter uma elevada conversão de substrato em produto a um curto espaço de tempo. Além dessa característica as enzimas apresentam uma elevada especificidade e seletividade dependendo da sua função metabólica, atuam sobre condições suaves de reação como pressão, pH e temperatura e também não proporcionam nenhum dano ao meio ambiente por tratar-se de um composto biológico que pode ser facilmente degradado.

Atualmente, são conhecidas mais de 2000 enzimas e apesar da excelente propriedade catalítica que apresentam, pouco mais de 400 são exploradas e a maioria são enzimas extracelulares e de origem microbiana. Durante o decorrer evolutivo as enzimas foram otimizadas em função do papel fisiológico que desempenham nos organismos e não em função das necessidades das indústrias. Desta forma, muitas enzimas não são suficientemente estáveis às condições de reações desejadas, tais como a agitação mecânica, os dissolventes, as altas temperaturas, $\mathrm{pH}$ extremos, a necessidade de cofatores assim como sua inibição por elevadas concentrações de substratos e produtos (KLIBANOV, 1983b). Em função dessas adversidades, a tecnologia enzimática surge como uma ferramenta importante que tem como 
objetivo superar todos os inconvenientes que impeçam a aplicação das enzimas em processos industriais.

A imobilização pode ser definida como o movimento não independente das células ou enzimas na parte aquosa do sistema, por estarem alojadas dentro ou na superfície do agente imobilizador (TAMPION \& TAMPION, 1998) e também pode ser definida como a fixação de enzimas ou células vivas em um ambiente, de maneira que sua atividade catalítica não seja afetada negativamente (CANTARELLI, 1989).

O uso da imobilização de enzimas se faz normalmente quando determinadas enzimas com interesse industrial apresentam limitações por falta de estabilidade sobre as condições exigidas para o processo, e também quando se faz necessário à recuperação e a reciclagem do biocatalisador. Uma vez imobilizado o catalisador (fisicamente confinado ou localizado em uma região definida no espaço com retenção de sua atividade catalítica) deixa de ser um catalisador solúvel e passa a apresentar algumas vantagens que só um catalisador heterogêneo possui, tais quais a possibilidade de reutilização ou o uso continuo, fácil separação da mistura de reação, possibilidade de modulação das propriedades catalíticas, prevenção de contaminação do produto com proteínas, prevenção de uma contaminação microbiana e uma possível estabilização da estrutura tridimensional da enzima.

As propriedades das enzimas imobilizadas (derivados enzimáticos) podem ser determinadas tanto por características da enzima quanto por características do suporte sobre o qual estão imobilizadas. A ligação estabelecida entre ambos dá lugar a um derivado enzimático com propriedades químicas e mecânicas especificas tal como ilustrado na Figura 4 (TISCHER \& KASCLE, 1999). A velocidade e o rendimento da imobilização são determinados por parâmetros como o tipo de suporte empregado, o método escolhido, a concentração da enzima e dos grupos reativos do suporte, $\mathrm{pH}$, temperatura e tempo de reação 
(BUCHHOLZ, 1979). Os distintos métodos de imobilização são classificados de acordo com a interação físico-química usada na união entre o suporte e a enzima. A adsorção sobre suportes iônicos e a imobilização covalente são as técnicas mais disponíveis e as que são empregadas em maior número nas indústrias (BUCHHOLZ et al., 2005).

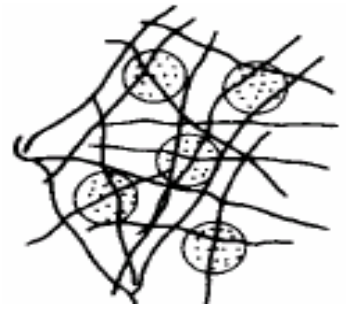

1.

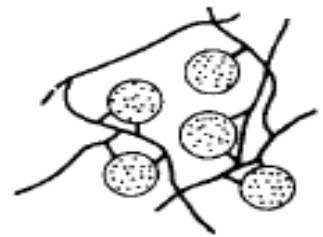

3.

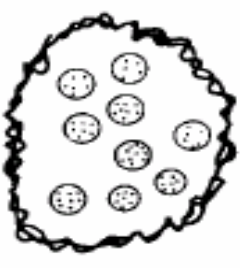

2.

Figura 4: Métodos de imobilização de enzimas. 1-aprisionamento, 2- encapsulação, 3-união covalente, 4- adsorção e 5- entrecruzamento.

\subsection{1- Imobilização irreversível por ligação covalente}

Neste método de imobilização a união entre a enzima e o suporte é irreversível uma vez que as ligações formadas são fortes e estáveis, o que impede que a enzima se libere para o meio reativo (FABER, 1996; LECKBAND \& LANGER, 1991). Para a obtenção de um elevado rendimento de imobilização é necessário que os aminoácidos essenciais para a 
catálises não estejam envolvidos na união covalente com o suporte. Uma união covalente forma-se normalmente entre os grupos funcionais presentes no suporte e as cadeias laterais dos aminoácidos disponíveis na superfície da proteína (grupos $\mathrm{NH} 2$ das Lisinas, $\mathrm{SH}$ das Cisteínas, $\mathrm{OH}$ das Tirosinas e Serinas e $\mathrm{COOH}$ dos ac. Aspártico e ac. Glutâmico) dando lugar a ligações do tipo amida, tio-ester e éter ou ligações carbamatos (SRERE \& UYEDA, 1976). A imobilização por união covalente tem permitido modificar as propriedades das enzimas imobilizadas em relação e enzima solúvel, tais como melhorias na eficiência catalítica e também na sua estabilidade frente a agentes que provocam alteração na estrutura protéica (FERNÁNDEZ-LAFUENTE et al., 1999a; GUISÁN et al., 1993).

\subsection{2- Imobilização reversível por adsorção iônica}

Neste tipo de imobilização a adsorção da proteína com o suporte é do tipo eletrostática (ligação iônica e pontes de hidrogênio) onde essas interações são débeis e abundantes o suficiente para gerar uma união estável entre a enzima e o suporte, e normalmente constitui um protocolo conveniente para a imobilização de algumas enzimas indústrias. A reversibilidade de um derivado implica na possibilidade de obtenção de uma completa desorção da enzima com a aplicação de uma força iônica alta quando a atividade do catalisador não é rentável. O suporte pode ser recuperado livre de proteínas e voltar a ser utilizado em uma posterior imobilização com uma nova enzima.

Este método de imobilização é muito apreciado em processos industriais em que o suporte representa um valor importante no custo total do catalisador. Um exemplo clássico seria o uso de DEAE celulose que tem sido empregada em escala industrial para a imobilização da glicose isomerase (ANTRIM \& AUTERINEN, 1986). 
Devido à dificuldade em manter a enzima adsorvida no suporte sobre condições de reações desejadas, este método tem sido tradicionalmente empregado para a purificação de proteínas (LYDDIATT, 2002; CHEN et al., 2003). Variações de pH, presença de substratos ou produtos ionizáveis e altas temperaturas podem acelerar a desorção das enzimas (KENNEDY et al., 1990). O desenvolvimento de matrizes mais flexíveis de grande superfície e com alta densidade de resíduos iônicos aumentaria a interação com a superfície das enzimas, possibilitando ligações mais fortes do que aquelas alcançadas com matrizes rígidas do tipo agarose dietilaminoetil (DEAE) ou agarose caboximetil (CM).

Neste trabalho, em função das considerações anteriormente abordadas, imobilizamos uma glucoamilase e uma $\alpha$-glucosidase de Aspergillus niveus em diferentes suportes com interação iônica e covalente uni e multipontuais. Aproveitamos também para avaliar o efeito protetor da trealose e dextrano sobre os derivados enzimáticos quando exposto as temperaturas elevadas. 


\section{2- OBJETIVOS}

A presente tese teve como objetivo a coleta e o isolamento de fungos filamentosos potencialmente produtores de amilases. Do fungo selecionado, A. niveus, otimizou-se a produção de amilases visando a purificação por processos cromatográficos e imobilização em suportes com interação iônica e por ligação covalente uni e multipontual. Com as amostras purificadas objetivou-se a caracterização de parâmetros físico-químicos, constantes cinéticas e propriedades intrínsecas das enzimas. Outra obordagem realizada envolveu estudos de $\mathrm{N}$ e O-glicosilação " in vivo" e suas consequiências frente a vários parâmetros físico-químicos e cinéticos. 


\section{1- Coleta e isolamento dos fungos}

Os diferentes fungos foram coletados em três regiões do Estado de São Paulo, como a Floresta Estadual de Bebedouro, termas dos Laranjais em Olímpia e silagem de milho da zona rural de Santa Rita do Oeste. As coletas foram realizadas em solo, materiais em decomposição, folhas, frutos, ou água doce, seguindo normas estabelecidas pela FAPESP. Os locais foram georreferenciado por GPS-“Global Positioning Systems” etrex, Garmin, 12 canais, onde foi determinada latitude, longitude, precisão do aparelho e altitude. Foram registradas as datas, horas e temperatura ambiente do momento de cada coleta. Para as amostras líquidas foram anotadas a condutividade $(\mu \mathrm{S} / \mathrm{cm})$, oxigênio dissolvido $(\mathrm{mg} / \mathrm{mL}), \mathrm{pH}$, turbidez (NTU), e demais informações sobre o ecossistema local, habitat e/ou microhabitat, localização geral, área ripária, sempre de acordo com a ficha padrão para coletas e registro BIOTA/FAPESP, disponível no site: http://sinbiota.cria.org.br.

Para isolamento dos fungos filamentos, a metodologia adotada foi a de plaqueamento com diluições sucessivas, onde suspensões de solo, contendo traços de pentabiótico veterinário, foram inoculadas em distintas diluições em placas de Petri contendo meio de cultura constituído por farinha de aveia $4 \%$ e agar bacteriológico $2 \%$. As placas foram incubadas em estufa bacteriológica, em temperaturas entre $35-40^{\circ} \mathrm{C}$, para crescimento preferencial de fungos termotolerantes ou termofílicos. Em seguida, foi realizado o processo de isolamento das diferentes cepas, de acordo com observação macroscópica, quanto à cor dos esporos, mudança de cor do meio de cultura provavelmente devido à formação de metabólitos secundários, e por fim a textura da colônia (liso, enrugado, hifas aéreas, etc).

\section{2- Seleção das linhagens produtoras de amilases em fermentação líquida}

Uma suspensão aquosa de conídios foi obtida junto às culturas isoladas, por raspagem da superfície da cultura com alça de platina e adição de $10 \mathrm{~mL}$ de água destilada. Parte desta 
suspensão de conídios (1mL) foi vertida em $25 \mathrm{~mL}$ de meio SR (RIZZATTI et al., 2001), tendo amido solúvel como fonte de carbono, esterilizado, contidos em frascos de $125 \mathrm{~mL}$. O material inoculado foi homogeneizado e mantido em estufa a $35^{\circ} \mathrm{C}$ por 72 horas sob agitação de 100 rpm e em condição estática.

Junto com as cepas isoladas, também participaram do screening fungos já isolados e alguns identificados até o momento no projeto Biota. Para tal seleção foram utilizadas as cepas já identificadas de Aspergillus niveus, Aspergillus ochraceus e Penicillium purpurogenum e as não identificadas, denominadas de linhagens C7B e C9A.

\section{3- Manutenção das cepas em laboratório}

A manutenção rotineira das cepas em laboratório está sendo realizada em placas de Petri estéreis contendo $25 \mathrm{~mL}$ de meio de aveia sólido. Estão sendo realizados repiques periódicos mantendo-se as cepas em estufa a $35^{\circ} \mathrm{C}$, por aproximadamente dez dias, as quais em seguida, são transferidas para geladeira, onde são conservadas. A manutenção de todo o acervo de fungos isolados também está sendo realizada em sílica gel, onde uma suspensão de esporos foi preparada em $5 \mathrm{~mL}$ de solução de leite Molico desnatado $(20 \mathrm{~g} / 100 \mathrm{~mL}$ de água destilada). Desta suspensão, aproximadamente $0,5 \mathrm{~mL}$ foram misturados a $6 \mathrm{~g}$ de sílica gel branca 1-4 mm contida em tubos de ensaio $(16 \times 100 \mathrm{~mm})$ vedados com rosca. Três tubos estão sendo armazenados para cada cultura. Todos os passos foram conduzidos de forma asséptica.

\section{4- Meios para a manutenção das cepas}

As cepas foram mantidas em meio BDA ou meio de aveia, em placas de Petri e em tubos de ensaio inclinados e mantidos sob refrigeração. 


\section{Meio BDA}

- Batata. $30 \mathrm{~g}$

- Glicose $.2,0 \mathrm{~g}$

- Agar bacteriológico $.2,0 \mathrm{~g}$

- Água destilada q.s.p. $100 \mathrm{~mL}$

As batatas foram cozidas, maceradas na própria água utilizada para o cozimento e filtradas, sendo o filtrado utilizado para a preparação do meio.

Meio de aveia

- Farinha de aveia Quaker $4,0 \mathrm{~g}$

- Agar bacteriológico $2,0 \mathrm{~g}$

- Água destilada q.s.p. $100 \mathrm{~mL}$

Os meios foram autoclavados por 15 minutos a 1,5 atm.

\section{5- Obtenção dos conídios}

Uma suspensão aquosa de conídios foi obtida junto às culturas estoques, por raspagem da superfície da cultura com alça de platina e adição de água destilada estéril. Esta suspensão de conídios foi agitada para a homogeneização e contada em câmara de Neubauer, para posteriormente ser feito o inoculo. 


\section{6- Condições de cultivo}

O processo fermentativo em meio líquido ocorreu em frascos Erlenmeyer de $125 \mathrm{~mL}$ em um volume total de $25 \mathrm{~mL}$ para os experimentos de otimização das condições de cultivo. Alguns meios líquidos foram testados, e o meio mais favorável à produção das amilases foi o Khanna (KHANNA et al., 1995) pH 6,5 a $40^{\circ} \mathrm{C}$, utilizando inicialmente amido solúvel a $0,25 \%$ e, posteriormente, milho moído e casca de mandioca a $1 \%$. O crescimento ocorreu em estufa bacteriológica durante um período de 3 dias. Os meios testados e suas composições estão descritos a seguir:

Meio Adams (ADAMS, 1990)

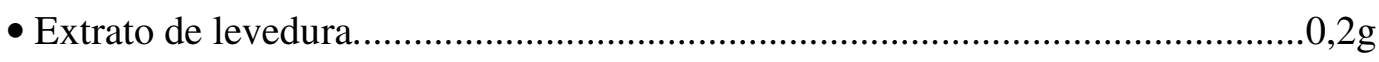

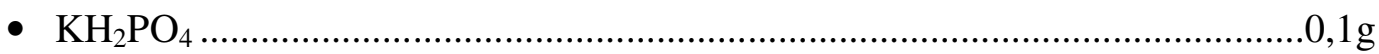

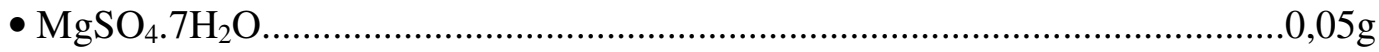

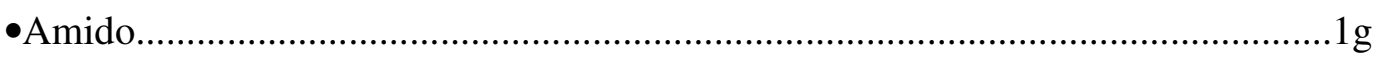

• Água destilada q.s.p ...................................................................100mL

Meio Khanna (KHANNA et al., 1995)

• Solução de sais de Khanna [20x]-.......................................................

• Extrato de levedura...................................................................................... $0,1 \mathrm{~g}$

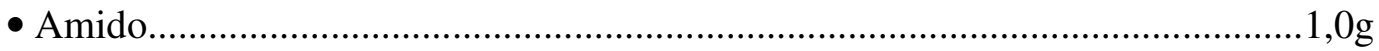

•Água destilada q.s.p..........................................................................100mL

Solução de sais de Khanna [20X]

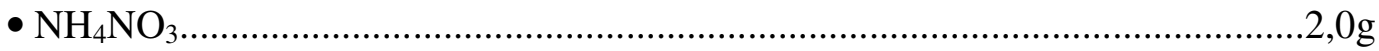


- $\mathrm{KH}_{2} \mathrm{PO}_{4}$

- $\mathrm{MgSO}_{4} \cdot 7 \mathrm{H}_{2} \mathrm{O}$ $0,362 \mathrm{~g}$

- $\mathrm{KCl}$ $.0,098 \mathrm{~g}$

- $\mathrm{ZnSO}_{4} \cdot \mathrm{H}_{2} \mathrm{O}$ $0,007 \mathrm{~g}$

- $\mathrm{MnSO}_{4} \cdot \mathrm{H}_{2} \mathrm{O}$ $0,0138 \mathrm{~g}$

- $\mathrm{Fe}_{2}\left(\mathrm{SO}_{4}\right)_{3} \cdot 6 \mathrm{H}_{2} \mathrm{O}$ $0,0066 \mathrm{~g}$

- $\mathrm{CuSO}_{4} .5 \mathrm{H}_{2} \mathrm{O}$. $0,0062 \mathrm{~g}$

- Água destilada q.s.p. $100 \mathrm{~mL}$

Meio SR (RIZZATTI et al., 2001)

- Solução de sais SR [20X]$.5,0 \mathrm{~mL}$

- Peptona $0,02 \mathrm{~g}$

- Extrato de levedura $0,45 \mathrm{~g}$

- Amido $1,0 \mathrm{~g}$

- Água destilada q.s.p. $100 \mathrm{~mL}$

Solução de sais SR [20X]

- $\mathrm{MgSO}_{4} \cdot 7 \mathrm{H}_{2} \mathrm{O}$ $.0,24 \mathrm{~g}$

- $\mathrm{KH}_{2} \mathrm{PO}_{4}$ $.0,3 \mathrm{~g}$

- $\mathrm{NH}_{4} \mathrm{H}_{2} \mathrm{PO}_{4}$ $.1,0 \mathrm{~g}$

- Água destilada q.s.p. $100 \mathrm{~mL}$

Meio Czapek (WISEMAM, 1975 ) 
- $\mathrm{NaNO}_{3}$ $.0,3 \mathrm{~g}$

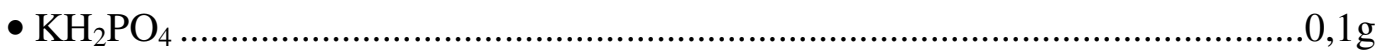

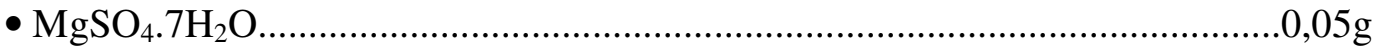

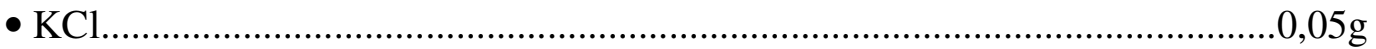

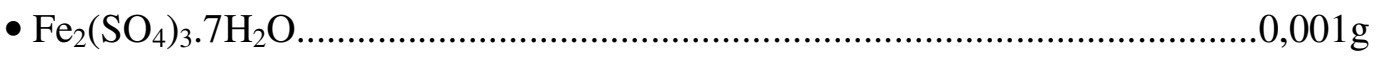

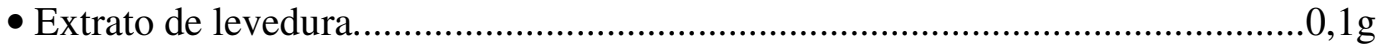

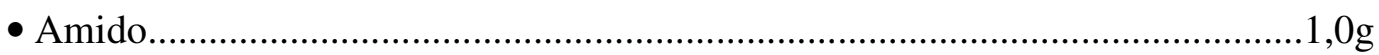

• Água destilada q.s.p.......................................................................100mL

\section{7- Obtenção do extrato bruto}

As culturas, após crescimento em condições determinadas, foram filtradas a vácuo com auxílio de um funil de Buchner e papel de filtro, onde foi obtido um filtrado de meio de cultivo livre de células e um micélio. Para os ensaios enzimáticos foi utilizado o filtrado dialisado durante uma noite a $4^{\circ} \mathrm{C}$, contra água destilada.

\section{8- Medida da atividade enzimática}

\subsection{1- Determinação da atividade enzimática utilizando ácido 3,5-dinitrosalicílico} (DNS)

A atividade amilásica foi avaliada pela determinação de açúcares redutores formados durante a incubação da enzima com amido Reagen 1\%, utilizando-se ácido $3^{\prime}, 5^{\prime}$ dinitrosalicílico, DNS (MILLER, 1959). A mistura de reação foi constituída de $250 \mu \mathrm{L}$ de amido $1 \%(\mathrm{p} / \mathrm{v})$ (dissolvido em tampão acetato de sódio $100 \mathrm{mM}, \mathrm{pH} 5,0)$ e $250 \mu \mathrm{L}$ de enzima convenientemente diluída. Após incubação desta mistura, na temperatura ótima de reação, alíquotas de $100 \mu \mathrm{L}$ foram retiradas nos tempos desejados e adicionadas em tubos contendo 
$100 \mu \mathrm{L}$ de DNS. Após a coleta de todos os pontos, estes foram aquecidos em banho fervente por 5 minutos e, após resfriamento, foi adicionado $1,0 \mathrm{~mL}$ de água destilada por tubo. A leitura da absorbância foi realizada em $540 \mathrm{~nm}$, contra um branco constituído de $50 \mu \mathrm{L}$ de enzima (inativada por $100 \mu \mathrm{L}$ de DNS) e $50 \mu \mathrm{L}$ de substrato.

Uma unidade de atividade amilásica foi definida como a quantidade de enzima necessária para produzir $1 \mu$ mol de açúcar redutor, por minuto, nas condições de ensaio, utilizando uma reta padrão obtida a partir da glicose $0,1 \%$ e a atividade específica como sendo Utotal/mg proteína total.

\subsection{2- Dosagem da atividade enzimática através da liberação de glicose (atividade} de glucoamilase) usando o Kit glicose oxidase-GOD

A determinação da atividade de glucoamilase foi realizada através do método da peroxidase-glicose oxidase (BERGMEYER \& BERNT, 1974), utilizando Kit comercial Glicose-Enz-Color (biodiagnóstic).

A mistura de reação foi constituída de $180 \mu \mathrm{L}$ de solução de amido solúvel a $1 \%(\mathrm{p} / \mathrm{v})$ em tampão acetato $0,1 \mathrm{M}, \mathrm{pH}$ 5,0 e $20 \mu \mathrm{L}$ de solução enzimática, convenientemente diluída. Após a incubação da mistura de reação a $60^{\circ} \mathrm{C}$, por 5 minutos, as amostras foram submetidas a banho fervente por 3 minutos. Foram adicionados $500 \mu \mathrm{L}$ do reagente glicose oxidase em cada tubo de ensaio, sendo estes incubados a $37^{\circ} \mathrm{C}$, por 30 minutos.

O controle foi preparado levando a mistura de reação a banho fervente por 3 minutos. A leitura de absorbância foi feita a 490nm, e os resultados expressados em $\mu$ mols de glicose/minuto/mL. 


\subsection{3- Dosagem da atividade enzimática sobre substratos sintéticos}

Além das dosagens anteriormente descritas, também foi avaliada a capacidade de ação das enzimas sobre substratos sintéticos. As misturas de reações foram compostas por $0,2 \mathrm{~mL}$ de tampão acetato de sódio a 0,1M, pH 5,0 e 0,05mL de soluções de p-nitrofenil- $\alpha$-Dglucopiranosídeo ( $\alpha$-PNPG), p-nitrofenil- $\beta$-D-glucopiranosídeo ( $\beta$-PNPG) e p-nitrofenil- $\alpha$-Dmaltosídeo a 2,0mM. Foram adicionados $0,1 \mathrm{~mL}$ de enzima a cada meio reativo e as misturas incubadas a $60^{\circ} \mathrm{C}$, por 10 minutos e em seguida interrompida com a adição de $1,0 \mathrm{~mL}$ de $\mathrm{Na}_{2} \mathrm{Co}_{3}$ a 2,0M. Um controle foi feito substituindo a enzima por volume igual de água destilada e a leitura foi realizada a $410 \mathrm{~nm}$ contra um branco constituído de água destilada. Uma unidade de atividade enzimática foi definida como a quantidade de enzima necessária para produzir $1 \mu \mathrm{mol}$ de fenolato, por minuto, nas condições de ensaio.

\section{9- Dosagem protéica}

A determinação das proteínas totais extracelulares foi realizada pelo método de LOWRY et al., (1951), utilizando soro albumina bovina como padrão (BSA). As amostras puras ou diluídas em água destilada $(200 \mu \mathrm{L})$ foram acrescidas de $1 \mathrm{~mL}$ de uma solução preparada no momento do uso, composta de carbonato de sódio $2 \%$ (p/v) em $\mathrm{NaOH} 0,1 \mathrm{~N}$, sulfato de cobre $1 \%(\mathrm{p} / \mathrm{v})$ e tartarato de sódio e potássio $1 \%(\mathrm{p} / \mathrm{v})$, na proporção de 100:1:1. Após 15 minutos, acrescentou-se 100 $\mu \mathrm{L}$ de Folin Ciocalteau em água destilada (1:1). Após 30 minutos, foi feita a leitura a $620 \mathrm{nn}$.

A unidade foi definida como sendo a quantidade em $\mathrm{mg}$ de proteína/mL de amostra. A proteína total $($ Utotal $=\mathrm{mg}$ totais, ou seja, $\mathrm{mg}$ de proteína $\mathrm{x}$ volume da amostra ressuspensa.

\subsection{0- Teste de aplicabilidade em fibras alimentares}


Para a avaliação da capacidade de hidrólise de amiláceos pelas enzimas amilolíticas contidas no extrato enzimático bruto, o equivalente a $2 \mathrm{~mL}$ de extrato enzimático $(3,6 \mathrm{U} / \mathrm{mg}$ de substrato) foi adicionado junto a $2 \mathrm{~mL}$ de tampão acetato de sódio $0,1 \mathrm{M}, \mathrm{pH} 5,0$ contendo: farelo de trigo, flocos de milho, flocos de aveia, flocos de cevada, flocos de centeio, flocos de soja, farinha de mandioca e amido solúvel como controle, todos em concentração de $1 \%$. A reação ocorreu em banho a $60^{\circ} \mathrm{C}$ durante 1 hora e os resultados foram expressados em $\mu$ mol de açúcares redutores liberados durante o ensaio. As dosagens enzimáticas foram feitas segundo descrito no item 3.8.1.

\subsection{1- Estudo do uso da casca de mandioca como fonte de carbono}

\subsection{1 - Preparo da casca da mandioca}

As raízes da mandioca utilizadas nos experimentos foram adquiridas no comercio local. A primeira etapa do preparo consistiu em separar a casca da mandioca da parte externa (película). A casca livre da película foi em seguida levada a uma estufa para secagem durante 3 dias a uma temperatura de $60^{\circ} \mathrm{C}$. A casca seca foi triturada com o auxílio de um pistilo de porcelana e em seguida utilizada como fonte de carbono para a indução da síntese das amilases.

\subsection{2- Otimização das Condições de cultivo}

Aproximadamente $10^{7}$ conídios por $\mathrm{mL}$ foram inoculados em frascos Erlenmeyer contendo $25 \mathrm{~mL}$ de meio KHANNA modificado (KHANNA et al., 1995) e 1\% de casca de mandioca. Após inoculo, os meios de cultivo foram mantidos em $\mathrm{pH}$ inicial e temperatura controlados. Para estudo do efeito do $\mathrm{pH}$ inicial de meio de cultivo, os meios tiveram seus $\mathrm{pHs}$ iniciais acertados (3,5 a 7,5). Para a análise da temperatura ótima de cultivo, os meios foram cultivados em temperatura que variaram de 25 a $50^{\circ} \mathrm{C}$. Para a determinação do melhor tempo 
de cultivo, alíquotas foram tomadas em intervalos de 24 horas durante 6 dias. A dosagem enzimática foi feita conforme descrito no item 3.8.1 e a dosagem de proteínas totais conforme descrito no item 3.9.

\subsection{2- Purificação das enzimas}

Para os ensaios de purificação $100 \mathrm{~mL}$ de extrato enzimático bruto obtido em condições ideais de cultivo foi dialisado contra água destilada por aproximadamente 20 horas, a $4^{\circ} \mathrm{C}$, e em seguida, aplicado em uma coluna de troca iônica DEAE-fractogel $(2,0$ x 7,0 cm) equilibrada em tampão Tris-HCl 10 mM, pH 7,5 com um fluxo de 100 mL/h. Foram coletadas frações de $10 \mathrm{~mL}$ por tubo para efeito de ensaio enzimático e leitura a $280 \mathrm{~nm}$. Com este procedimento 2 picos com atividade amilásica foram separados. O pico I não aderiu a resina e o pico II foi retido na DEAE-fractogel, e que posteriormente foi eluído com aplicação de um gradiente linear de $200 \mathrm{~mL}$ de $\mathrm{NaCl}(0-500 \mathrm{mM})$. As frações referentes ao pico I foram reunidas em um "pool", que foi aplicado em uma coluna cromatográfica de afinidade Concanavalina A- Sepharose $(1,2 \times 5,0 \mathrm{~cm})$ equilibrada e eluída em tampão Tris- $\mathrm{HCl}$ 10mM. A atividade amilolítica foi eluída em um gradiente linear de $50 \mathrm{~mL}$ de metil- $\alpha$-Dmanopiranosideo (0-0.5 M), em tampão Tris- $\mathrm{HCl}$, a um fluxo de $36 \mathrm{~mL} / \mathrm{h}$, sendo coletados $1 \mathrm{~mL}$ por tubo para a determinação da atividade amilásica e também leitura a $280 \mathrm{~nm}$. As frações contendo atividade enzimática foram reunidas em um "pool”, posteriormente dialisado e liofilizado para aplicação em géis de SDS-PAGE e PAGE e também estudos de caracterização.

As frações referentes ao pico II da DEAE-Fractogel foram reunidas em um "pool", posteriormente dialisado e liofilizado para aplicação em coluna cromatográfica de exclusão por massa molecular Sephacryl S-200 (2,0 X $115 \mathrm{~cm})$, equilibrada e eluída em tampão acetato de sódio $100 \mathrm{mM}$ pH 5,0. Foram coletadas frações de $1 \mathrm{~mL}$ por tubo para efeito de ensaio 
enzimático e leitura a 280nm. Com este procedimento 2 picos com atividade amilásica foram separados. As frações contendo atividade enzimática foram reunidas em 2 "pools", posteriormente liofilizados, para aplicação em géis de SDS-PAGE e PAGE, e também estudos de caracterização. Todos os procedimentos ocorreram a $4{ }^{\circ} \mathrm{C}$.

\subsection{3- Caracterização enzimática em gel de eletroforese em condições não desnaturante (PAGE)}

As eletroforeses em condições não-desnaturantes foram realizadas segundo a metodologia de DAVIS (1964), para proteínas ácidas. Os géis utilizados tinham a concentração de $5 \%$ de acrilamida e foram polimerizados em placas de vidro $(7,2 \times 10,2 \mathrm{~cm})$. As amostras foram diluídas em tampão de corrida (Tris- $\mathrm{HCl}$ 0,05 M e glicina 0,036 M, pH 8,9). Foram adicionados na amostra azul de bromofenol $0,002 \%(\mathrm{p} / \mathrm{v})$ e glicerol $10 \%(\mathrm{p} / \mathrm{v})$. Foram aplicados $20 \mu \mathrm{L}$ desta mistura no gel. As eletroforeses foram realizadas no tampão de corrida durante 2 horas sob corrente de $70 \mathrm{~mA}$ e $120 \mathrm{~V}$. Após a corrida os géis foram corados com Comassie Brilhante Blue.

\subsection{4- Determinação da atividade amilásica em gel de poliacrilamida (PAGE 6\%)}

A determinação da atividade amilásica em gel de poliacrilamida foi feita usando $30 \%$ de Bis/Acrilamida, Tris 1,0 M (pH 8,9), persulfato de amônio 10\% e TEMED. Após o término da corrida a $4^{\circ} \mathrm{C}$, os géis foram incubados em tampão acetato de sódio $500 \mathrm{mM}, \mathrm{pH}$ 5,0 por 1 hora em temperatura de $4^{\circ} \mathrm{C}$. Na etapa seguinte os géis foram imersos em uma solução de amido $1 \%$ por 2 horas a $4^{\circ} \mathrm{C}$ e depois incubados por 30 minutos a $60^{\circ} \mathrm{C}$. As revelações foram feitas usando solução de $\mathrm{I}_{2} 0,1 \%+\mathrm{KI} 1,5 \%$. 


\subsection{5- Caracterização enzimática em gel de eletroforese em condições desnaturante (SDS-} PAGE)

As eletroforeses em condições desnaturante foram realizadas em gel de poliacrilamida conforme metodologia descrita por LAEMMLI (1970). Os géis utilizados tinham a concentração de $8 \%$ de acrilamida e foram polimerizados em placas de vidro $(7,2 \times 10,2 \mathrm{~cm})$. As amostras foram preparadas na proporção de 1:1 em tampão de amostra (glicerol 20\%, SDS $4 \%$, azul de bromofenol $0002 \%$ e Tris $0,12 \mathrm{M}, \mathrm{pH}$ 6,75) e aquecidas durante 3 minutos em água fervente. As eletroforeses foram realizadas em tampão composto por Tris $0,025 \mathrm{M}$, glicina 0,19 M e SDS 0,1\%. pH 8,3, durante 2 horas sob corrente de 70 mA e 120 V. Após a corrida os géis foram corados com Comassie Brilhante Blue. Os padrões foram adquiridos da Pharmalite.

\subsection{6 -Determinação da massa molecular por cromatografia de filtração em gel}

A cromatografia de filtração em gel foi realizada em HPLC equipado com coluna de Bio-sil SEC-400 (30 x 0,78 cm), equilibrada e eluída com tampão HEPES 100 mM, pH 7,0, contendo $\mathrm{NaCl} 150 \mathrm{mM}$ e azida sódica $10 \mathrm{mM}$, sob o fluxo de $1,0 \mathrm{~mL} / \mathrm{min}$. Frações de $1 \mathrm{ml}$ foram coletadas automaticamente e a atividade amilásica avaliada individualmente. Para calibração da coluna foram utilizados os seguintes padrões de massa molecular: globulina (325 $\mathrm{kDa})$, imunoglobulina (158 kDa), ovoalbumina (45 kDa) e mioglobina (17 kDa). As amostras foram previamente dissolvidas em $0,02 \mathrm{ml}$ do tampão de eluição e cromatografadas separadamente na coluna por injeção manual.

\subsection{7- Caracterização físico-química das amilases purificadas}


Depois das etapas de purificação e verificação de pureza das enzimas, as mesmas foram submetidas a caracterização quanto ao $\mathrm{pH}$ e temperatura ótimos de atividade e estabilidade sob variações de $\mathrm{pH}$ e temperatura em ausência de substrato.

\subsection{1- Efeito do pH e temperatura sobre a atividade das enzimas}

Para esses ensaios foi utilizada solução tampão Mcllvaine na faixa de pH de 3,0 a 8,0. Para a determinação da temperatura ótima, as misturas de reação foram incubadas em temperaturas de 50 a $80^{\circ} \mathrm{C}$ e a dosagem enzimática seguiu como descrito no item 3.8.1.

\subsection{2- Efeito do pH sobre a estabilidade das enzimas em ausência de substrato}

Para este estudo foi utilizado tampão citrato-fosfato na faixa de $\mathrm{pH}$ de 3,0 a 8,0. Uma alíquota de $0,5 \mathrm{~mL}$ da enzima foi misturada a $0,5 \mathrm{~mL}$ da solução tampão $0,2 \mathrm{M}$, nos diferentes pH. A mistura foi incubada, em tubos de rosca, em estufa B.O.D., por 24 horas, a $25^{\circ} \mathrm{C}$. Após esse período, as atividades residuais foram determinadas nos $\mathrm{pH}$ e temperatura ótima da enzima.

\subsection{3- Termoestabilidade}

A termoestabilidade foi determinada medindo-se a atividade residual da enzima. Alíquotas foram retiradas diferentes tempos de incubação em banho maria a $60^{\circ} \mathrm{C}$ para a dosagem enzimática conforme descrito no item 3.8.1, em pH e temperatura ótimos da enzima.

\subsection{4- Efeito de íons sobre a atividade enzimática}

Para o estudo do efeito de íons sobre a atividade da amilase purificada, utilizou-se de soluções de $\mathrm{MgCl}_{2} \cdot 6 \mathrm{H}_{2} \mathrm{O}, \mathrm{MnCl}_{2} \cdot 4 \mathrm{H}_{2} \mathrm{O}, \mathrm{NaBr}, \mathrm{CuCl}_{2}, \mathrm{ZnCl}_{2}, \mathrm{BaCl}_{2}, \mathrm{NaCl}, \mathrm{HgCl}_{2}$, $\mathrm{CoCl}_{2} \cdot 6 \mathrm{H}_{2} \mathrm{O}, \quad \mathrm{NaH}_{2} \mathrm{PO}_{4} \cdot \mathrm{H}_{2} \mathrm{O}, \quad \mathrm{NH}_{4} \mathrm{Cl}, \quad \mathrm{AgNO}_{3}, \quad \mathrm{Fe}_{2}(\mathrm{SO} 4), \mathrm{CaCl}_{2}, \quad \mathrm{KCl}, \quad \mathrm{NH}_{4} \mathrm{~F}$, 
$\mathrm{Pb}\left(\mathrm{C}_{2} \mathrm{H}_{3} \mathrm{O}_{2}\right)_{2} .3 \mathrm{H}_{2} \mathrm{O}, \mathrm{KH}_{2} \mathrm{PO}_{4}$, EDTA e $\beta$-mercaptoetanol, de modo a se obter concentrações finais de 1,0 e $10 \mathrm{mM}$ do composto correspondente na mistura de reação.

\subsection{5- Efeito da adição de solventes orgânicos sobre a atividade das enzimas}

O efeito da adição de solventes orgânicos na atividade enzimática foram feitos utilizando concentrações de 5 e $10 \%$ (v/v), de solventes junto a mistura de reação. Os solventes utilizados foram: acetato de etila, álcool n-butílico, álcool isopropílico, etanol, formol, metanol, tolueno, benzeno, acetona e hexano. As dosagens enzimáticas foram feitas de acordo com o item 3.8.1.

\subsection{6- Hidrólise de diferentes substratos pelas amilases purificadas}

Para a hidrólise dos diferentes substratos foi utilizado tampão acetato de sódio $0,1 \mathrm{M}$, pH 5,0 contendo os seguintes substratos: amido solúvel Reagen, amido solúvel sigma, amilose, amilopectina, maltose, maltotriose, glicogênio, sacarose, trealose, celobiose, $\alpha$ ciclodextrina e $\beta$-ciclodextrina, e os substratos sintéticos $\alpha$-pNPG, $\beta$-pNPG, $\alpha$-D-maltosídeo e p-Nitrofenil- $\beta$-pentaosídeo. As dosagens enzimáticas foram feitas segundo descrito no item 3.8.2 e 3.8.3.

\subsection{7- Cromatografia em camada delgada de sílica (TLC) dos produtos de}

\section{hidrólise do amido}

A análise dos produtos de hidrólise, formados a partir da ação da amilases sobre o amido solúvel, foi obtida por cromatografia ascendente em camada delgada de sílica $10 \mathrm{x}$ 
20cm (DC-Alufolien Kieselgel 60 sem indicador fluorescente, Merck). A reação ocorreu pela mistura de $250 \mu \mathrm{L}$ de extrato enzimático com $250 \mu \mathrm{L}$ de substrato (amido $1 \%$ em tampão acetato de sódio $100 \mathrm{mM}, \mathrm{pH} 5,0)$. As incubações das misturas foram realizadas a $60^{\circ} \mathrm{C}$. Alíquotas foram retiradas nos tempos desejados e fervidas durante 3 minutos, em seguida, um volume de $10 \mu \mathrm{L}$ foi aplicado nas placas de sílica. Padrões de $10 \mu \mathrm{L}$ de solução de glicose, maltose e maltotriose, maltotetraose e maltopentaose, a $0,1 \%(\mathrm{p} / \mathrm{v})$, também foram aplicados. A corrida foi desenvolvida duas vezes com uma mistura de n-butanol, etanol e água destilada na proporção de 5:3:2. A revelação dos produtos de hidrólise foi realizada utilizando uma solução de $0,2 \%$ de orcinol (p/v) em metanol e ácido sulfúrico na proporção de 9:1. Posteriormente, as placas foram colocadas em estufa bacteriológica a $100^{\circ} \mathrm{C}$ até o aparecimento das bandas correspondentes aos produtos da degradação do amido.

\subsection{8- Determinação do conteúdo de carboidrato e do ponto isoelétrico (pI)}

O conteúdo de carboidratos da amilase purificada foram estimado através da metodologia do fenol-sulfúrico descrita por DUBOIS et al. (1956). Esse experimento foi realizado da seguinte maneira: adicionou-se $1 \mathrm{~mL}$ de ácido sulfúrico concentrado em uma mistura composta por $400 \mu \mathrm{L}$ da enzima mais $10 \mu \mathrm{L}$ de fenol $80 \%(\mathrm{v} / \mathrm{v})$. Essa mistura foi agitada e colocada em gelo por 10 minutos e posteriormente, incubada a $30^{\circ} \mathrm{C}$. Percorridos 15 minutos, a mistura foi novamente agitada e procedeu-se a leitura a $490 \mathrm{~nm}$. Foi feito um branco, onde a enzima foi substituída por água destilada. Para determinação da porcentagem de carboidratos utilizou-se uma curva de manose $(0-0,4 \mathrm{mg} / \mathrm{mL})$ como padrão.

O ponto isoelétrico da enzima foi determinado em gel de disco de poliacrilamida, de acordo com a metodologia proposta por O'FARREL et al. (1983), utilizando anfólitos com pHs 3,0-10,0. Após a corrida, o gel contendo a amostra foi fatiado, incubado em tampão acetato de sódio $100 \mathrm{mM}$, pH 5,0 por 1 hora. Neste período foram realizadas 3 trocas do 
tampão. Finalmente, dosou-se a atividade amilásica, conforme descrito no item 8.1, nos tubos contendo as fatias. $\mathrm{O}$ gel controle foi fatiado e incubado "overnight" em uma solução de $\mathrm{KCl}$ $25 \mathrm{mM}$, para posterior determinação do pH. Finalmente, avaliou-se qual fatia do gel controle era correspondente com a maior atividade amilásica obtida.

\subsection{9- Determinação das constantes cinéticas}

As constantes cinéticas $\left(\mathrm{K}_{\mathrm{m}}\right.$ e $\left.\mathrm{V}_{\text {máx }}\right)$ da amilase purificada foram analisadas conforme os procedimentos gráficos propostos por HANES (1932) utilizando-se o programa Enzyplot (LEONE et al., 19895). Os substratos utilizados foram amido solúvel Reagen para a glucoamilase, amido, maltose, glicogênio, amilose e $\alpha$-PNPG (3-12 mM) para $\alpha$-glucosidase, e amido para a $\alpha$-amilase nas concentrações de 3,0- 300mg/mL. A atividade amilásica foi determinada conforme metodologia descrita nos itens 3.8.1, 3.8.2 e 3.8.3.

\subsection{0- Dicroismo circular}

Para análise da estrutura secundária das amilases em estudo através de Dicroísmo circular utilizou-se o espectropolarímetro Jasco 810 (JASCO Inc., Tokyo, Japan), em comprimento de onda de 250 a $180 \mathrm{~nm}$ (UV distante), utilizando-se uma cubeta de quartzo de caminho óptico de $0,1 \mathrm{~mm}$, com uma concentração protéica de aproximadamente $0,8 \mathrm{mg} / \mathrm{mL}$ para as amilases purificadas, sendo todas as medidas feitas com uma média de nove repetições coletadas e subtraídas do branco (tampão acetato de sódio $100 \mathrm{mM}, \mathrm{pH}$ 5,5, adicionado de 150 mM de cloreto de sódio).

Em relação às $\alpha$-hélices e as folhas $\beta$, estas estruturas secundárias apresentam um espectro de CD característico na região do UV distante $(250$ - 180 nm). Assim, em proteínas 
com suas formas estruturais nativas, a composição dos elementos de estrutura secundária é altamente definida, resultando em espectros de CD com sinais característicos.

\subsection{1- Sequenciamento da Glucoamilase}

A sequiência de aminoácidos trípticos da glucoamilase purificada foi desenvolvida usando seqüenciador automático PPSQ/23 Shimadzu Corporation (Tokyo-Japan), com sistema isocrático HPLC. As informações obtidas serviram de base para comparação com glucoamilases de outras espécies do gênero Aspergillus.

\subsection{1-1 Espectrometria de Massa MALDI-TOF}

Um microlitro da amostra foi aplicada sobre os discos da placa do MALDI, contendo 1,0 mL de ácido $\alpha$-ciano-4-hidroxi-cinâmico $(5,0 \mathrm{mg} / \mathrm{mL})$ em mistura 1:1 (v/v) de acetonitrila $50 \%$ e TFA 0,05\%. Após a secagem (15 minutos em fluxo laminar), a amostra foi submetida a análises por espectrometria de massa (VIDAKOVICS et al., 2007), através do aparelho Relex IV MALDI-TOF MS (Bruker Daltonics, Karlsruhe, Germany), no modo refletor e calibrado internamente com os picos conhecidos de autólise da tripsina.

\subsection{2- Sequenciamento das $\alpha$-glucoasidases I e II}

\subsection{1- Digestão com tripsina e extração de peptídeos do gel}

Digestão 'in situ' da $\alpha$-glucosidase I e II foi realizado conforme descrito por NEUHOFF (1988). A banda de interesse do gel foi cortada e lavada 4 vezes com solução de $\mathrm{NH}_{4} \mathrm{HCO}_{3} 50 \mathrm{mM}$ e acetronitrila (ACN) $50 \%$ para a remoção de SDS e corante, sendo em seguida realizada uma lavagem com ACN. A banda completamente seca em SpeedVac foi rehidratada com $20 \mu \mathrm{L}$ de uma solução contendo $0,5 \mu \mathrm{g}$ de tripsina em solução $\mathrm{NH}_{4} \mathrm{HCO}_{3}$ 
50mM. Após rehidratação da banda por cerca de 30 minutos, adicionou-se $50 \mu \mathrm{L}$ de $\mathrm{NH}_{4} \mathrm{HCO}_{3} 50 \mathrm{mM}$ ou volume suficiente para cobrir o gel. A reação foi mantida a $37^{\circ} \mathrm{C}$ por 24 horas. Para interromper a reação foi adicionado $2 \mu \mathrm{L}$ de ácido fórmico. A extração dos peptídeos foi realizada pela adição de $40 \mu \mathrm{L}$ de $\mathrm{ACN} 60 \%$ ácido fórmico 5\%, mantida em temperatura ambiente por 3 horas; procedimento que foi repetido, sendo os sobrenadantes combinados. Estes foram concentrados em SpeedVac até aproximadamente $5 \mu \mathrm{L}$ e ressuspendidos em solução de ácido fórmico $2 \%$ e preparados por dessalificação em microtips contendo resina R2 POROS (Perseptive Biosystem). A amostra eluída em 60\% de metanol e 5\% de ácido fórmico foi analisada por espectrômetro de massa triplo-quadrupolo.

\subsection{2- Espectrometria de Massas triplo quadrupolo}

A $\alpha$-glucosidase foi caracterizada pela abordagem de "peptide mass fingerprint" (PMF) e por sequienciamento de peptídeos por dissociação induzida por colisão (CID-MS/MS) em espectrômetro de massa do tipo triplo quadrupolo com ionização por "eletrospray" modelo Quatro II-Micromass (ESI-MS/MS) do Centro de Química de Proteínas (FMRP-USP), por infusão direta com seringa Harvard (300 $\eta \mathrm{L} / \mathrm{min})$ com voltagem capilar de $3.5 \mathrm{kV}$, tensão do cone de $40 \mathrm{~V}$, e temperatura do cone de $100^{\circ} \mathrm{C}$. A aquisição de dados obtidos por CID-MS/MS foram analisadas pelo programa MASCOT (http;//matrixscience.com) com pesquisa no banco de dados de proteínas do NCBInr.

\subsection{3- Estudo do efeito das $\mathrm{N}$-glicanas nas amilases purificadas}

\subsection{1- Condição de cultivo}

Para os experimentos de indução da síntese das enzimas, a massa micelial do microrganismo crescido em 48 horas de cultivo, foi lavada em tampão acetato de sódio $50 \mathrm{mM}$ a pH 6,0, e em seguida vertidos em meio de cultivo Khanna modificado, suplementado com $1 \%$ de amido, e com a presença de tunicamicina $1 \mathrm{mg} / \mathrm{mL}$ solubilizada em $\mathrm{NaOH} 20 \mathrm{mM}$. Um 
frasco contendo apenas $\mathrm{NaOH} 20 \mathrm{mM}$ foi tomado como controle e a obtenção do extrato bruto seguiu conforme descrito no item 3.7.

\subsubsection{Purificação das amilases desglicosiladas}

Para a purificação das enzimas desglicosiladas o extrato enzimático bruto foi aplicado em coluna DEAE-Fractogel TSK 650M $(2.0 \times 7.0 \mathrm{~cm})$ previamente equilibrada em tampão Tris-HCl 10 mM, pH 7,5, e eluída a um fluxo de 100 mL/h. Frações de 10 mL foram coletadas para dosagem enzimática e os frascos contendo atividade foram reunidos em um único pool, liofilizados e aplicados em coluna de gel filtração Sephacryl S-200 gel $(2.0$ x 85 cm) equilibrada e eluída com tampão acetato de sódio 100 mM, pH 5,0. Frações de 1mL foram coletadas para medida da atividade enzimática e leitura de proteínas. As frações contendo atividade foram tomadas e usadas para a caracterização físico-química.

\subsection{4- Imobilização da glucoamilase e $\alpha$-glucoasidase II}

Glucoamilase e $\alpha$-glucosidase II foram as enzimas utilizadas nos ensaios de imobilização. Para a obtenção das enzimas, A. niveus foi inoculado em meio Khanna modificado, por 72 horas a $40^{\circ} \mathrm{C}$. O extrato enzimático bruto livre de micélio foi eluído em suporte de interação por troca iônica Glioxil-PEI, na proporção de $1 \mathrm{~g}$ de suporte para cada 10 $\mathrm{mL}$ de extrato enzimático. A glucoamilase não interagiu com o suporte enquanto que a $\alpha$ glucosidase II interagiu, e depois foi desorvida com $\mathrm{NaCl}$ 0,3 M. Para a dosagem da atividade de glucoamilase foi utilizado amido solúvel Sigma e para a dosagem da $\alpha$-glucosidase foi utilizado p-nitrofenil- $\alpha$-D-glucopiranosídeo ( $\alpha$-pNPG). Essa etapa do trabalho foi toda desenvolvida no laboratório de Engenharia Enzimática do Departamento de Biocatálises, 
Instituto de Catálises e Petroleoquímica, Universidade Autônoma de Madri, Espanha, sob a supervisão do Doutor Benevides Costa Pessela João e do Doutor Jose Manuel Guisan Seijas.

\subsection{5- Preparo de suportes}

\subsubsection{Preparo de suportes para imobilização reversível}

\subsubsection{1-Suporte Glioxil-agarose}

O protocolo de preparo seguiu conforme descrito por GUISAN (1988). O gel glioxilagarose com um grau de ativação de $75 \mathrm{mM}$ de grupos gliceril/ml de suporte foi preparada a partir de agarosa comercial 4BCL contendo $15 \mu$ mols de diols oxidáveis por grama de resina. Neste procedimento um volume de $150 \mathrm{~mL}$ do gel agarosa foi suspenso em $30 \mathrm{~mL}$ de água e $50 \mathrm{~mL}$ de $\mathrm{NaOH}$ 1,7 N contendo $28,5 \mathrm{mg} / \mathrm{mL}$ de borohidreto de sódio. Sobre essa solução adicionou-se lentamente $2 \mathrm{M}$ de glicidol, e essa mistura foi mantida sob agitação constante por 18 horas. O passo seguinte consistiu na lavagem do gel com água destilada abundante e em seguida a oxidação do gel agarose com a adição de periodato de sódio $(112 \mathrm{~mL}$ a $0.1 \mathrm{M})$ sob agitação constante a $25^{\circ} \mathrm{C}$ por 2 horas. Para finalizar o processo o gel foi novamente lavado com água destilada abundante e posterior armazenamento a $4^{\circ} \mathrm{C}$.

\subsubsection{2-Glioxil-PEI}

Os suportes agarose recobertos com polietilenimina foram preparados a partir de agarose 4BCL como descrito por MATEO et al., 2000b. Neste procedimento $9 \mathrm{ml}$ de uma solução de polietilenimina $10 \%$ preparada em bicarbonato $0.1 \mathrm{M} \mathrm{pH} 11.0$ foi adicionada a $1 \mathrm{~g}$ de gel glioxil-agarose. Essa mistura foi mantida sob agitação constante durante 3 horas a $25^{\circ} \mathrm{C}$. Por último o gel foi lavado com abundante água destilada e armazenado a $4^{\circ} \mathrm{C}$.

\subsubsection{3-Glioxil-amino (MANAE)}


Gioxil-amino (MANAE) foi preparado conforme descrito por FERNÁNDEZLAFUENTE et al. (1993). Um volume de 27,07 $\mathrm{mL}$ de etilenodiamina $2 \mathrm{M}$ foi dissolvido em $100 \mathrm{~mL}$ água destilada e em seguida o $\mathrm{pH}$ da solução foi corrigido para 10 usando $\mathrm{HCl}$ e o volume acertado para $200 \mathrm{~mL}$ com água destilada. O passo seguinte consistiu em verter a solução de etilenodiamina sobre $35 \mathrm{~g}$ de glioxil-agarose e esta deixada sobre agitação constante por 2 horas. Em seguida $2 \mathrm{~g}$ de Borohidreto de sódio $\left(\mathrm{BH}_{4} \mathrm{Na}\right)$ foram adicionados ao recipiente e este foi deixado sobre agitação por 2 horas. O passo final consistiu em lavar o gel com 1L de tampão acetato de sódio 100 mM pH 4,0 e 1L de solução de borato de sódio 100 $\mathrm{mM}, \mathrm{pH} 9,0$.

\subsubsection{4- Sepharose-Q e DEAE-Sephacel}

Uma quantia 5g de suportes Sepharose Q e DEAE-Sephacel foram adicionados em 100 $\mathrm{mL}$ de água destilada e depois de 12 horas lavados exaustivamente com água destilada para total remoção de conservantes. Por fim, os suportes foram lavados com tampão fosfato de sódio $5 \mathrm{mM}$ a pH 7,0 para posterior uso na imobilização das amilases.

\subsection{2- Preparo de suportes para imobilização irreversível}

\subsubsection{1- Agarose ativada com BrCN}

A quantia de $1 \mathrm{~g}$ de agarose 4B ativada com brometo de Cianogênio (Amersham Biosciences) foi hidratada com $50 \mathrm{~mL}$ de água destilada em $\mathrm{pH}$ 2,0, por 1 hora, sob agitação constante conforme indicação do fabricante.

\subsection{6- Protocolos de imobilização}


Em todos os casos o curso de imobilização foi controlado pela medida de atividade enzimática do sobrenadante em diferentes tempos. As suspensões (suporte + enzima) foram preparadas exatamente com a mesma concentração de enzimas e condições de meios como $\mathrm{pH}$, temperatura e força iônica. A atividade enzimática da suspensão foi tomada como controle e a diminuição da atividade do sobrenadante foi diretamente relacionada com a quantidade de enzima imobilizada no suporte.

\subsection{7- Imobilização reversível por adsorção a trocadores iônicos}

Como procedimento geral, foram adicionados $10 \mathrm{~mL}$ de solução enzimática em $1 \mathrm{~g}$ de suporte (DEAE-Sephacel, sepharose Q, glioxil-amino-MANAE e glioxil-PEI) na presença de tampão fosfato de sódio $5 \mathrm{mM} \mathrm{em} \mathrm{pH} \mathrm{7,0,} \mathrm{a} 25^{\circ} \mathrm{C}$, sob agitação constante (agitador de rolos). Durante o processo de adsorção, alíquotas da suspensão e do sobrenadante foram tomadas para medida de atividade enzimática.

\subsection{8- Imobilização irreversível por união covalente}

\subsection{1- Imobilização sobre agarose ativada com $\mathrm{BrCN}$}

Ao suporte comercial previamente ativado $(1 \mathrm{~g}) \mathrm{com} \mathrm{HCl}$ em $\mathrm{pH} 2$, foram adicionados $10 \mathrm{~mL}$ de solução enzimática de glucoamilase e de $\alpha$-glucosidase de A. niveus em tampão fosfato de sódio $5 \mathrm{mM}, \mathrm{pH}$ 7,0. Após 30 minutos sob agitação constante em agitador de rolo, uma alíquota do sobrenadante foi tomada para dosagem da atividade enzimática. Ao término do processo de imobilização, o derivado foi filtrado e posteriormente os grupos $\mathrm{BrCN}$ remanescentes foram bloqueados durante 3 horas com a adição de uma solução de 
etanolamina $1 \mathrm{M}$ em $\mathrm{pH} 8,0$. Finalmente, o derivado foi filtrado e posteriormente lavado com abundante água destilada.

\subsection{2- Imobilização sobre suporte Glioxil-agarose}

O protocolo de imobilização foi feito conforme descrito por BLANCO et al. (1989). A $1 \mathrm{~g}$ de suporte foram adicionados $10 \mathrm{~mL}$ de solução enzimática na presença de tampão bicarbonato de sódio $100 \mathrm{mM}$ a pH 10,5. Essa mistura foi mantida em agitador de rolos e a diferentes intervalos de tempos alíquotas do sobrenadante foram tomadas para a dosagem enzimática. Uma vez imobilizadas, todas as ligações formadas entre os grupos glioxil e os grupos aminos $\left(\mathrm{NH}_{2}\right.$ das lisinas) das enzimas imobilizadas foram reduzidas mediante adição de $1 \mathrm{mg} / \mathrm{mL}$ de borohidreto de sódio. Essa suspensão foi mantida sob agitação durante 30 minutos a temperatura ambiente e depois o derivado foi lavado com água destilada abundante.

\subsection{9- Medida da atividade enzimática dos derivados}

A atividade enzimática do derivado foi determinada por ensaio indireto a $25^{\circ} \mathrm{C}$, detectando a glicose liberada a partir da hidrólise do amido 1\% em tampão citrato de sódio 50mM, pH 6,5. A glicose liberada foi determinada espectrofotometricamente pelo aumento da absorbância a $405 \mathrm{~nm}$, resultante da oxidação do ABTS através de um sistema glicose oxidase e peroxidase acoplado (na presença de oxigênio e glicose oxidase a glicose é convertida em ácido glicônico, liberando peróxido de oxigênio. Este é transferido para o ABTS, pela ação da peroxidase, produzindo cor). O sistema reacional consistia de uma mistura de $0,5 \mathrm{~mL}$ de glicose oxidase 2,5 g/L, 0,5 mL de peroxidase 2,5 g/L, ambas em tampão fosfato de sódio 50 mM, pH 7, 0,4 mL de ABTS 1 mM em tampão fosfato de sódio 50 mM, pH 6 e 1,0 mL de 
amido $1 \%$ em tampão citrato de sódio $50 \mathrm{mM}, \mathrm{pH}$ 6,5. A reação era iniciada pela adição de um volume adequado de derivado enzimático $(25$ a $200 \mu \mathrm{L})$ apropriadamente diluído, e a atividade determinada tomando-se a inclinação da região linear da curva (absorbância versus tempo).

\subsection{0-Estudo da estabilidade dos derivados}

A estabilidade foi expressa como o declínio da atividade enzimática de cada derivado enzimático nas condições de incubação. O fator de estabilização foi determinando comparando as atividades residuais do derivado e da enzima livre. Os diferentes derivados enzimáticos foram incubados em diferentes temperaturas e condições de $\mathrm{pH}$, força iônica e concentração, que são detalhados nas legendas das figuras. Foram tomadas periodicamente amostras da suspensão para a medida da atividade enzimática.

\subsection{1- Reprodutibilidade}

Todos os experimentos foram realizados em triplicatas. 


\section{1- Coleta e isolamento dos fungos}

A coleta e isolamento dos fungos ocorreram como descrito no item 1 de Material e métodos e os resultados são mostrados na Tabela 1. Foram isolados 19 fungos nas três coletas realizadas. Destes, 12 foram isolados de material coletado em diferentes pontos da Fazenda Estadual de Bebedouro, 4 isolados de materiais coletados no Termas dos Laranjais em Olímpia e 3 foram isolados de silagem de milho da zona rural da cidade de Santa Rita do Oeste.

Nas amostras de águas coletadas no Termas dos Laranjais não foi isolado nenhum fungo, embora a presença dos mesmos nesse ambiente seria possível no caso de lixiviação de esporos provenientes dos solos adjacentes. 
Tabela 1: Coleta e isolamento dos fungos.

\begin{tabular}{|c|c|c|c|c|c|c|c|c|}
\hline $\mathbf{N}^{\circ}$ & Local & $\begin{array}{l}\text { Ecossistema/Posição na } \\
\text { floresta* }\end{array}$ & $\begin{array}{l}\mathrm{T} . \\
\left({ }^{\circ} \mathrm{C}\right)\end{array}$ & $\begin{array}{l}\text { Precisão } \\
\text { GPS (m) }\end{array}$ & $\begin{array}{l}\text { Altitude } \\
\text { (m) }\end{array}$ & $\begin{array}{c}\text { Latitude } \\
\quad\left({ }^{\circ}\right)\end{array}$ & $\begin{array}{c}\text { Longitude } \\
\left({ }^{\circ}\right)\end{array}$ & $\begin{array}{l}\text { Fungo } \\
\text { isolado }\end{array}$ \\
\hline 01 & $\begin{array}{l}\text { Floresta Est. } \\
\text { Bebedouro }\end{array}$ & $\begin{array}{l}\text { Espécies nativas- } \\
\text { serrapilheira }\end{array}$ & 27 & 04 & 552 & $20^{\circ} 57.433^{-}$ & $48^{0} 27.938^{-}$ & $\begin{array}{l}\text { 1.2branco } \\
\text { esverdeado } \\
1.3 \text { branco } \\
\text { aveludado }\end{array}$ \\
\hline 02 & Floresta & $\begin{array}{l}\text { Plantação de Pinus vegetação } \\
\text { rasteira }\end{array}$ & 32 & 04 & 564 & $20^{0} 57.437^{-}$ & $48^{0} 27.537$ & $\begin{array}{l}\text { 1.4amarelo } \\
2.1 \text { verde } \\
\text { escuro }\end{array}$ \\
\hline 03 & Floresta & Eucaliptos sp & 28 & 04 & 559 & $20^{0} 57.516^{\circ}$ & $48^{0} 27.585^{-}$ & $\begin{array}{l}3.1 \text { verde } \\
\text { claro }\end{array}$ \\
\hline 04A & Floresta & Pinus sp & 29 & 04 & 613 & $20^{0} 57.488^{-}$ & $48^{0} 27.704$ & $\begin{array}{l}3.2 \text { marrom } \\
4.1 \text { marrom } \\
\text { claro }\end{array}$ \\
\hline 04B & Floresta & $\begin{array}{l}\text { Área de campo - Esterco } \\
\text { bovino }\end{array}$ & 29 & 04 & 613 & $20^{0} 57.488^{-}$ & $48^{0} 27.704^{-}$ & 4.2 branco \\
\hline 05 & Floresta & Espécies nativas & 28 & 04 & 560 & $20^{0} 57.651^{`}$ & $48^{0} 27.627^{-}$ & $\begin{array}{l}5.1 \text { Verde- } \\
\text { azulado }\end{array}$ \\
\hline 06 & Floresta & $\begin{array}{l}\text { Área de campo - Esterco } \\
\text { equino }\end{array}$ & 29 & 04 & 567 & $20^{0} 57.564$ & $48^{0} 27.814^{-}$ & $\begin{array}{l}5.2 \text { violeta } \\
6.1 \text { marrom }\end{array}$ \\
\hline 07 & $\begin{array}{l}\text { Termas } \\
\text { (Olímpia) }\end{array}$ & Reservatório água - solo & 32 & 08 & 469 & $20^{0} 43.262$ & $48^{0} 55.059^{-}$ & $\begin{array}{l}7.1 \text { verde } \\
\text { escuro }\end{array}$ \\
\hline 08 & $\begin{array}{l}\text { Termas } \\
\text { (Olímpia) }\end{array}$ & Fonte Termal - solo & 31 & 08 & 485 & $20^{\circ} 43.133^{\prime}$ & $48^{0} 55.051^{\prime}$ & $\begin{array}{l}7.2 \text { marrom } \\
8.1 \text { branco }\end{array}$ \\
\hline 09 & $\begin{array}{l}\text { Termas } \\
\text { (Olímpia) }\end{array}$ & Entulho - solo & 31 & 08 & 485 & $20^{\circ} 43.133^{\prime}$ & $48^{0} 55.051^{-}$ & $\begin{array}{l}9.1 \text { verde } \\
\text { musgo }\end{array}$ \\
\hline \multirow[t]{2}{*}{10} & $\begin{array}{l}\text { Sta. Rita } \\
\text { do Oeste }\end{array}$ & $\begin{array}{l}\text { Terra próxima } \\
\text { ao solo }\end{array}$ & 27 & 09 & 394 & $20^{0} 27.114$ & $50^{0} 46.975^{\prime}$ & 10.1 cinza \\
\hline & & Interior da silagem & 27 & 09 & 394 & $20^{0} 27.114$ & $50^{0} 46.975^{\prime}$ & $\begin{array}{l}10.2 \text { verde } \\
10.3 \text { verde }\end{array}$ \\
\hline
\end{tabular}




\section{2- Seleção das linhagens produtoras de amilases em fermentação líquida}

Para a seleção das linhagens produtoras de amilases, todos os 19 fungos isolados, mais os fungos anteriormente isolados durante projeto Biota foram incubados em meio SR, suplementado com amido solúvel como fonte de carbono, em pH 6,0, por 72 horas a $35^{\circ} \mathrm{C}$, em condições de agitação e estáticas.

Os resultados (Tabela 2) mostraram que todas as linhagens isoladas cresceram e produziram as enzimas de interesse em quantidades consideráveis. O crescimento dos microrganismos isolados em meio que possui o amido solúvel como única fonte de carbono, por si só, mostra que esses produzem amilases extracelulares, uma vez que a molécula de amido, por apresentar alto peso molecular, não entra na célula. Dessa forma pode-se sugerir que até mesmo aquelas linhagens, para as quais foram detectadas baixas atividades enzimáticas, constituem-se de boas fontes dessas enzimas.

As linhagens denominadas 2.1, 3.1, C9A e as linhagens já identificadas A. ochaceus, A. niveus foram as que proporcionaram as maiores atividades específicas em condição estacionária $(206,7 ; 255,7 ; 396,2 ; 222,8$ e 427,7 U/mg prot.), respectivamente. Uma vez que o objetivo desse experimento foi selecionar a cepa melhor produtora de amilases para dar seqüência aos experimentos, ficou estabelecido que $A$. niveus seria ideal, tendo em vista que a mesma além de apresentar excelente potencial para produção das enzimas, também já se encontrava identificada. Ressalta-se que não consta na literatura dados referentes a produção de amilases por esse microrganismo. 
Tabela 2: Screening dos fungos isolados nas três coletas e também de fungos anteriormente isolados durante o projeto Biota.

\begin{tabular}{|c|c|c|c|c|c|c|c|c|}
\hline \multirow[t]{2}{*}{ Fungos } & \multicolumn{2}{|c|}{$\begin{array}{c}\text { Biomassa } \\
(\mathrm{mg})\end{array}$} & \multicolumn{2}{|c|}{$\begin{array}{c}\text { Proteínas }(\mathrm{mg}) \\
\text { Totais }\end{array}$} & \multicolumn{2}{|c|}{$\begin{array}{l}\text { Atividade } \\
\text { (U. totais) }\end{array}$} & \multicolumn{2}{|c|}{$\begin{array}{l}\text { Atividade Esp. } \\
\text { (U/mg prot.) }\end{array}$} \\
\hline & EST & AGT & EST & AGT & EST & AGT & EST & AGT \\
\hline 1.1 & 283,8 & 225,0 & 7,4 & 3,6 & 798,0 & 605,6 & 107,8 & 168,2 \\
\hline 1.2 & 302,5 & 260,0 & 6,0 & 4,4 & 902,6 & 788,0 & 150,3 & 179,0 \\
\hline 1.3 & 296,0 & 220,0 & 5,8 & 6,0 & 605,8 & 900,0 & 104,4 & 150,0 \\
\hline 1.4 & 116,1 & 267,0 & 8,6 & 9,8 & 592,0 & 975,8 & 68,8 & 99,6 \\
\hline 2.1 & 208,2 & 129,0 & 6,4 & 10,4 & 1323,4 & 290,2 & 206,7 & 27,9 \\
\hline 3.1 & 393,0 & 168,0 & 4,2 & 6,4 & 1074,0 & 843,4 & 255,7 & 131,7 \\
\hline 3.2 & 240,0 & 186,0 & 12,4 & 4,8 & 476,0 & 340,4 & 38,3 & 70,9 \\
\hline 4.1 & 420,0 & 288,0 & 5,0 & 3,2 & 590,0 & 266,8 & 118,0 & 83,3 \\
\hline 4.2 & 234,6 & 157,1 & 10,6 & 7,4 & 966,8 & 736,0 & 91,2 & 99,5 \\
\hline 5.1 & 420,0 & 300,0 & 11,8 & 5,0 & 572,4 & 569,0 & 48,5 & 113,8 \\
\hline 5.2 & 280,0 & 144,0 & 11,4 & 7,6 & 1020,3 & 626,0 & 89,4 & 82,3 \\
\hline 6.1 & 159,9 & 147,7 & 6,2 & 10,0 & 590,0 & 262,8 & 95,1 & 26,2 \\
\hline 7.1 & 189,0 & 132,0 & 6,2 & 10,2 & 932,4 & 818,8 & 150,3 & 80,1 \\
\hline 7.2 & 133,5 & 264,0 & 8,6 & 7,4 & 296,0 & 1433,2 & 34,4 & 193,6 \\
\hline 8.1 & 186,0 & 96,0 & 14,4 & 12,8 & 880,0 & 868,0 & 61,1 & 67,8 \\
\hline 9.1 & 321,0 & 99,0 & 6,2 & 8,0 & 697,0 & 440,0 & 112,4 & 55,0 \\
\hline 10.1 & 197,7 & 99,0 & 8,6 & 12,8 & 269,6 & 280,0 & 34,5 & 21,8 \\
\hline 10.2 & 277,5 & 342,0 & 11,6 & 3,4 & 1152,0 & 555,4 & 99,3 & 163,3 \\
\hline 10.3 & 327,0 & 315,0 & 5,0 & 5,2 & 450,0 & 740,0 & 90,0 & 142,3 \\
\hline P. herquei & 163,2 & 144,0 & 6,4 & 4,4 & 559,4 & 811,4 & 87,4 & 184,4 \\
\hline A.niveus & 336,0 & 447,0 & 4,0 & 4,8 & 1710,0 & 860,0 & 427,7 & 197,1 \\
\hline C7B & 256,2 & 324,0 & 6,2 & 5,8 & 700,0 & 225,0 & 113,0 & 38,8 \\
\hline C9A & 270,0 & 381,0 & 4,2 & 7,6 & 1664,0 & 660,0 & 396,2 & 86,8 \\
\hline $\begin{array}{c}\text { A. } \\
\text { ochraceus }\end{array}$ & 187,8 & 165,0 & 5,0 & 5,2 & 1114,0 & 942,8 & 222,8 & 181,3 \\
\hline
\end{tabular}




\section{3- Avaliação de diferentes meios de cultivo para a produção das enzimas}

Para os estudos dos diferentes meios de cultivo na produção de amilases, A. niveus foi inoculado em meios líquidos Adams, Czapeck, SR e Khanna, sob condições de agitação ou estático por 72 horas, a $40^{\circ} \mathrm{C}$ (Tabela 3). O meio Adams foi o que menos favoreceu o crescimento como a produção das enzimas. O meio SR sob condição estática favoreceu o crescimento do fungo, que por sua vez, secretou uma quantidade significativa de amilases para o meio (1089 U. totais). Já o meio Khanna em condição estática foi o que melhor favoreceu tanto o crescimento, quanto à síntese de amilases. Estes dados são interessantes para processos industriais, tendo em vista a economia de energia, o que aumenta a viabilidade do processo. Assim, foi possível concluir que o meio Khanna sob condição estática foi determinado como o melhor meio de cultivo dentre os testados e por isso, foi tomado para dar prosseguimento aos demais experimentos.

\section{4- Avaliação da concentração de inóculo sobre a produção das amilases}

A concentração ideal de inóculo para a produção das enzimas de acordo com o nosso modelo experimental foi determinada e os resultados são mostrados na Tabela 4. Utilizou-se meio de cultivo Khanna em condição estática, utilizando $\mathrm{pH}$ inicial 6,0 , por 72 horas a $40^{\circ} \mathrm{C}$. Os meios em volumes de $25 \mathrm{~mL}$ foram inoculados com suspensões de conídios, em concentrações de $0,5 \times 10^{5}, 1,0 \times 10^{5}, 2,5 \times 10^{5}, 5,0 \times 10^{5}, 7,5 \times 10^{5}, 1,0 \times 10^{6}, 1,5 \times 10^{6}$ e 2,0 x $10^{6}$ conídios $/ \mathrm{mL}$.

Foi possível observar que em todas as concentrações testadas o fungo apresentou um bom crescimento, bem como secretou as enzimas de interesse em grandes quantidades, porém, quando se utilizou uma concentração de $5,0 \times 10^{5}$ conídios $/ \mathrm{mL}$ foi detectada atividade enzimática correspondente a $24,3 \%$ maior que $0,5 \times 10^{5}$, onde o fungo obteve o menor 
crescimento. Assim, esta concentração foi tomada para dar seqüência aos demais experimentos.

Tabela 3: Diferentes meios de cultivo na produção de amilase por $A$. niveus.

\begin{tabular}{cccccc}
\hline \hline Meio & $\begin{array}{c}\text { Condição de } \\
\text { cultivo }\end{array}$ & $\begin{array}{c}\text { Biomassa } \\
(\mathbf{m g})\end{array}$ & $\begin{array}{c}\text { Proteínas } \\
(\mathbf{m g} \text { Totais })\end{array}$ & $\begin{array}{c}\text { Atividade } \\
\text { U. totais }\end{array}$ & $\begin{array}{c}\text { Atividade Esp. } \\
\text { U/mg prot. }\end{array}$ \\
\hline \hline Adams & agitação & 223,0 & 4,3 & 114,2 & 23,7 \\
Adams & estático & 307,2 & 5,8 & 171,4 & 26,7 \\
Czapeck & agitação & 265,5 & 11,6 & 544,7 & 41,2 \\
Czapeck & estático & 336,0 & 11,0 & 262,8 & 21,5 \\
SR & agitação & 428,4 & 18,4 & 285,7 & 14,2 \\
SR & estático & 435,0 & 20,1 & 1089,5 & 48,6 \\
Khanna & agitação & 540,0 & 27,6 & 613,3 & 20,0 \\
Khanna & estático & 596,4 & 30,7 & 2754,2 & 81,4 \\
\hline \hline
\end{tabular}

A. niveus foi cultivado em $\mathrm{pH}$ inicial de meio 6,0 , por 72 horas a $40^{\circ} \mathrm{C}$.

Tabela 4: Efeito da concentração de inóculo sobre a produção das amilases por $A$. niveus.

\begin{tabular}{ccccc}
\hline \hline $\begin{array}{c}\text { Inóculo } \\
\text { Conídios/mL }\end{array}$ & $\begin{array}{c}\text { Biomassa } \\
(\mathbf{m g})\end{array}$ & $\begin{array}{c}\text { Proteínas } \\
(\mathbf{m g} \text { Totais })\end{array}$ & $\begin{array}{c}\text { Atividade } \\
\text { Unidades totais }\end{array}$ & $\begin{array}{c}\text { Atividade Esp. } \\
\text { U/mg prot. }\end{array}$ \\
\hline \hline $0,5 \times 10^{5}$ & 178,5 & 5,84 & 1546,6 & 246,8 \\
$1,0 \times 10^{5}$ & 224,6 & 7,2 & 1699,0 & 234,9 \\
$2,5 \times 10^{5}$ & 248,0 & 8,6 & 1876,2 & 217,9 \\
$5,0 \times 10^{5}$ & 276,3 & 8,0 & 2042,0 & 255,2 \\
$7,5 \times 10^{5}$ & 298,5 & 9,0 & 1756,0 & 195,0 \\
$1,0 \times 10^{6}$ & 302,4 & 8,7 & 1615,2 & 202,0 \\
$1,5 \times 10^{6}$ & 305,0 & 8,0 & 1676,2 & 209,5 \\
$2,0 \times 10^{6}$ & 310,0 & 13,2 & 1453,3 & 111,8 \\
\hline \hline
\end{tabular}

A. niveus foi cultivado em meio Khanna com $\mathrm{pH}$ inicial 6,0 , por 72 horas a $40^{\circ} \mathrm{C}$. 


\section{5- Combinação de métodos físicos visando aumento da produção enzimática}

No estudo de diferentes condições de cultivo para a produção de amilases, o fungo foi incubado em meio Khanna por 72 horas, em $\mathrm{pH}$ inicial de meio de cultivo 6,0 a $40^{\circ} \mathrm{C}$, combinando as condições de cultivo entre agitação e estático (72 horas sob agitação, 72 horas em estático, 24 horas em agitação, seguida de 48 horas estático, 48 horas em agitação seguida de 24 horas em estático, 24 horas em estático seguida de 48 horas em agitação e 48 horas em estático seguida de 24 horas em agitação).

O objetivo desse experimento foi verificar se a mudança de condição física de cultivo durante o crescimento acarretaria em um aumento no crescimento e na secreção das enzimas. Os resultados (Tabela 5) mostram que das condições de cultivo analisadas, 72 horas, sob condição estática, foi a que mais favoreceu o crescimento e a síntese das enzimas. Assim, essa condição foi tomada para dar seqüência aos experimentos.

\section{6- Efeito do tempo de cultivo sobre a produção das amilases}

Para o estudo do efeito do tempo de cultivo sobre a produção das enzimas, o fungo foi cultivado durante 144 horas (Figura 5). Alíquotas foram retiradas a cada 24 horas para as dosagens de atividade enzimática e proteínas totais do meio. Foi possível observar um crescimento rápido e também altos níveis das enzimas amilolíticas extracelulares. O pico de crescimento do microrganismo foi observado em 48 horas de cultivo e a de atividade enzimática máxima ocorreu em 72 horas, tempo esse relativamente curto o que acarretaria um menor custo para produção em grande escala. A atividade específica também foi maior em 72 horas de crescimento, sendo esta 5,3 vezes maior que aquela determinada nos dois últimos dias de cultivo. 
Desta forma, pode-se concluir que o tempo de cultivo mais adequado para a produção de amilases por A.niveus foi de 72 horas, sendo este escolhido para dar prosseguimento aos demais experimentos.

Tabela 5: Diferentes condições de cultivo A. niveus.

\begin{tabular}{ccccc}
\hline \hline $\begin{array}{c}\text { Condição } \\
\text { de cultivo }\end{array}$ & $\begin{array}{c}\text { Biomassa } \\
(\mathbf{m g})\end{array}$ & $\begin{array}{c}\text { Proteínas } \\
\text { (mg Totais) }\end{array}$ & $\begin{array}{c}\text { Atividade } \\
\text { (U. totais) }\end{array}$ & $\begin{array}{c}\text { Atividade Esp. } \\
\text { (U/mg prot.) }\end{array}$ \\
\hline \hline $24 \mathrm{~A}+48 \mathrm{E}$ & 220,6 & 15.96 & 868,0 & 54,38 \\
$48 \mathrm{~A}+24 \mathrm{E}$ & 249,4 & 10,6 & 470,4 & 44,37 \\
$72 \mathrm{~A}$ & 262,6 & 9,6 & 723,7 & 75,38 \\
$24 \mathrm{E}+48 \mathrm{~A}$ & 164,30 & 24,0 & 365,6 & 20,0 \\
$48 \mathrm{E}+24 \mathrm{~A}$ & 231,7 & 16,8 & 2030,4 & 120,8 \\
$72 \mathrm{E}$ & 291,85 & 19,6 & 2521,8 & 128,6 \\
\hline \hline
\end{tabular}

A. niveus foi cultivado em meio Khanna com $\mathrm{pH}$ inicial 6,0 , por 72 horas a $40^{\circ} \mathrm{C}$.

$\mathrm{A}=$ agitação

$\mathrm{E}=$ estático

24 e $48=$ tempos de cultivo (horas)

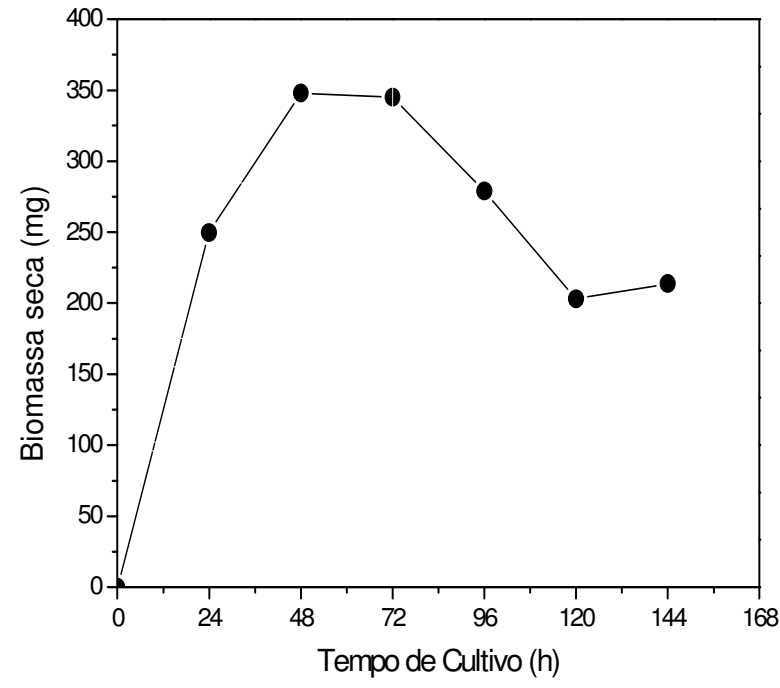

(A)

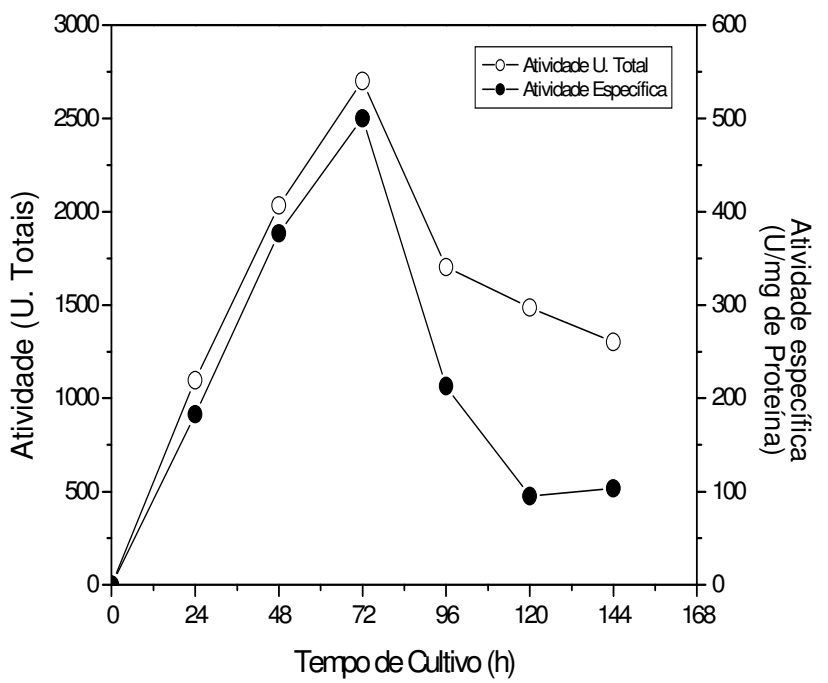

(B)

Figura 5: Efeito do tempo de cultivo sobre a produção de amilases por A. niveus. (A)- Biomassa seca e (B)- Atividade específica e atividade unidades totais. 


\section{7- Efeito do pH inicial de meio de cultivo sobre a produção das enzimas amilolíticas}

Para o estudo do efeito do $\mathrm{pH}$ inicial de meio de cultivo sobre a produção das amilases, A. niveus foi cultivado por 72 horas a $40^{\circ} \mathrm{C}$ e os meios de cultivo tiveram seus pHs iniciais corrigidos entre valores de 4,5 e 7,0 com intervalos de 0,5. A Tabela 6 ilustra o crescimento e a produção enzimática nos diferentes valores de pHs iniciais.

Analisando-se os dados, pôde-se verificar que o maior crescimento do fungo ocorreu em meios de cultivos com pHs iniciais entre 5,0 e 6,5 o que mostra que os pHs próximos a neutralidade favoreceram o crescimento do mesmo. Quanto à produção enzimática foi possível observar um perfil semelhante aquele mostrado para o crescimento, o que possivelmente estaria associado às necessidades nutricionais e também fisiológicas do microrganismo. A maior atividade enzimática foi determinada em meio de cultivo com $\mathrm{pH}$ inicial 6,5 , valor este adotado para dar prosseguimento aos demais experimentos.

\section{8- Efeito da temperatura de cultivo sobre a produção das amilases}

Para o estudo do efeito da temperatura sobre a produção das amilases, conidios de $A$. niveus foram inoculados em meio Khanna e mantidos em temperaturas que variaram de 25 a $50^{\circ} \mathrm{C}$, em intervalos de $5^{\circ} \mathrm{C}$, em meio com $\mathrm{pH}$ inicial 6,5.

Os resultados (Tabela 7) mostram que A. niveus foi hábil em crescer em temperaturas entre 25 e $45^{\circ} \mathrm{C}$, porém na temperatura de $50^{\circ} \mathrm{C}$ o crescimento foi drasticamente reduzido. Foi possível observar ainda que não houve diferença significativa no crescimento do fungo nas temperaturas de 35,40 e $45^{\circ} \mathrm{C}$, porém nota-se que a $40^{\circ} \mathrm{C}$ a massa micelial formada foi ligeiramente maior que as das demais temperaturas. Assim, pode-se inferir que a linhagem em questão pode ser considerada termotolerante, uma vez que cresceu bem a $45^{\circ} \mathrm{C}$. 
O pico de atividade enzimática foi detectado em meio de cultivo a $40^{\circ} \mathrm{C}$ e as temperaturas superiores a essa proporcionaram uma queda acentuada na produção das enzimas. Assim, pôde se concluir que $40^{\circ} \mathrm{C}$ foi a temperatura adequada para a produção de amilases e, portanto, tomada para dar seqüência aos experimentos posteriores.

Tabela 6: Efeito do pH inicial de meio de cultivo para produção de amilases por $A$. niveus.

\begin{tabular}{cccccc}
\hline \hline $\mathbf{p H}$ & $\mathbf{p H}$ final & Biomassa & Proteínas & Atividade & Atividade Esp. \\
inicial & & $(\mathbf{m g})$ & $(\mathbf{m g}$ Totais $)$ & (U. totais) & (U/mg prot.) \\
\hline \hline 4,5 & 7,65 & 266,3 & 15,2 & 1205,6 & 79,31 \\
5,0 & 7,40 & 327,3 & 15,6 & 1660,8 & 106,46 \\
5,5 & 7,30 & 235,2 & 15,2 & 1780,0 & 117,65 \\
6,0 & 7,40 & 206,4 & 15,8 & 2000,0 & 126,58 \\
6,5 & 7,20 & 326,4 & 17,8 & 2380,0 & 133,47 \\
7,0 & 7,65 & 198,2 & 15,4 & 1832,2 & 118,97 \\
\hline \hline
\end{tabular}

A. niveus foi cultivado em meio Khanna por 72 horas a $40^{\circ} \mathrm{C}$. 
Tabela 7: Efeito da temperatura de cultivo na produção de amilases por $A$. niveus.

\begin{tabular}{ccccc}
\hline \hline $\begin{array}{c}\text { Temperatura } \\
\left({ }^{\circ} \mathbf{C}\right)\end{array}$ & $\begin{array}{c}\text { Biomassa } \\
(\mathbf{m g})\end{array}$ & $\begin{array}{c}\text { Proteínas } \\
(\mathbf{m g} \text { Totais })\end{array}$ & $\begin{array}{c}\text { Atividade } \\
(\text { U. totais })\end{array}$ & $\begin{array}{c}\text { Atividade Esp. } \\
\text { (U/mg prot. })\end{array}$ \\
\hline \hline 25 & 306,0 & 6,4 & 567,6 & 88,6 \\
30 & 336,0 & 8,1 & 1751,4 & 215,1 \\
35 & 360,0 & 7,2 & 1701,3 & 234,3 \\
40 & 364,8 & 5,8 & 2323,8 & 395,0 \\
45 & 345,7 & 4,5 & 708,5 & 157,3 \\
50 & 62,4 & 8,3 & 34,2 & 4,1 \\
\hline \hline
\end{tabular}

A. niveus foi cultivado em meio Khanna com $\mathrm{pH}$ inicial 6,5, por 72 horas.

\section{9- Avaliação de diferentes fontes de carbono sobre a produção das amilases}

Essa etapa do trabalho consistiu na avaliação da produção enzimática por A. niveus quando cultivado em diferentes fontes de carbono a $1 \%$. A temperatura de incubação foi de $40^{\circ} \mathrm{C}$ e o pH inicial do meio foi 6,5 , conforme definidos nos experimentos anteriores. Amido solúvel comercial e meio de cultivo sem fonte de carbono foram tomados como controles e os resultados são mostrados na Tabela 8.

Entre as fontes de carbono testadas milho moído, farinha de aveia, palha de arroz e maizena foram as que melhores induziram a atividade amilásica, sendo estes superiores em 1,$9 ; 1,6 ; 1,0$ e 1,1 vezes ao amido solúvel, respectivamente, e 18,$4 ; 16,0 ; 10,5$ e 10,2 vezes mais que o meio de cultivo sem fonte de carbono. Seria de se esperar que milho moído, farinha de aveia e maizena fossem boas fontes indutoras, uma vez que são complexas, com altos teores de íons e vitaminas, que por sua vez são importantes para o crescimento do 
microrganismo. Já a palha de arroz é constituída basicamente de celulose e hemicelulose que não são substratos específicos para amilases.

Maltose, farelo de trigo, glicose, penetrose, amilopectina e rafinose também demonstraram excelente capacidade de indução das amilases. Já bagaço de cana, sacarose, lactose e arabinose foram as piores fontes indutoras da síntese das enzimas, 2,4; 4,6; 7,2 e 9,3 vezes menor que amido solúvel, respectivamente.

\subsection{0- Efeito da concentração da fonte de carbono na produção das amilases}

Esta etapa do trabalho consistiu em avaliar qual a concentração de fonte de carbono mais adequada para a síntese das amilases (Tabela 9). Foram utilizados como fontes de carbono milho moído, uma vez que foi a fonte que mais induziu a síntese enzimática e amido solúvel comercial, o qual tem sido utilizado desde o início dos experimentos. Os cultivos foram feitos nas condições ideais de $\mathrm{pH}$ inicial de meio, tempo e temperatura, definidos anteriormente.

Os resultados mostraram uma maior produção enzimática em baixas concentrações de amido solúvel como fonte de carbono. Pode-se considerar que concentrações entre 0,25 e 0,75\% são as mais adequadas para a indução da síntese das amilases. Em concentrações superiores a $1 \%$ foi possível observar um declínio acentuado na atividade enzimática, mesmo não havendo praticamente nenhuma diferença significativa do crescimento do microrganismo em todas as concentrações testadas. Ainda com relação aos resultados, foi possível observar que não houve diferença significativa entre os valores de atividade enzimática obtidos com concentrações de fonte de carbono 0,25, 0,50 e 0,75\%, ficando, assim, estabelecido que 0,25\% seria a concentração ideal. Para os resultados observados com diferentes concentrações de 
milho moído como fonte indutora, nota-se não ter havido diferença significativa no crescimento do fungo, porém um pico de atividade significativamente maior foi detectado em meio de cultivo com $1 \%$ de fonte de carbono. Assim, foi possível concluir que $1 \%$ de fonte de carbono, quando se usa milho moído, induz com mais eficiência a síntese das amilases por $A$. niveus.

Tabela 8: Efeito da fonte de carbono na produção de amilases por A. niveus.

\begin{tabular}{lccc}
\hline Fonte de carbono & $\begin{array}{c}\text { Proteínas }(\mathbf{m g}) \\
\text { Totais }\end{array}$ & $\begin{array}{c}\text { Atividade } \\
\text { (U. totais) }\end{array}$ & $\begin{array}{c}\text { Atividade Esp. } \\
\text { (U/mg prot.) }\end{array}$ \\
\hline \hline Milho moído & 18,0 & 4000,0 & 222,2 \\
Farinha aveia & 19,0 & 3474,2 & 182,1 \\
Palha de Arroz & 25,2 & 2280,0 & 114,2 \\
Maizena & 14,6 & 2228,4 & 152,6 \\
Amido solúvel & 12,8 & 2137,0 & 167,0 \\
Maltose & 13,0 & 1748,6 & 133,8 \\
Farelo Trigo & 24,8 & 1737,0 & 70,0 \\
Glicose & 10,8 & 1737,0 & 160,8 \\
Penetrose & 12,4 & 1702,8 & 137,3 \\
Amilopectina & 9,2 & 1360,0 & 147,8 \\
Rafinose & 12,4 & 1188,4 & 95,8 \\
Bagaço de Cana & 17,6 & 902,8 & 51,1 \\
Sacarose & 18,4 & 457,0 & 23,9 \\
Sabugo Milho & 23,0 & 308,5 & 13,4 \\
Lactose & 11,4 & 297,0 & 26,0 \\
Arabinose & 18,8 & 228,4 & 12,1 \\
Sem fonte & 5,0 & 217,0 & 40,0 \\
\hline \hline
\end{tabular}

A. niveus foi cultivado em meio Khanna-estático com $\mathrm{pH}$ inicial 6,5 , por 72 horas a $40^{\circ} \mathrm{C}$. 
Tabela 9: Efeito da concentração da fonte de carbono (amido solúvel e milho moído) na produção das amilases por $A$. niveus.

\begin{tabular}{|c|c|c|c|c|c|c|c|c|}
\hline \multirow[t]{2}{*}{$\begin{array}{c}\text { Fonte } \\
\text { de } \\
\text { carbono } \\
(\%)\end{array}$} & \multicolumn{2}{|c|}{$\begin{array}{c}\text { Biomassa } \\
\text { (mg) }\end{array}$} & \multicolumn{2}{|c|}{$\begin{array}{c}\text { Proteínas (mg) } \\
\text { Totais }\end{array}$} & \multicolumn{2}{|c|}{$\begin{array}{l}\text { Atividade } \\
\text { (U. totais) }\end{array}$} & \multicolumn{2}{|c|}{$\begin{array}{l}\text { Atividade Esp. } \\
\text { (U/mg prot.) }\end{array}$} \\
\hline & $A S$ & $M M$ & $A S$ & $M M$ & $A S$ & $M M$ & $\mathbf{A S}$ & MM \\
\hline 0,25 & 326,0 & 288,0 & 5,0 & 5,2 & 1325,7 & 845,7 & 265,1 & 162,6 \\
\hline 0,50 & 365,5 & 302,6 & 4,0 & 6,9 & 1188,5 & 857,2 & 294,2 & 123,5 \\
\hline 0,75 & 388,9 & 356,7 & 4,2 & 8,9 & 1040,0 & 982,8 & 247,6 & 110,4 \\
\hline 1,0 & 404,5 & 359,0 & 3,0 & 9,7 & 582,8 & 2516,0 & 194,0 & 258,6 \\
\hline 1,25 & 403,9 & 406,3 & 3,6 & 11,7 & 274,3 & 1188,6 & 76,1 & 121,3 \\
\hline 1,50 & 405,8 & 419,4 & 3,8 & 10,4 & 205,7 & 868,6 & 54,1 & 73,7 \\
\hline 1,75 & 355,0 & 395,3 & 3,8 & 9,8 & 215,2 & 1051,4 & 56,6 & 100,4 \\
\hline 2,0 & 360,6 & 320,8 & 3,2 & 12,3 & 285,7 & 1416,0 & 87,1 & 115,1 \\
\hline
\end{tabular}

A. niveus foi cultivado em meio Khanna-estático com $\mathrm{pH}$ inicial 6,5 , por 72 horas a $40^{\circ} \mathrm{C}$. $\mathrm{AS}=$ amido solúvel $\mathrm{MM}=$ milho moído

\subsection{1- Efeito da adição de glicose no meio de cultivo sobre a produção de amilases}

Para o estudo do efeito da adição de glicose no meio de cultivo sobre a síntese das amilases, A. niveus foi cultivado em meio contendo amido solúvel $0,25 \%$ como fonte de carbono, suplementado com glicose em concentrações de 0,$1 ; 0,25 ; 0,50 ; 1,0$ e $2 \%$. Amido solúvel a $0,25 \%$ ou glicose $2 \%$ foram tomados como controle (Tabela 10 ).

O crescimento do microrganismo foi favorecido por adições crescentes de glicose no meio, porém a síntese enzimática diminuiu a medida em que aumentou a concentração de 
glicose no meio, o que indica estar ocorrendo uma repressão na síntese das enzimas por esse sacarídeo. A atividade enzimática verificada em meios contendo apenas glicose ocorre em função da presença de amilases constitutivas.

Tabela 10: Efeito da adição de glicose na produção de amilases por $A$. niveus.

\begin{tabular}{cccccc}
\hline Fonte de & Biomassa & Proteínas & Atividade & Atividade Esp. & Atividade \\
carbono (\%) & $(\mathbf{m g})$ & $(\mathbf{m g}$ Totais $)$ & (U. totais) & (U/mg prot.) & Relativa \\
& & & & & $(\%)$ \\
\hline \hline A 0,25 & 207,1 & 5,6 & 1348,0 & 240,8 & 100 \\
A + G 0,1 & 217,6 & 5,2 & 902,8 & 173,6 & 72,0 \\
A + G 0,25 & 219,6 & 5,2 & 891,0 & 171,4 & 71,0 \\
A + G 0,50 & 221,5 & 3,6 & 617,0 & 171,3 & 71,0 \\
A + G 1,0 & 235,6 & 3,6 & 331,0 & 92,0 & 38,2 \\
A + G 2,0 & 252,0 & 4,4 & 103,0 & 23,3 & 9,6 \\
G 2 & 207,4 & 5,4 & 697,0 & 129,0 & 53,6 \\
\hline \hline
\end{tabular}

A. niveus foi cultivado em meio Khanna-estacionário com $\mathrm{pH}$ inicial 6,5 , por 72 horas a $40^{\circ} \mathrm{C} . \mathrm{A}=$ amido solúvel $(0,25 \%) \quad \mathrm{G}=$ glicose

\subsection{2- Identificação dos produtos de hidrólise do amido solúvel}

Com o intuito de avaliar o perfil de distribuição dos açúcares redutores liberados durante a hidrólise do amido, a solução de amido comercial a $1 \%$ foi incubada junto aos extratos enzimáticos de A. niveus obtidos a partir de meio de cultivo contendo amido solúvel, 
glicose, palha de arroz, maizena e maltose como fonte de carbono, em condições ideais de $\mathrm{pH}$ e temperatura de meio de cultivo.

Analisando-se os cromatogramas (Figura 6 A e B) observa-se a presença nítida de três bandas correspondentes aos padrões de glicose, maltose e maltotriose quando os extratos enzimáticos foram obtidos em meios com amido solúvel e maltose como fonte de carbono. Para as bandas correspondentes a glicose, possivelmente, trata-se de resultado da ação de glucoamilases, e as bandas correspondentes a maltose e maltotriose são relativas à ação de $\alpha$ amilase. Bandas correspondentes a glicose e maltose foram detectadas como resultado da hidrólise do amido com extratos provenientes de meios de cultivos com glicose, maizena e palha de arroz como fontes indutoras. 


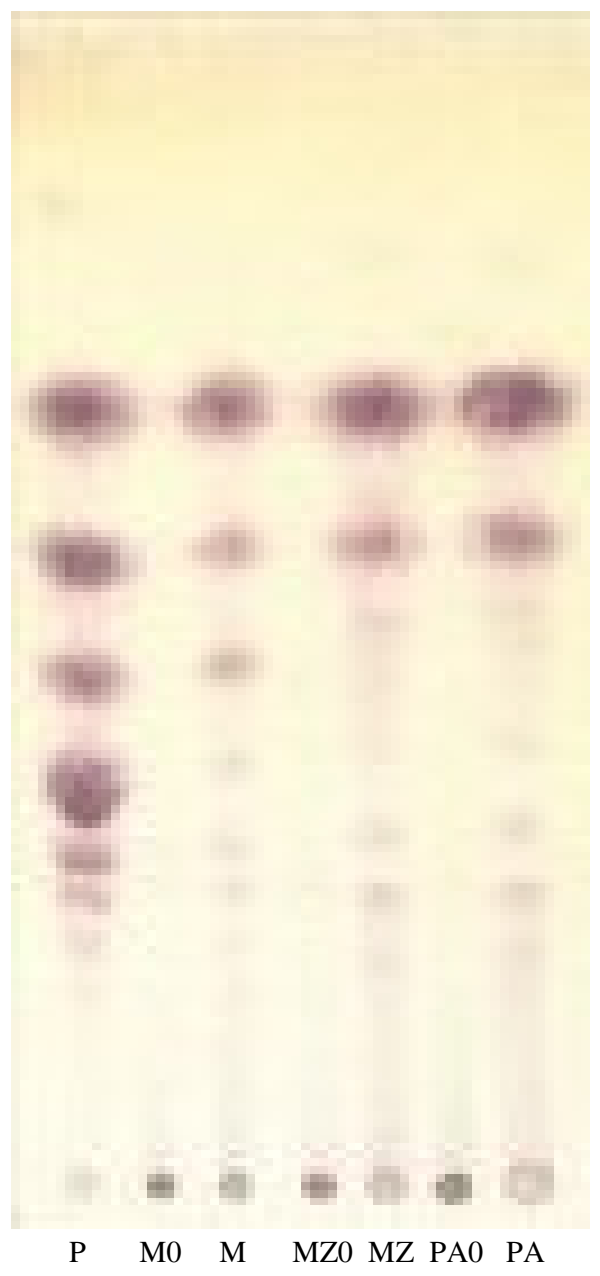

A

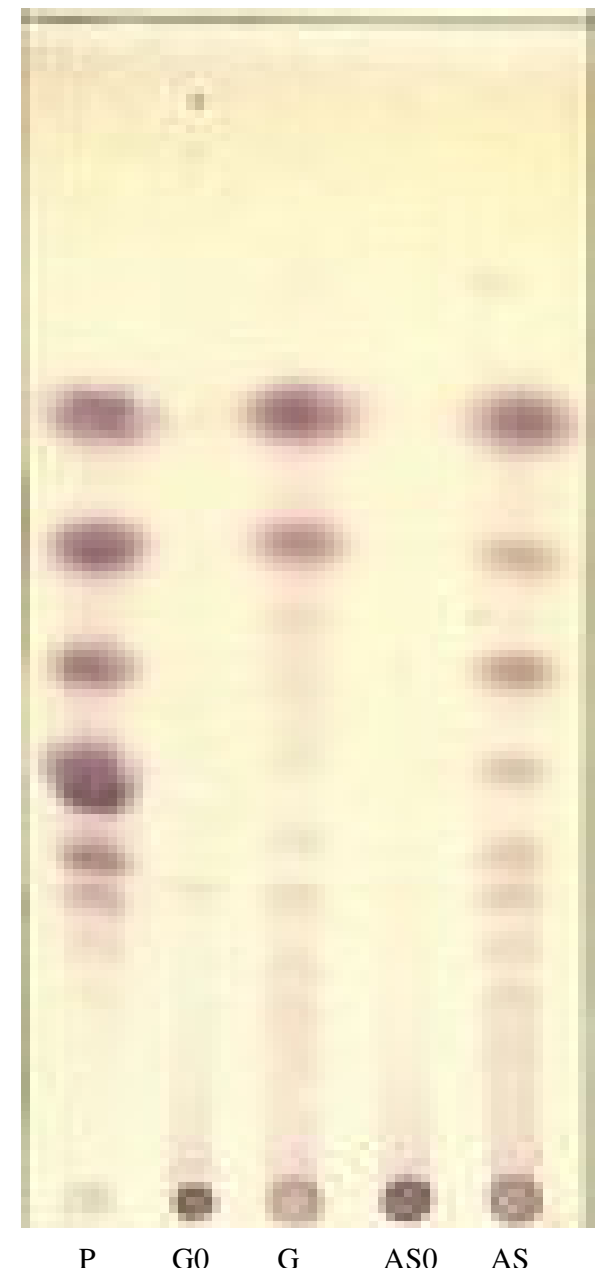

B

Figura 6: Cromatografia em camada delgada dos produtos de hidrólise do amido solúvel a $1 \%$, a $60^{\circ} \mathrm{C}$, por duas horas, pelas amilases de A. niveus, produzidas em meios com maltose, maizena, palha de arroz, glicose e amido solúvel como fontes de carbono.

P-padrões; M0- enzimas produzidas em meio com maltose + substrato amido, antes da reação; M produto de hidrólise do amido pelas enzimas produzidas em meio com maltose; MZ0- enzimas produzidas em meio com maizena + substrato amido, antes da reação; MZ- produto de hidrólise do amido pelas enzimas produzidas em meio com maizena; PA0- enzimas produzidas em meio com palha de arroz + substrato amido, antes da reação ; PA- produto de hidrólise do amido pelas enzimas produzidas em meio com palha de arroz; G0- enzimas produzidas em meio com glicose + substrato amido, antes da reação; Gproduto de hidrólise do amido pelas enzimas produzidas em meio com glicose; AS0- enzimas produzidas em meio com amido solúvel + substrato amido, antes da reação e AS- produto de hidrólise do amido pelas enzimas produzidas em meio com amido solúvel. 


\subsection{3- Hidrólise de diferentes substratos pelas amilases do extrato enzimático bruto}

Esta etapa do trabalho consistiu em avaliar a ação das enzimas amilolíticas contidas no extrato enzimático bruto quando incubadas com amido, substratos amiláceos, derivados de amido, glicogênio, sacarose, trealose e celobiose. O amido Reagen foi tomado como controle, uma vez que tem sido usado como substrato desde o inicio dos ensaios. A atividade enzimática foi determinada pelo método descrito no item 8.1 e 8.2 de Material e Métodos e os resultados são mostrados na Figura 7.

As enzimas presentes no extrato enzimático bruto apresentaram boa atividade na presença de amido Sigma, amilose, penetrose, maltose e amilopectina. Foi possível verificar atividade na presença de glicogênio, o que correspondem a 56\% em relação ao controle. Os substratos trealose, sacarose, $\beta$-ciclodextrina e celobiose não foram hidrolisados.

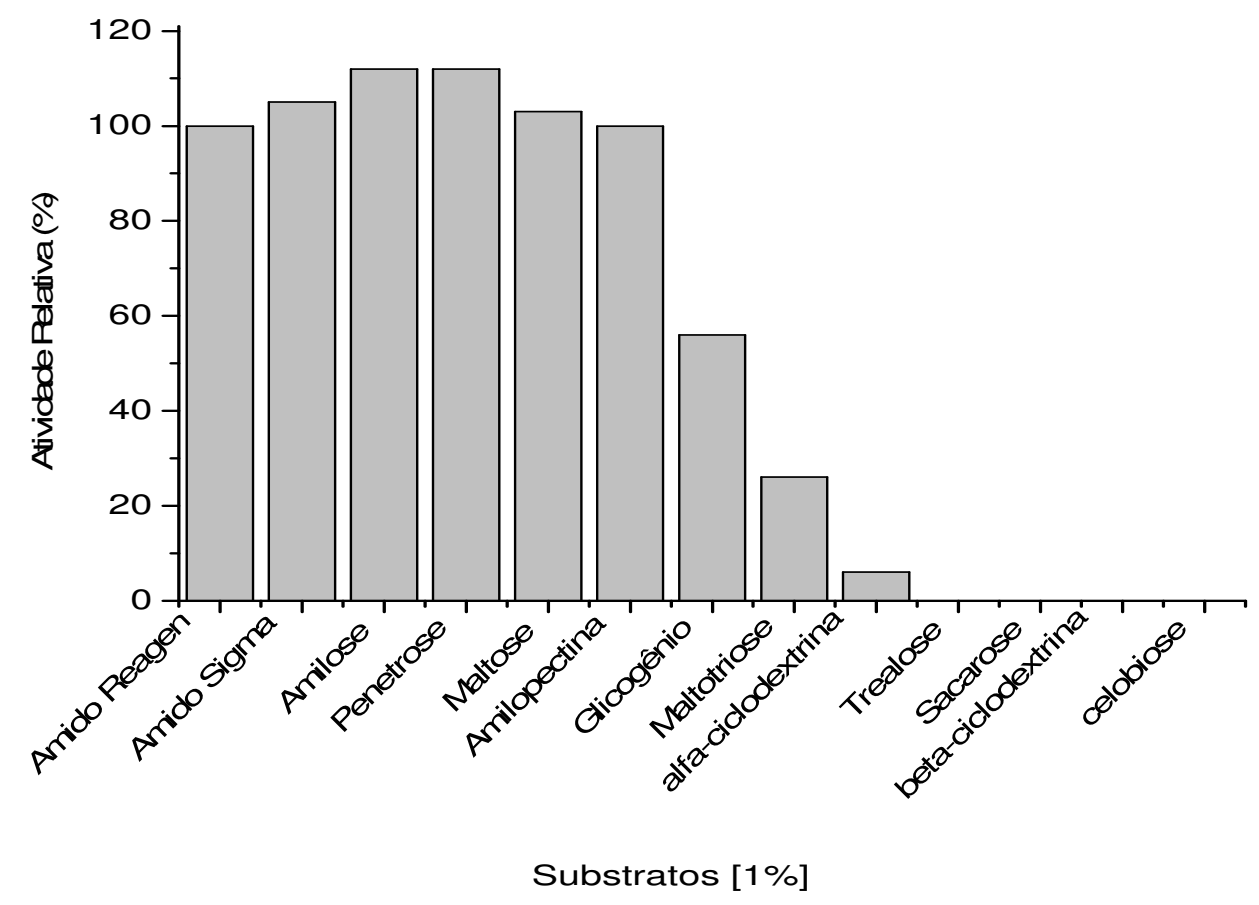

Figura 7: Atividade amilolítica frente a diferentes substratos usando extrato enzimático bruto. 


\subsection{4- Avaliação da capacidade de hidrólise do amido solúvel e amiláceos}

A avaliação da capacidade hidrolítica das amilases contidas no extrato enzimático bruto foi feita usando substratos com altas concentrações de amido como farelo de trigo, flocos de milho, flocos de aveia, flocos de cevada, flocos de centeio, farinha de mandioca e também flocos de soja. Foram acrescentados em meio reacional o equivalente a 3,6 U enzimática por mg de substrato. Os substratos foram preparados em tampão acetato de sódio 0,1M em pH 5,0 em uma concentração de 1\%. As dosagens enzimáticas foram feitas segundo descrito no item 8.1 e os resultados são mostrados na Figura 8.

Amido solúvel e farinha de mandioca foram os substratos mais susceptíveis ao ataque das enzimas, sendo liberados 46 e $47 \mu \mathrm{mol}$ de açúcares redutores durante o ensaio. As enzimas apresentaram boas atividades sobre flocos de milho, flocos de cevada, flocos de aveia e flocos de centeio, sendo liberados no ensaio 32, 31, 28 e 27 4mol de açúcares redutores, respectivamente. Quanto aos substratos farelo de trigo e flocos de soja, observou-se atividades inferiores em comparação aos demais substratos, sendo liberados 16 e 2,0 $\mu$ mols de açúcares redutores. Este resultado já era esperado, uma vez que os substratos em questão não apresentam em sua constituição os mesmos níveis de amido contidos naqueles que proporcionaram melhor rendimento. 


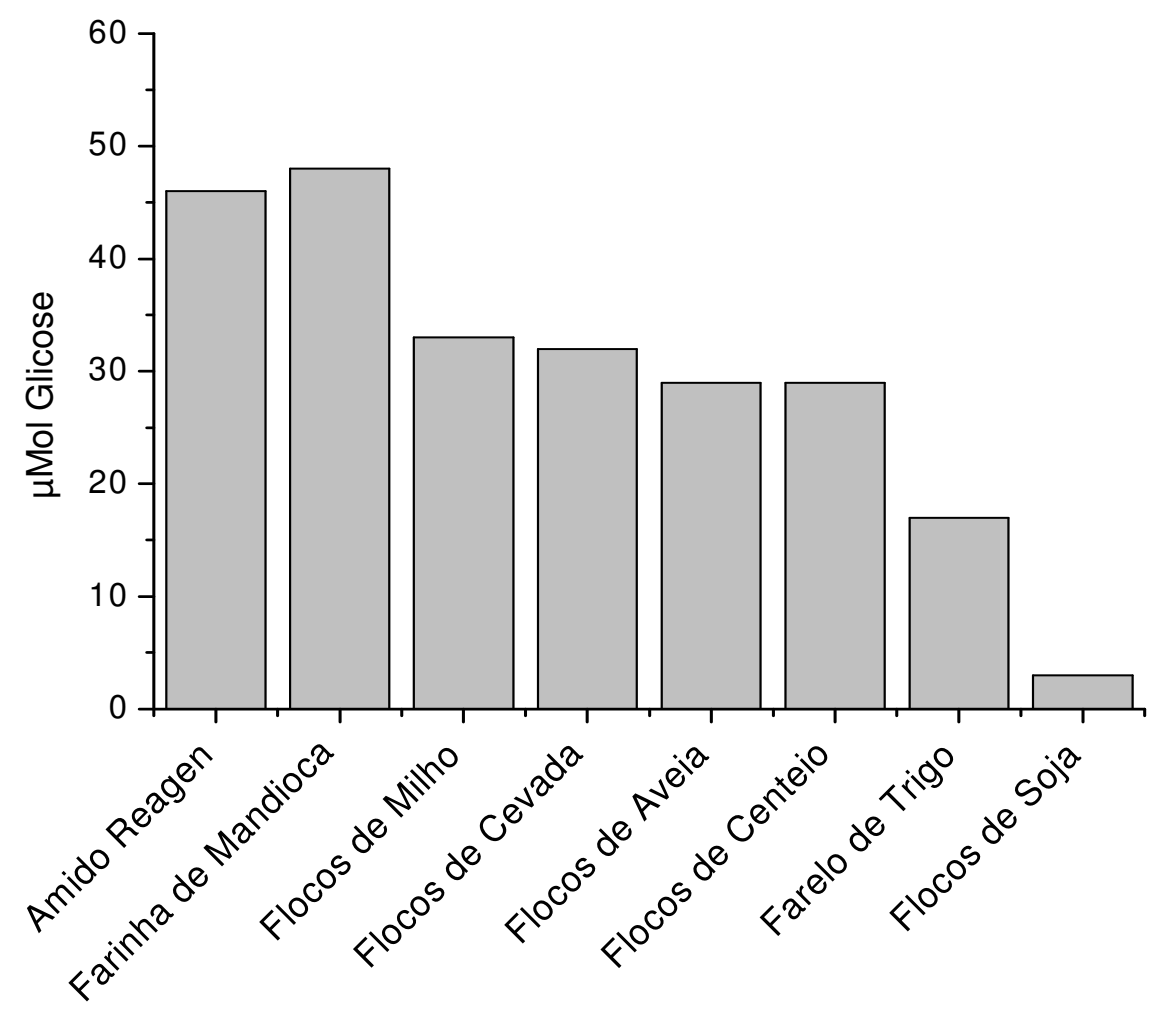

Figura 8: Avaliação da capacidade hidrolítica sobre o amido e amiláceos utilizando extrato enzimático bruto.

\subsection{5- Estudo da casca de mandioca como fonte de carbono}

\subsection{1- Determinação dos parâmetros físicos}

A influencia do tempo de cultivo e da aeração no crescimento do fungo e na secreção das amilases foi monitorada durante 6 dias de cultivo, em meios contendo casca de mandioca $1 \%$ como fonte de carbono alternativa. Consideráveis diferenças foram observadas comparando as culturas desenvolvidas sob condições estáticas e em agitação. A atividade amilolítica foi 3 vezes maior em condições estáticas de cultivos, em 48 horas, em relação a condição de agitação (Figura 9 A). 
4.15.2- Efeito do pH inicial, temperatura e adição de amido solúvel no meio de cultivo sobre a produção das amilases

O fungo foi capaz de produzir amilases em todos os $\mathrm{pHs}$ testados, entretanto, o $\mathrm{pH}$ ótimo ocorreu em 6,5 conforme mostra a Figura 9 B. Com relação a temperatura ótima para produção das enzimas observou-se que a $35^{\circ} \mathrm{C}$ os níveis de atividade foram os mais elevados, porém quantidades próximas foram produzidas a $40^{\circ} \mathrm{C}$ (Figura $9 \mathrm{C}$ ). Esse resultado nos permite inferir que esse fungo pode ser considerado termotolerante, uma vez que cresce sob baixa tensão de oxigênio e em temperaturas mais elevadas.

Similares níveis de amilases foram determinados na presença de amido solúvel e casca de mandioca. Um aumento de 50\% na atividade foi determinado quando houve a mistura de amido solúvel com casca de mandioca na mesma proporção (Figura 9 D). Esses resultados são de significativa importância levando em consideração que a casca de mandioca é um resíduo da agricultura que normalmente é descartado após o processamento da mandioca. O uso deste resíduo além de diminuir o impacto ao meio ambiente também diminui os custos de produção das enzimas, pois substitui amido e derivados que normalmente são utilizados como fontes indutoras da síntese das amilases. 

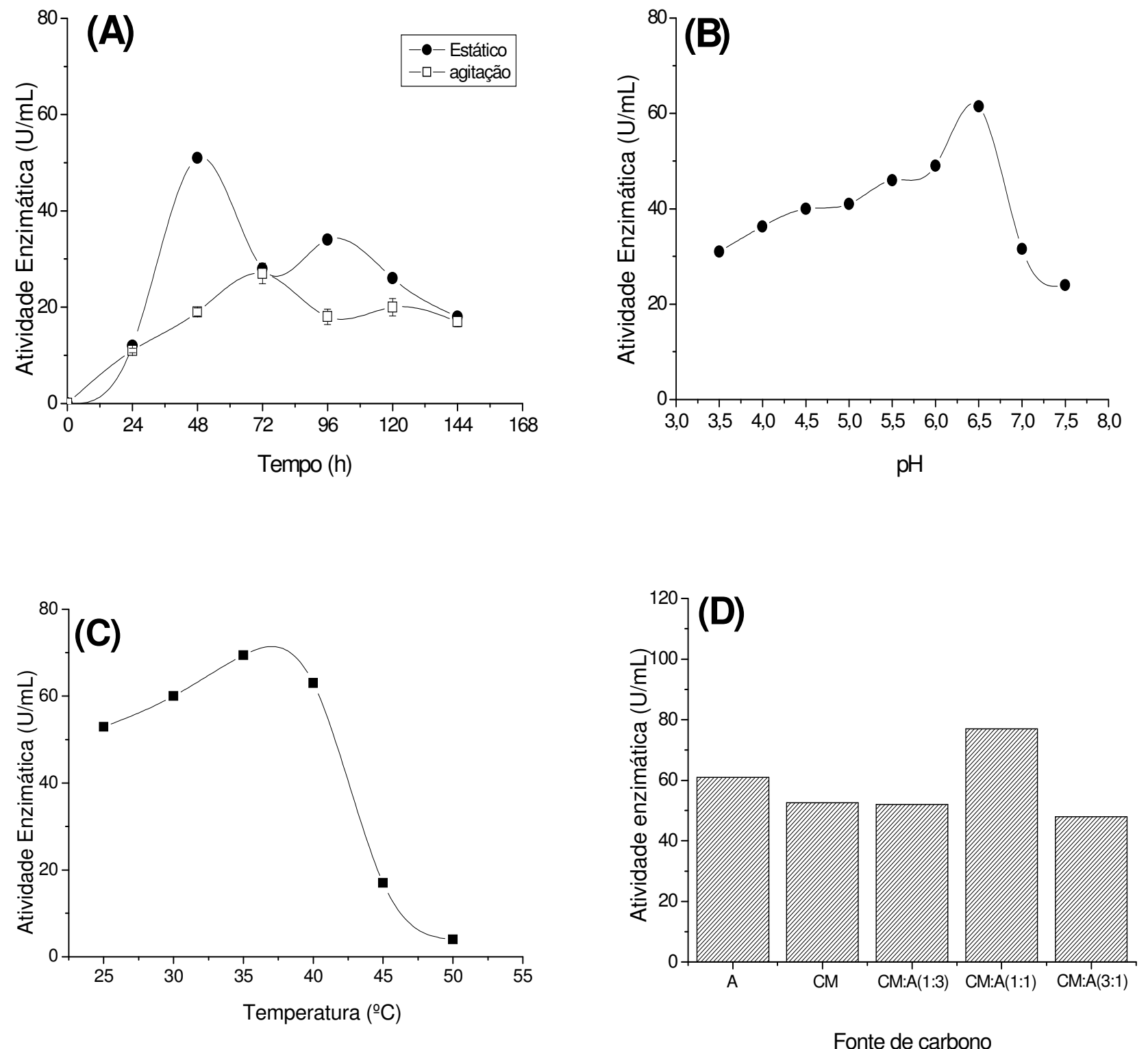

Figura 9: Tempo de cultivo e produção de amilases em condição física de cultivo estático e agitação. (A) pH inicial de cultivo (B). Influencia da temperatura na produção das amilases (C) e efeito da adição de amido solúvel na produção das amilases (D). A - amido, CM - casca de mandioca. 


\subsection{3- Análise da hidrólise de diferentes substratos por TLC e atividade} amilolítica em gel de poliacrilamida (PAGE)

As amilases de A. niveus hidrolisaram eficientemente (70-100\%) maltose, amido solúvel, penetrose, amilose, isomaltose e maltotriose. Considerável atividade foi observada em glicogênio e amilopectina (50 e 46\%), respectivamente. Ciclodextrina ( $\alpha$ e $\beta$ ), trealose e sacarose não foram hidrolisados (Tabela 11). As enzimas amilolíticas do extrato bruto obtido sob condições ótimas de cultivo foram aplicadas a uma solução de amido $1 \%$ e os produtos de hidrólise foram analisados por TLC (Figura 10). Foi possível observar depois de 60 minutos de reação que glicose e maltose foram acumulados sugerindo a presença concomitante de $\alpha$ amilase e glucoamilase.

Os extratos enzimáticos com atividade amilolítica proveniente de meios de cultivos suplementados com amido solúvel e casca de mandioca foram aplicados em gel de eletroforese (PAGE) não desnaturante conforme mostra a Figura 11. Foi possível verificar a presença de múltiplas formas com atividade amilolítica. Este fenômeno é interessante porque estas diferentes formas enzimáticas atuam em distintos estágios na sacarificação do amido. 
Tabela 11: Atividade amilolítica em diferentes substratos

Substrato (1\%)

$(\%)$

Amido solúvel 100

Maltose 106

Amilose $\quad 88$

Amilopectina 46

Glicogênio $\quad 50$

Penetrose $\quad 100$

Maltotriose $\quad 70$

Isomaltose 86

Ciclodextrin $(\alpha$ e $\beta) \quad 0$

Trealose 0

Sacarose 0

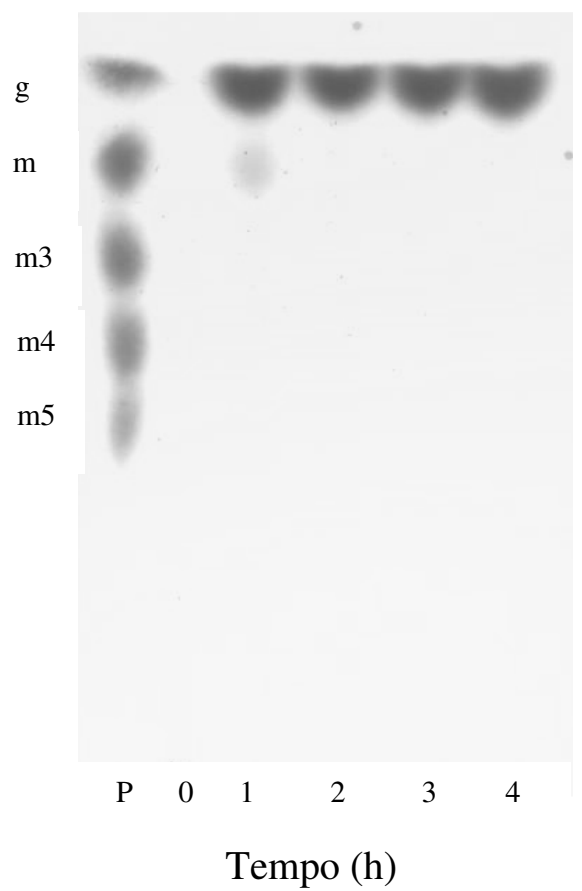

Figura 10: Análise dos produtos de hidrólise do amido a 1\% em diferentes tempos $(0,1,2,3$ e 4 horas). $\mathrm{O}$ fungo foi cultivado em condição estática a $35^{\circ} \mathrm{C}$ por 48 horas; g: $1 \%(\mathrm{w} / \mathrm{v})$ glucose, $\mathrm{m}: 1 \%(\mathrm{w} / \mathrm{v})$ maltose, $\mathrm{m} 3: 1 \%(\mathrm{w} / \mathrm{v})$ maltotriose, $\mathrm{m} 4: 1 \%(\mathrm{w} / \mathrm{v})$ maltotetraose, $\mathrm{m} 5$ : $1 \%(\mathrm{w} / \mathrm{v})$ maltopentaose e P-padrões. 


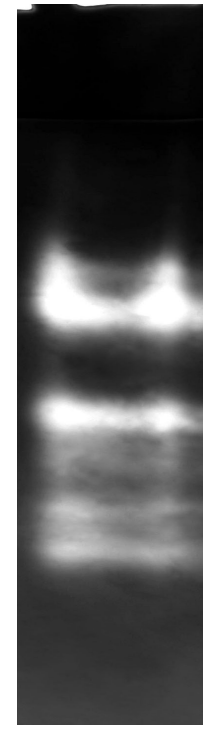

(A)

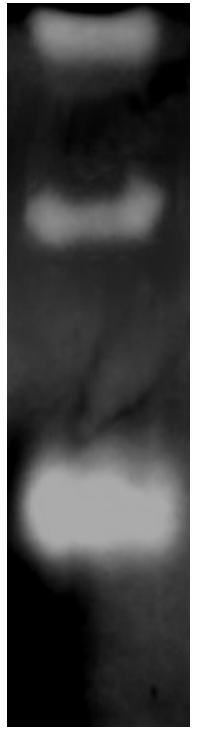

(B)

Figura 11: Atividade amilolítica em PAGE (5-10\%) contendo 1\% de amido solúvel. (A) extrato enzimático obtido em cultivo com casca de mandioca como fonte de carbono e (B) extrato enzimático obtido em cultivo com amido solúvel como fonte de carbono.

\subsection{4- Efeito do pH e temperatura na atividade amilolítica das enzimas} produzidas em meio com casca de mandioca

$\mathrm{O}$ pH ótimo de atividade das amilases foi determinado na faixa de 4,0-5,0 (figura 12 A). A atividade amilolítica de A. niveus foi alcalino-tolerante, permanecendo estável na faixa de pH entre 4,0 a 7,0 depois de 24 horas de incubação (Figura 12 B). A temperatura ótima para a atividade amilolítica foi de $70^{\circ} \mathrm{C}$ e as enzimas foram completamente estáveis durante 6 horas a $55^{\circ} \mathrm{C}$ e manteve $50 \%$ de atividade depois de incubada a $60^{\circ} \mathrm{C}$ por 4 horas (Figuras $12 \mathrm{C}$ e D). 

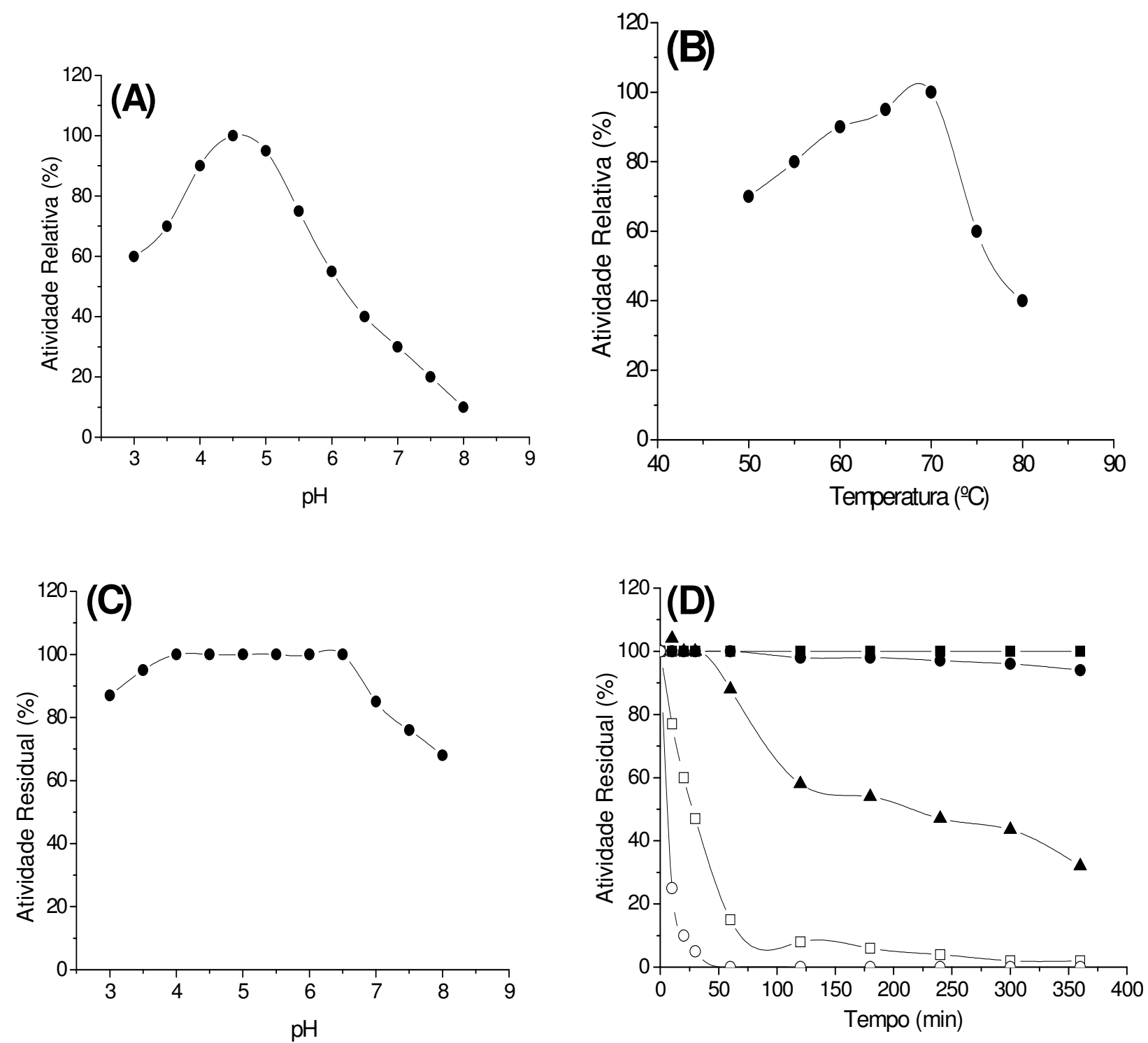

Figura 12: Influencia do $\mathrm{pH}$ e temperatura na atividade amilolítica A e B. Estabilidade em diferentes $\mathrm{pHs}$ C. Estabilidade em diferentes temperaturas em função do tempo D. Quadrado fechado $50^{\circ} \mathrm{C}$, circulo fechado $55^{\circ} \mathrm{C}$, triangulo fechado $60^{\circ} \mathrm{C}$, quadrado aberto $65^{\circ} \mathrm{C}$ e circulo aberto $70^{\circ} \mathrm{C}$.

\subsection{6- Ensaios de purificação das amilases produzidas em meio com amido solúvel como fonte indutora}

Um volume de $100 \mathrm{~mL}$ de extrato enzimático bruto obtido em condições ideais de cultivo, dializado contra água destilada por aproximadamente 20 horas, a $4^{\circ} \mathrm{C}$, foi aplicado em 
coluna de troca iônica DEAE-fractogel (Figura 13A). Após a eluição, 2 picos de atividade amilásica foram detectados, o pico I que não aderiu a resina e o pico II que foi retido na mesma, e que, posteriormente, foi eluído com um gradiente linear de $\mathrm{NaCl}(0-0,5 \mathrm{M})$. As frações referentes ao pico I foram reunidas em um "pool”, para determinação de atividade e em seguida ser aplicado em coluna cromatográfica de afinidade Concanavalina A-Sepharose (Figura 13B). A atividade especifica após eluição em DEAE-fractogel passou de 237 para 356 U/mg de proteínas e a recuperação foi de $87 \%$ (Tabela 12). Após ser aplicada em Concanavalina A-Sepharose (Figura 13B), a atividade amilolítica foi eluída em um gradiente linear de metil- $\alpha$-D-manopiranosideo $(0-0.5 \mathrm{M})$. As frações contendo o pico de atividade enzimática foram reunidas em um "pool”, posteriormente dializado e liofilizado para aplicação em géis de SDS-PAGE e PAGE para análise de pureza e caracterização bioquímica. Um volume final de $26 \mathrm{~mL}$ foi coletado e a atividade específica passou de 356 para $594 \mathrm{U} / \mathrm{mg}$ de proteínas. A recuperação foi de 47,5\% e o fator de purificação foi de 2,5 (Tabela 12).
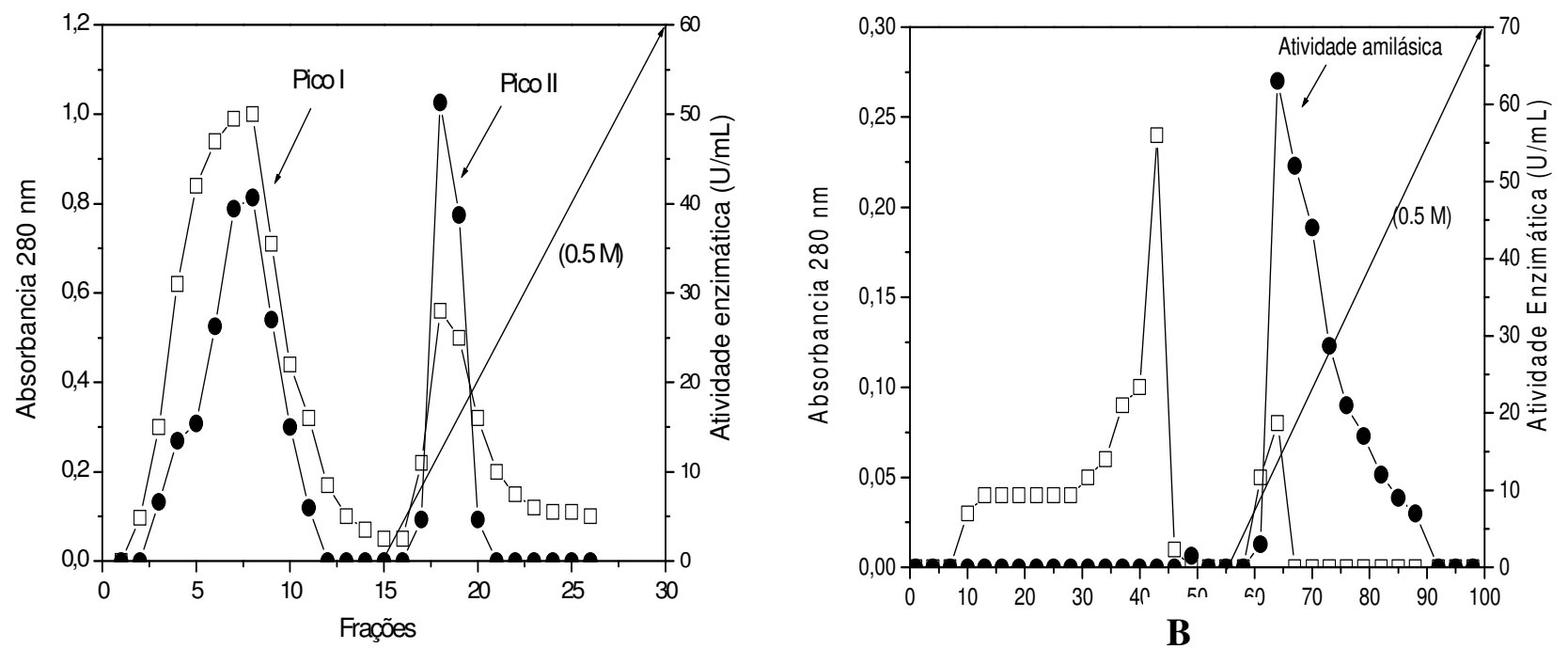

Figura 13: Distribuição de proteínas $(\square)$ e atividade amilásica $(\bullet)$ do extrato após eluição em cromatografia de troca iônica DEAE-fractogel (A) e Concanavalina A-Sepharose (B). ( _ ) gradiente de $\mathrm{NaCl}$ e metil- $\alpha$-D-manopiranosideo. 
Tabela 12: Purificação da glucoamilase produzida por $A$. niveus em fermentação submersa.

\begin{tabular}{ccccccc}
\hline \hline Procedimentos & $\begin{array}{c}\text { Volume } \\
\text { total } \\
(\mathbf{m L})\end{array}$ & $\begin{array}{c}\text { Proteínas } \\
(\mathbf{m g} \text { total })\end{array}$ & $\begin{array}{c}\text { Atividade } \\
\text { amilolítica } \\
\text { total }\end{array}$ & $\begin{array}{c}\text { Atividade } \\
\text { Específica } \\
\text { (U/mg proteína) }\end{array}$ & $\begin{array}{c}\text { Recuperação } \\
(\mathbf{\%})\end{array}$ & $\begin{array}{c}\text { Fator de } \\
\text { purificação }\end{array}$ \\
Extrato Bruto & 100,0 & 19,0 & 4500,0 & 237,0 & 100,0 & 1,0 \\
$\begin{array}{c}\text { DEAE-fractogel } \\
\text { (Pico I) }\end{array}$ & 80,0 & 11,0 & 3920,0 & 356,0 & 87,0 & 1,50 \\
Concanavalina & 26,0 & 3,94 & 2340,0 & 594,0 & 47,5 & 2,50 \\
\hline \hline
\end{tabular}

As frações referentes ao pico II (Figura 13 A) foram reunidas em um "pool", posteriormente dialisado e liofilizado para aplicação em coluna cromatográfica de exclusão por massa molecular Sephacryl S-200. Após a eluição 2 picos com atividade amilolítica foram detectados (Figura 14). As frações contendo os picos de atividade enzimática foram reunidas em um "pool", posteriormente dialisado e liofilizado para aplicação em géis de SDS-PAGE e PAGE para análise de pureza e caracterização bioquímica. 


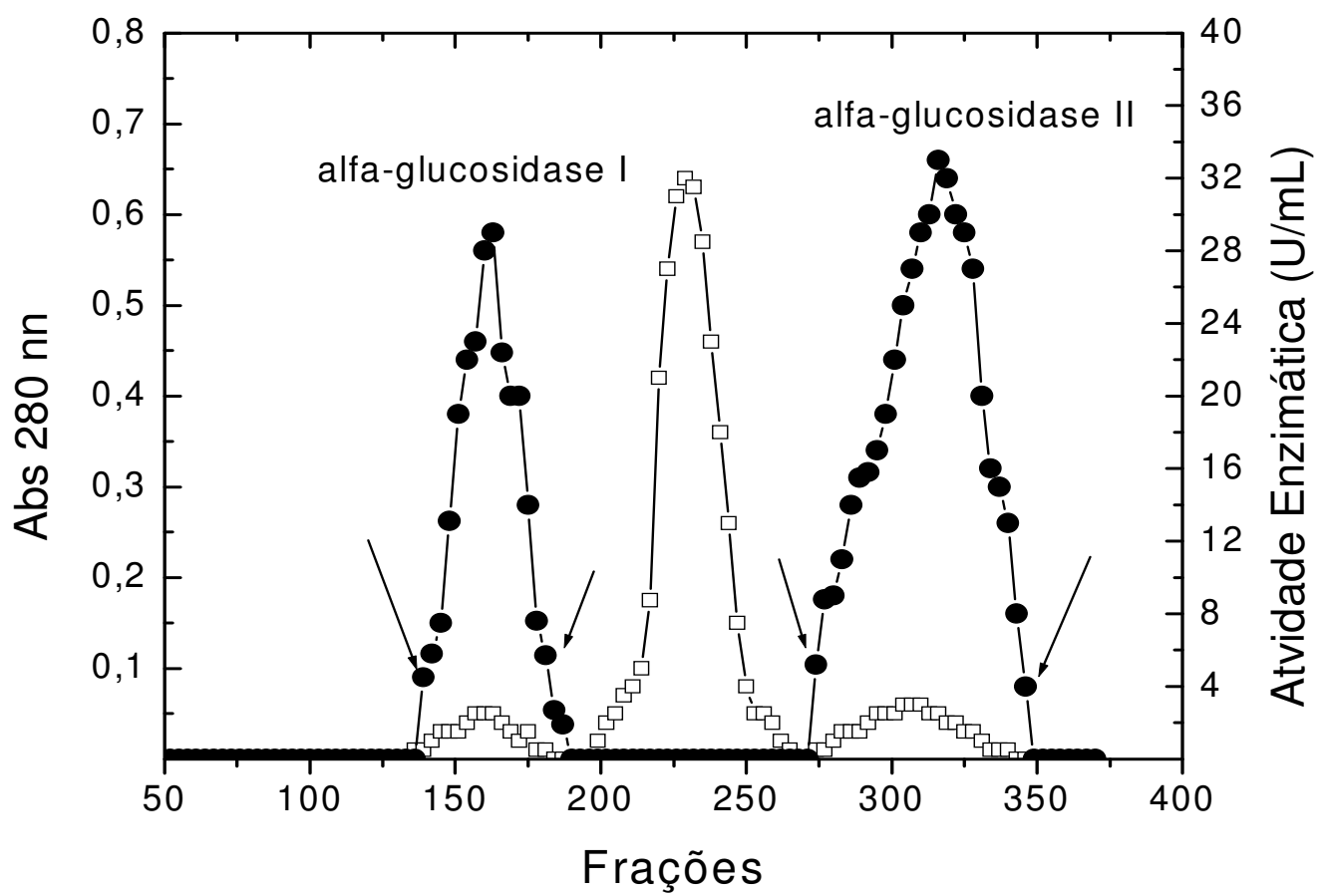

Figura 14: Distribuição de proteínas $(\square)$ e atividade amilásica $(\bullet)$ do extrato enzimático após eluição em cromatografia por filtração Sephacryl S-200.

Tabela 13: Purificação das $\alpha$-glucosidases I e II produzidas por $A$. niveus em fermentação submersa.

\begin{tabular}{lclllll}
\hline \hline Procedimentos & $\begin{array}{c}\text { Volume } \\
\text { total } \\
(\mathbf{m L})\end{array}$ & $\begin{array}{c}\text { Proteínas } \\
(\mathbf{m g} \text { total) }\end{array}$ & $\begin{array}{c}\text { Atividade } \\
\text { amilolítica } \\
\text { total }\end{array}$ & $\begin{array}{c}\text { Atividade } \\
\text { Específica } \\
\text { (U/mg } \\
\text { proteína) }\end{array}$ & $\begin{array}{c}\text { Recuperação } \\
(\mathbf{\%})\end{array}$ & $\begin{array}{c}\text { Fator de } \\
\text { purificação }\end{array}$ \\
\hline $\begin{array}{l}\text { Extrato } \\
\text { enzimático bruto }\end{array}$ & 100 & 97,0 & 10000 & 103,0 & 100 & 1 \\
$\begin{array}{l}\text { DEAE-Fractogel } \\
\text { (Pico II) }\end{array}$ & 22 & 8,7 & 1100 & 126,1 & 11,0 & 1,0 \\
$\begin{array}{l}\text { Sephacryl S-200 } \\
\text { (Pool I) }\end{array}$ & 20 & 1,2 & 360 & 321,4 & 3,6 & 2,6 \\
(Pool II) & 35 & 2,6 & 735 & 280,0 & 7,35 & 2,3 \\
\hline \hline
\end{tabular}


Após confirmar a pureza das enzimas, análises de produtos de hidrólise do amido, especificidade pelo substrato e sequenciamento de aminoácidos revelou que o pico I eluído em DEAE-Fractogel consiste em uma glucoamilase, e ambos os picos eluídos em Sephacryl S200 apresentaram-se como $\alpha$-glucosidase e, portanto, passaram então a ser chamadas de $\alpha$ glucosidase I e $\alpha$-glucosidase II. A atividade especifica do pico II após eluição em DEAEFractogel passou de $126,1 \mathrm{U} / \mathrm{mg}$ proteína para 321,4 e 280 para os picos I ( $\alpha$-glucosidase I) e II ( $\alpha$-glucosidase II) separados em Sephacryl S-200, e as recuperações foram de 3.6\% e 7.35\% para o $\alpha$-glucosidase I e $\alpha$-glucosidase II, respectivamente, em relação ao extrato bruto (Tabela $13)$.

\subsection{7- Eletroforese em condições desnaturante (SDS-PAGE), não desnaturante (PAGE) e determinação da massa molecular por cromatografia em gel filtração}

Após aplicação do extrato enzimático nas cromatografias de troca iônica e de filtração, foram feitas eletroforeses em condições desnaturante e não desnaturante, para avaliar o grau de pureza das enzimas e também estimar suas massas moleculares (Figuras 15, 16 e 17). As massas moleculares foram estimadas em $77 \mathrm{kDa}$ para glucoamilase (Figura $15 \mathrm{~A}$ ), $59 \mathrm{kDa}$ para $\alpha$-glucosidase I (Figura $16 \mathrm{~A}$ ) e $55 \mathrm{kDa}$ para $\alpha$-glucosidase II (Figura $17 \mathrm{~A}$ ). Outro procedimento utilizado na determinação da massa molecular das amilases foi a aplicação das enzimas purificadas em coluna de filtração. Utilizou-se para este procedimento, a coluna de filtração da Bio-Sil-Sec-400 da Bio-Rad. Através de uma reta padrão, estimou-se que as massas moleculares foram de $76 \mathrm{kDa}$ para (glucoamilase), $56 \mathrm{kDa}(\alpha$-glucosidase I) e $52 \mathrm{kDa}$ ( $\alpha$-glucosidase II) (Figuras 15 C, 16C e 17C). 


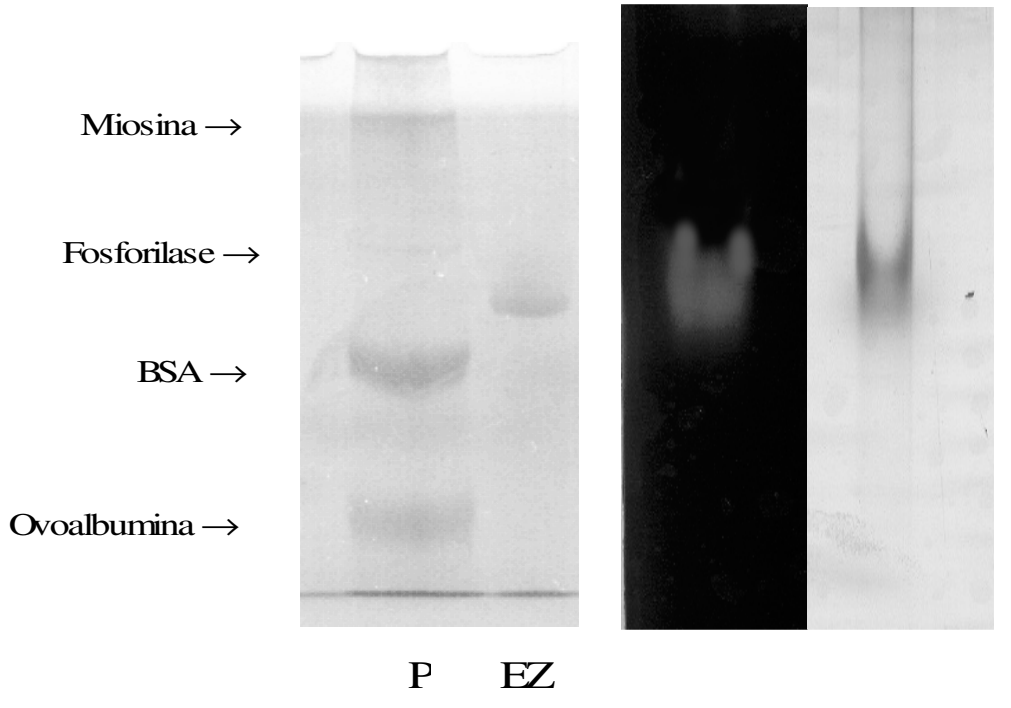

A
B

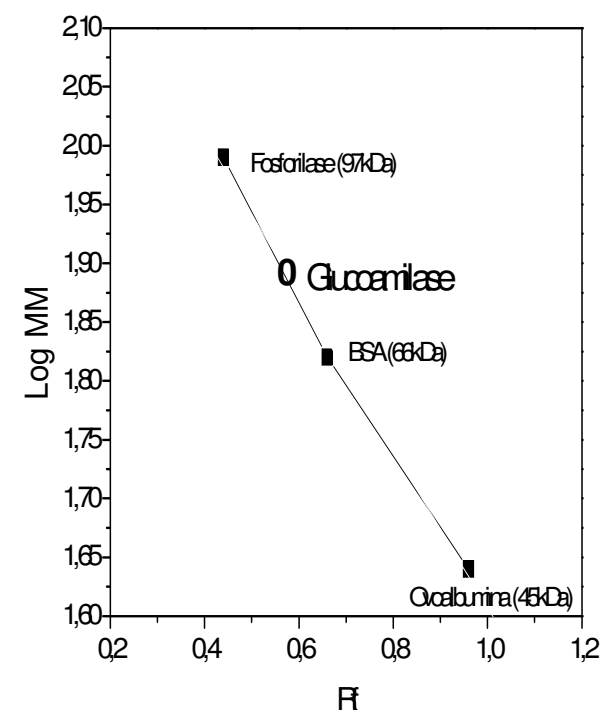

C.

Figura 15: Eletroforese e representação logarítmica da massa molecular da glucoamilase produzida por $A$. niveus. (A) SDS-PAGE 6\% corado com Comassie Brilhante Blue, (B) PAGE 5\% e (C) determinação da massa molecular em SDS-PAGE. Legenda: P- padrões, EZ- enzima purificada corada com Comassie Brilhante Blue. Miosina (205 kDa), fosforilase (97kDa), albumina de Soro Bovino (66 kDa) e ovoalbumina $(45 \mathrm{kDa})$. 


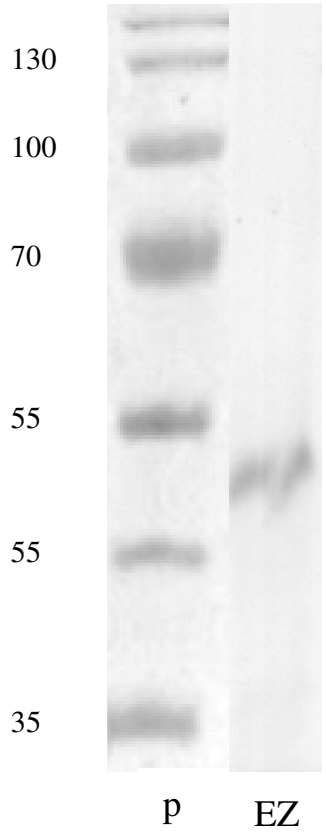

A

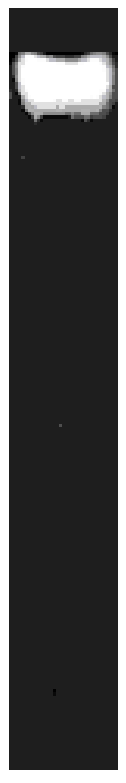

a

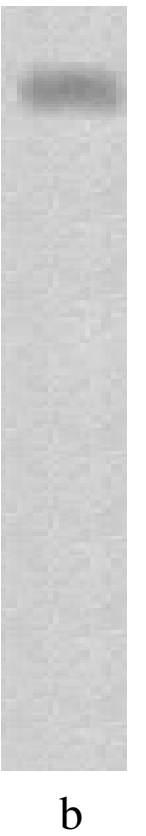

B

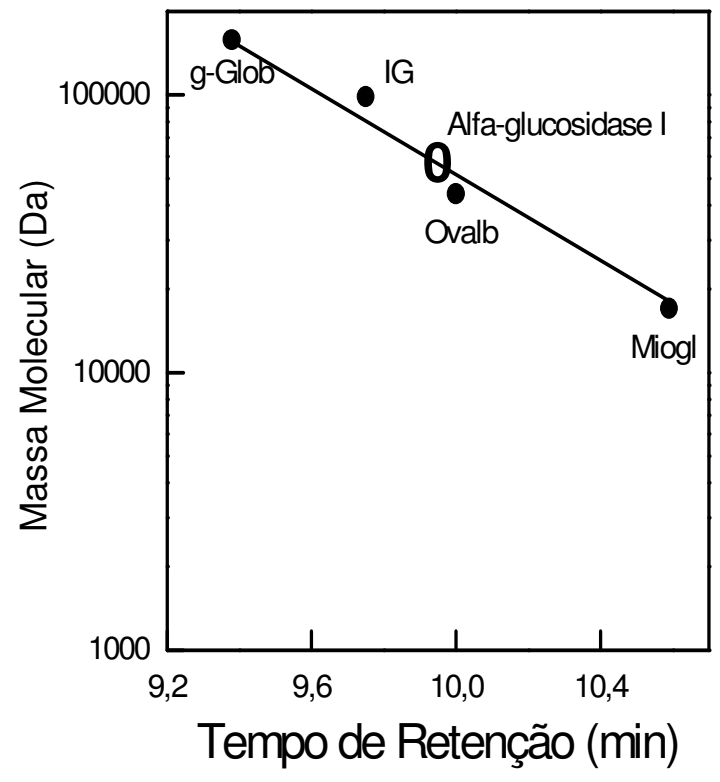

C

Figura 16: Eletroforese e representação logarítmica da massa molecular da $\alpha$-glucosidase I produzida por $A$. niveus. (A) SDS-PAGE 6\% corado com Comassie Brilhante Blue, (B) PAGE 5\% e (C) determinação da massa molecular em HPLC equipado com coluna de filtração (Bio-Sil-Sec-400). Legenda: P- padrões, EZ- enzima purificada corada com Comassie Brilhante Blue a- atividade enzimática em gel PAGE 5\% e b- Enzima purificada e corada com Comassie Brilhante Blue. Símbolos: globulina (325 kDa); IG-Imunoglobulina (158 $\mathrm{kDa}$ ); Ovalbumina (45 kDa); Mioglobina (17 kDa). 


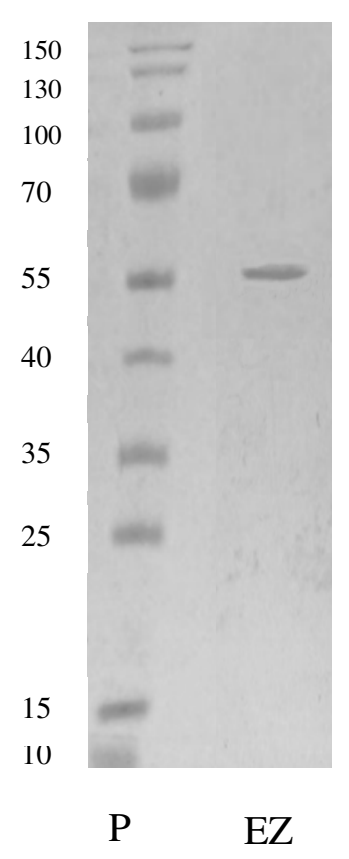

A

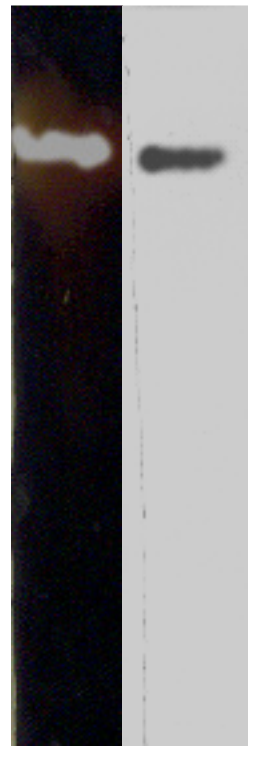

a b

b

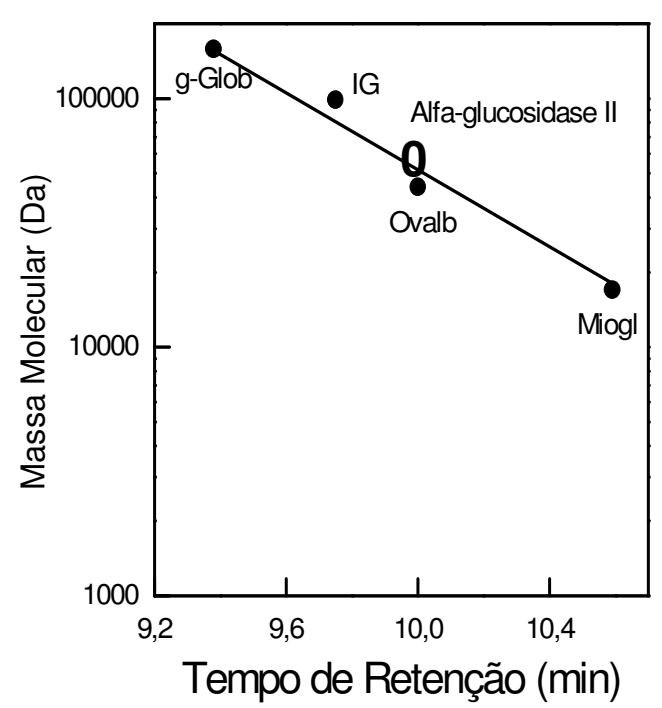

Figura 17: Eletroforese e representação logarítmica da massa molecular da $\alpha$-glucosidase II produzida por A. niveus. (A) SDS-PAGE 6\% corado com Comassie Brilhante Blue e (B) PAGE 5\% e (C) determinação da massa molecular de $\alpha$-glucosidase II em HPLC equipado com coluna de filtração (Bio-sil Sec-400).Legenda: P-padrões, EZ- enzima purificada, a- atividade enzimática em gel PAGE 5\% e b- Enzima purificada e corada com Comassie Brilhante Blue. Símbolos: globulina (325 kDa); IG-Imunoglobulina (158 kDa); Ovalbumina (45 kDa); Mioglobina (17 kDa).

\subsection{8- Determinação do conteúdo de carboidratos e ponto isoelétrico (pI)}

O conteúdo de carboidratos das amilases purificadas estimado através da metodologia do fenol-sulfúrico descrita por DUBOIS et al. (1956) foi de 15\% para glucoamilase, $4 \%$ para $\alpha$-glucosidase I e de $29 \%$ para $\alpha$-glucosidase II. O ponto isoelétrico (pI) das amilases purificadas de A. niveus, por focalização isoelétrica em gel de poliacrilamida, utilizando-se 
anfólito da PhamaLITE (Sigma) com gradiente de $\mathrm{pH}$ de 3,0 a 10 foi de 3,8 para glucoamilase, 6,6 para $\alpha$-glucosidase I e 6,8 para $\alpha$-glucosidase II (Figura 18).
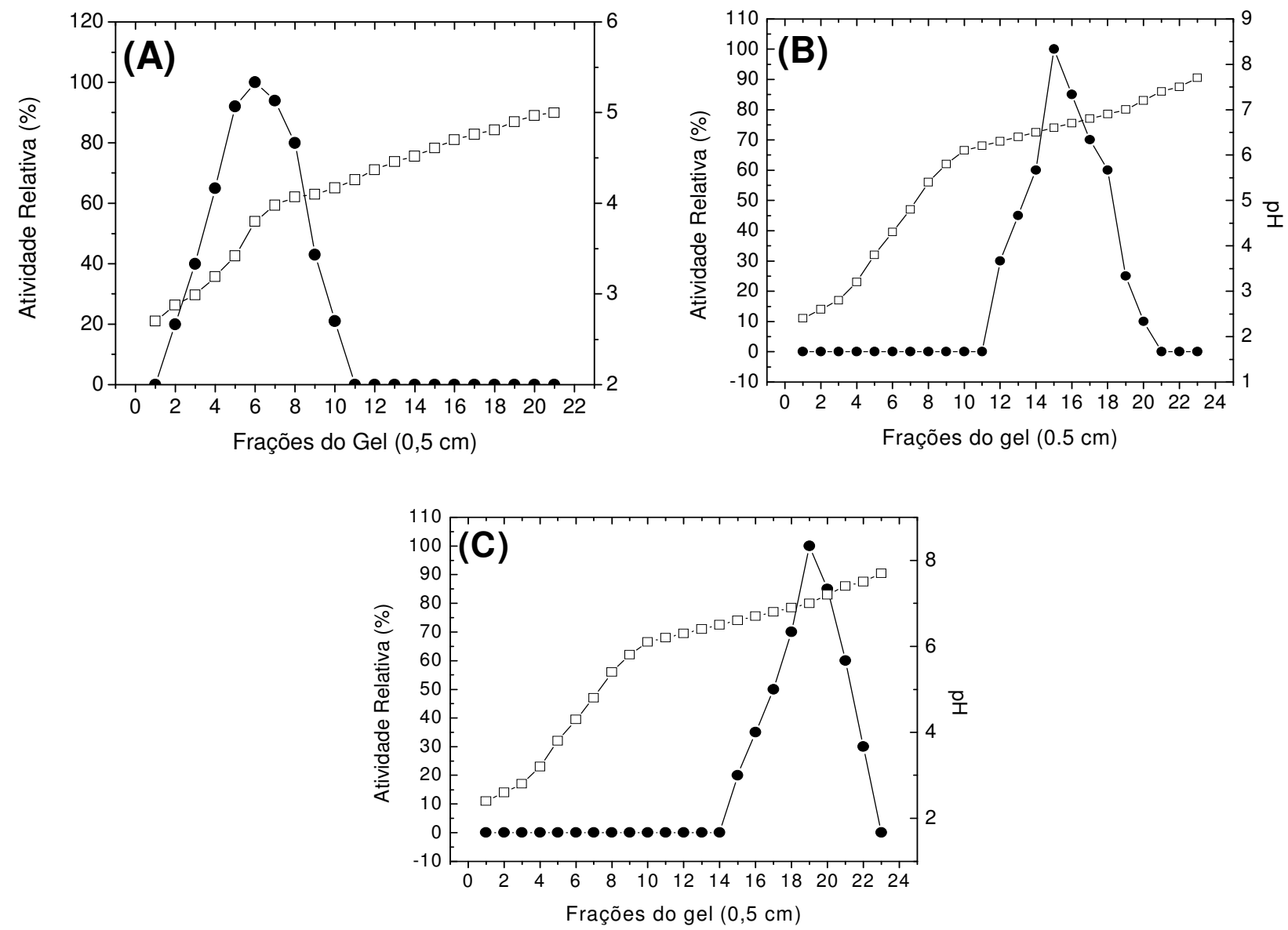

Figura 18: Representação gráfica da focalização isoelétrica (pI) das amilases extracelulares (A) glucoamilase (B) $\alpha$-glucosidase I e (C) $\alpha$-glucosidase II produzidas por A. niveus. Símbolos: ( ) gradiente de $\mathrm{pH}$ formado no gel polimerizado; $(\bullet)$ atividade enzimática.

\subsection{9- Efeito do $\mathrm{pH}$ e temperatura sobre a atividade e estabilidade das enzimas}

O pH ótimo para a atividade de glucoamilase foi de 5,0 e 5,5 (Figura 19 A). Já o pH ótimo de atividade tanto de $\alpha$-glucosidase I quanto da $\alpha$-glucosidase II foi de 6,0 (Figura $20 \mathrm{~A}$ e 21 A, respectivamente). A atividade enzimática das três enzimas foi também ácido-, alcalino-tolerante, mantendo-se estáveis por 2 horas em faixa de $\mathrm{pH}$ de 4,0 a 9,5 para 
glucoamilase (Figura 19B), 3,0 a 8,5 para $\alpha$-glucosidase I (Figura 20 B) e 4 a 8,5 para $\alpha$ glucosidase II (Figura 21 B). As três enzimas apresentaram temperatura ótima de atividade em $65^{\circ} \mathrm{C}$ (Figuras 19C, 20C e 21C). As enzimas apresentaram boa estabilidade, mantendo a glucoamilase com $50 \%$ de atividade após 360 minutos a $60^{\circ} \mathrm{C}$, a $\alpha$-glucosidase I $100 \%$ até 1 hora a $60^{\circ} \mathrm{C}$ e a $\alpha$-glucosidase II 3 horas nessa mesma temperatura (Figura 19D, 20D e 21D), fato este que reforça o potencial para a aplicação das amilases de A. niveus em processos que envolvem temperaturas elevadas. 


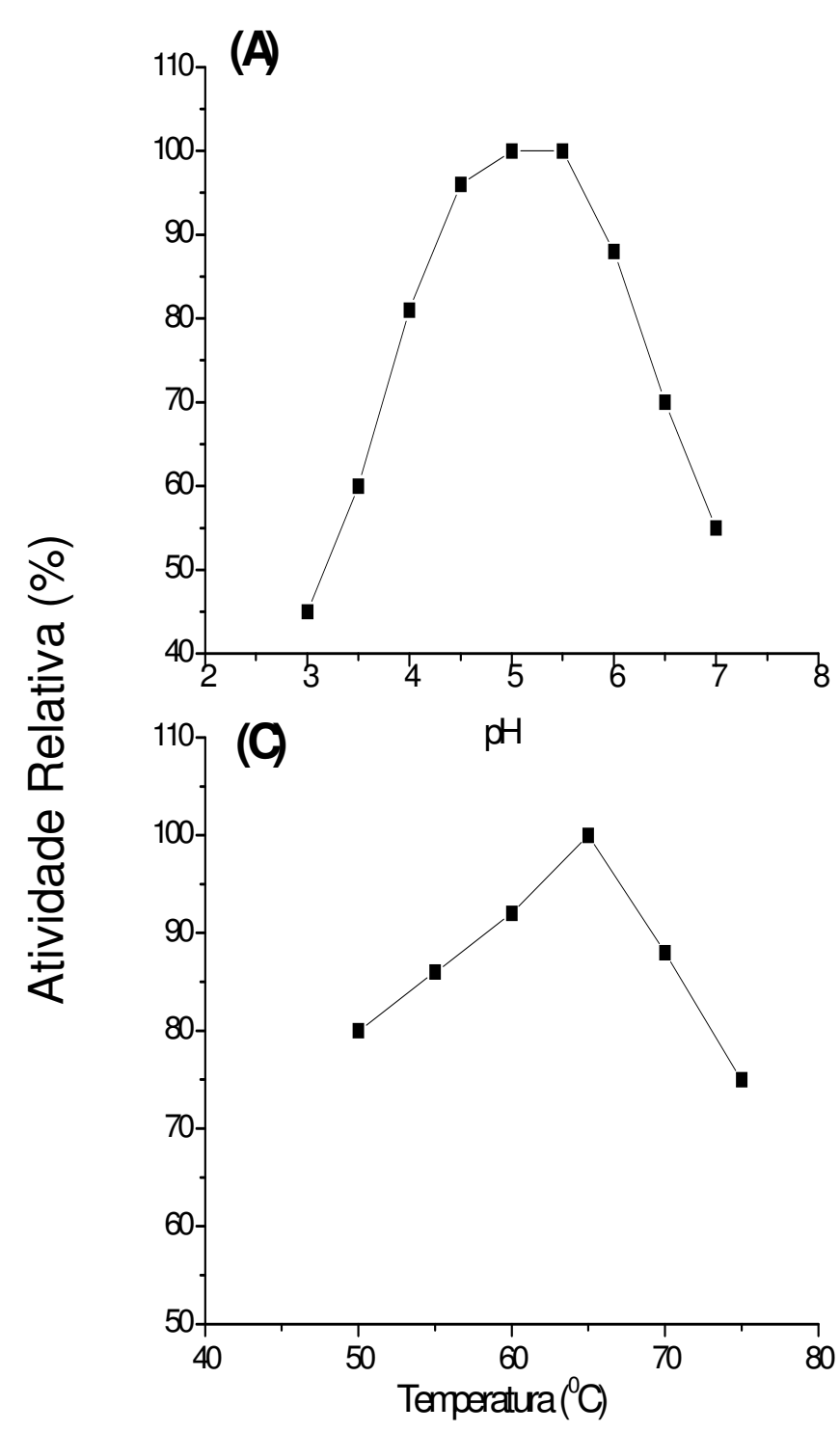

(B)
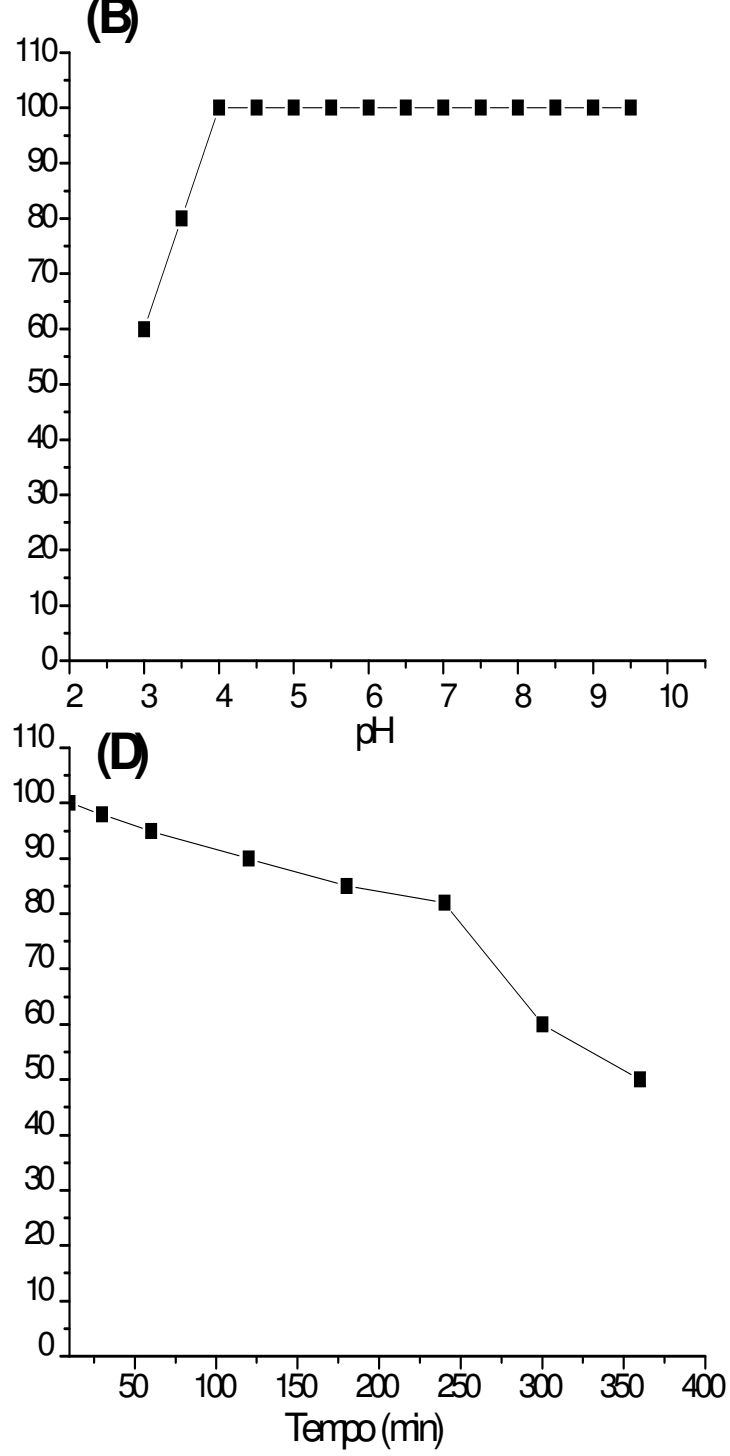

Figura 19: Efeito do $\mathrm{pH}$ e temperatura na atividade e estabilidade da glucoamilase. A- $\mathrm{pH}$ ótimo B- $\mathrm{pH}$ de estabilidade, $\mathbf{C}$ - temperatura ótima de atividade e $\mathbf{D}$ - estabilidade a $60^{\circ} \mathrm{C}$. 


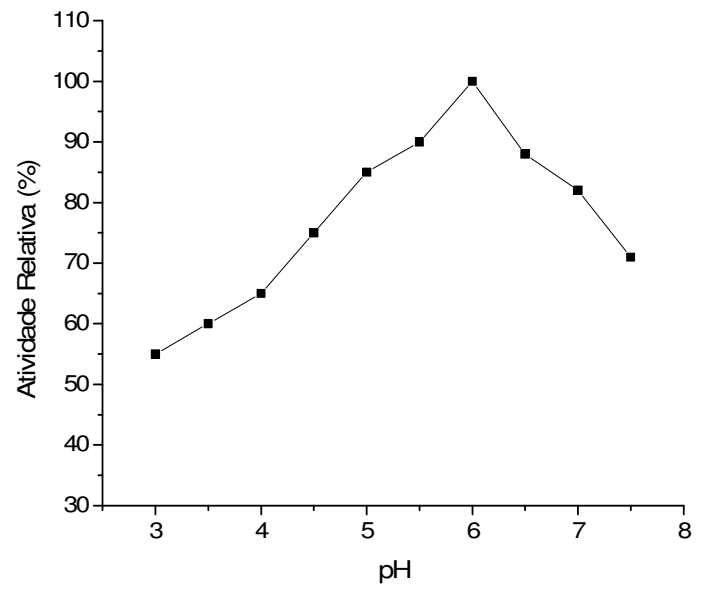

(A)

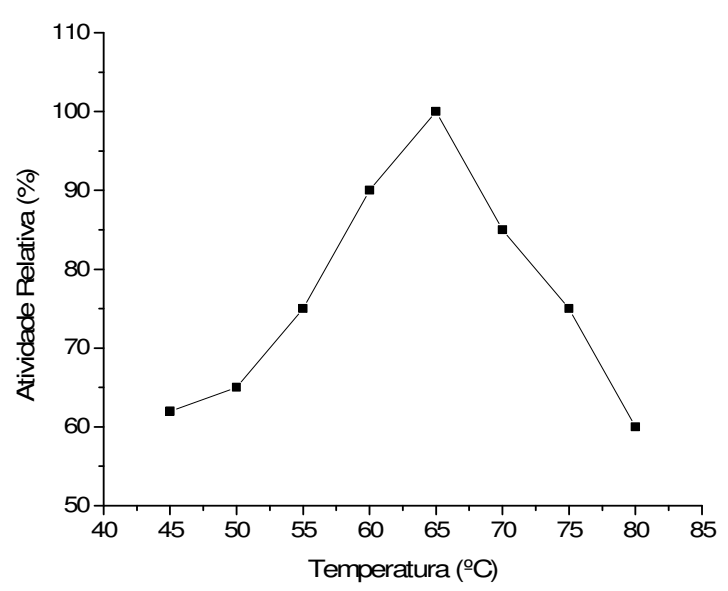

(C)

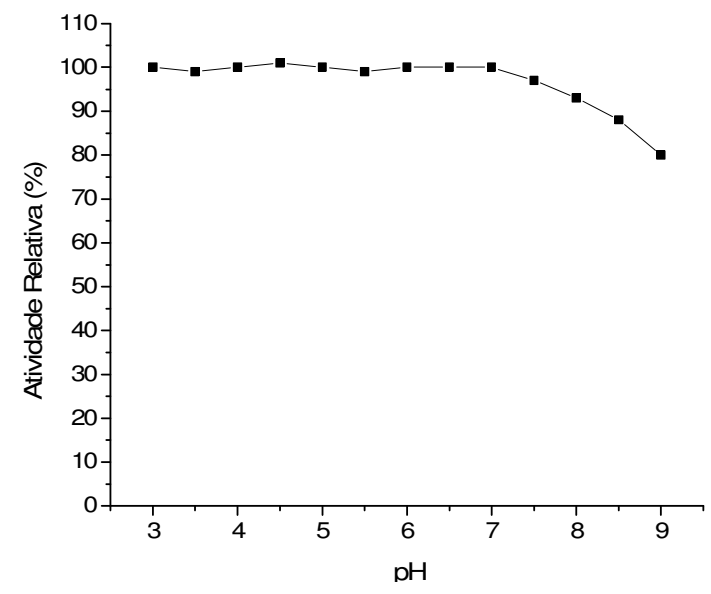

(B)

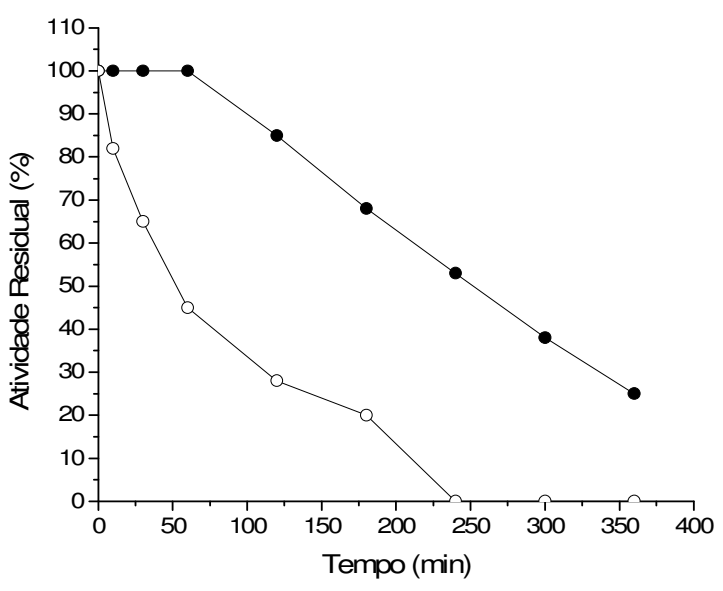

(D)

Figura 20: Efeito do pH e temperatura na atividade e estabilidade da $\alpha$-glucosidase I. A-pH ótimo B$\mathrm{pH}$ de estabilidade, $\mathbf{C}$ - temperatura ótima de atividade e $\mathbf{D}$ - estabilidade térmica. Legenda: $-\bullet-60^{\circ} \mathrm{C}$ e $-\mathrm{O}-65^{\circ} \mathrm{C}$. 


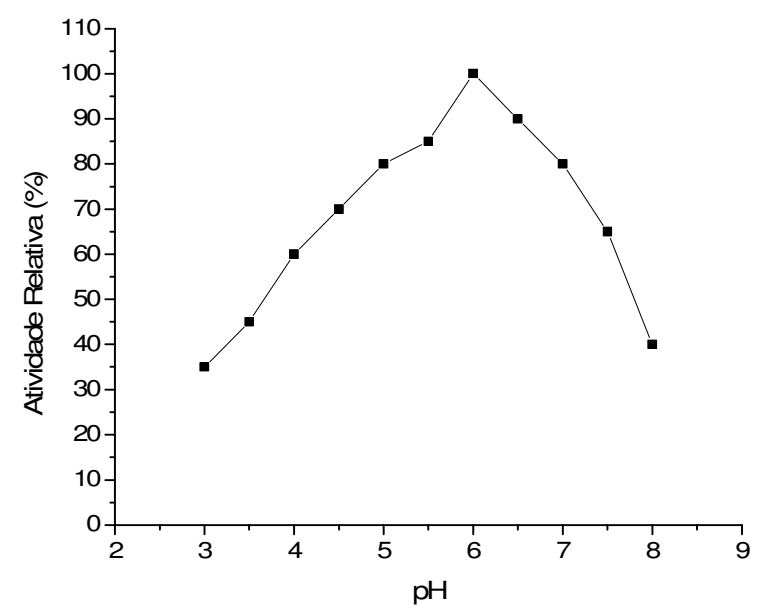

(A)

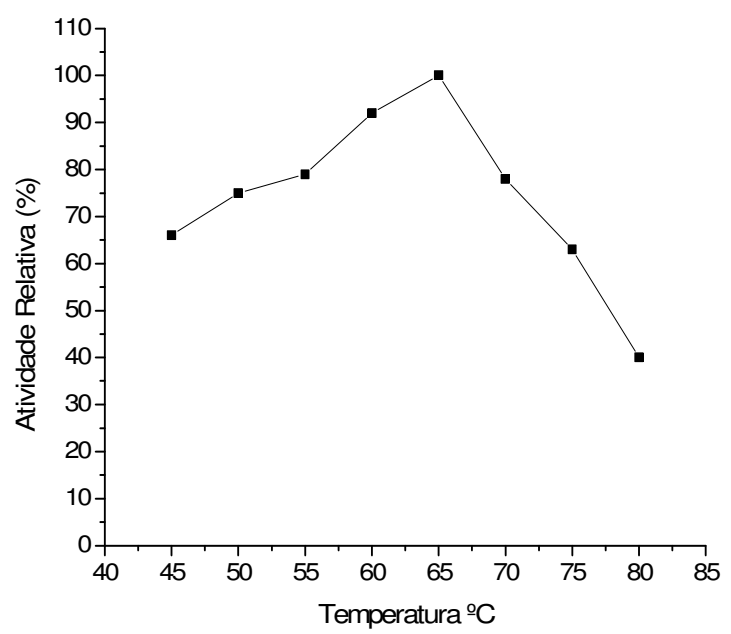

(C)

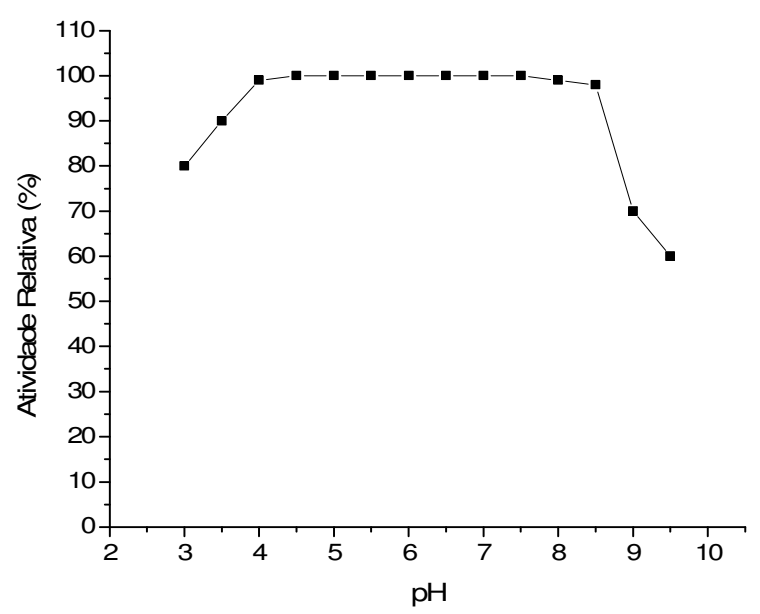

(B)

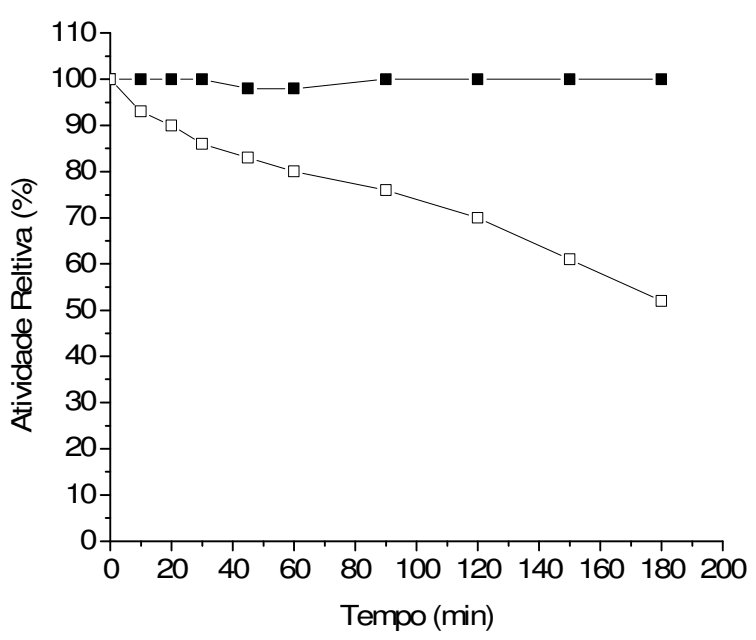

(D)

Figura 21: Efeito do pH e temperatura na atividade e estabilidade da $\alpha$-glucosidase II. A-pH ótimo B-pH de estabilidade, $\mathbf{C}$ - temperatura ótima de atividade e D- estabilidade térmica. Legenda: - $\bullet-60^{\circ} \mathrm{C}$ e - $-65^{\circ} \mathrm{C}$. 


\subsection{0- Efeito de íons, EDTA e $\beta$-mercaptoetanol sobre a atividade enzimática}

Dados da literatura têm mostrado que muitas amilases fúngicas são dependentes de alguns íons metálicos, os quais facilitam uma melhor interação entre o sítio catalítico da enzima com o seu respectivo substrato, conseqüentemente aumentando a formação do produto. A Glucoamilase mostrou uma pequena ativação pela maioria dos íons testados, em pequenas concentrações junto ao meio reacional (Tabela 14). Na concentração de 1,0 mM, todos os íons ativaram a enzima (5-35\%) exceto $\mathrm{Ag}^{+}$e $\mathrm{Fe}^{+2}$, que inibiram a atividade enzimática em 21 e 5\%, respectivamente. $\mathrm{Na}$ concentração de $10 \mathrm{mM}$ não foi observado grandes ativações. Os íons $\mathrm{Ag}^{+}$e $\mathrm{Fe}^{+2}$ inibiram a atividade em 49 e $48 \%$, respectivamente.

A $\alpha$-glucosidase I foi ativada em $17,14,80,28,39$ e $61 \%$ na presença de $1 \mathrm{mM}$ dos compostos $\mathrm{NH}_{4} \mathrm{~F}, \quad \mathrm{NaBr}, \quad \mathrm{MnCl}_{2} \cdot 4 \mathrm{H}_{2} \mathrm{O}, \quad \mathrm{NaH}_{2} \mathrm{PO}_{4} \mathrm{H}_{2} \mathrm{O}, \quad \mathrm{ZnCl}_{2}$ e $\beta$-mercaptoetanol, respectivamente. Na concentração de $10 \mathrm{mM}$, a atividade de $\alpha$-amilase foi maior em 23,20 , 16, 12 e $16 \%$ com a presença dos compostos $\mathrm{NH}_{4} \mathrm{~F}, \mathrm{KH}_{2} \mathrm{PO}_{4}, \mathrm{NH}_{4} \mathrm{Cl}, \mathrm{NaCl}$, e $\mathrm{CoCl}_{2} \cdot 6 . \mathrm{H}_{2} \mathrm{O}$, respectivamente. Os compostos $\mathrm{HgCl}_{2}, \mathrm{AgNO}_{3}$ e $\mathrm{Fe}_{2}\left(\mathrm{SO}_{4}\right)$ inibiram drasticamente a atividade de $\alpha$-amilase na concentração de $10 \mathrm{mM}$ (Tabela 15).

A atividade de $\alpha$-glucosidase II não sofreu alteração significativa com a presença dos íons. Um aumento de $20 \%$ na atividade foi evidenciado na presença do composto $\mathrm{Pb}\left(\mathrm{C}_{2} \mathrm{H}_{3} \mathrm{O}_{2}\right)_{2} \cdot 3 \mathrm{H}_{2} \mathrm{O}$, na concentração de $10 \mathrm{mM}$. Assim como a $\alpha$-glucosidase I a presença dos íons $\mathrm{AgNO}_{3}$ e $\mathrm{Fe}_{2}(\mathrm{SO} 4)$ na concentração de $10 \mathrm{mM}$ inibiram drasticamente a atividade enzimática (Tabela 16). $\mathrm{O}$ efeito do $\beta$-mercaptoetanol e $\mathrm{HgCl}_{2}$, foi muito diferente na concentração de $10 \mathrm{mM}$ entre as duas enzimas. A presença de $10 \mathrm{mM}$ de $\beta$-mercaptoetanol não interferiu na atividade da $\alpha$-glucosidase I e por outro lado até aumentou em $60 \%$ na concentração de $1 \mathrm{mM}$. Em contraste, inibiu drasticamente a atividade da $\alpha$-glucosidase II. $\mathrm{O}$ 
contrário pode ser observado para $\mathrm{o} \mathrm{HgCl}_{2}$ que em $10 \mathrm{mM}$ inibiu muito a atividade de $\alpha$ glucosidase I e não provocou proporcionou alteração a atividade da $\alpha$-glucosidase II.

Tabela 14: Efeito de diferentes íons, EDTA e $\beta$-mercaptoetanol, sobre a atividade enzimática da glucoamilase.

\begin{tabular}{|c|c|c|}
\hline \multirow[t]{2}{*}{ Íons } & \multicolumn{2}{|c|}{ Atividade relativa (\%) } \\
\hline & $1 \mathrm{mM}$ & $10 \mathrm{mM}$ \\
\hline Controle & 100 & 100 \\
\hline $\mathrm{CaCl}_{2}$ & 112 & 128 \\
\hline $\mathrm{BaCl}_{2}$ & 112 & 106 \\
\hline $\mathrm{NH}_{4} \mathrm{~F}$ & 105 & 112 \\
\hline $\mathrm{NaBr}$ & 122 & 109 \\
\hline $\mathrm{KH}_{2} \mathrm{PO}_{4}$ & 115 & 106 \\
\hline $\mathrm{MnCl}_{2} \cdot 4 \mathrm{H}_{2} \mathrm{O}$ & 115 & 88 \\
\hline $\mathrm{MgCl}_{2} \cdot 6 \mathrm{H}_{2} \mathrm{O}$ & 111 & 97 \\
\hline $\mathrm{HgCl}_{2}$ & 126 & 70 \\
\hline $\mathrm{Pb}\left(\mathrm{C}_{2} \mathrm{H}_{3} \mathrm{O}_{2}\right)_{2} .3 \mathrm{H}_{2} \mathrm{O}$ & 111 & 83 \\
\hline $\mathrm{NH}_{4} \mathrm{Cl}$ & 124 & 118 \\
\hline $\mathrm{CuCl}_{2}$ & 128 & 115 \\
\hline $\mathrm{KCl}$ & 105 & 95 \\
\hline $\mathrm{NaCl}$ & 135 & 105 \\
\hline EDTA & 100 & 94 \\
\hline $\mathrm{NaH}_{2} \mathrm{PO}_{4} \mathrm{H}_{2} \mathrm{O}$ & 117 & 117 \\
\hline$\beta$-mercaptoetanol & 114 & 100 \\
\hline $\mathrm{CoCl}_{2} \cdot 6 \cdot \mathrm{H}_{2} \mathrm{O}$ & 116 & 122 \\
\hline $\mathrm{AgNO}_{3}$ & 79 & 51 \\
\hline $\mathrm{Fe}\left(\mathrm{SO}_{4}\right)$ & 95 & 52 \\
\hline $\mathrm{ZnCl}_{2}$ & 114 & 88 \\
\hline
\end{tabular}

O controle corresponde ao ensaio enzimático sem adição de qualquer composto citado na tabela. 
Tabela 15: Efeito de diferentes íons, EDTA e $\beta$-mercaptoetanol, sobre a atividade de $\alpha$-glucosidase $I$.

\begin{tabular}{|c|c|c|}
\hline \multirow[t]{2}{*}{ Compostos } & \multicolumn{2}{|c|}{ Atividade relativa $(\%)$} \\
\hline & $1 \mathrm{mM}$ & $10 \mathrm{mM}$ \\
\hline Controle & 100 & 100 \\
\hline $\mathrm{CaCl}_{2}$ & 109 & 109 \\
\hline $\mathrm{BaCl}_{2}$ & 100 & 95 \\
\hline $\mathrm{NH}_{4} \mathrm{~F}$ & 117 & 123 \\
\hline $\mathrm{NaBr}$ & 114 & 112 \\
\hline $\mathrm{KH}_{2} \mathrm{PO}_{4}$ & 100 & 120 \\
\hline $\mathrm{MnCl}_{2} \cdot 4 \mathrm{H}_{2} \mathrm{O}$ & 180 & 144 \\
\hline $\mathrm{MgCl}_{2} \cdot 6 \mathrm{H}_{2} \mathrm{O}$ & 108 & 114 \\
\hline $\mathrm{HgCl}_{2}$ & 100 & 10 \\
\hline $\mathrm{Pb}\left(\mathrm{C}_{2} \mathrm{H}_{3} \mathrm{O}_{2}\right)_{2} .3 \mathrm{H}_{2} \mathrm{O}$ & 100 & 90 \\
\hline $\mathrm{NH}_{4} \mathrm{Cl}$ & 107 & 116 \\
\hline $\mathrm{CuCl}_{2}$ & 100 & 92 \\
\hline $\mathrm{KCl}$ & 106 & 110 \\
\hline $\mathrm{NaCl}$ & 100 & 112 \\
\hline EDTA & 100 & 110 \\
\hline $\mathrm{NaH}_{2} \mathrm{PO}_{4} \mathrm{H}_{2} \mathrm{O}$ & 128 & 111 \\
\hline$\beta$-mercaptoetanol & 161 & 100 \\
\hline $\mathrm{CoCl}_{2} \cdot 6 \mathrm{H}_{2} \mathrm{O}$ & 100 & 116 \\
\hline $\mathrm{AgNO}_{3}$ & 70 & 46 \\
\hline $\mathrm{Fe}_{2}\left(\mathrm{SO}_{4}\right)$ & 90 & 55 \\
\hline $\mathrm{ZnCl}_{2}$ & 139 & 100 \\
\hline
\end{tabular}

O controle corresponde ao ensaio enzimático sem adição de qualquer composto citado na tabela. 
Tabela 16: Efeito de diferentes íons, EDTA e $\beta$-mercaptoetanol, sobre a atividade de $\alpha$-glucosidase II.

\begin{tabular}{|c|c|c|}
\hline \multirow[t]{2}{*}{ Compostos } & \multicolumn{2}{|c|}{ Atividade relativa $(\%)$} \\
\hline & $1 \mathrm{mM}$ & $10 \mathrm{mM}$ \\
\hline Controle & 100 & 100 \\
\hline $\mathrm{CaCl}_{2}$ & 94 & 97 \\
\hline $\mathrm{BaCl}_{2}$ & 98 & 98 \\
\hline $\mathrm{NH}_{4} \mathrm{~F}$ & 98 & 100 \\
\hline $\mathrm{NaBr}$ & 97 & 94 \\
\hline $\mathrm{KH}_{2} \mathrm{PO}_{4}$ & 93 & 97 \\
\hline $\mathrm{MnCl}_{2} \cdot 4 \mathrm{H}_{2} \mathrm{O}$ & 100 & 105 \\
\hline $\mathrm{MgCl}_{2} \cdot 6 \mathrm{H}_{2} \mathrm{O}$ & 100 & 100 \\
\hline $\mathrm{HgCl}_{2}$ & 97 & 98 \\
\hline $\mathrm{Pb}\left(\mathrm{C}_{2} \mathrm{H}_{3} \mathrm{O}_{2}\right)_{2} \cdot 3 \mathrm{H}_{2} \mathrm{O}$ & 100 & 120 \\
\hline $\mathrm{NH}_{4} \mathrm{Cl}$ & 96 & 94 \\
\hline $\mathrm{CuCl}_{2}$ & 100 & 100 \\
\hline $\mathrm{KCl}$ & 100 & 100 \\
\hline $\mathrm{NaCl}$ & 100 & 100 \\
\hline EDTA & 100 & 100 \\
\hline $\mathrm{NaH}_{2} \mathrm{PO}_{4} \cdot \mathrm{H}_{2} \mathrm{O}$ & 100 & 100 \\
\hline$\beta$-mercaptoetanol & 100 & 14 \\
\hline $\mathrm{CoCl}_{2} \cdot 6 \cdot \mathrm{H}_{2} \mathrm{O}$ & 110 & 96 \\
\hline $\mathrm{AgNO}_{3}$ & 70 & 35 \\
\hline $\mathrm{Fe}_{2}\left(\mathrm{SO}_{4}\right)$ & 76 & 40 \\
\hline $\mathrm{ZnCl}_{2}$ & 100 & 100 \\
\hline
\end{tabular}

O controle corresponde ao ensaio enzimático sem adição de qualquer composto citado na tabela. 


\subsection{1- Efeito da adição de solventes orgânicos sobre a atividade enzimática das amilases purificadas}

Esta etapa do trabalho consistiu em avaliar o efeito de alguns solventes orgânicos em concentrações de 5 e 10\%, no meio reacional sobre a atividade das enzimas purificadas. Os resultados são mostrados na Tabela 17 . Os solventes acetato de etila, álcool n-butílico e formol diminuíram a atividade relativa da glucoamilase em todas as concentrações testadas. Álcool isopropílico e etanol interferiram na atividade enzimática na partir da concentração de $10 \%$. Tolueno e benzeno não interferiram na atividade da enzima em nenhuma das concentrações testadas. A $\alpha$-glucosidase I resistiu à maioria dos solventes na concentração de $5 \%$, com exceção de álcool n-butílico, formol e acetona que inibiram a atividade enzimática em 19, 59 e $12 \%$, respectivamente. $\mathrm{Na}$ concentração de $10 \%$ quase todos os solventes inibiram parcialmente a atividade da $\alpha$-glucosidase I, com exceção do tolueno, benzeno e hexano. A $\alpha$ glucosidase II foi estável na presença dos solventes etanol, metanol, tolueno, benzeno e acetona, hexano a $5 \%$. Na concentração de $10 \%$, a $\alpha$-glucosidase II foi resistente a benzeno e acetona. 
Tabela 17: Efeito de solventes orgânicos na atividade das amilases de $A$. niveus.

\begin{tabular}{ccccccc}
\hline \hline Solvente & \multicolumn{2}{c}{$\begin{array}{c}\text { Glucoamilase } \\
\text { atividade Relativa }\end{array}$} & $\begin{array}{c}\alpha \text {-glucosidase I } \\
\text { atividade relativa }\end{array}$ & \multicolumn{2}{c}{$\begin{array}{c}\alpha \text {-glucosidase II } \\
\text { atividade reltiva }\end{array}$} \\
& $\mathbf{5 \%}(\mathbf{v} / \mathbf{v})$ & $\mathbf{1 0 \%}(\mathbf{v} / \mathbf{v})$ & $\mathbf{5 \%}(\mathbf{v} / \mathbf{v})$ & $\mathbf{1 0 \%}(\mathbf{v} / \mathbf{v})$ & $\mathbf{5 \%}(\mathbf{v} / \mathbf{v})$ & $\mathbf{1 0 \%}(\mathbf{v} / \mathbf{v})$ \\
\hline Controle & 100 & 100 & 100 & 100 & 100 & 100 \\
Acetato de Etila & 9 & 0 & 100 & 58 & 94 & 24 \\
Álcool n-Butílico & 79 & 30 & 81 & 87 & 55 & 35 \\
Álcool Isopropílico & 100 & 86 & 105 & 85 & 92 & 43 \\
Etanol & 100 & 86 & 103 & 89 & 100 & 74 \\
Formol & 53 & 0 & 41 & 0 & 47 & 0 \\
Metanol & 100 & 100 & 100 & 88 & 100 & 72 \\
Tolueno & 100 & 100 & 124 & 108 & 100 & 66 \\
Benzeno & 100 & 100 & 116 & 114 & 104 & 126 \\
Acetona & 116 & 100 & 88 & 88 & 100 & 103 \\
Hexano & 108 & 100 & 112 & 106 & 100 & 87 \\
\hline \hline
\end{tabular}

\subsection{2- Hidrólise de diferentes substratos pelas amilases purificadas}

Para a avaliação da especificidade ao substrato pelas amilase purificadas foram usados os seguintes substratos: amido Reagen (controle), amido Sigma, amilose, amilopectina, glicogênio, maltose, maltotriose, $\alpha$ e $\beta$-ciclodextrinas, trealose, sacarose, celobiose e os substratos sintéticos $\alpha$-pNPG, $\beta$-pNPG e p-nitrofenil- $\alpha$-D-maltosideo para glucoamilase e amido solúvel, amilose, amilopectina, maltose, maltotriose, maltotetraose, maltopentaose, isomaltose, maltooligossacarídeo, glicogênio, sacarose, trealose, $\alpha$-ciclodextrina, $\beta$ ciclodextrina, $\rho$-nitrofenil- $\beta$-pentaosideo e $\alpha$-pNPG para $\alpha$-glucosidase I e $\alpha$-glucosidase II e os resultados são mostrados na Figura 22 e Tabela 18. O substrato mais susceptível à ação das glucoamilase foi o amido Sigma com um aumento em $10 \%$ de produtos liberados em relação ao controle. A enzima mostrou excelente habilidade em degradar o glicogênio, amilopectina, 
maltotriose e maltose, tendo uma atividade relativa de 100, 74, 74 e $68 \%$, respectivamente. A atividade residual apresentada quando amilose foi o substrato correspondeu a apenas $20 \%$. Não foi observada atividade residual na presença de $\alpha$ e $\beta$-ciclodextrinas, trealose, sacarose, celobiose, $\alpha$-PNPG, $\beta$-PNPG e p-nitrofenil- $\alpha$-D-maltosideo.

O substrato mais susceptível à ação da $\alpha$-glucosidase I foi o glicogenio, seguido de, maltopentaose, maltotriose, amido solúvel, amilopectina, amilose, maltotetraose, maltose,maltooligossacarídeo G10, e isomaltose. Os demais substratos não foram hidrolisados (Tabela 18). A $\alpha$-glucosidase II apresentou maior afinidade pela maltopentaose, seguido de glicogênio, maltooligossacarídeo (G10) e amido solúvel. A enzima também hidrolisou com eficiência amilose, amilopectina, maltotetraose, maltotriose e maltose. Os substratos $\beta$ ciclodextrina, trealose e isomaltose foram pouco hidrolisados, e nenhuma atividade enzimática foi detectada na presença de sacarose e $\alpha$-ciclodextrina. O substrato sintético $\alpha$-PNPG foi hidrolisado tanto pela $\alpha$-glucosidase I quanto pela $\alpha$-glucosidase II. Essa característica somada a outros fatores peculiares dessas enzimas nos permitiu identificá-las como $\alpha$-glucosidase. 


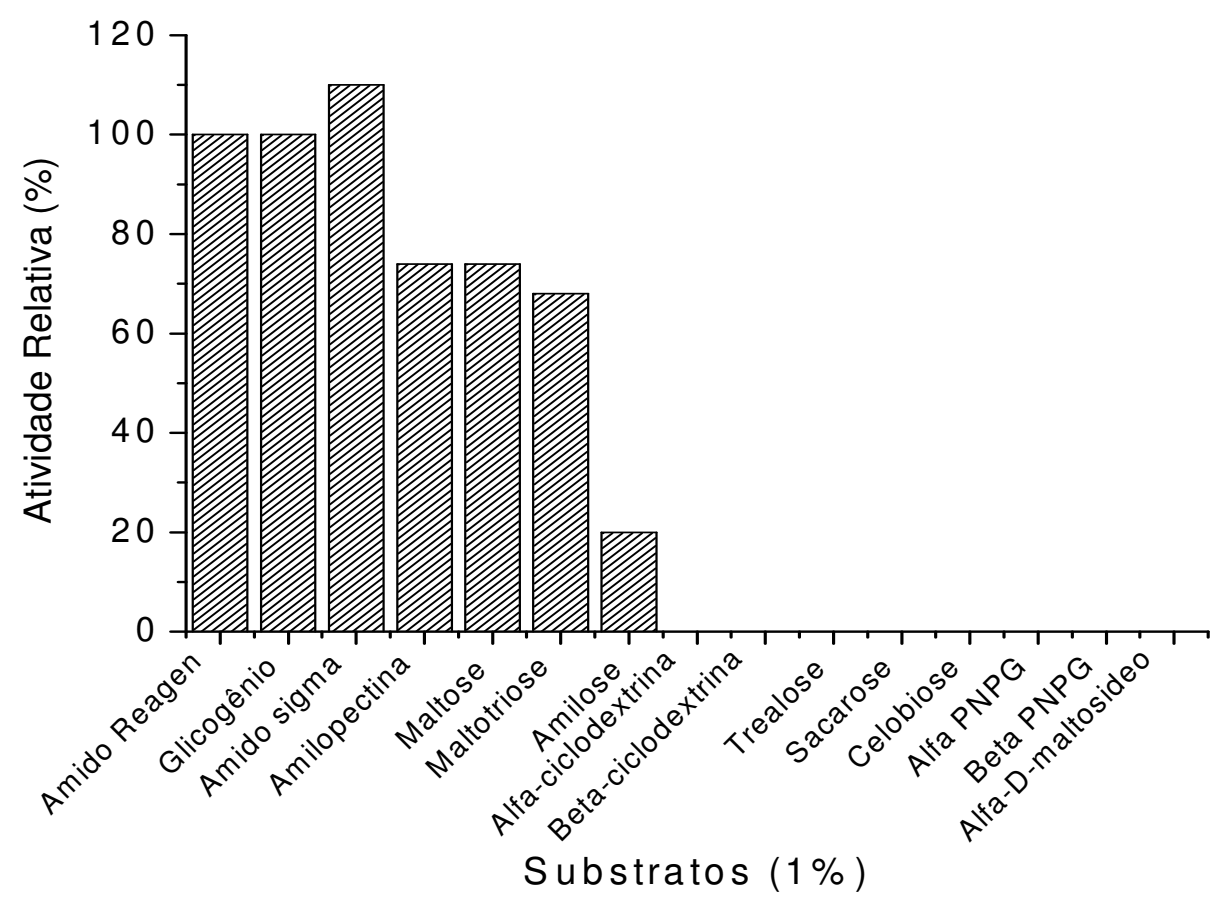

Figura 22: Hidrólise de diferentes substratos pela ação da glucoamilase purificada de A. niveus.

Tabela 18: Hidrólise de diferentes substratos pela ação da $\alpha$-glucosidase I e $\alpha$ glucosidase II de $A$. niveus

Substrato

Amido solúvel

Amilose

Amilopectina

Glicogênio

Maltooligossacarídeo (G10)

Maltopentaose

Maltotetraose

Maltotriose

Isomaltose

Maltose

$\alpha-P N P G$

$\rho$-nitrofenil- $\beta$-pentaosideo

$\alpha$-ciclodextrina

B-ciclodextrina

Trealose

Sacarose $\alpha$-glucosidase I

(\%)

100

82

84

110

23

108

80

106

4,5

69

$+$

0

0

0

0

0

\section{$\alpha$-glucosidase II}

(\%)

100

90

85

115

100

120

92

83

9

65

$+$

0

0

14

0

0

(+) presença de atividade enzimática $(0,12$ e $0,9 \mu \mathrm{mols} / \mathrm{mL}$ para $\alpha$-glucosidase I e II), respectivamente. 


\subsection{3- Cromatografia em camada delgada de sílica (TLC) dos produtos de hidrólise do} amido

Para uma avaliação de quais produtos estariam sendo liberados durante a reação das enzimas purificadas com amido solúvel, foram realizadas cromatografias em camada delgada (TLC). Glicose, maltose, maltotriose, maltotetraose e maltopentaose foram usados como padrões (Figura 23).

Como resultado observou-se que apenas glicose foi liberada como produto de hidrólise do amido pela ação da glucoamilase após duas horas de reação (Figura 23A). Este resultado reforça a hipótese de que a enzima em questão é uma glucoamilase, tendo em vista que o produto formado (glicose) a partir do amido caracteriza a ação dessa enzima. Os produtos liberados pela ação da $\alpha$-glucosidase I sobre o amido solúvel foram glicose, maltose e maltotriose em todos os tempos testados, conforme mostra a Figura 23B. Glicose foi o único produto formado pela ação da $\alpha$-glucosidase II sobre o amido solúvel em todos os tempos analisados (Figura 23C). 

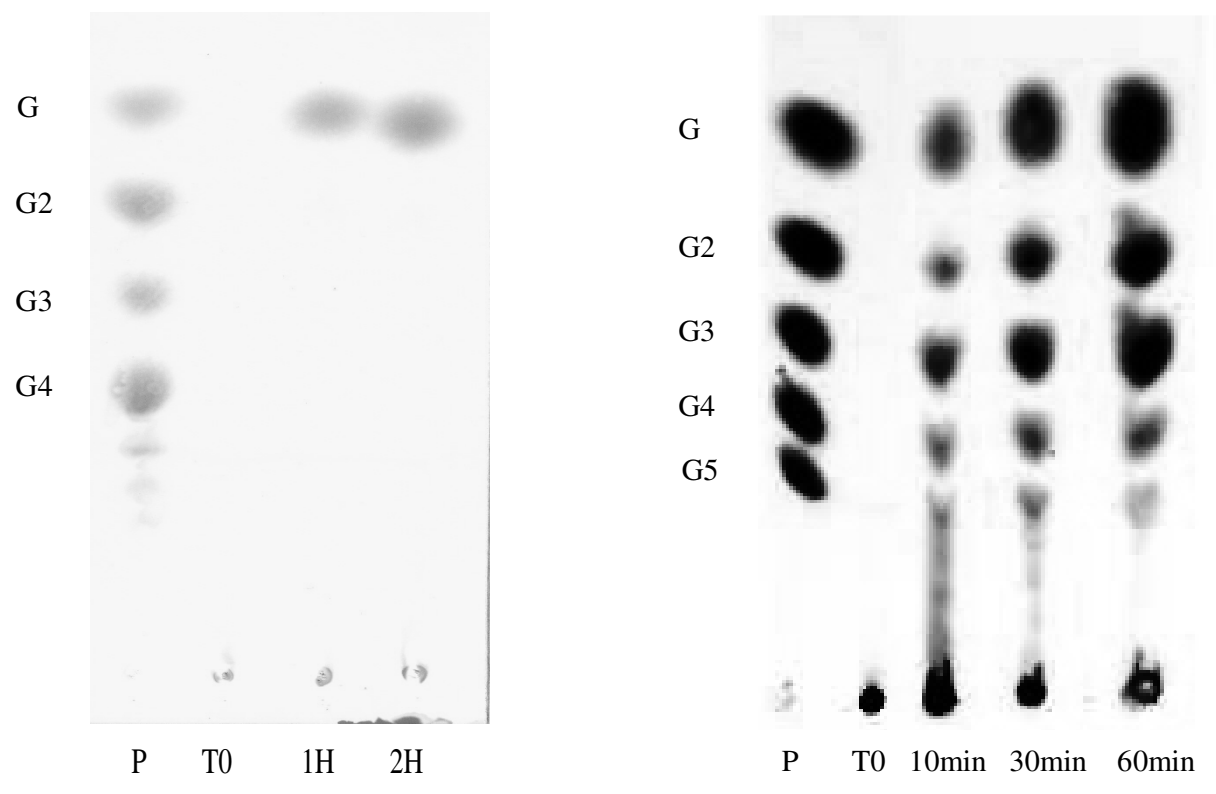

(A)

(B)

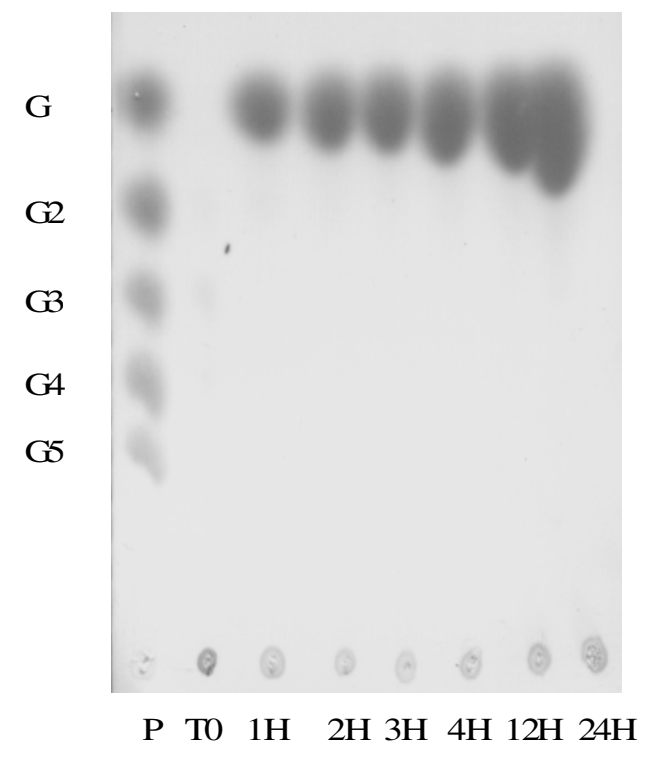

(C)

Figura 23: Análise dos produtos de hidrólise do amido em Cromatografia de Camada Delgada (TLC). (A) glucoamilase, (B) $\alpha$-glucosidase I e (C) $\alpha$-glucosidase II. P- padrão, T0- controle, H- horas de reação, min- minutos de reação. G- glicose, G2- maltose, G3- maltotriose, G4- maltotetraose e G5maltopentaose. 


\subsection{4- Efeito sinergístico das amilases purificadas de $A$. niveus sobre o amido solúvel $5 \%$}

O objetivo desta etapa do trabalho foi avaliar o efeito sinergístico das enzimas amilolíticas sobre o amido solúvel 5\%. Neste experimento as enzimas foram aplicadas junto ao amido sob diferentes combinações. Os produtos de hidrólise foram analisados em HPLC, e as áreas obtidas nos cromatogramas foram comparadas com aquelas obtidas com os padrões. Os resultados são mostrados na Figura 24 e Tabela 19. Após 24 horas de hidrólise, glicose foi o único produto formado quando utilizou-se isoladamente glucoamilase e $\alpha$-glucosidase II, e também o único produto identificado quando se utilizou a mistura das três enzimas. Glicose, maltose e maltotriose foram os produtos de hidrólise formados pela ação da $\alpha$-glucosidase I quando aplicada isoladamente.

Após identificação dos produtos de hidrólises, uma análise de eficiência catalítica foi feita por meio de comparações entre as áreas definidas nos cromatogramas e seus respectivos padrões. A somatória da quantidade de produtos formados por cada enzima, atuando separadamente foi $62 \%$ menor que o produto formado sob ação conjunta das 3 enzimas. A análise mostrou também que a glucoamilase e a $\alpha$-glucosidase II na presença da $\alpha$-glucosidase I foram mais eficientes em 32 e 34\%, respectivamente. A mistura de glucoamilase com $\alpha$ glucosidase II não proporcionou uma diferença muito significativa na eficiência do processo, porém um aumento de $18 \%$ foi verificado. 

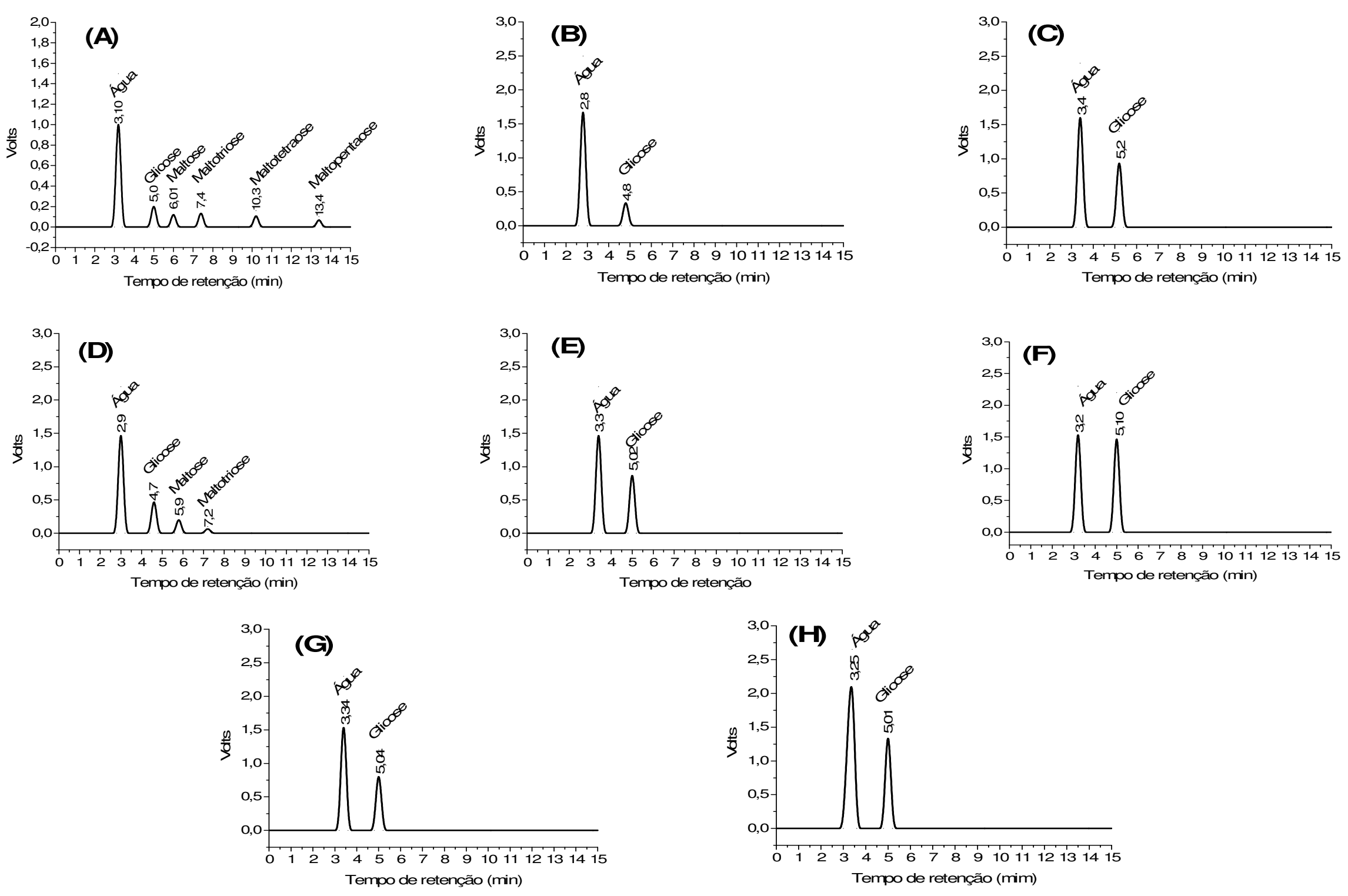

Figura 24: Análise em HPLC dos produtos de hidrólise do amido 5\% pelas enzimas purificadas de A. niveus. (A) padrões, (B) glucoamilase, (C) $\alpha$-glucosidase II, (D) $\alpha$-glucosidase I, (E) $\alpha$-glucosidase I+glucoamilase, (F) $\alpha$-glucosidase I $+\alpha$-glucosidase II, (G) glucoamilase $+\alpha$ glucosidase II e $(\mathrm{H})$ glucoamilase $+\alpha$-glucosidase I $+\alpha$-glucosidase II. 
Tabela 19: Efeito sinergístico das amilases purificadas de $A$. niveus sobre o amido $5 \%$

Enzimas

$\Sigma$ (glucoamilase $+\alpha$-glucosidase II

$+\alpha$-glucosidase I) isoladamente

Glucoamilase $+\alpha$-glucosidase I $+\alpha$-glucosidase II

Glucoamilase $+\alpha$-glucosidase I

$\alpha$-glucosidase $+\alpha$-glucosidase I

Glucoamilase $+\alpha$-glucosidase II

\section{$\%$ produto formado}

\footnotetext{
Glucoamilase $=14 \mathrm{U}$

$\alpha$-glucosidase $\mathrm{I}=5 \mathrm{U}$

$\alpha$-glucosidase II $=16 \mathrm{U}$
}

\subsection{5- Dicroísmo circular}

Dicroísmo circular é por definição, a diferença de absorção da luz circularmente polarizada $(\mathrm{CPL})$ à esquerda $\left(\mathrm{A}_{\mathrm{E}}\right)$ e à direita $\left(\mathrm{A}_{\mathrm{D}}\right)$. A técnica de $\mathrm{CD}$ detecta exatamente $\mathrm{a}$ alteração através desta medida de diferença, após a luz passar pela amostra. Assim, a espectrometria de Dicroísmo circular permite determinar empiricamente a estrutura protéica e sua conformação através da indução de CD ao esqueleto de amida entre 250 e 180nm (o UV distante, ou região peptídica do espectro). O sinal de CD é observado em comprimento de onda, onde a amostra absorve radiação, e o sinal pode ser positivo ou negativo de acordo com a quiralidade da molécula na amostra (D ou L) e da transição estudada. Em princípio, o espectro de CD de uma proteína na sua forma nativa de conformação é a soma das porcentagens apropriadas de cada componentes do espectro (MICHAEL, 1999).

As moléculas protéicas apresentam uma estrutura primária que se refere à seqüência linear de aminoácidos ligados por suas ligações peptídicas. Esta pode ser 
dobrada em diversas formas, sendo que as estruturas secundárias e terciárias finais são determinantes da função da proteína. A metodologia de Dicroísmo Circular é muito utilizada para avaliar a estrutura secundária de macromoléculas biológicas. Com esta técnica é possível detectar mudanças conformacionais na molécula e avaliar as interações com moléculas menores, especialmente àquelas quirais.

Espectros de Dicroísmo Circular foram feitos para as amilases de A. niveus, permitindo a caracterização dos componentes estruturais secundários dessas proteínas através da indução de CD. Os espectros obtidos para as enzimas purificadas, em estudo foram comparados com um espectro de CD de uma proteína padrão com estrutura secundária definida (Figura 25A). Assim, o perfil obtido para as três enzimas (Figura 25B, C e D) mostrou-se característico de proteínas ricas em $\alpha$-hélices. 


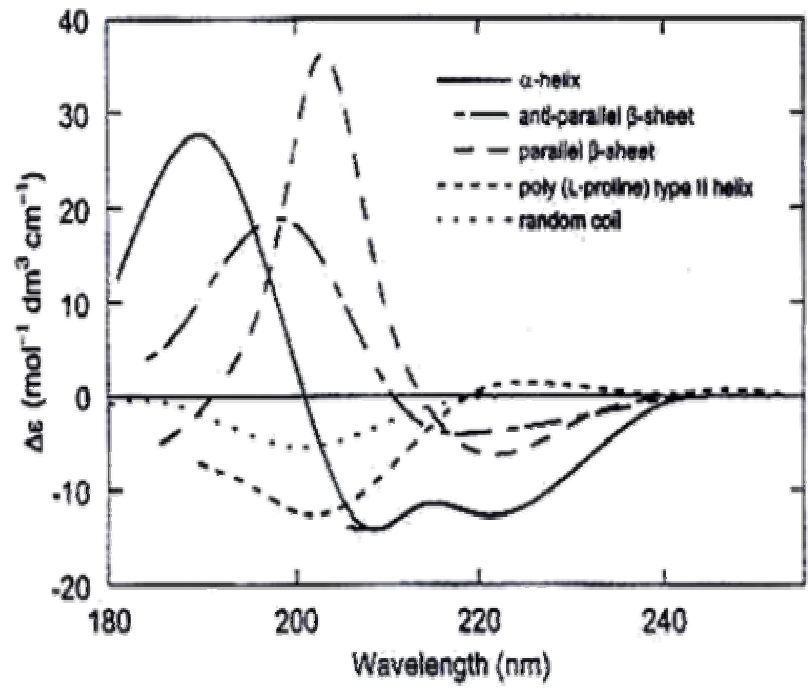

(A)

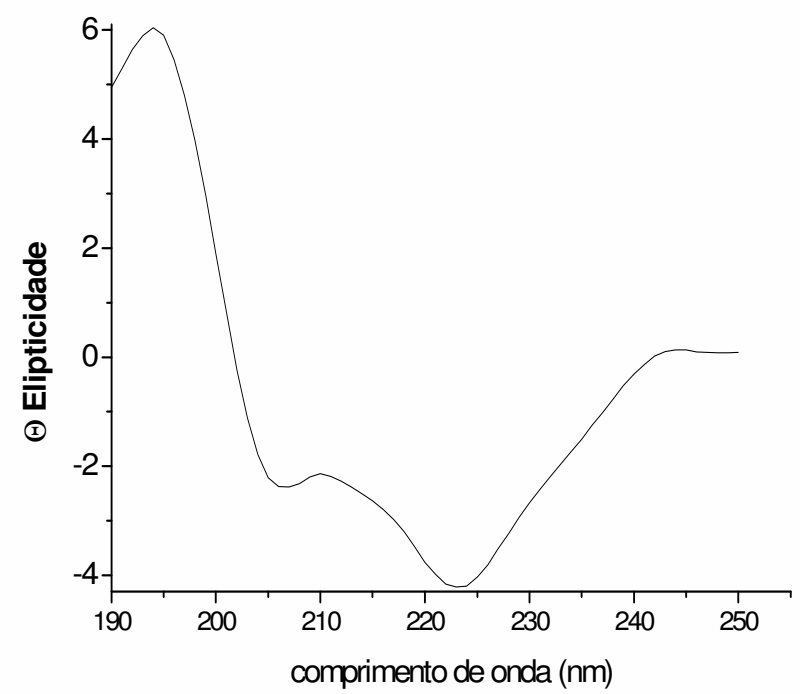

(C)

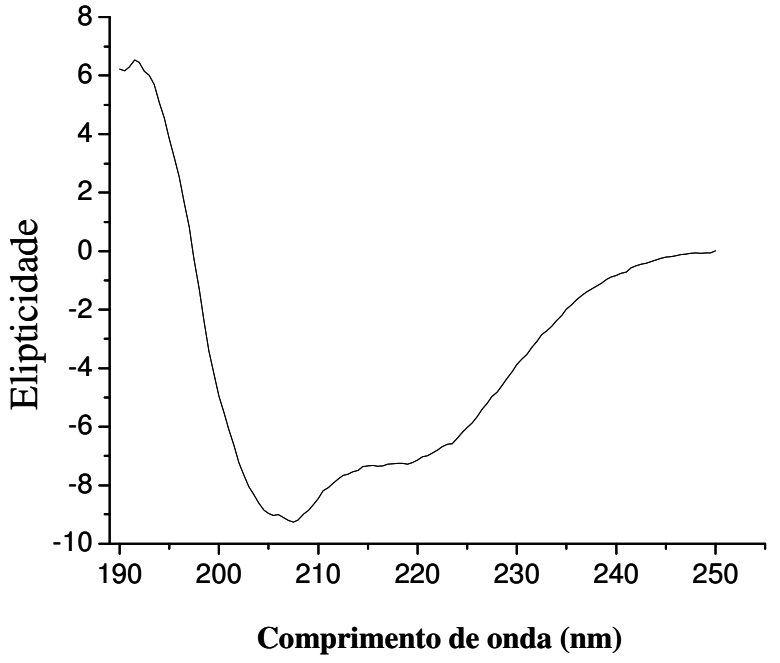

(B)

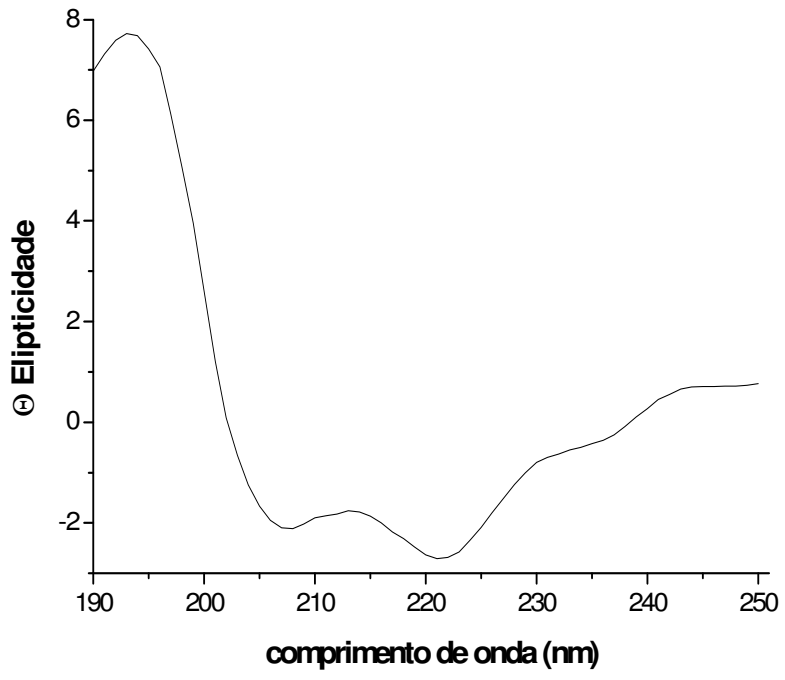

(D)

Figura 25: Dicroísmo circular. (A) Espectro em CD de estrutura secundárias conhecidas, (B) glucoamilase, (C) $\alpha$-glucosidase I e (D) $\alpha$-glucosidase II. 


\subsection{6- Determinação das constantes cinéticas}

A afinidade das amilases puras pelo substrato foi analisada através do procedimento gráfico proposto HANES (1932), utilizando-se o programa Enzyplot (LEONE et al., 1995). O $\mathrm{Km}$ da glucoamilase utilizando amido solúvel como substrato foi de $0,32 \mathrm{mg} / \mathrm{mL}$ e o $\mathrm{V}_{\text {máx }}$ foi de $237 \mathrm{U} / \mathrm{mg}$. A $\alpha$-glucosidase I apresentou um Km de 0,06 mg/mL e um Vmax de 161,3 U/mg com o amido solúvel. Utilizando glicogênio a $\alpha$-glucosidase I apresentou um Km de $0,04 \mathrm{mg} / \mathrm{mL}$ e um Vmax de $190 \mathrm{U} / \mathrm{mg}$. Com a maltose a afinidade da enzima foi menor apresentando um $\mathrm{Km}$ de 0,24 mg/mL e um Vmax de 33,4 U/mg. As constantes cinéticas da $\alpha$ glucosidase II foram determinadas utilizando amido solúvel, maltose, amilopectina, glicogênio e $\alpha$-PNPG. O Km e Vmax obtidos com amido solúvel como substrato foi de 0,07 mg/mL e 310,1 U/mg, respectivamente. Utilizando maltose o $\mathrm{Km}$ e Vmax foram de 0,57 mg/mL e 207,7 U/mg. O Km da $\alpha$-glucosidase II utilizando amilopectina e glicogênio foi de $0,11 \mathrm{mg} / \mathrm{mL}$ e 0,04 U/mg, respectivamente, e os respectivos valores de Vmax foram determinados em 324,6 e 308,3 U/mg. Utilizando o substrato sintético $\alpha$-PNPG a $\alpha$-glucosidase II apresentou um Km de $0,55 \mu \mathrm{mol} / \mathrm{mL}$ e um Vmax de 8,84 U/mg (Tabela 20).

Tabela 20: Constantes cinéticas das amilases purificadas de $A$. niveus.

\begin{tabular}{|c|c|c|c|c|c|}
\hline Enzima & Substrato & Km & Vmax & Kcat & Kcat/Km \\
\hline Glucoamilase & Amido & 0,32 & 237 & 14,2 & 44,4 \\
\hline \multirow[t]{3}{*}{$\alpha$-glucosidase I } & Amido & 0,06 & 161,3 & 17,46 & 12,93 \\
\hline & Glicogênio & 0,04 & 190 & 11,4 & 285 \\
\hline & Maltose & 0,24 & 33,4 & 2,01 & 8,37 \\
\hline \multirow[t]{5}{*}{$\alpha$-glucosidase II } & Amido & 0,07 & 310,1 & 24.62 & 351.71 \\
\hline & Maltose & 0,57 & 207,7 & 13.66 & 23.96 \\
\hline & Amilopectina & 0,11 & 324,6 & 25.48 & 231.64 \\
\hline & Glicogênio & 0,04 & 308,3 & 24.50 & 612.50 \\
\hline & $\alpha$-PNPG & 0,55 & 8,84 & 0.53 & 0.96 \\
\hline
\end{tabular}




\subsection{7- Sequenciamento da glucoamilase}

Através da seqüência de aminoácidos trípticos obtidos para a glucoamilase de A. niveus (SPRAL), foi realizada análise comparativa com glucoamilases de outras espécies do gênero Aspergillus (Tabela 21), revelando similaridade com glucoamilases de Aspergillus niger, A. kawachi, A. ficcum, A. terreus, A. awamori e A. shirousami.

Tabela 21: Análise de sequenciamento da glucoamilase de A. niveus e comparação com outras glucoamilases de outras espécies de Aspergillus.

\begin{tabular}{lcc}
\hline Fungos & Sequencia e posição & Homologia \% \\
\hline A. terreus & SPRAL (299-303) & 100 \\
A. niger & SPRAL (295-299) & 100 \\
A. ficcum & SPRAL (295-299) & 100 \\
A. awamori & SPRAL (294-298) & 100 \\
A. kawachi & SPRAL (294-298) & 100 \\
A. shirousami & SPRAL (294-298) & 100 \\
\hline
\end{tabular}




\subsection{8- Sequenciamento de peptídeos da $\alpha$-glucosidase I e $\alpha$-glucosidase II}

As $\alpha$-glucosidases foram submetidas à análise por SDS-PAGE, seguida de digestão “in situ” por tripsina e os peptídeos trípticos foram analisados por espectrometria de massa. $\mathrm{O}$ "Peptide mass fingerprint" mostrou uma série de peptídeos ionizados protonados e não protonados. Tais peptídeos ionizados foram submetidos a CID-MS/MS (Figura 26), e posteriormente a seqüência parcial foi deduzida (Tabela 22 para $\alpha$-glucosidase I e tabela 23 para $\alpha$-glucosidase II). O "Peptide mass fingerprint" de peptídeos trípiticos e os fragmentos ionizados por CID foram usados para pesquisa em bancos de dados usando o programa Protein Prospector MS-Fit e MS-Tag (http://prospector.ucsf.edu/). A pesquisa no banco de dados encontrou significante similaridade das enzimas de A.niveus com glucan 1,4-alpha-glucosidase de Aspergillus fumigatus. 


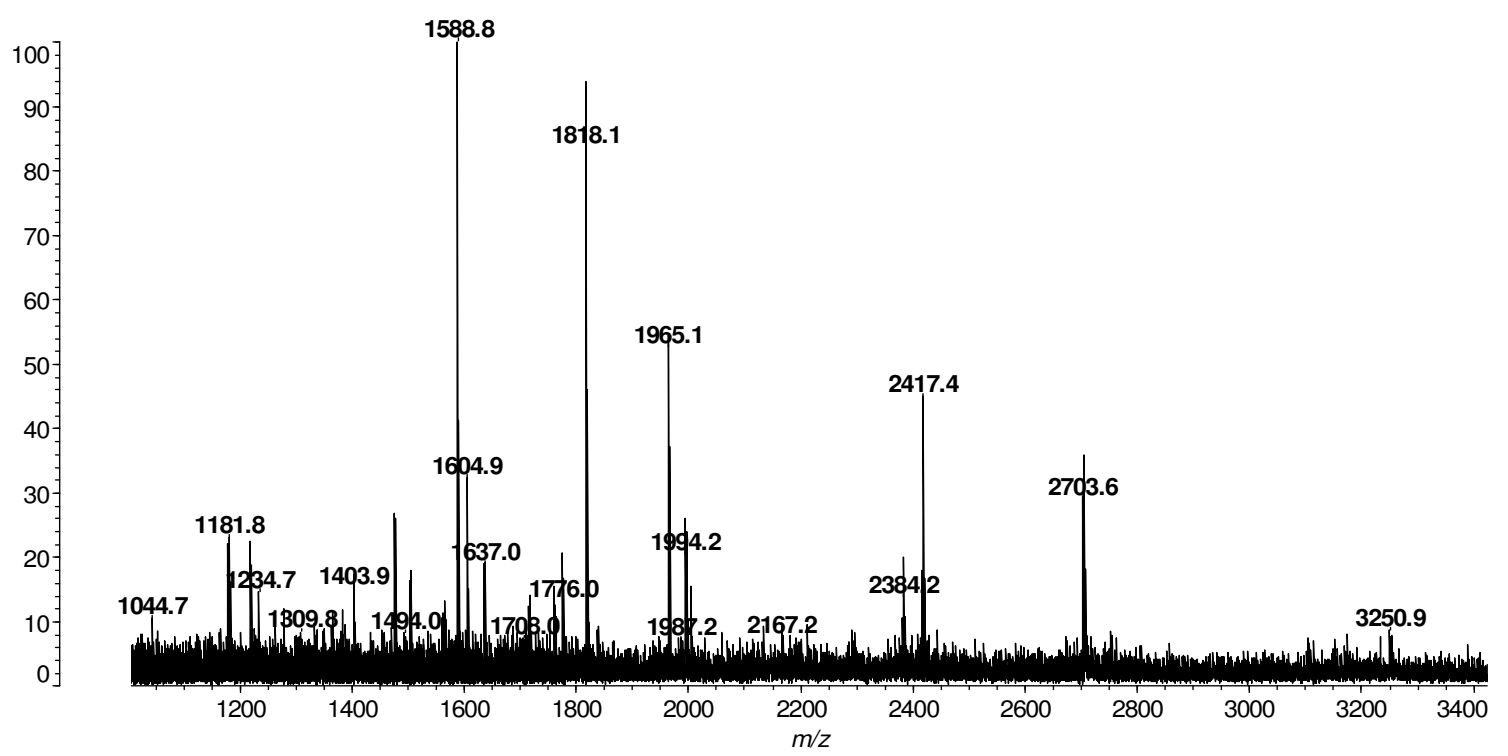

(A)

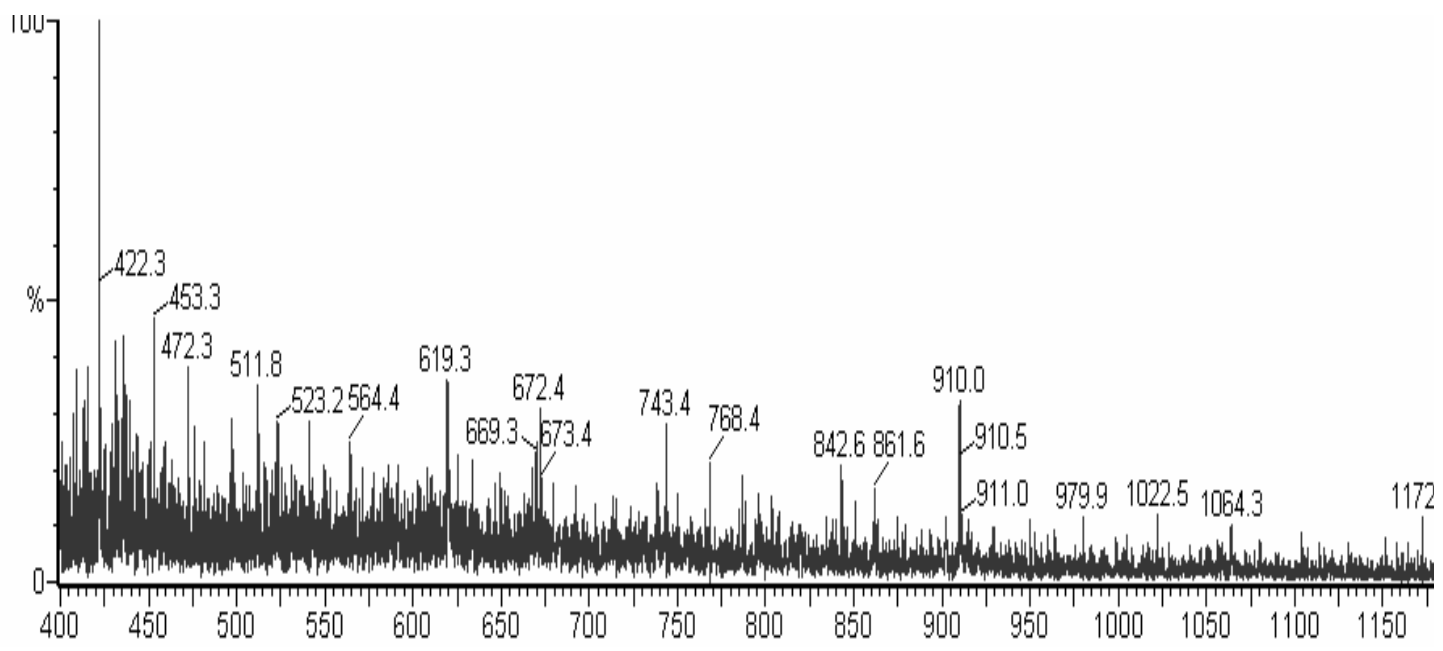

(B)

Figura 26: Mapa dos peptídeos trípticos obtidos da $\alpha$-glucosidase I (A) e $\alpha$-glucosidase II (B). A digestão por tripsina das bandas foram analisadas por CID-MS/MS. As sequiências de aminoácidos de cada peptídeo protonado foram deduzidas por fragmentação dos íons. 
Tabela 22: Colisão induzida por dissociação em electrospray, através de espectrometria de massa de peptídeos trípticos obtidos da banda de $\alpha$-glucosidase $I$.

\begin{tabular}{lll}
\hline$m / z$ & Delta & Sequencia deduzida \\
\hline $1588,7\left[\mathrm{M}+2 \mathrm{H}^{+}\right]$ & 0,1534 & KYNVDMTAFTGAWGRP \\
$1817,95\left[\mathrm{M}+2 \mathrm{H}^{+}\right]$ & 0,0677 & R SVYAINSGIPQGAAVSAGRY \\
$2417,7\left[\mathrm{M}+2 \mathrm{H}^{+}\right]$ & 0,1314 & KPGIIIASPSTSEPDYYYTWTRD \\
& & \\
\hline
\end{tabular}

Tabela 23: Colisão induzida por dissociação em electrospray, através de espectrometria de massa de peptídeos trípticos obtidos da banda de $\alpha$-glucosidase II.

\begin{tabular}{lll}
\hline$m / z$ & Delta & Sequencia deduzida \\
\hline $511,8\left[\mathrm{M}+2 \mathrm{H}^{+}\right]$ & 0,0489 & RALVEGSTFAKR \\
$787,5\left[\mathrm{M}+2 \mathrm{H}^{+}\right]$ & 0,1326 & KIGSISITSTSLAFFKD \\
$910,0\left[\mathrm{M}+2 \mathrm{H}^{+}\right]$ & 0,0501 & RSVYAINSGIPQGAAVSAGRY \\
\hline
\end{tabular}




\subsection{9- Efeito de $\mathrm{N}$-glicanas nas propriedades bioquímicas de glucoamilase e $\alpha$-glucosidase} II

\subsection{1- Cultivo com tunicamicina e purificação das amilases}

O efeito de tunicamicina na síntese e secreção de enzimas microbianas tem sido estudado nos últimos anos. Para determinar o efeito de $\mathrm{N}$-glicanas sobre as enzimas amilolíticas de A. niveus foi adicionado junto ao meio de cultivo $30 \mu \mathrm{g} / \mathrm{mL}$ tunicamicina. Valores semelhantes do peso seco dos micélios determinados a partir de meios de cultivo com e sem a presença de tunicamicina, nos permite inferir que a droga não interferiu no crescimento do microrganismo (dados não mostrados). Concentrações similares de proteínas extracelulares secretadas pelo microrganismo também corrobora com essa afirmação. Os extratos enzimáticos filtrados e livres de micélio foram submetidos a eluição em colunas cromatográficas de troca iônica (DEAE-Fractogel) e exclusão por peso molecular (Sephacryl S-200), para purificação e posterior comparação bioquímica. Os perfis são mostrados na Figura 27. 

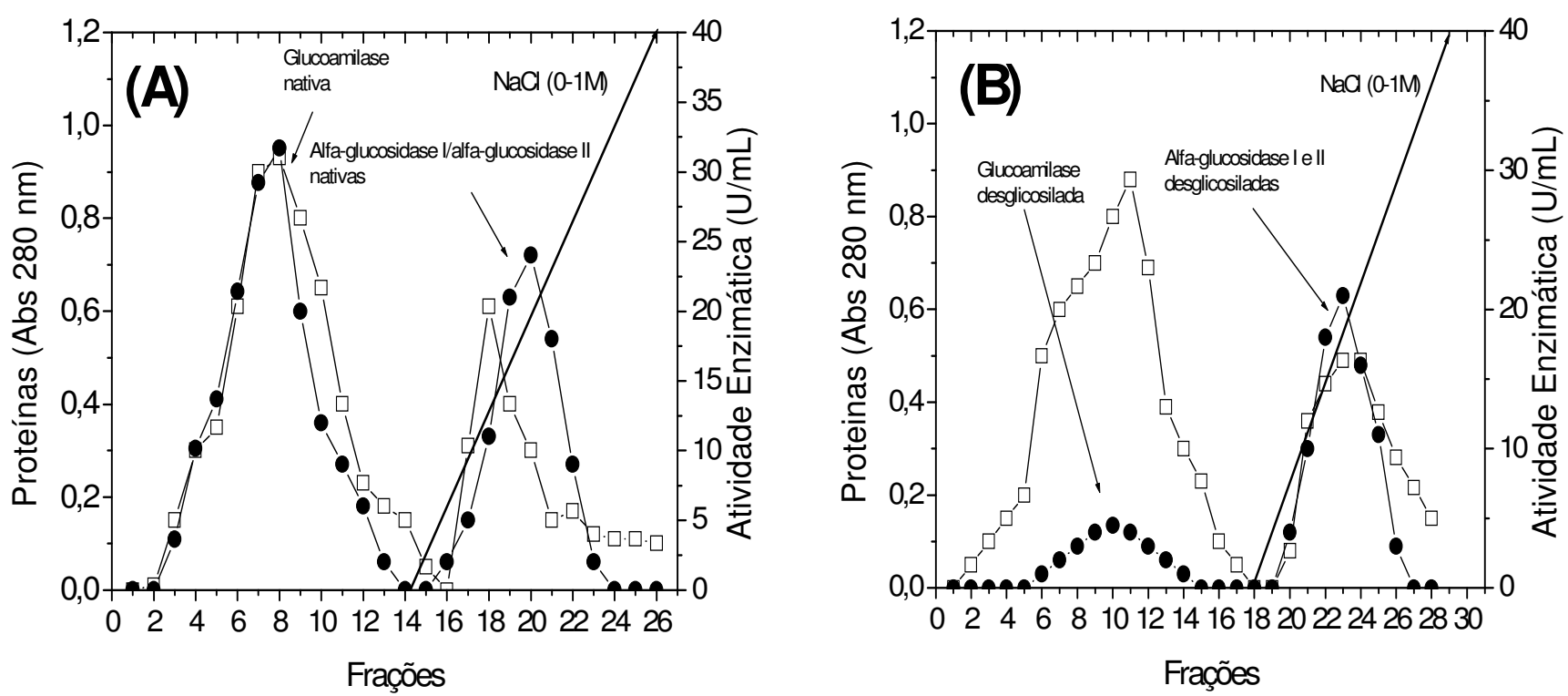

Figura 27: Distribuição de proteínas $(\square)$ e atividade enzimática $(\bullet)$ do extrato enzimático após eluição em cromatografia de troca iônica DEAE-fractogel. (A) extrato enzimático de meio de cultivo sem tunicamicina e (B) extrato enzimático de meio de cultivo com tunicamicina.

Comparando os perfis apresentados para os extratos enzimáticos obtidos com e sem tunicamicina foi possível observar uma grande semelhança em relação as proteínas totais liberadas para o meio extracelular. Quanto a atividade enzimática observa-se uma diminuição significativa nos níveis de atividade da glucoamilase em relação ao extrato enzimático sem tunicamicina, e praticamente nenhuma mudança no perfil para $\alpha$-glucosidases I e II. A presença da atividade enzimática da glucoamilase, embora significativamente menor em meio proveniente de cultivo com tunicamicina nos leva a sugerir que não houve nenhuma interferência do tratamento com tunicamicina na síntese e secreção das enzimas. A menor atividade demonstrada para glucoamilase possivelmente esteja envolvida com reconhecimento 
da enzima pelo substrato, uma vez que glucoamilase desglicosilada foi detectada por análise de SDS-PAGE (Figura 29 A).

A etapa seguinte consistiu em reunir as frações com atividade amilolítica, liofilizar e aplicar em cromatografia por exclusão de massa molecular Sephacryl-S200 conforme mostra a Figura 28 e Tabelas 24, 25, 26 e 27. Da mesma forma como ocorrido na troca iônica, os perfis foram semelhantes e a baixa atividade de glucoamilase tratada com tunicamicina também foi evidenciada. Dentre as $\alpha$-glucosidases I e II, observou-se uma diferença com relação a atividade enzimática onde uma baixa atividade da $\alpha$-glucosidase I foi determinada. Assim como ocorrido com a glucoamilase, parece haver uma relação entre o tratamento com tunicamicina e o reconhecimento pelo substrato. Situação oposta ocorre com a $\alpha$-glucosidase II, onde não foram observadas diferenças entre as enzimas tratadas e não tratadas com tunicamicina. As frações contendo atividade enzimática foram tomadas em um "pool', liofilizadas e aplicadas em SDS-PAGE para análise de homogeneidade (Figura 29). 

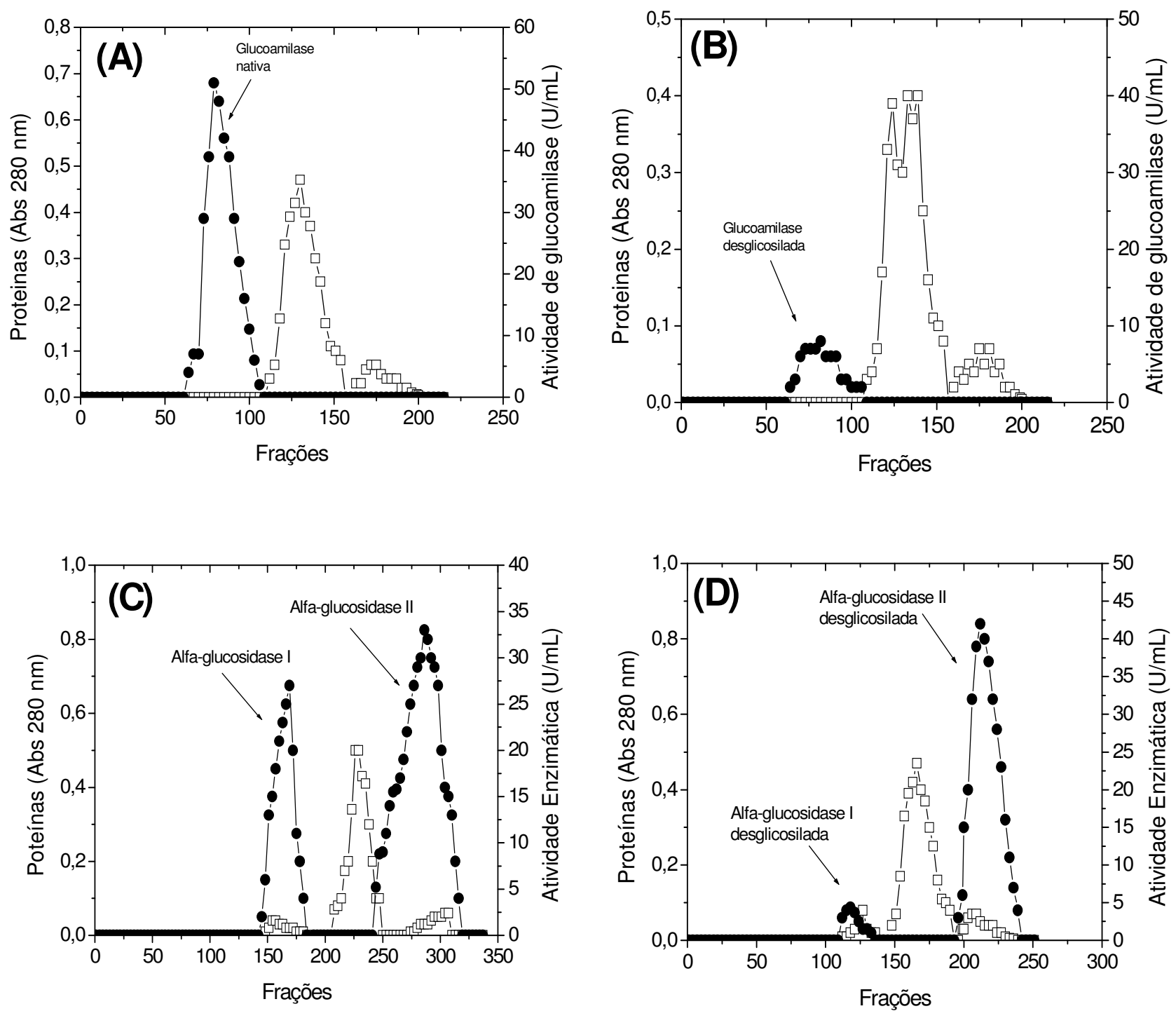

Figura 28: Distribuição de proteínas $(\square)$ e atividade enzimática $(\bullet)$ após eluição em cromatografia de exclusão por massa molecular Sephacryl-S200 (A) glucoamilase proveniente de meio sem tunicamicina, (B) glucoamilase proveniente de meio com tunicamicina, (C) $\alpha$-glucosidases I e II proveniente de meio sem tunicamicina e (D) $\alpha$-glucosidases I e II proveniente de meio com tunicamicina. 
Tabela 24: Purificação da glucoamilase produzida por $A$. niveus em meio sem tunicamicina.

\begin{tabular}{ccccccc}
\hline \hline Procedimentos & $\begin{array}{c}\text { Volume } \\
\text { total } \\
(\mathbf{m L})\end{array}$ & $\begin{array}{c}\text { Proteínas } \\
\text { (mg total) }\end{array}$ & $\begin{array}{c}\text { Atividade } \\
\text { amilolítica } \\
\text { total }\end{array}$ & $\begin{array}{c}\text { Atividade } \\
\text { Específica } \\
\text { (U/mg proteína) }\end{array}$ & $\begin{array}{c}\text { Recuperação } \\
(\%)\end{array}$ & $\begin{array}{c}\text { Fator de } \\
\text { purificação }\end{array}$ \\
Extrato Bruto & 100,0 & 16,7 & 3100 & 185,6 & 100,0 & 1,0 \\
DEAE- & 85 & 7 & 2300 & 328,6 & 74 & 1,77 \\
$\begin{array}{c}\text { Fractogel } \\
\text { Sephacryl- S200 }\end{array}$ & 22 & 3,6 & 1416 & 393,3 & 45,7 & 2,20 \\
\hline \hline
\end{tabular}

Tabela 25: Purificação da glucoamilase produzida por A. niveus em meio com tunicamicina.

\begin{tabular}{ccccccc}
\hline \hline Procedimentos & $\begin{array}{c}\text { Volume } \\
\text { total } \\
(\mathbf{m L})\end{array}$ & $\begin{array}{c}\text { Proteínas } \\
\text { (mg total) }\end{array}$ & $\begin{array}{c}\text { Atividade } \\
\text { amilolítica } \\
\text { total }\end{array}$ & $\begin{array}{c}\text { Atividade } \\
\text { Específica } \\
\text { (U/mg } \\
\text { proteína) }\end{array}$ & $\begin{array}{c}\text { Recuperação } \\
(\%)\end{array}$ & $\begin{array}{c}\text { Fator de } \\
\text { purificação }\end{array}$ \\
Extrato Bruto & 100,0 & 14,6 & 60 & 4,11 & 100,0 & 1,0 \\
DEAE- & 90 & 7,2 & 42 & 5,83 & 70 & 1,42 \\
$\begin{array}{c}\text { Fractogel } \\
\text { Sephacryl- S200 }\end{array}$ & 25 & 2,9 & 26 & 8,96 & 43 & 2,18 \\
\hline \hline
\end{tabular}


Tabela 26: Purificação de $\alpha$-glucosidase I e $\alpha$-glucosidase II de A. niveus provenientes de meio de cultivo sem tunicamicina.

\begin{tabular}{|c|c|c|c|c|c|c|}
\hline Procedimentos & $\begin{array}{c}\text { Volume } \\
\text { total } \\
(\mathrm{mL})\end{array}$ & $\begin{array}{l}\text { Proteínas } \\
\text { (mg total) }\end{array}$ & $\begin{array}{c}\text { Atividade } \\
\text { amilolítica } \\
\text { total }\end{array}$ & $\begin{array}{c}\text { Atividade } \\
\text { Específica } \\
\text { (U/mg } \\
\text { proteína) }\end{array}$ & $\begin{array}{c}\text { Recuperação } \\
(\%)\end{array}$ & $\begin{array}{c}\text { Fator de } \\
\text { purificação }\end{array}$ \\
\hline Extrato bruto & 100 & 16,7 & 3100 & 185,6 & 100,0 & 1,0 \\
\hline $\begin{array}{l}\text { DEAE-Fractogel } \\
\text { (Pico II) }\end{array}$ & 70 & 7 & 760 & 126,1 & 24,5 & 0,7 \\
\hline $\begin{array}{l}\text { Sephacryl S-200 } \\
(\alpha \text {-glucosidase I) }\end{array}$ & 23 & 1,6 & 235 & 146,9 & 7,5 & 0,8 \\
\hline$(\alpha$-glucosidase II) & 40 & 2,2 & 410 & 188,1 & 13 & 1,0 \\
\hline
\end{tabular}

Tabela 27: Purificação de $\alpha$-glucosidase I e $\alpha$-glucosidase II de $A$. niveus provenientes de meio de cultivo com tunicamicina.

\begin{tabular}{lcccccc}
\hline \multicolumn{1}{c}{ Procedimentos } & $\begin{array}{c}\text { Volume } \\
\text { total } \\
(\mathbf{m L})\end{array}$ & $\begin{array}{c}\text { Proteínas } \\
(\mathbf{m g} \text { total) }\end{array}$ & $\begin{array}{c}\text { Atividade } \\
\text { amilolítica } \\
\text { total }\end{array}$ & $\begin{array}{c}\text { Atividade } \\
\text { Específica } \\
\text { (U/mg } \\
\text { proteína) }\end{array}$ & $\begin{array}{c}\text { Recuperação } \\
(\%)\end{array}$ & $\begin{array}{c}\text { Fator de } \\
\text { purificação }\end{array}$ \\
\hline Extrato bruto & 100 & 15 & 1140 & 76 & 100,0 & 1,0 \\
$\begin{array}{l}\text { DEAE-Fractogel } \\
\text { (Pico II) }\end{array}$ & 65 & 5,2 & 425 & 81,7 & 45,2 & 1,0 \\
$\begin{array}{l}\text { Sephacryl S-200 } \\
(\alpha \text {-glucosidase I) }\end{array}$ & 13 & 0,8 & 35 & 186,6 & 3,7 & 2,4 \\
$(\alpha$-glucosidase II) & 24 & 2,0 & 335 & 179,3 & 29 & 2,3 \\
\hline
\end{tabular}




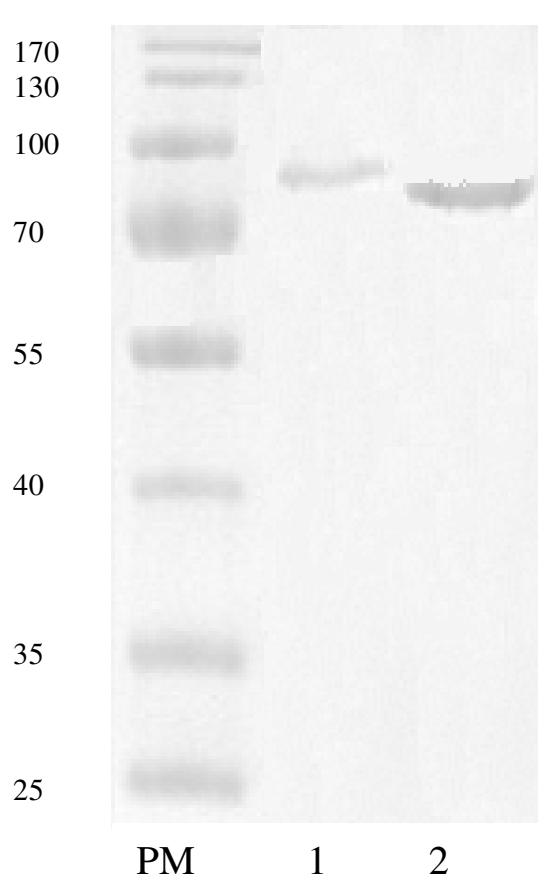

(A)

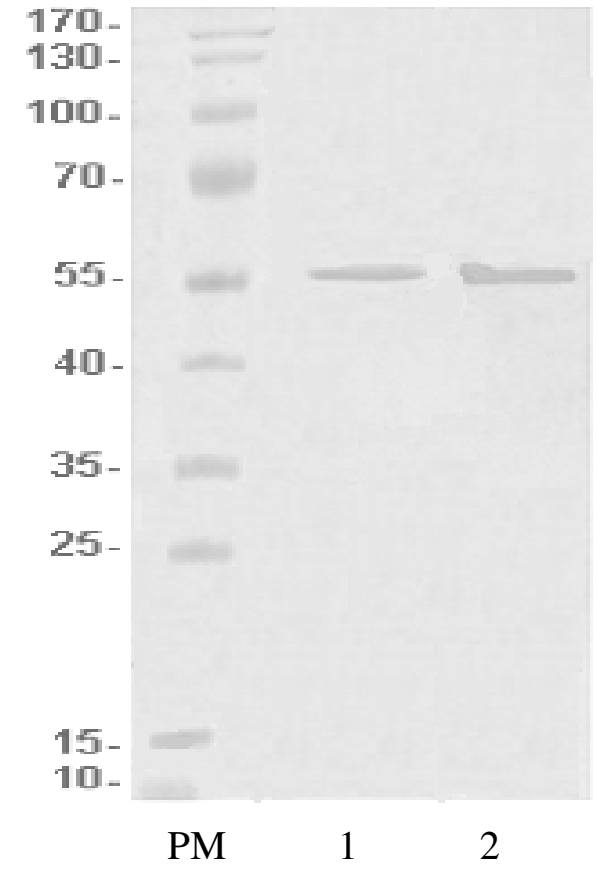

(B)

Figura 29: SDS-PAGE das enzimas purificadas coradas com Comassie Brilhante Blue. (A)glucoamilase e (B)- $\alpha$-glucosidase II. PM: marcador de massa molecular, 1: enzima nativa e 2: enzima desglicosilada.

\subsection{2- Efeito do pH e temperatura na atividade e estabilidade da $\alpha$-glucosidase II}

\section{nativa e deglicosilada}

Ambas as enzimas apresentaram mesmo $\mathrm{pH}$ ótimo de atividade, e a estabilidade ao $\mathrm{pH}$ foi muito semelhante (Figuras $30 \mathrm{C}$ e D). A temperatura ótima para a enzima nativa e deglicosilada foi de $65^{\circ} \mathrm{C}$ (Figura $30 \mathrm{~A}$ ), porém uma diferença em relação a estabilidade à temperatura foi verificada. A $\alpha$-glucosidase II proveniente de meio de cultivo com tunicamicina apresentou estabilidade inferior àquela mostrada para a enzima nativa (Figura 30 B) 

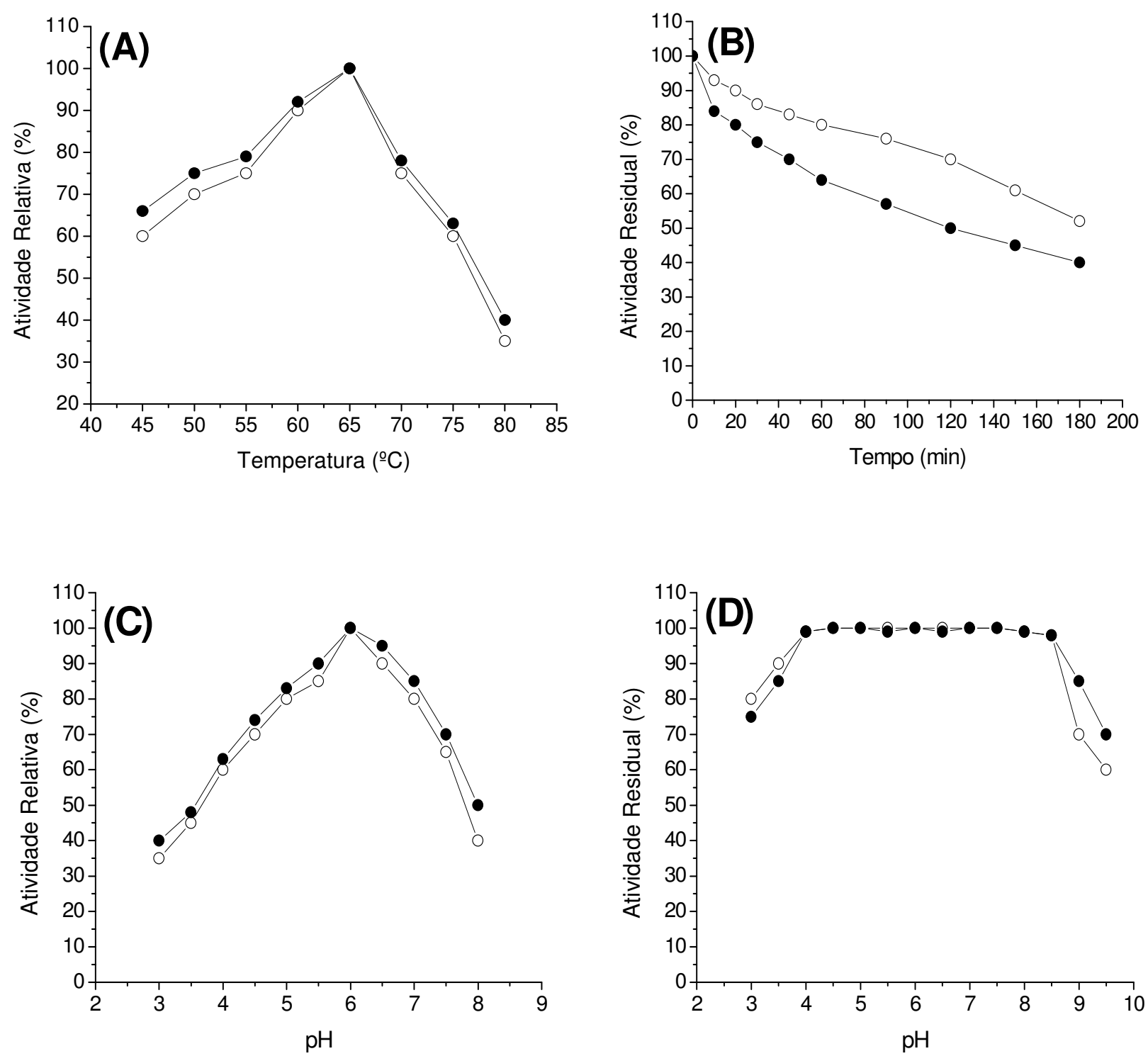

Figura 30: Efeito do $\mathrm{pH}$ e temperatura na atividade e estabilidade da $\alpha$-glucosidase II nativa e desglicosilada. A- temperatura ótima de atividade B- estabilidade a $60^{\circ} \mathrm{C}, \mathbf{C}$ - $\mathrm{pH}$ ótimo e Destabilidade ao $\mathrm{pH}$.

Legenda: -O- enzima nativa e -•- enzima desglicosilada. 


\subsection{3- Constantes cinéticas da $\alpha$-glucosidase II nativa e deglicosilada}

Conforme mostra a Tabela 28, praticamente não houve diferença entre as constantes cinéticas das enzimas nativas e desglicosiladas. Dessa forma podemos inferir que o tratamento com tunicamicina não alterou a especificidade da enzima pelos seus substratos.

Tabela 28: Efeito da tunicamicina no Km e Vmax da $\alpha$-glucosidase II secretada por $A$. niveus.

\begin{tabular}{lcccc}
\hline Substrato & \multicolumn{2}{c}{$\alpha$-glucosidase II nativa } & \multicolumn{2}{c}{$\alpha$-glucosidase II desglicosilada } \\
& Km & Vmax & Km & Vmax \\
\hline Amido & $0.62 \mathrm{mg} / \mathrm{mL}$ & 382.7 & $0.60 \mathrm{mg} / \mathrm{mL}$ & 337.6 \\
Maltose & $0.57 \mathrm{mg} / \mathrm{mL}$ & 344.3 & $0.51 \mathrm{mg} / \mathrm{mL}$ & 316.0 \\
$\alpha-\rho N P G$ & $0.55 \mu \mathrm{mols} / \mathrm{mL}$ & 8.840 & $0.52 \mu \mathrm{mols} / \mathrm{mL}$ & 7.740 \\
\hline
\end{tabular}

\subsection{4- Estudo de afinidade das enzimas glucoamilase e $\alpha$-glucosidase II para $\mathrm{N}$ e}

\section{O-glicosilação}

Os pontos isoelétricos (pI) e as massas moleculares (MW) das proteínas nativas foram calculados utilizando-se o software "Compute pI/Mw" (Tabelas 29 e 32), e os potenciais sítios de $N$-glicosilação (Asn-X-Thr / Ser) foram preditos pelo software "NetNGlyc 1.0 Server" (Tabela 30 e Fig 32A) (GASTEIGER et al., 2005). Em uma série de investigações, $N$ glicosilação tem se mostrado determinante para secreção enzimática, afinidade de ligação e especificidade ao substrato, permitindo que a proteína desenvolva finamente sua atividade catalítica. Na maioria dos casos a eliminação de todos os possíveis sítios de $N$-glicosilação de uma enzima resulta em uma redução significativa dos níveis de secreção, enquanto a remoção pontual destes sítios geralmente resulta na expressão de enzimas com atividade marcadamente reduzida, sendo esta redução proporcional ao número de possíveis sítios de glicosilação. Enzimas totalmente desglicosiladas demonstram atividade mínima quando comparadas a mesma estrutura glicosilada. Por outro lado, recentemente vários casos têm sido descritos onde 
a deglicosilação de uma enzima resulta em um aumento significativo na atividade catalítica, afinidade de ligação e especificidade ao substrato alterada, demonstrando a complexidade do papel que $N$-glicanas desempenham na regulação da função de enzimas (SKROPETA, 2009).

Quando comparada a $N$-glicosilação, a $O$-glicosilação é variável na composição de açúcares e o modo de ligação dos mesmos. Em fungos, proteínas secretadas são geralmente manosiladas por $O$-manosiltransferase no retículo endoplasmático, e subsequentemente glicosiladas por várias glicosiltransferases no aparelho de Golgi para formar glicoproteínas com diversas estruturas de $O$-glicanas. $O$-glicosilação de proteínas tem papel na modulação da função de proteínas secretadas aumentando a estabilidade e solubilidade das mesmas, através da proteção contra degradação de proteases (GOTO, 2007). Os potenciais sítios de $O$ glicosilação foram preditos (Fig 32B.) para $\alpha$-glicosidase e Tabela 32 para glucoamilase utilizando o software "NetOGlyc 3.1 Server" (JULENIUS et al., 2005). Os domínios de ambas enzimas foram preditos por "Simple Modular Architeture Research Tool" (SMART) (LETUNIC et al., 2008) (Tabelas 31 e 32). Foram encontrados 2 domínios preditos para $\alpha$ glicosidase II e vários domínios para glucoamilase. A família 15 das glicosil hidrolases (GH15) compreende enzimas com atividades conhecidas; glucoamilase (EC 3.2.1.3), $\alpha$ glicosidase (EC 3.2.1.20) e glicodextranase (EC 3.2.1.70). O domínio “CBM 20” (Carbohydrate Binding Module) se liga ao amido, e é encontrado frequentemente na região Cterminal de uma variedade de glicosil hidrolases atuando em polissacarídeos com mais eficiência do que em oligossacarídeos.

Para confirmar os dados de bioinformática, como potenciais sítios de $\mathrm{N}$ - e Oglicosilação, analisou-se o comportamento destas proteínas sob colunas de Concanavalina A e Jacalina, respectivamente. Concanavalina A é uma lectina originalmente extraída de sementes de Canavalia ensiformis que liga especificamente à proteínas N-glicosiladas. Jacalina é uma lectina conhecida por sua estabilidade em se ligar a oligossacarídeos O-ligados. Os dados de 
bioinformática foram devidamente confirmados, onde a glucoamilase interagiu fortemente com a Concanavalina (vários possíveis sítios de ligação para $\mathrm{N}$-glicanas) e não demonstrou nenhuma interação com Jacalina (somente 1 provável sítio de ligação para O-glicanas) (Tabela 33), por outro lado, a $\alpha$-glucosidase II não interagiu com Concanavalina A (somente dois sítios potenciais), por outro lado, a mesma se liga a Jacalina, sugerindo que esta proteína contém O-glicanas (Figura 31).

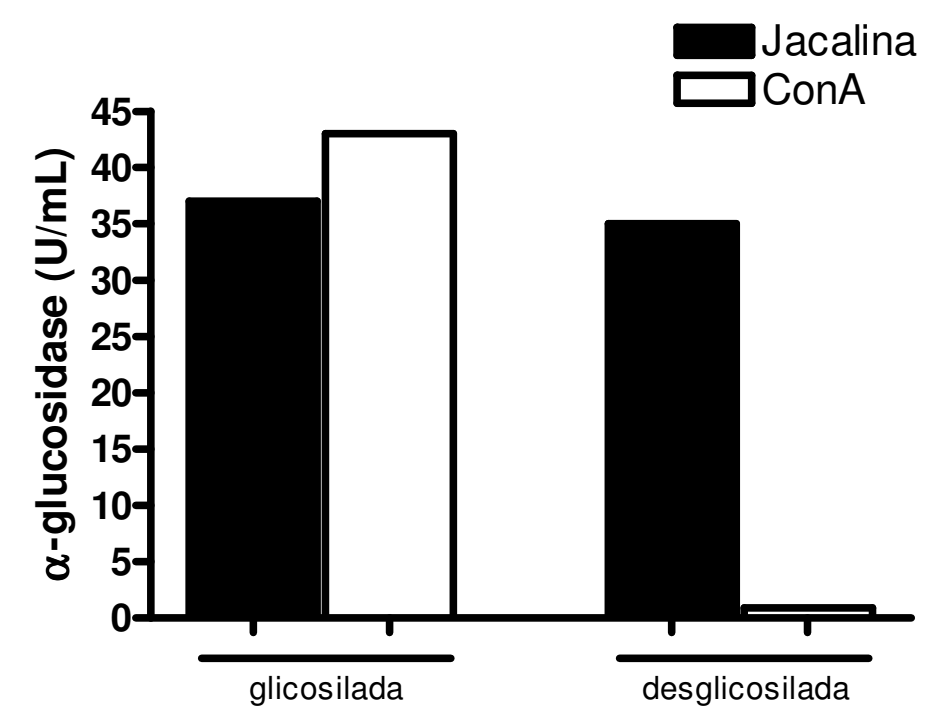

Figura 31: Atividade de $\alpha$-glucosidase II nativa e desglicosilada adsorvidas em Jacalina e Concanavalina A. 
Tabela 29: Parâmetros de glucoamilase e $\alpha$-glucosidase II.

\begin{tabular}{|l|c|c|c|c|c|c|}
\hline \multicolumn{1}{|c|}{ Enzimas } & $\begin{array}{c}\text { Genes } \\
(\mathbf{k b})\end{array}$ & $\begin{array}{c}\text { Proteína } \\
(\mathbf{a a})\end{array}$ & EC & $\begin{array}{c}\text { CAZy } \\
\text { Família }\end{array}$ & $\begin{array}{c}\text { Massa } \\
\text { molecular }\end{array}$ & pI \\
\hline glucoamilase & 1,9 & 704 & 3.2 .1 .3 & GH15 & 77.15 & 5.57 \\
\hline$\alpha-$ & 1.89 & 631 & 3.2 .1 .20 & GH 15 & 67.16 & 5.12 \\
glucosidaseII & & & & & & \\
\hline
\end{tabular}

Tabela 30: Sítios predicados de N-glicosilação para $\alpha$-glucosidase II.

\begin{tabular}{ccc}
\hline Sítios & Posição & Seqüência \\
\hline 1 & 121 & NPSG \\
2 & 422 & NGSL \\
3 & 610 & NRSY \\
4 & 627 & NDTW \\
\hline
\end{tabular}

Tabela 31: Domínios predicados de $\alpha$-glucosidase II.

\begin{tabular}{ccc}
\hline Nome & Inicio & final \\
\hline Pfam: Glyco_hydro_15 & 40 & 454 \\
Pfam: CBM_20 & 529 & 625 \\
\hline
\end{tabular}




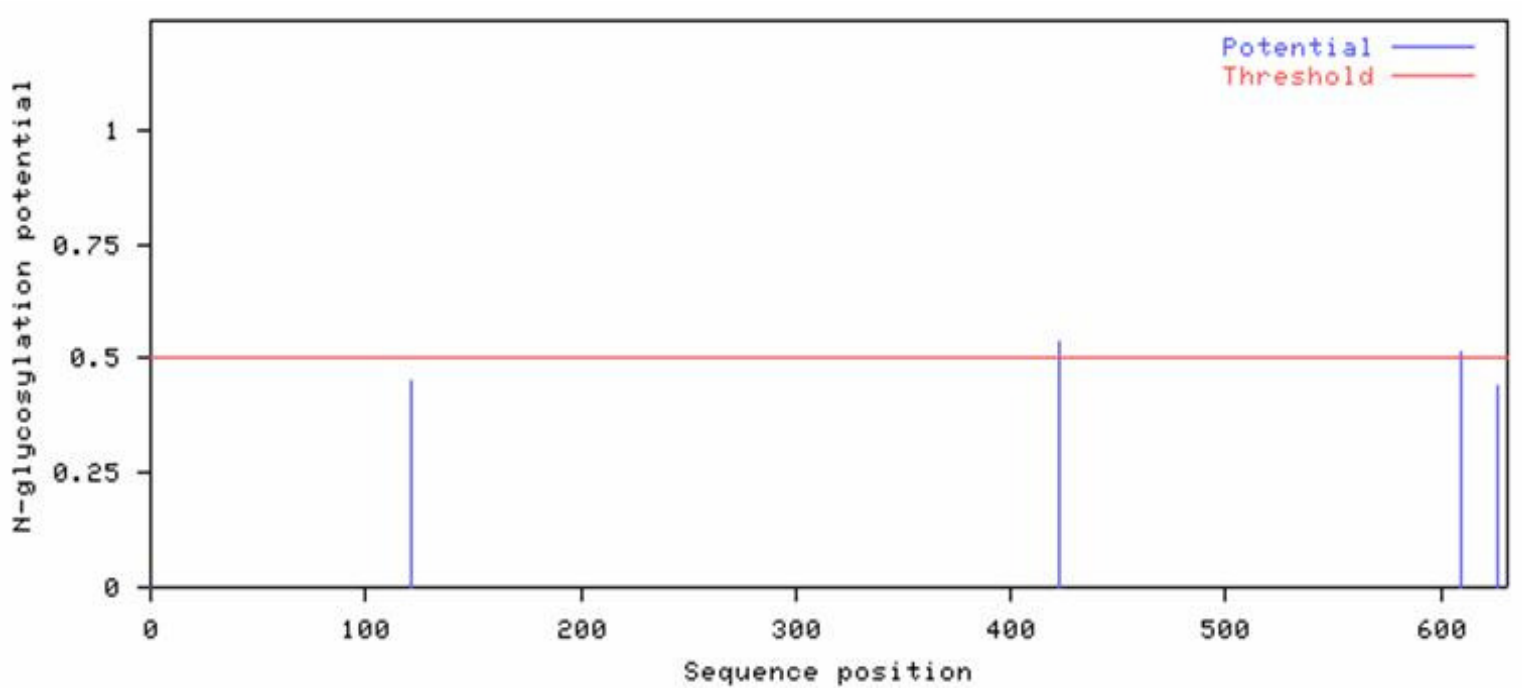

(A)

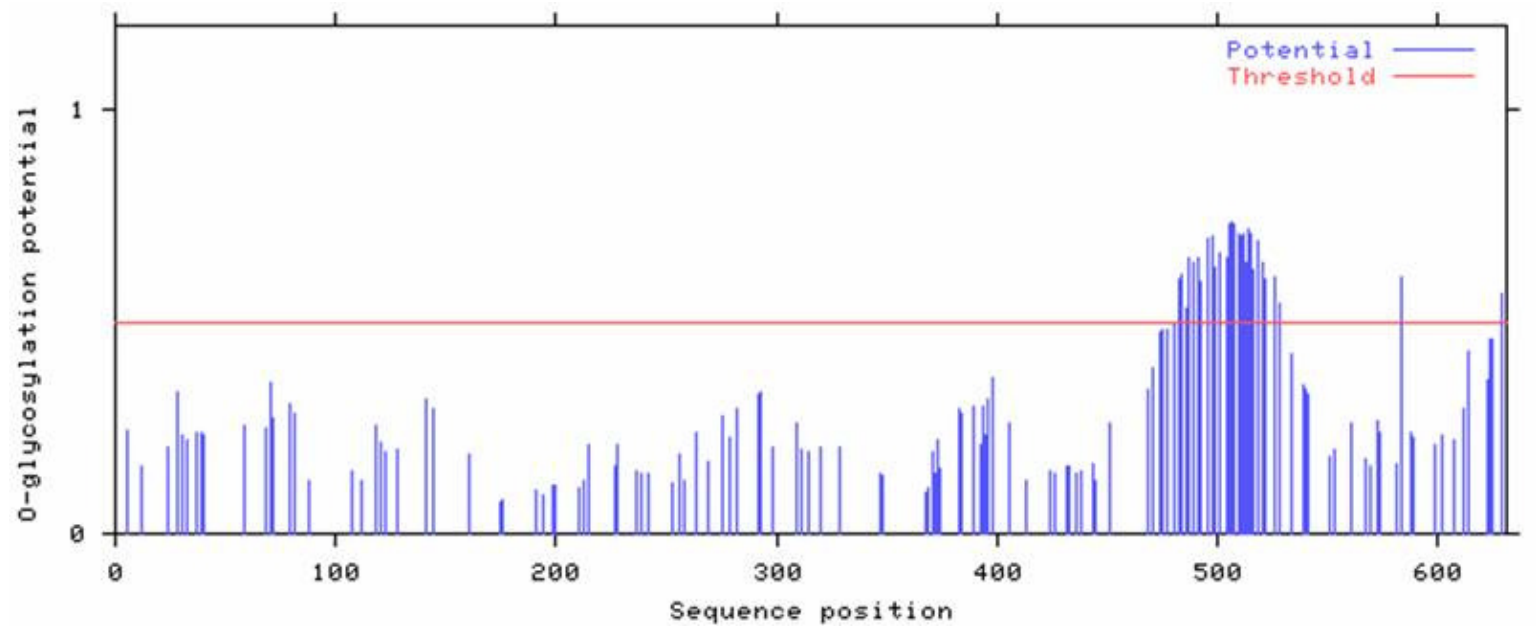

(B)

Figura 32: Potenciais sítios de N- (A) e O-glicosilação (B) para $\alpha$-glucosidase II. 
Tabela 32: Potenciais sítios de N- e O-glicosilação para glucoamilase

\begin{tabular}{|c|c|c|c|c|c|}
\hline Proteína & $\begin{array}{c}\text { Número de } \\
\text { aminoácidos }\end{array}$ & $\begin{array}{c}\text { Massa } \\
\text { molecular } \\
\text { (kDa) }\end{array}$ & pI & $\begin{array}{c}\text { Potenciais } \\
\text { sítios de N- } \\
\text { glicosilação }\end{array}$ & $\begin{array}{c}\text { Potenciais } \\
\text { sítios de O- } \\
\text { glicosilação }\end{array}$ \\
\hline glucoamilase & 704 & 77,15 & 5,52 & 213 (NPSG) & 94 (T) \\
& & & & 286 (NSST) & \\
& & & & 560 (NISL) & \\
& & & 549 (NPSA) & \\
& & & 661 (NATT) & \\
& & & 696 (NATI) & \\
\hline
\end{tabular}

\subsection{0- Imobilização de glucoamilase e $\alpha$-glucosidase II}

Esta etapa do trabalho consistiu em imobilizar a glucoamilase e a $\alpha$-glucosidaseII em diferentes condições, objetivando conseguir derivados mais ativos e estáveis. Para tais procedimentos foram usados suportes como DEAE-Sephacel, Sepharose Q, Glioxil PEI, Glioxil MANAE (trocadores iônicos) e os suportes que estabelecem ligações covalentes com as enzimas tais como, agarose $4 \mathrm{BCL}$ ativada com brometo de cianogênio ( $\mathrm{BrCN})$ e glioxil agarose a $\mathrm{pH} 10,5$.

\subsection{1- Imobilização da glucoamilase}

A glucoamilase de A. niveus foi misturada com Sepharose Q, DEAE-Sephacel, Glioxil MANAE e BrCN na proporção de $1 \mathrm{~g}$ de suporte para cada $10 \mathrm{~mL}$ de enzima em $\mathrm{pH}$ 7,0. A Figura 33 A mostra o perfil de adsorção da enzima com o suporte, também chamada de cinética de imobilização. Observa-se que em 60 minutos de interação com os suportes boa parte das enzimas já estavam imobilizadas. O glioxil MANAE foi o que proporcionou melhor rendimento. 
Depois do preparo dos derivados, os mesmos foram levados a banho a 60C e alíquotas foram retiradas em diferentes tempos para medida da atividade enzimática. A estabilidade térmica foi muito semelhante entre a enzima livre e os derivados Sepharose Q, DEAESephacel e glioxil MANAE, por outro lado o derivado BrCN apresentou uma estabilidade maior em relação a enzima livre (Figura 33 B). Esse resultado já era esperado visto que o BrCN, por estabelecer ligação covalente unipontual com a enzima, torna esse derivado mais estável que aqueles obtidos com suportes trocadores iônicos.

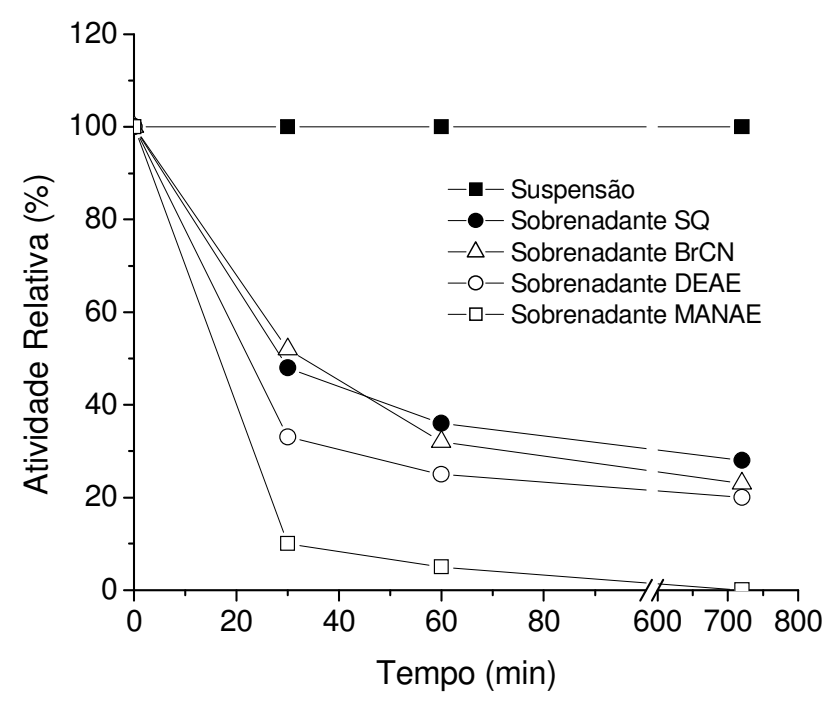

(A)

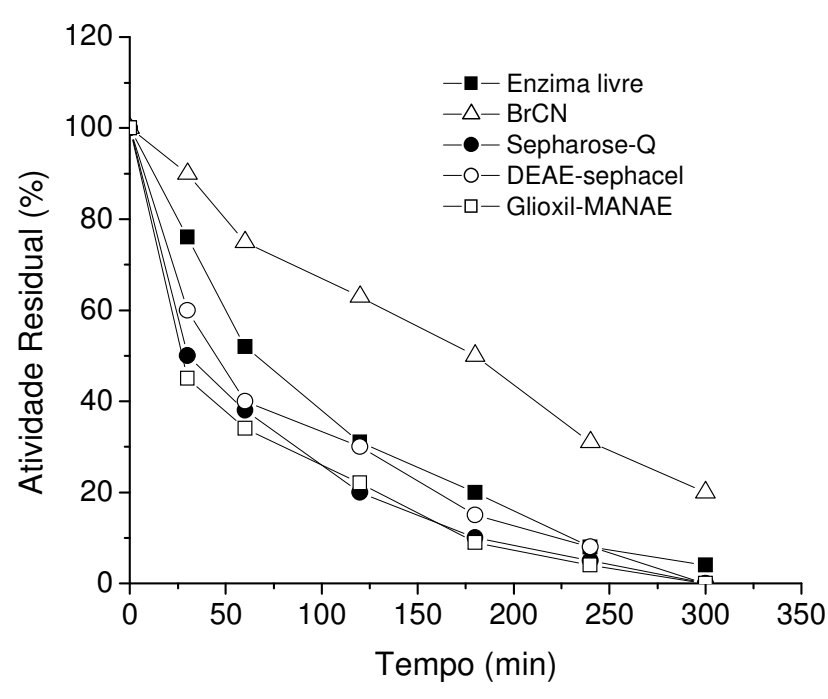

(B)

Figura 33: Cinética de imobilização de glucoamilase em BrCN, Sepharose-Q, Glioxil-MANAE e DEAE-Sephacel (A) e estabilidade térmica dos derivados a $60^{\circ} \mathrm{C}$ (B). 
4.30.1.1- Efeito da adição de trealose e dextrano sobre a estabilidade térmica da glucoamilase imobilizada

$\mathrm{Na}$ tentativa de melhorar a estabilidade térmica da glucoamilase imobilizada, trealose e detrano $70 \mathrm{kDa}$ em diferentes concentrações foram adicionados junto aos derivados (Figuras 34 e 35). Tanto a presença de trealose como a de dextrano proporcionaram aumento na estabilidade da enzima imobilizada. A melhor concentração de trealose para Sepharose Q e Glioxil MANAE foi de 20\% (Figuras 34 A e C). A melhor concentração de trealose para a estabilidade dos derivados DEAE e $\mathrm{BrCN}$ foi de 50 e $30 \%$ respectivamente (Figuras $34 \mathrm{~B}$ e D).

A presença de dextrano $70 \mathrm{kDa}$ como aditivo não proporcionou um aumento significativo quanto aquele apresentado quando adicionou-se trealose porém, é evidente o aumento na estabilidade dos derivados na sua presença. Em todas as ocasiões a concentração de $20 \%$ foi a melhor (Figura 35). 

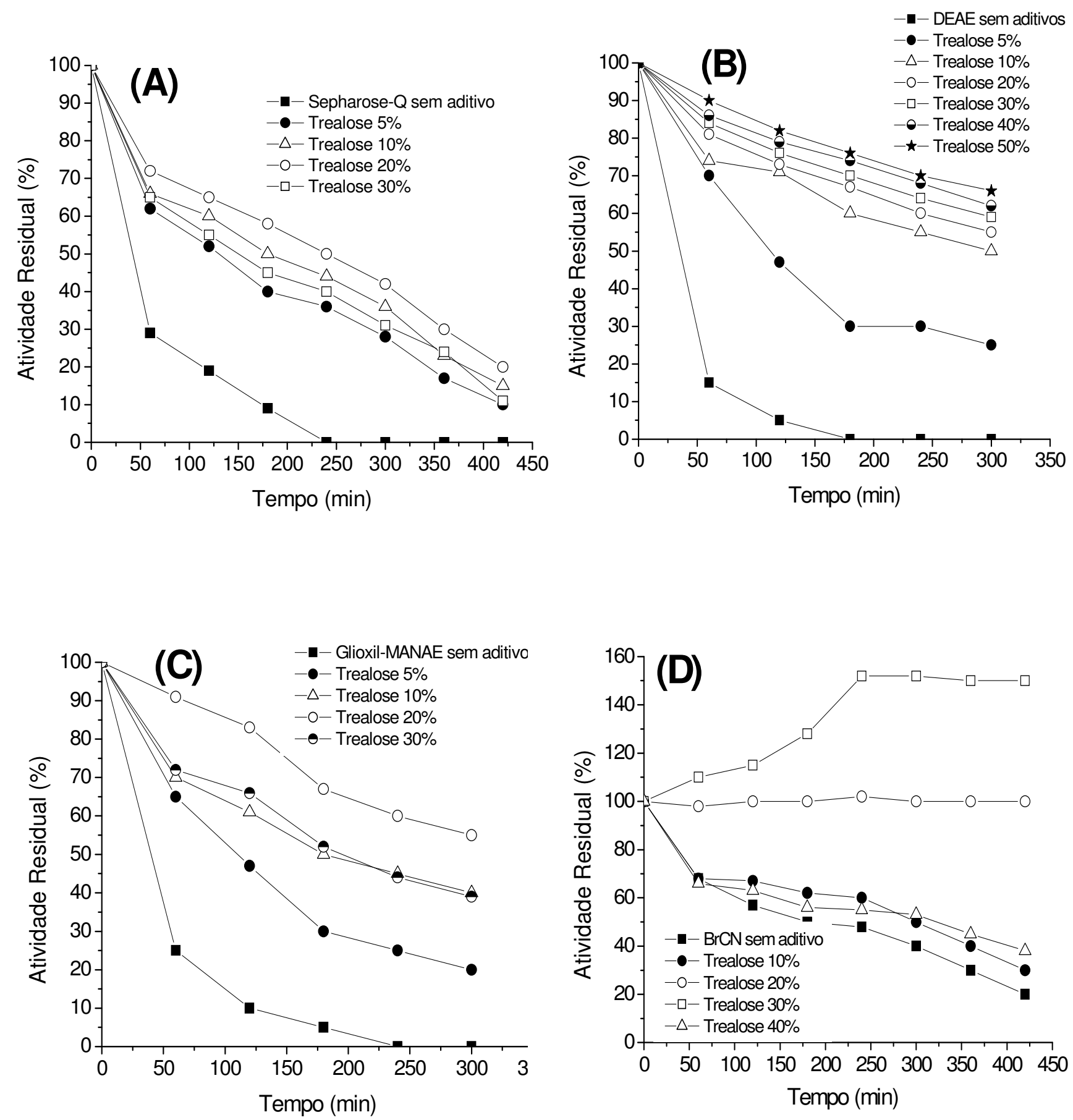

Figura 34: Estabilidade térmica da glucoamilase de A. niveus imobilizada em diferentes suportes em presença de trealose a $60^{\circ} \mathrm{C}$. A- Sepharose Q, B- DEAE-Sephacel, C- Glioxil-MANAE e D-BrCN. 

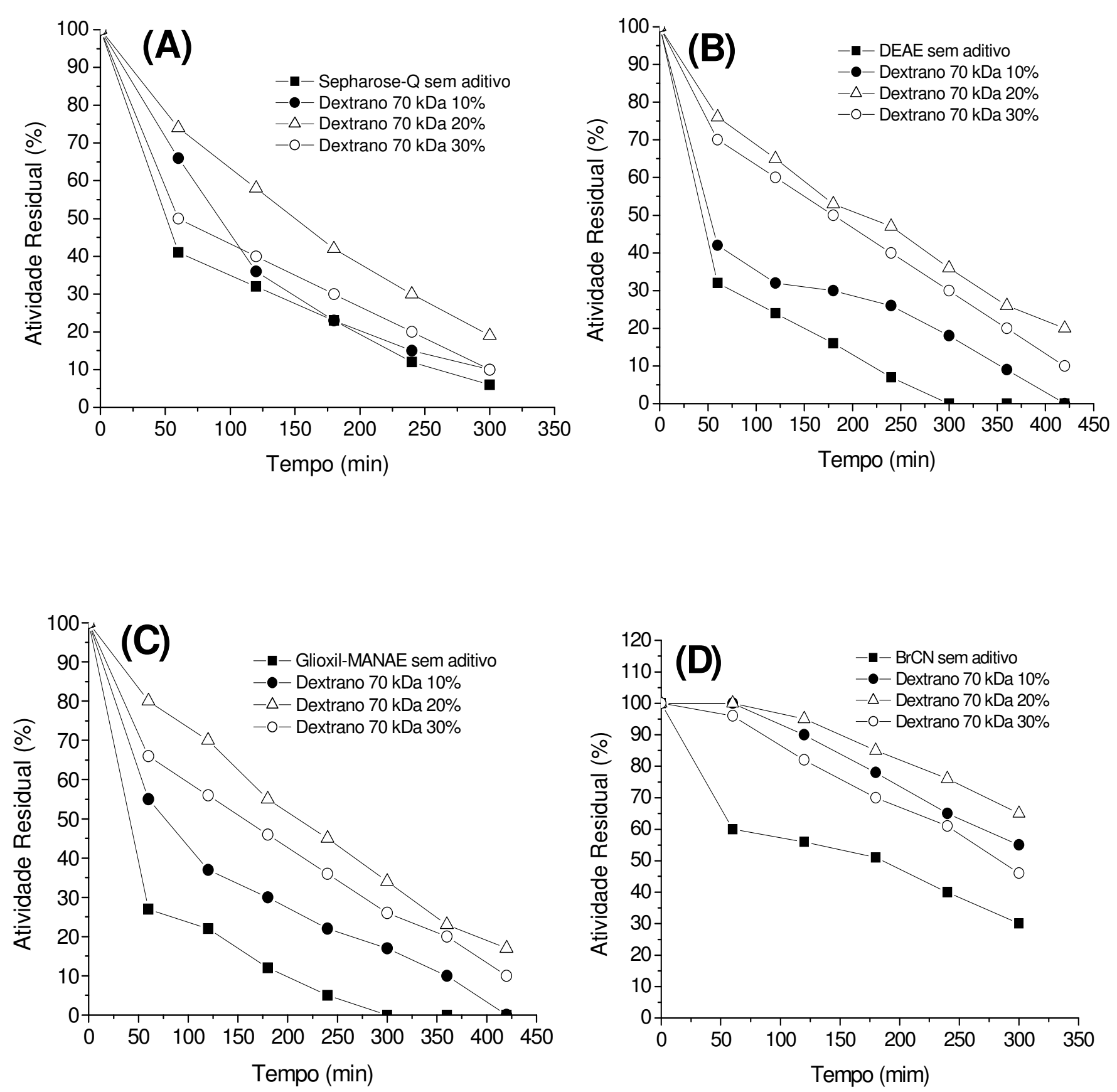

Figura 35: Estabilidade térmica da glucoamilase de A. niveus imobilizada em diferentes suportes em presença de dextrano a $60^{\circ} \mathrm{C}$. A- Sepharose Q, B-DEAE-Sephacel, C- Glioxil-MANAE e D-BrCN. 


\subsubsection{2- Efeito do pH na estabilidade de glucoamilase imobilizada em BrCN}

Essa etapa consistiu em avaliar o efeito do $\mathrm{pH}$ na estabilidade da glucoamilase de $A$. niveus imobilizada em $\mathrm{BrCN}$, na presença e ausência de trealose a 20\%. O derivado foi tratado com tampão fosfato de sódio a $100 \mathrm{mM}$ em pHs 5,0, 7,0 e 9,0. Os resultados (Figura 36) mostram que o $\mathrm{pH}$ exerce um efeito importante na atividade e estabilidade do derivado. Considerando a estabilidade do derivado na ausência de trealose, observa-se que em pH 5,0 a enzima é mais estável e que a pH 9,0 a estabilidade já está mais comprometida. Os derivados na presença de trealose a $20 \%$ apresentaram maiores estabilidades em todos os pHs, porém a maior diferença foi observada em pHs 7,0 e 9,0. Nessas condições o aditivo trealose passa a exercer maior influencia.

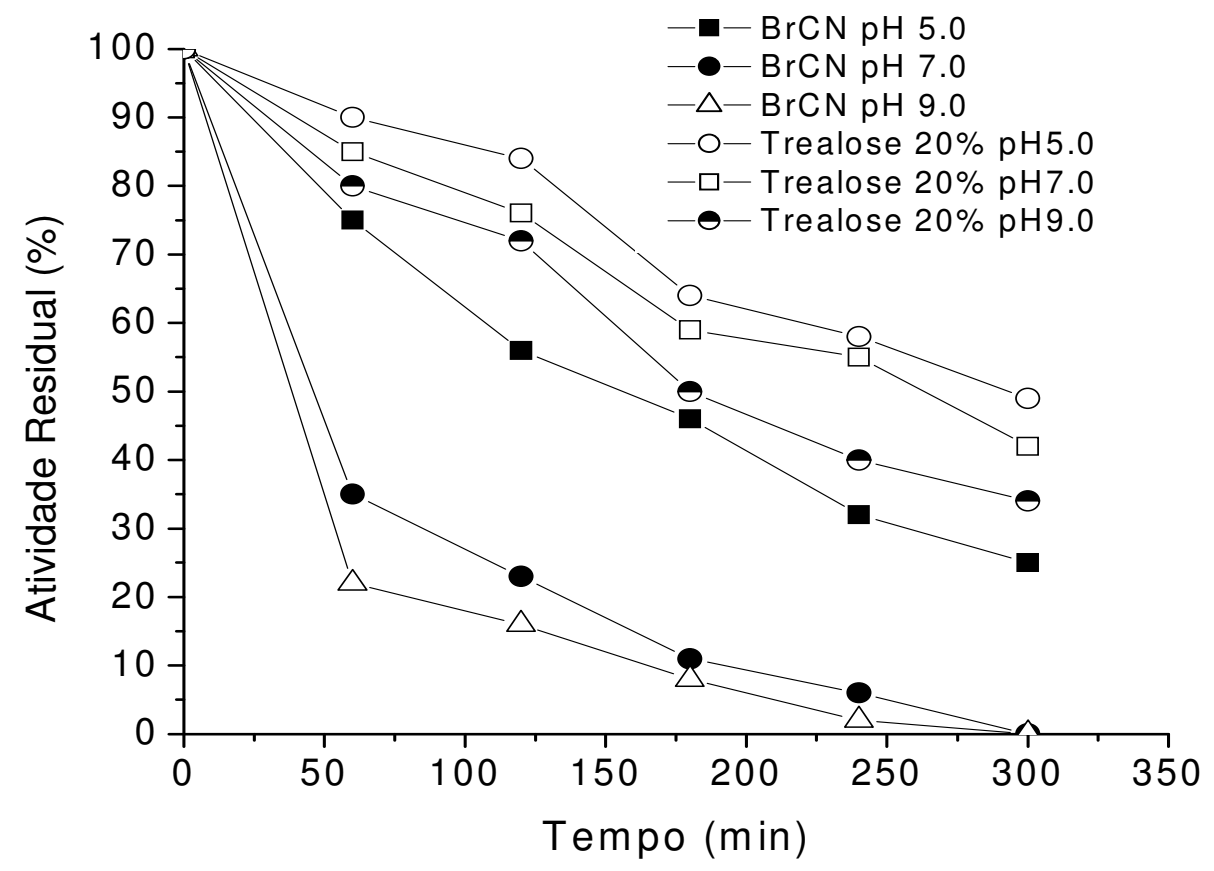

Figura 36: Efeito do $\mathrm{pH}$ na estabilidade térmica de glucoamilase imobilizada em $\mathrm{BrCN}$ na presença e ausência de trealose a $65^{\circ} \mathrm{C}$. 


\subsection{2- Imobilização de $\alpha$-glucosidase II}

Para a imobilização da $\alpha$-glucosidase $10 \mathrm{~mL}$ de solução enzimática foram misturados a $1 \mathrm{~g}$ dos suportes Glioxil-PEI, Sepharose Q, DEAE-Sephacel e BrCN. A cinética de imobilização desta enzima mostrou maior velocidade de adsorção pelos suportes trocadores iônicos e também pelo $\mathrm{BrCN}$ do que aquela apresentada para a glucoamilase. Em 60 minutos todas as enzimas estavam imobilizadas conforme mostra a Figura 37 A. Depois de preparados os derivados os mesmos foram colocados em banho a $60^{\circ} \mathrm{C}$ para análise de termoestabilidade. Não houve diferença na estabilidade dos derivados preparados com suporte trocadores iônicos comparados a enzima livre, porém o derivado obtido com $\mathrm{BrCN}$ foi mais estável (Figura 37 B).

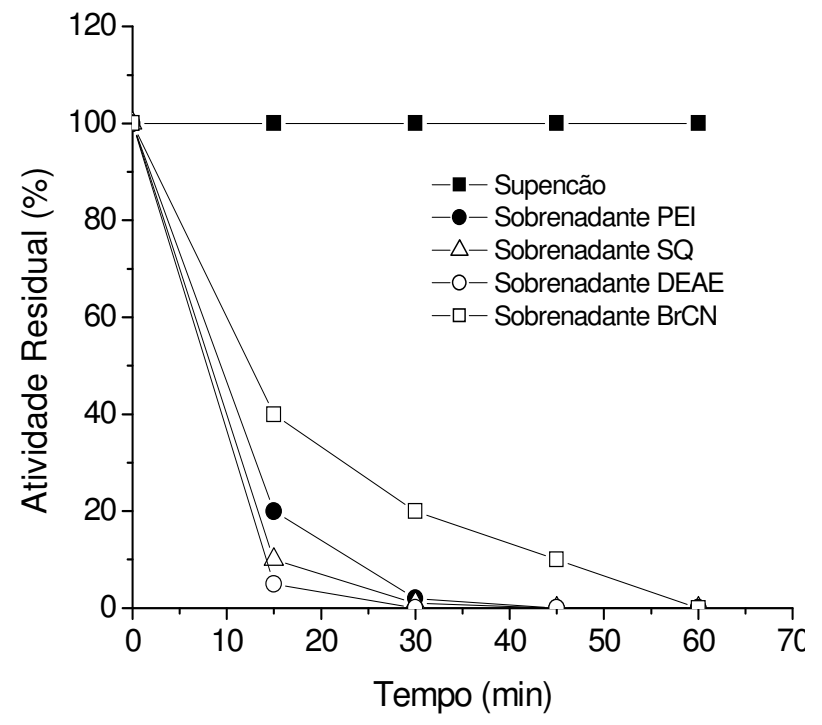

(A)

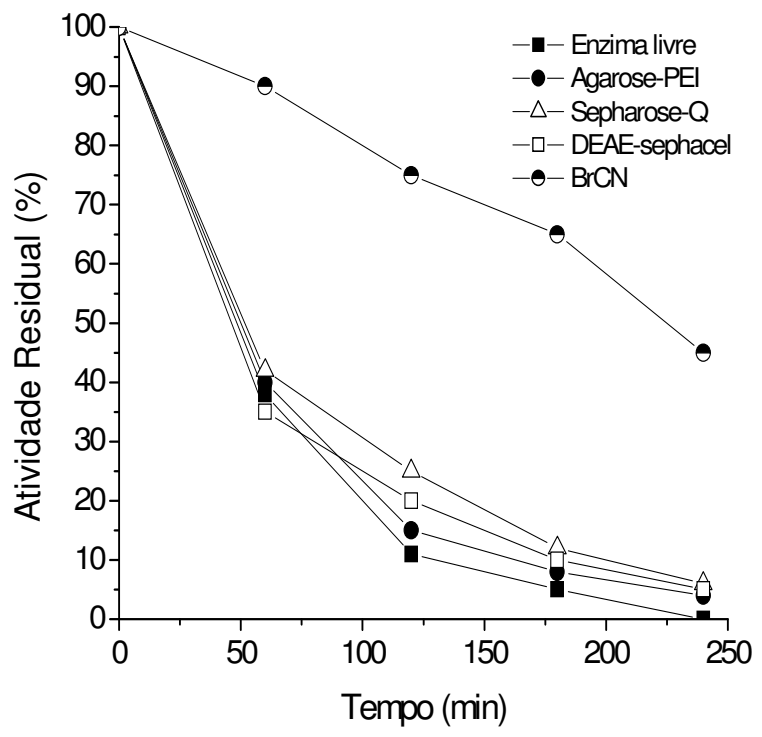

(B)

Figure 37: Cinética de imobilização de $\alpha$-glucosidase II em $\mathrm{BrCN}$, Sepharose-Q, Glioxil-PEI e DEAE-Sephacel (A) e estabilidade dos derivados a $60^{\circ} \mathrm{C}(\mathrm{B})$. 
4.30.2.1- Efeito da adição de trealose sobre a estabilidade térmica da $\alpha$-glucosidaseII imobilizada

Da mesma forma como ocorrido para a glucoamilase, os derivados obtidos com a $\alpha$ glucosidase II também foram avaliados na presença de trealose, conforme mostra a Figura 38. Aqui não foi possível fazer análise do efeito do dextrano como aditivo para a estabilidade dos derivados, pois a enzima mostrou uma alta afinidade por esse composto que foi rapidamente hidrolisado. O efeito aditivo da trealose sobre todos os derivados foi muito positivo e a melhor concentração foi de $20 \%$. 

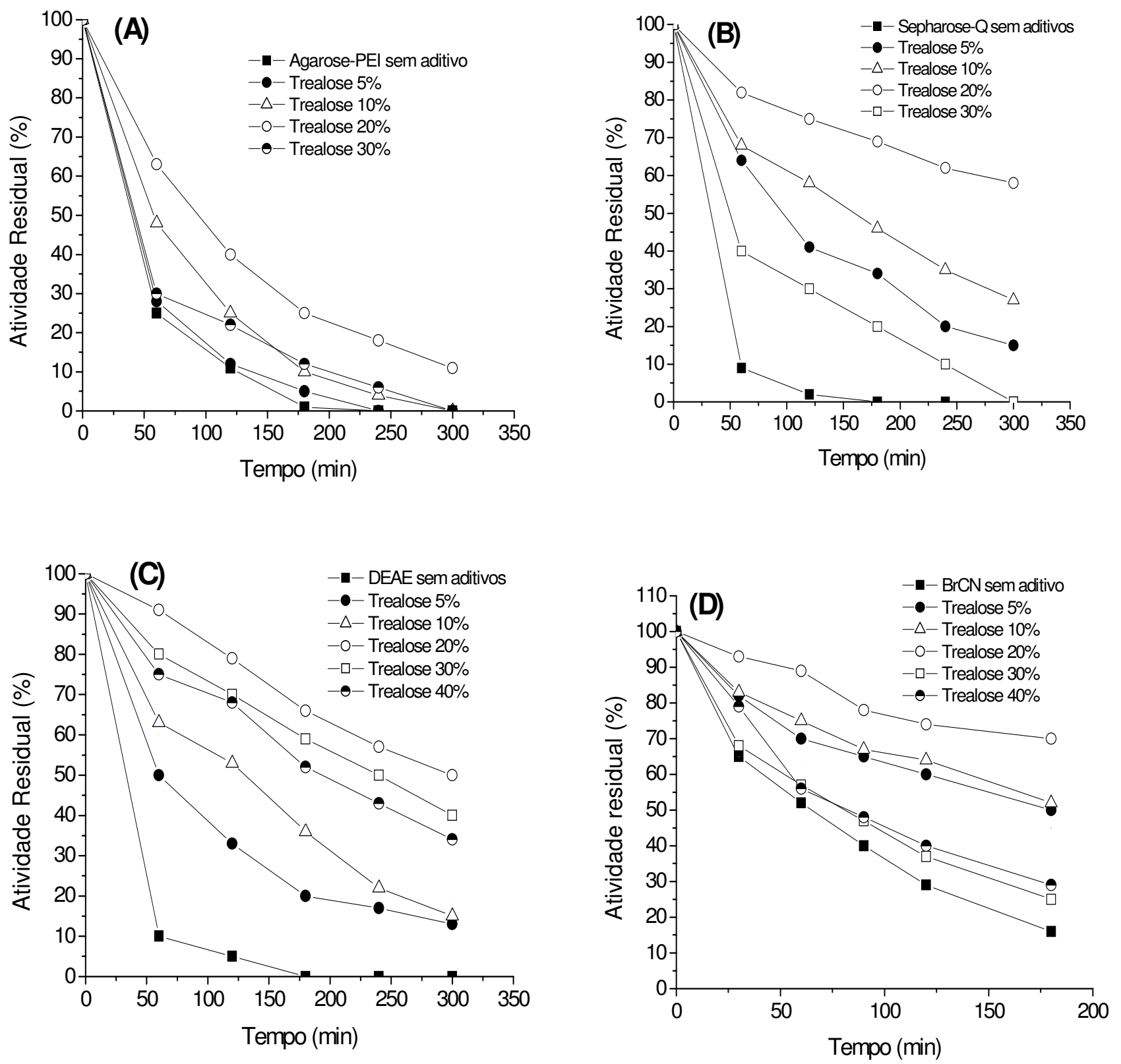

Figura 38: Estabilidade térmica de $\alpha$-glucosidase II de A. niveus imobilizada em agarose-PEI, Sepharose-Q, DEAE-Sephacel e $\mathrm{BrCN}$ a $60^{\circ} \mathrm{C}$. 


\subsubsection{2- Efeito do pH na estabilidade de $\alpha$-glucosidase II imobilizada em BrCN}

Assim como feito para glucoamilase, também foi avaliado o efeito do $\mathrm{pH}$ na estabilidade da $\alpha$-glucosidase II imobilizada em $\mathrm{BrCN}$, na presença e ausência de trealose a 20\%. O derivado foi tratado com tampão fosfato de sódio a $100 \mathrm{mM}$ em pHs 5,0, 7,0 e 9,0. Os resultados (Figura 39) mostram que a pH 5,0 não houve nenhuma diferença significativa na estabilidade do derivado com e sem trealose, já nos pHs 7,0 e 9,0 esta diferença foi mais acentuada.

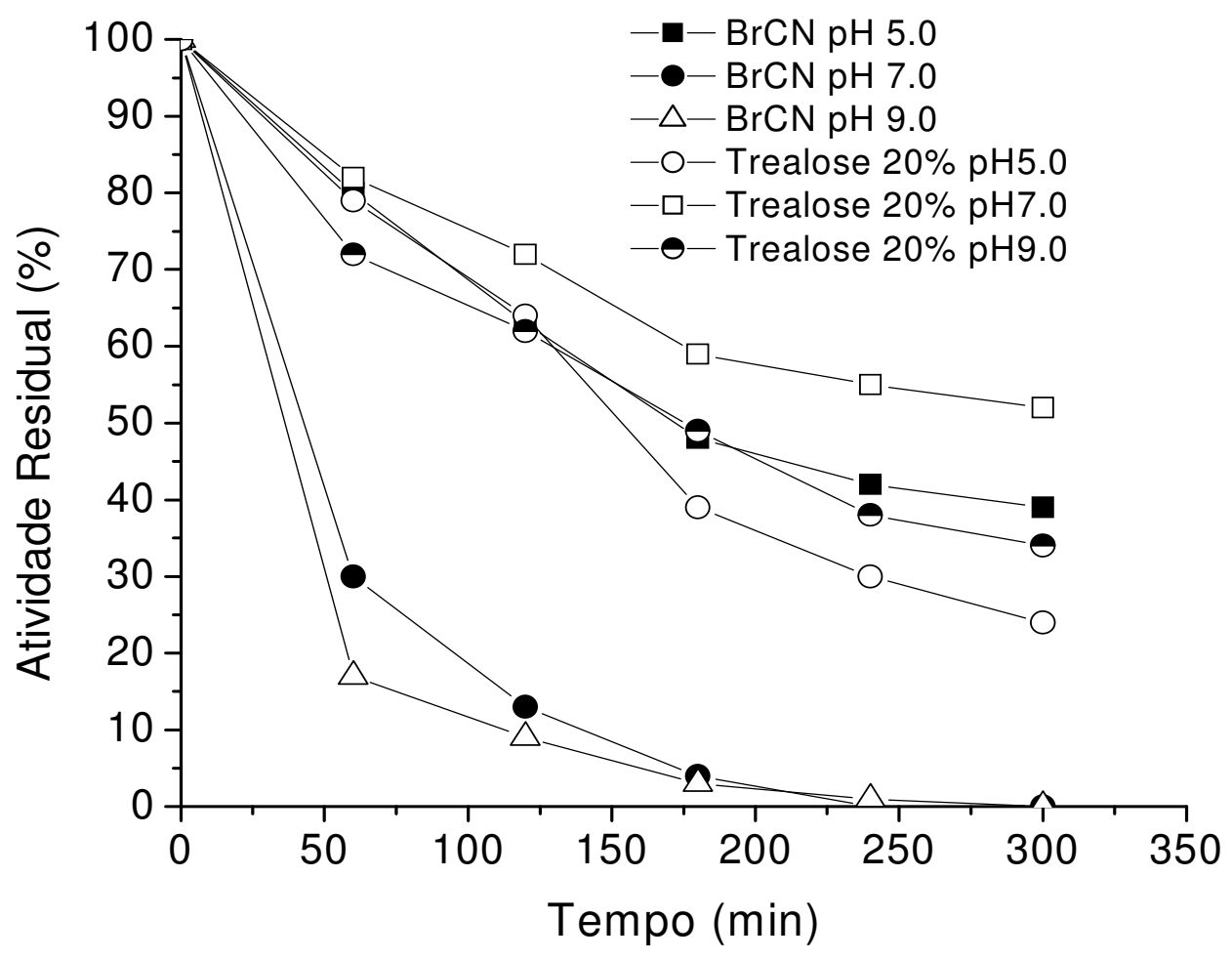

Figura 39: Efeito do $\mathrm{pH}$ na estabilidade térmica de $\alpha$-glucosidase II imobilizada em $\mathrm{BrCN}$ na presença e ausência de trealose a $63^{\circ} \mathrm{C}$. 


\subsection{3- Imobilização covalente de glucoamilase e $\alpha$-glucosidase II em glioxil-} agarose a pH 10,5

Nas etapas anteriores abordou-se a imobilização das amilases utilizando suportes trocadores iônicos e agarose ativada com brometo de cianogênio $(\mathrm{BrCN})$, o qual estabelece ligação do tipo covalente unipontual entre o suporte e a enzima, criando dessa forma um modelo de enzima livre para eventuais comparações. Outra forma de se estabelecer uma ligação covalente entre uma enzima e um suporte consiste em deixar as enzimas de interesse interagirem com o suporte glioxil agarose a $\mathrm{pH} 7,0$ para que haja um direcionamento da enzima ao suporte, através da ligação entre os grupos aminos terminais das enzimas com os grupamentos aldeídos do suporte. Depois de estabelecido esse direcionamento, eleva-se o pH para 10,5 para que os grupos aminos das lisinas, agora ativos, estabeleçam também ligações do tipo covalente com o suporte. A esse tipo de interação utilizando os grupos aminos das lisinas dá-se o nome de ligação covalente multipontual, e esse tipo de interação caracteriza-se por fornecer normalmente a enzima maior estabilidade em função do maior número de ligações com o suporte. Glucoamilase e $\alpha$-glucosidase II foram primeiro incubadas com Glioxil Agarose em $\mathrm{pH} 7,0$ e depois a $\mathrm{pH} 10,5$ por 12 horas para o estabelecimento das ligações multipontuais (Figura 40). 


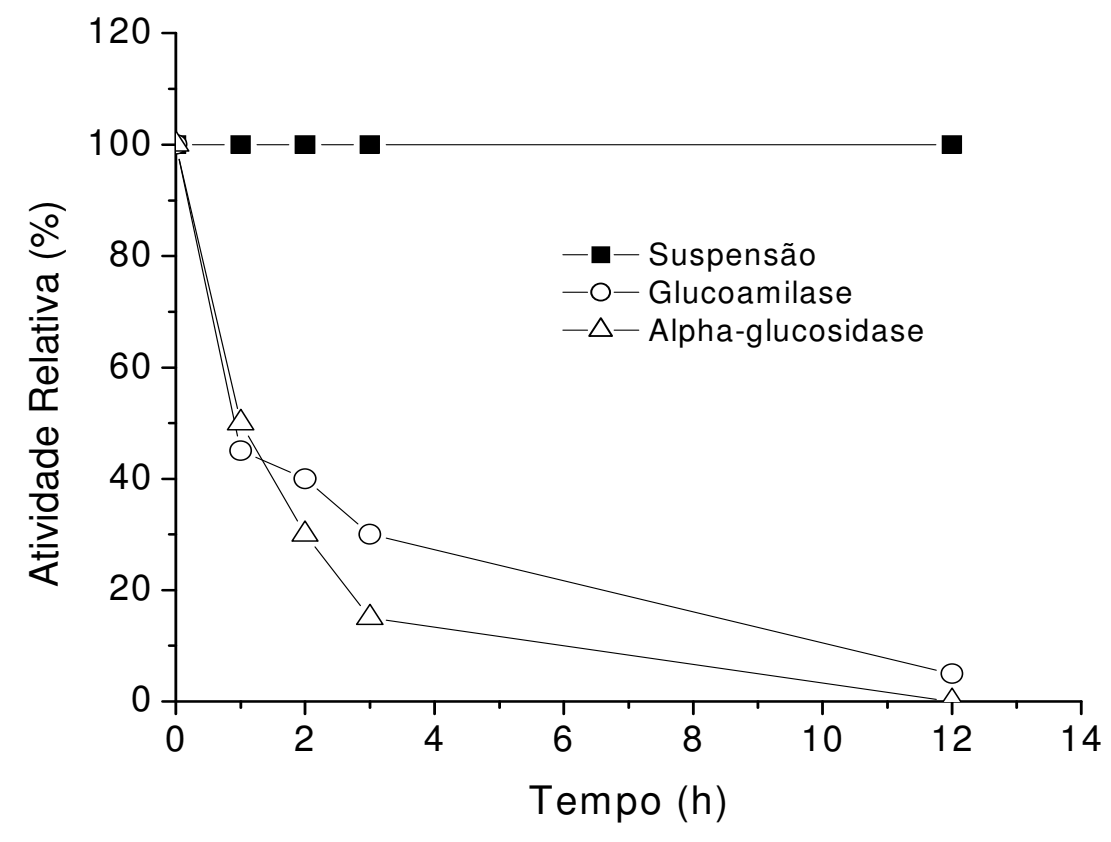

Figura 40: Cinética de imobilização covalente multipontual de glucoamilase e $\alpha$-glucosidase II em Glioxil Agarose a pH 10,5.

\subsubsection{1- Estabilidade térmica das amilases imobilizadas por ligações covalentes}

\section{multipontuais}

Depois de preparados os derivados através de ligações covalentes multipontuais, estes foram levados a banho sob temperatura de $60^{\circ} \mathrm{C}$ para glucoamilase e $63^{\circ} \mathrm{C}$ para $\alpha$-glucosidase II conforme mostra a Figura 41. Como já era esperado, os derivados oriundos de ligações multipontuais (Glioxil agarose), tanto para glucoamilase como para $\alpha$-glucosidase II mostraram-se mais estáveis que aqueles obtidos com ligação unipontual (BrCN) e enzimas livres. A $\alpha$-glucosidase II apresentou uma estabilidade significativamente maior que a glucoamilase. 


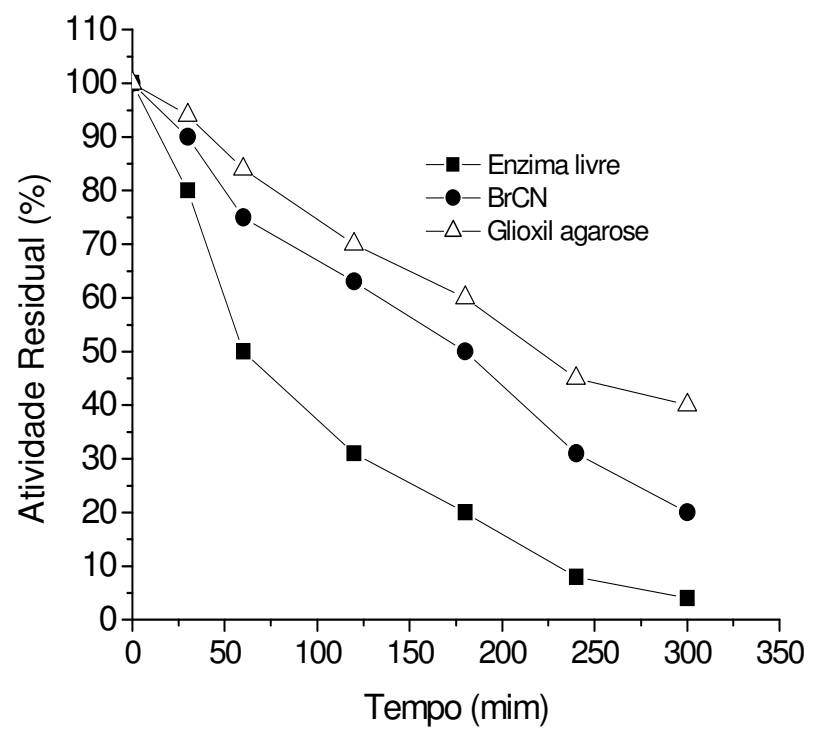

(A)

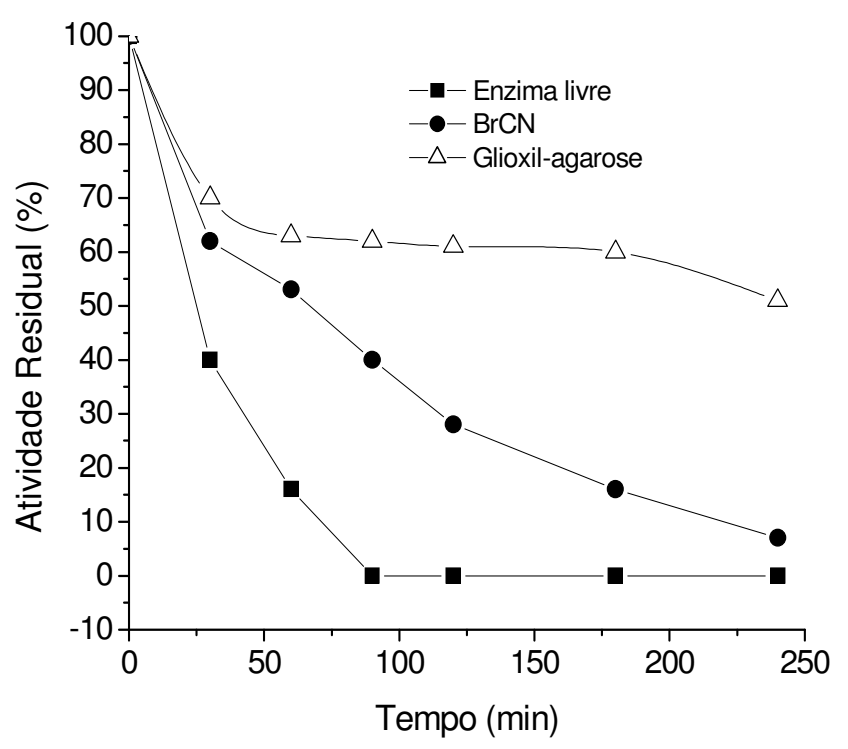

(B)

Figura 41: Estabilidade térmica de glucoamilase a $60^{\circ} \mathrm{C}(\mathrm{A})$ e $\alpha$-glucosidase II a $63^{\circ} \mathrm{C}(\mathrm{B})$.

\subsubsection{2- Uso da trealose como aditivo na estabilidade dos derivados com ligações} covalentes multipontuais

Assim como havia feito com os demais derivados, adicionou-se trealose em diferentes concentrações para avaliação do seu efeito protetor contra a desnaturação térmica. Os resultados (Figura 42) mostram que a trealose protegeu os derivados em todas as concentrações, porém, a melhor estabilidade foi verificada quando se utilizou $20 \%$. 


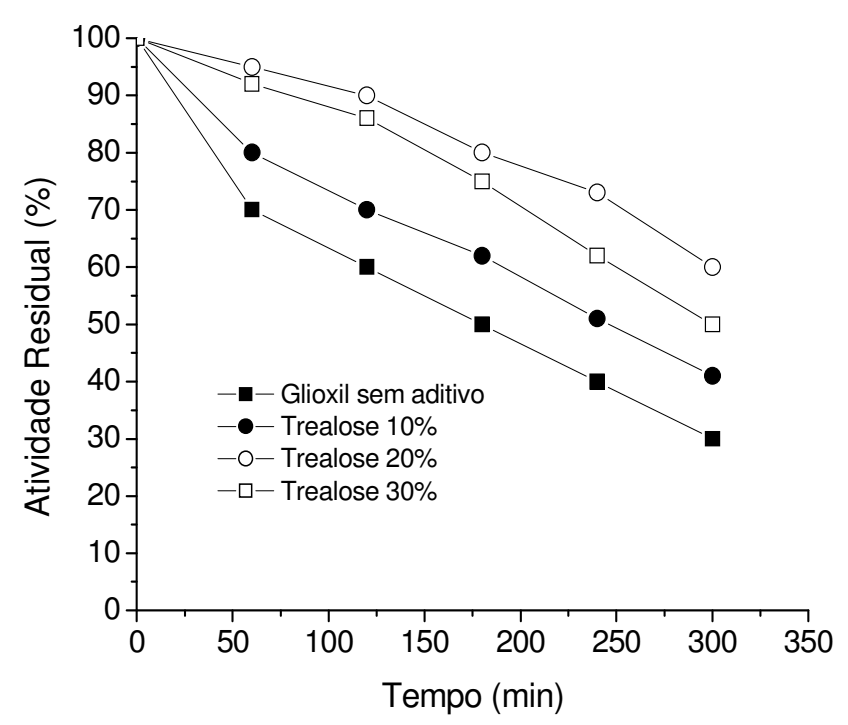

(A)

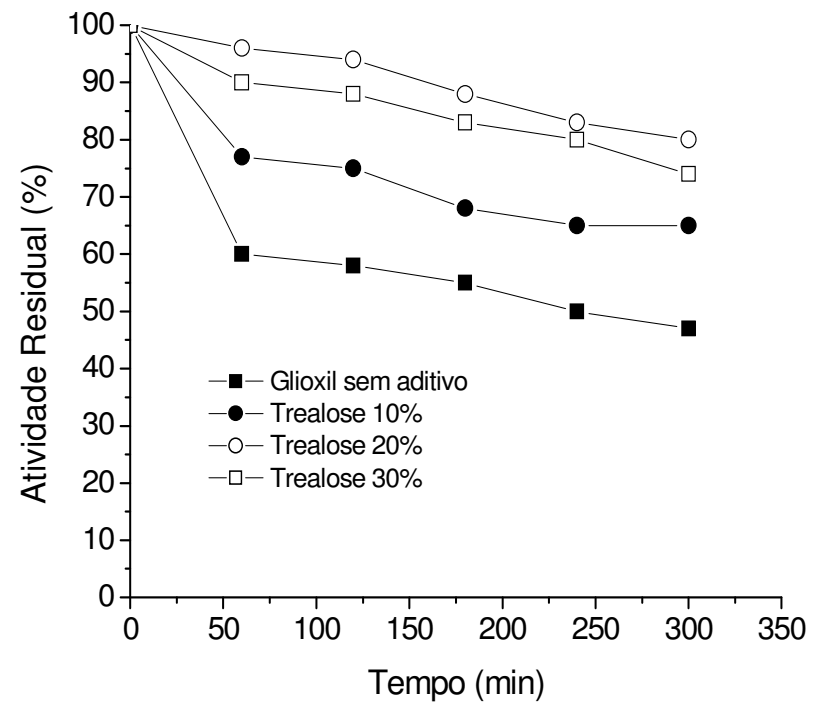

(B)

Figura 42: Efeito da trealose na estabilidade térmica das enzimas imobilizadas por ligações covalentes multipontuais. (A) derivado de glucoamilase a $60^{\circ} \mathrm{C}$ e (B) derivado com $\alpha$-glucosidase II a $63^{\circ} \mathrm{C}$.

\subsubsection{3- Efeito de aditivos glicerol, polietilenoglicol e trealose na reativação dos} derivados enzimáticos formados por ligações covalentes multipontuais após tratamento com guanidina

Depois de avaliados o efeito da trealose como agente estabilizante dos derivados enzimáticos foi realizado um estudo do efeito da trealose, glicerol e polietilenoglicol na reativação da atividade enzimática dos derivados após tratamento com guanidina a $8 \mathrm{M}$. Sabese que a guanidina é uma substancia cristalina obtida a partir da oxidação da guanina, e é conhecido também que essa substancia atua como um agente desestabilizante de proteínas por agir desordenando as suas estruturas até a perda da função. Os derivados de glucoamilase e $\alpha$ glucosidase II foram mantidos em contatos com a guanidina durante 5 minutos para total desnaturação das enzimas. Em seguida, os derivados foram lavados com tampão fosfato 100 $\mathrm{mM}$ a pH 7,0 e soluções de glicerol $10 \%$, polietilenoglicol $1,5 \mathrm{kDa}$ a $10 \%$ e trealose $20 \%$. Os 
resultados (Figura 43) mostraram que os aditivos foram muito eficientes na reativação dos derivados. Para o derivado obtido com a glucoamilase, em todas as condições, houve reestabilização da atividade enzimática, e a trealose foi a que proporcionou uma reativação mais rápida (Figura $43 \mathrm{~A}$ ). Para o derivado obtido com a $\alpha$-glucosidase II observou-se que apenas o uso do tampão não foi suficiente para a reativação de toda a atividade enzimática, e da mesma forma ocorreu com Glicerol e polietilenoglicol, porém estes foram melhores que o tampão. Quando se fáz o uso da trealose, verificou-se uma reabilitação instantânea da atividade da enzima (Figura 43 B).

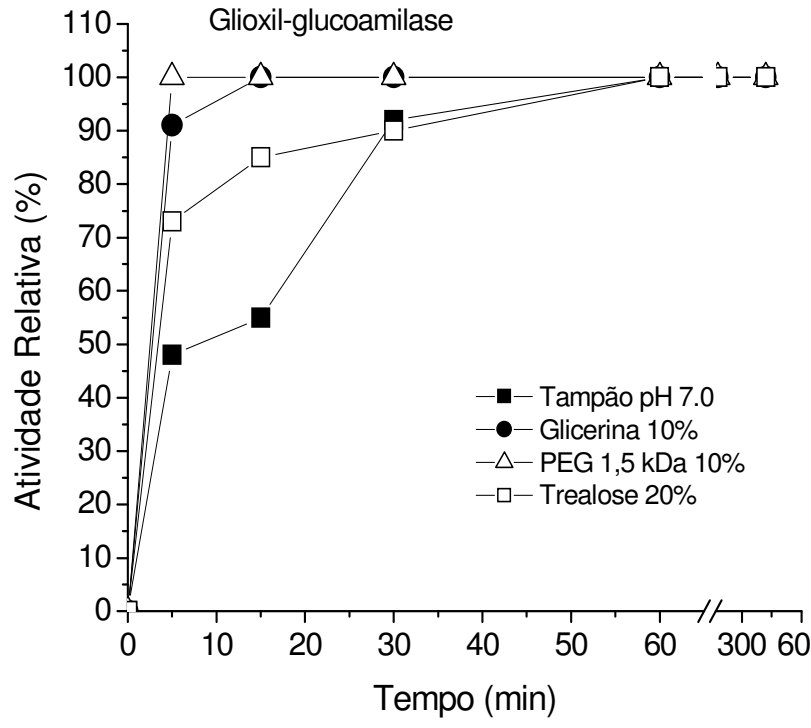

(A)

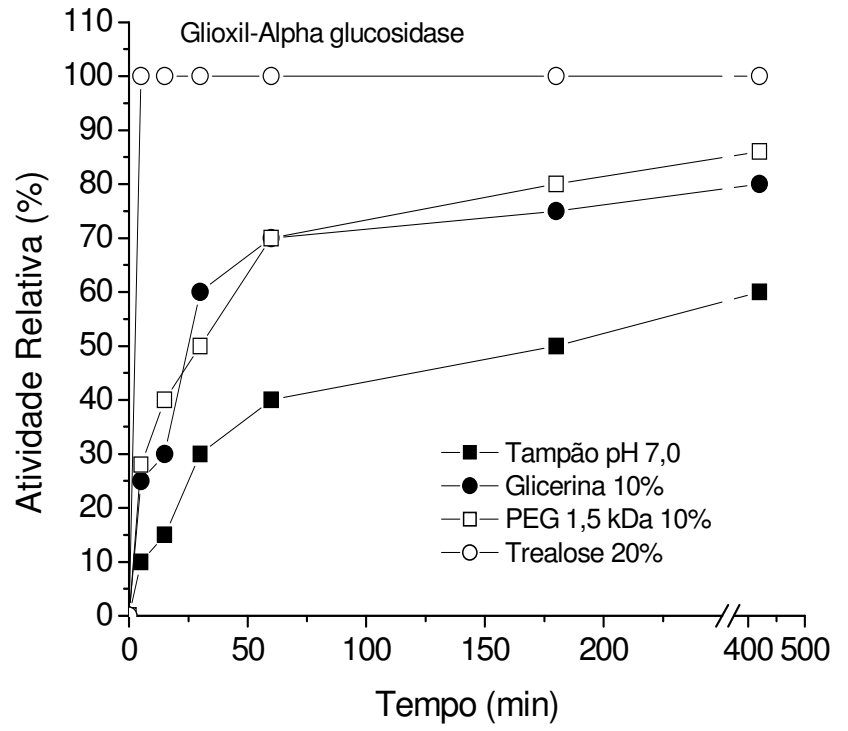

(B)

Figura 43: Efeito de aditivos glicerina, polietilenoglicol e trealose na reativação de glucoamilase (A) e $\alpha$-glucosidase II (B) de A. niveus imobilizadas em Glioxil-agarose. 


\section{V- DISCUSSÃO}

$\mathrm{O}$ isolamento de fungos filamentosos de amostras de solo tem sido freqüente e é possível pela presença de esporos que conferem a estes microrganismos resistência às condições desfavoráveis que o ambiente oferece. Dessa forma, foi possível isolar uma significativa quantidade de cepas oriundas de material de solo, tais como folhas em decomposição, fezes animais e material em compostagem nas três coletas realizadas. A busca de cepas em amostras de silagem, que tem o amido como uma das substâncias de reserva, aumenta a possibilidade de se encontrar linhagens amilolíticas, uma vez que o tipo de microrganismo que está presente na microflora daquele ambiente está relacionado com as oportunidades nutricionais oferecidas naquele momento. Cabe aqui destacar que silagem de milho oferece além do amido, outras substâncias que, por conversão enzimática formam compostos assimiláveis pelos microrganismos, constituindo dessa forma de um ambiente para microrganismos não amilolíticos.

A hidrólise enzimática do amido é uma das mais importantes reações enzimáticas ocorridas em escala industrial. As enzimas envolvidas no processo de degradação do amido são as amilases e entre elas estão as glucoamilases, $\alpha$-amilases e $\alpha$-glucosidases. As glucoamilases são caracterizadas como exoenzimas que produzem $\beta$-D-glicose a partir da extremidade não-redutora da cadeia de amilose, amilopectina e glicogênio pela hidrólise de ligações do tipo $\alpha-1,4$ por meio da remoção de sucessivas unidades de glicose. Estas enzimas são oriundas de várias fontes como plantas, animais e microrganismos em geral e catalisa eficientemente a reação de sacarificação do amido dentro de um limite estreito de temperatura, isto porque a conformação cataliticamente ativa das glucoamilases hoje usadas na indústria é alterada com o aumento da 
temperatura, o que afeta seu uso no processo industrial, onde a conservação prolongada em altas temperaturas é necessária. As glucoamilases comercialmente disponíveis são, em sua maior parte, produzidas por linhagens de Aspergillus e Rhizopus. As glucoamilases de Aspergillus são mais termoestáveis, com atividade máxima em temperaturas entre 50 e $55^{\circ} \mathrm{C}$, sendo elas rapidamente inativadas em temperaturas próximas de $60^{\circ} \mathrm{C}$ (ZAHA \& ZEIKUS, 1989).

$\alpha$-glucosidases (EC 3.231.20 $\alpha$-D-glucosídeo glucohidrolases) são enzimas de origem microbiana e hidrolisam as ligações $\alpha-1,4$ e $\alpha-1,6$ de oligossacarídeos de cadeia curta, os quais são formados pela ação de outras amilases, liberando unidades de $\alpha$-D-glicose a partir da extremidade não redutora (VIHINEN \& MÄNTSÄLÄ, 1989). Essas enzimas são convencionalmente classificadas de acordo com a especificidade ao substrato. O tipo I, hidrolisa glicosídeos aril, tais como $p$-nitrofenil $\alpha$-D-glucopiranoside ( $\rho \mathrm{NPG}$ ) mais rapidamente do que pequenos maltooligossacarídeos. O tipo II é mais ativo sobre a maltose e tem pouca atividade sobre glicosídeos aril. O tipo III se assemelha ao tipo II, porém hidrolisa oligossacarídeos e amido com a mesma velocidade (MARÍN et al., 2006).

Segundo VIHINEN \& MÄNTSÄLÄ (1989) glucoamilases liberam $\beta$-D-glicose a partir da extremidade não redutora da molécula de amido, enquanto que $\alpha$-glucosidases liberam $\alpha$-D-glicose. De acordo com LEHNINGER et al. (2005), as duas conformações anoméricas da molécula de glicose tenden a estabelecer um equilíbrio, dificultando dessa forma, uma análise precisa de qual anômero estaria sendo liberado e também qual enzima estaria envolvida no processo. Em função disso, outros métodos de identificação enzimática foram adotados em nossos ensaios tais como, hidrólise de substratos sintéticos como o $p$ nitrofenil $\alpha$-D-glucopiranoside ( $\rho$ NPG) e uso do sequencianmento de aminoácidos. 
As 19 linhagens isoladas nas três coletas e as anteriormente isoladas durante o projeto Biota demonstraram excelente capacidade de crescimento e produção das amilases em fermentação líquida, tendo amido solúvel como única fonte de carbono, porém, a linhagem de A. niveus produziu as enzimas de interesse em quantidades significativas, além de que não aparece na literatura como uma linhagem produtora de amilases. Um outro fator que determinou nossa escolha por esse fungo foi o fato de o mesmo já ter sido identificado, o que evitaria o risco de trabalhar com linhagens já estudadas e também patogênicas.

Após a escolha de A. niveus como o melhor produtor de amilases, alguns meios de cultura foram testados para avaliar o crescimento e a produção enzimática. Os resultados mostraram que o meio Khanna em condições física de cultivo estático foi o mais adequado, tanto no suprimento das necessidades fisiológicas, quanto na síntese das enzimas. Esse mesmo meio, com pequenas modificações foi o que melhor induziu a síntese de amilases por Aspergillus phoenicis em fermentação líquida (BENASSI, 2006). Com relação a concentração de inóculo, ficou estabelecido que 5,0 x $10^{5}$ conídios $/ \mathrm{mL}$, proporcionou o melhor crescimento e também os maiores índices de atividade amilásica. A atividade máxima de amilases de Paecilomyces variotii foi determinada quando $1,75 \times 10^{8}$ conídios $/ \mathrm{mL}$ foram inoculados (MICHELIN, 2005)

O maior crescimento de A. niveus foi verificado em 48 horas de cultivo e a maior atividade enzimática verificada em 72 horas. Sabe-se que o crescimento microbiano dividi-se em quatro fases, sendo elas, a fase de adaptação do microrganismo no meio de cultivo (fase LAG), uma fase caracterizada por um crescimento rápido e uniforme (fase LOG), a qual o microrganismo já adaptado ao meio, utiliza-se de todos os recursos oferecidos por este para o seu desenvolvimento, uma fase estacionária na qual o crescimento do microrganismo é interrompido devido a escassez nutricional do meio e uma fase de declínio, onde o meio além 
de não oferecer mais condições nutricionais também dispõe de uma série de compostos oriundos do metabolismo do próprio microrganismo, os quais são responsáveis pela lise das hifas e conseqüentemente morte celular. Ainda com relação aos resultados referentes ao tempo de cultivo foi possível observar que A. niveus foi hábil na adaptação ao meio, sendo esse período quase não evidenciado. A fase de crescimento exponencial foi bem verificada nas primeiras 24 horas de crescimento sendo o seu término verificado por volta de 48 horas. Nessa fase, o microrganismo teria necessidade de recursos prontamente assimiláveis garantindo a sua sobrevivência no meio, assim, justifica-se o pico de atividade por volta de 72 horas de cultivo, uma vez que nesse período o amido estaria sendo degradado pelas enzimas para o consumo do fungo. A partir de 72 horas foi possível observar um declínio no crescimento, provavelmente devido à escassez nutricional e também por excesso de compostos oriundos do metabolismo e que foram secretados para o meio. ARNESEN e colaboradores (1998), ao estudarem a produção de $\alpha$-amilase por T. lanuginosus obtiveram picos de produção entre 96 e 120 horas. CRUZ e colaboradores (1997) determinaram o mesmo tempo de cultivo para a maior produção de $\alpha$-amilase por Rhizopus sp.

Meios de cultivos com pHs iniciais próximos a neutralidade favoreceram a produção das amilases pelo fungo em estudo, embora este tenha mostrado capacidade de crescimento em todos os pHs testados. $\mathrm{O} \mathrm{pH}$ inicial de 6,5 foi tomado como o mais adequado para a produção de amilases por A. niveus, dado este, que coincide com os de GOTO e colaboradores (1998) e os de BENNAMOUN e colaboradores (2004) que determinaram esse mesmo valor de pH inicial para a produção de amilases por A. fumigatus e A. oryzae Ahlburg (Cohen) 1042.72, respectivamente. A maior produção de glucoamilase por Aspergillus sp. A3 ocorreu em meio de cultivo com pH inicial 5,0 (ELLAIAH, 2002). 
Ainda com relação ao $\mathrm{pH}$ do meio, foi possível observar que após o término do processo fermentativo os valores de $\mathrm{pH}$ foram superiores àqueles iniciais de meio de cultivo, variando-se entre 7,0 e 7,65. Segundo RAIMBAULT (1998), os valores de pH durante o processo fermentativo podem aumentar ou diminuir em função dos produtos do metabolismo do microrganismo durante a fermentação. A secreção de ácidos orgânicos como ácido acético, ácido lático e ácido cítrico proporciona um decréscimo nos valores de $\mathrm{pH}$ e por outro lado, a assimilação de ácidos orgânicos, juntamente com a hidrólise de algumas substâncias como uréia e proteínas, geralmente causam um aumento no $\mathrm{pH}$ do meio de cultivo.

Assim como o pH, a aeração, a fonte de carbono, a temperatura tem importante influência sobre o crescimento e secreção das enzimas pelos microrganismos. Dessa forma, é importante o conhecimento da temperatura mais apropriada para a síntese e secreção das enzimas pelo microrganismo. A temperatura é um dos fatores ambientais mais importantes que afetam o crescimento e a sobrevivência dos microrganismos. Cada organismo apresenta uma temperatura mínima, abaixo da qual é incapaz de crescer, e uma temperatura máxima, acima da qual ocorre a morte da célula microbiana. A temperatura ótima de crescimento de um organismo sempre se encontra mais próxima da temperatura máxima do que da temperatura mínima (MADIGAN et al., 2003).

A maior parte das amilases fúngicas descritas são produzidas por organismos mesofílicos cujas temperaturas de crescimento variam de 25 a $37^{\circ} \mathrm{C}$ (GUPTA et al., 2003). A temperatura ótima para a produção de amilases pelas linhagens mesofílicas de A. oryzae, A. tamarii, Rhizopus oligosporus, A. oryzae, Aspergillus sp e Cryptococuus flavus foram de 30, 30, 35, 30, 35 e $25^{\circ} \mathrm{C}$, respectivamente (CARLSEN et al., 1996; MOREIRA et al., 1999; JIN et al., 1999; ELLAIAH et al., 2002; FRANCIS et al., 2003 e WANDERLEY et al., 2004). Dentre os termofilicos descritos como amilolíticos destacam-se Thermonospora fusca e $T$. 
lanuginosus os quais produzem $\alpha$-amilase a $55^{\circ} \mathrm{C}$ e $50^{\circ} \mathrm{C}$, respectivamente $(\mathrm{BUSCH} \&$ STUTZENBERGER 1997; JENSON et al., 1988). A temperatura ótima para a produção de amilases pelas linhagens de Rhizopus microsporus var rhizopodiformis, T. lanuginosus (ATCC 34626) e Rhizomucor pusilus A 13.36 foram de 45, 45, 47 e $45^{\circ} \mathrm{C}$ (PEIXOTO et al., 2003; NGUYEN et al., 2002; SILVA et al., 2005), respectivamente.

Amido e amiláceos têm sido descritos como os substratos mais adequados para a alta produtividade de amilases (ALI \& HOSSAIN, 1991; KILIKIAN, 1996; PEIXOTONOGUEIRA, 2008). Nesse caso, o aproveitamento de resíduos agrícolas ou de processamento de amido, os quais contêm quantidades residuais de amido suficientes para esse fim, constitui uma das alternativas mais viáveis. O uso de resíduos agro-industriais para a produção enzimática fornece substratos alternativos, por outro lado, ajuda a solucionar os problemas de poluição que o descarte dos mesmos pode causar no ambiente. Varias fontes de carbono foram testadas e o microrganismo em estudo foi capaz de crescer e sintetizar as enzimas em todas elas. Milho moído, farinha de aveia, palha de arroz, maizena, amido solúvel comercial e maltose foram as fontes que mais induziram a síntese enzimática. Foi possível observar um ligeiro crescimento do microrganismo em meio de cultivo sem fonte de carbono e conseqüentemente uma pequena produção enzimática. Isso pode ser explicado pelo fato de haver no meio de cultivo, sais, proteínas e vitaminas provenientes do extrato de levedura o que seria aproveitado pelo fungo para o crescimento, mesmo não havendo uma fonte de carbono. Quanto as enzimas determinadas, fica evidente que trata-se de enzimas constitutivas, uma vez que não encontra-se presente uma fonte indutora.

A presença de glicose nos meios de cultivo reprimiu a síntese das enzimas. Segundo TRABULSI e colaboradores (2004), pelo principio geral da economia celular, retirar precursores prontos do meio é sempre mais vantajoso do que sintetiza-los, ou seja, para o 
microrganismo seria uma desvantagem consumir energia para a síntese de uma macromolécula (amilase), para que a mesma atue sobre uma fonte de carbono complexa (amido), resultando na formação de glicose, que é prontamente assimilada para a obtenção de energia, sendo que a mesma já faz parte da constituição do meio de cultivo. CARLSEN e colaboradores (1996) estudando a produção de $\alpha$-amilase por $A$. oryzae verificaram que uma pequena concentração de glicose no meio de cultivo era suficiente para causar uma repressão na síntese dessa enzima. Uma situação semelhante foi observada por RAMACHANDRAN e colaboradores (2004) com a produção de $\alpha$-amilase por A. oryzae em presença de maltose.

Os produtos de hidrólises do amido a $1 \%$ pelas amilases do extrato bruto de A. niveus foram analisados por cromatografia de camada delgada. Os resultados revelaram a presença de glicose, maltose e maltotriose no hidrolisado, quando as enzimas utilizadas na hidrólise foram provenientes de meio de cultivo contendo amido solúvel e maltose como fonte de carbono indutora. Quando as enzimas utilizadas na hidrólise do amido solúvel foram oriundas de meios de cultivos com glicose, palha de arroz e maizena, os produtos de hidrólise consistiram de glicose e maltose. Esses dados sugerem que possa haver diferenças na indução das enzimas em função da fonte de carbono utilizada. Cabe aqui ressaltar que as fontes de carbono utilizadas para a síntese das enzimas apresentam diferenças nas suas constituições, quanto estrutura e isso possivelmente estaria determinando a síntese das enzimas conforme necessidade do microrganismo em degradar a fonte de carbono presente no meio. Com relação a hidrolise de amidos de diferentes fontes, foi também verificada uma ótima capacidade hidrolítica na maioria dos substratos testados. Amido solúvel e farinha de mandioca foram os mais susceptíveis ao ataque das enzimas. As diferenças observadas na atividade enzimática nos diferentes substratos estão relacionadas à própria estrutura do amido, as quais são diferentes em função da origem do polissacarídeo. As enzimas amilolíticas podem 
ou não atuar sobre o grânulo de amido, conforme o tamanho, bem como a organização interna do mesmo e a proporção de amilose. Segundo THARANATHAN e colaboradores (1980), a diferença na ação das enzimas amilolíticas sobre amidos de diferentes fontes, está diretamente relacionada com as diferenças na composição das moléculas, em particular no teor de amilose, bem como no comprimento de suas cadeias.

Em geral, amidos de cereais apresentam maiores teores de amilose, se comparados com amidos de raízes e tubérculos (batata e mandioca), que contem cerca de $20 \%$. Além disso, as cadeias de amilose dos amidos de cereais em geral, encontram-se associadas a moléculas de lipídios, que diferem no tipo e quantidade. Esse complexo amilose-lipídio diminui a susceptibilidade da amilose ao ataque das enzimas (CUI \& OATES, 1999). Segundo DREHER (1984), a própria associação entre os componentes do grânulo o torna mais ou menos susceptível ao ataque das enzimas. Outro fator que atua de forma decisiva na atividade das enzimas sobre os grânulos de amido, é a porosidade do mesmo (HUBER \& BEMILLER, 1997).

Os ensaios realizados com extrato enzimático bruto, na avaliação da ação das amilases de $A$. niveus sobre diferentes substratos mostraram que essas enzimas apresentam um grande potencial para aplicação em processos biotecnológicos, as quais estão envolvidas. As enzimas hidrolisaram eficientemente, amido, derivados de amido de cadeias longas e derivados de amido de cadeias curtas. Esses dados nos permitiram inferir que mais de uma forma enzimática está sendo sintetizada pelo fungo, o que garante a esse microrganismo maior sucesso na exploração desses substratos. Essas formas enzimáticas (dextrinizantes e sacarogênicas) são comumente sintetizadas por esses organismos. A hidrolise da maltose, maltotriose e glicogênio sugerem a presença de glucoamilases. 
Aspergillus niveus produziu altos níveis de glucoamilase, $\alpha$-glucosidase I e $\alpha$ glucosidase II em meio contendo amido como fonte de carbono indutora. As três enzimas foram purificadas utilizando-se de eluição em cromatografias de troca iônica e de afinidade (Concanavalina A-Sepharose) para a glucoamilase, e troca iônica (DEAE-Fractogel) e filtração em gel (Sephacryl S-200) para $\alpha$-glucosidase I e $\alpha$-glucosidase II. Ao final das duas etapas de eluição foi possível determinar um grau de recuperação de 47,5 e um fator de purificação de 2,5 para glucoamilase, uma recuperação de 3,6 e um fator de purificação de 2,61 para a $\alpha$-glucosidase I, e um grau de recuperação e fator de purificação para $\alpha$ glucosidase II de 7,35 e 2,27, respectivamente, em relação ao extrato enzimático. Com relação a DEAE-Fractogel a recuperação foi de $32,7 \%$ para a $\alpha$-glucosidase I e $66,8 \%$ para a $\alpha$ glucosidase II, totalizando uma recuperação de $95 \%$ no final do processo.

A etapa seguinte a eluição consistiu em caracterizar as enzimas em gel de poliacrilamida em condições não desnaturante (PAGE) e desnaturante (SDS-PAGE). Em todos os géis as enzimas aparecem puras e com atividade em gel 5\% polimerizado com amido solúvel. A mesma caracterização sob condições desnaturante (SDS-PAGE) além de caracterizar a pureza das enzimas, também nos permitiu estimar suas massas moleculares em torno de $77 \mathrm{kDa}$ para glucoamilase, $59 \mathrm{kDa}$ para $\alpha$-glucosidase I e $55 \mathrm{kDa}$ para $\alpha$-glucosidase II. Massas moleculares semelhantes, $76 \mathrm{kDa}$ para glucoamilase, $56 \mathrm{kDa}$ para $\alpha$-glucosidase I e $52 \mathrm{kDa}$ para $\alpha$-glucosidase II foram determinadas eluindo as mesmas enzimas em cromatografia de filtração em gel. De acordo com NOROUZIAN et al 2006, a massa molecular de glucoamilases de vários fungos encontram-se geralmente entre 48 e 90 kDa, com pouca exceções, tal como aquela produzida por A. niger que teve sua massa molecular estimada em $125 \mathrm{kDa}$ (SURESH et al., 1999) e as $\alpha$-glucosidases de Mortierella allicea e 
Chaetomium thermophilum var. coprophilum de 92 e 48 kDa (TANAKA et al., 2002, GIANNESI et al., 2006), respectivamente.

O conteúdo de carboidratos foi estimado em $15 \%$ para glucoamilase. Este dado é consistente com os encontrados na literatura, uma vez que a maioria das glucoamilases fúngicas tem apresentado conteúdos de carboidratos entre 10 e $20 \%$, com poucas exceções, tal como aquele determinado para glucoamilase de Nerospora crassa em 5,1\% (SPINELLI et al., 1996). A $\alpha$-glucosidase I e $\alpha$-glucosidase II apresentaram conteúdos de carboidratos de 4,0 e $29 \%$, respectivamente. O pI determinado para glucoamilase de A. niveus foi de 3,8, e esse mesmo valor foi determinado para glucoamilase de Thermomyces lanuginosus (THORSEN et al., 2006). O pI determinado para $\alpha$-glucosidase I foi de 6,6 enquanto que o da $\alpha$-glucosidase II foi de 6,9. Similar pI foi determinado para $\alpha$-glucosidase de Mortierella alliceae em 6,3 (TANAKA et al., 2002), já uma $\alpha$-glucosidase de Paecilomyces lilacinus apresentou um pI de 9.1 (KOBAYASHI et al., 2003).

Glucoamilases fúngicas são usualmente mais ativas em pHs ácidos. O pH ótimo de atividade para a glucoamilase de A. niveus foi de 5,0 e 5,5. Glucoamilases produzidas por linhagens de A. terreus apresentaram pHs ótimos de atividade 4,0 e 5,0 (ALI \& HOSSAIN, 1991, GHOSH et al., 1991), respectivamente. A atividade enzimática foi ácida e alcalina tolerante, mantendo-se estável por 2 horas em faixa de $\mathrm{pH}$ de 4,0 a 9,5. Esse dado é interessante quando se visa a aplicação dessas enzimas em processos que envolvem variações de $\mathrm{pH}$. A temperatura ótima de atividade apresentada para a glucoamilase de A. niveus foi de $65^{\circ} \mathrm{C}$. Essa temperatura é superior a aquelas apresentadas para glucoamilases de A. terreus que foi de $60^{\circ} \mathrm{C}$ e Aspergillus sp AS-2 de $50^{\circ} \mathrm{C}$ (GHOSH et al., 1991 e SONI et al., 2003), respectivamente. A enzima manteve 50\% de capacidade hidrolítica depois de 360 minutos a $60^{\circ} \mathrm{C}$. Esse resultado é interessante, pois reforça o potencial para a aplicação dessa enzima em processos que exigem temperaturas elevadas. $\mathrm{O} \mathrm{pH}$ ótimo para a atividade tanto $\alpha$-glucosidase 
I quanto da $\alpha$-glucosidase II foi de 6,0. Muitas $\alpha$-glucosidases purificadas de diversas fontes exibem pHs ótimos de atividade que variam de 4,5 a 7,0 (YAMASAKI et al., 1973, OGUMA et al., 1992, FRANDSEN et al., 1998, GIANNESI et al., 2006). A atividade enzimática das duas enzimas foi também ácido e alcalino tolerante, mantendo-se estáveis por 2 horas em faixa de $\mathrm{pH}$ de 3,0 a 8,5 para $\alpha$-glucosidase I e 4,0 a 8,8 para $\alpha$-glucosidase II. As duas $\alpha$ glucosidases apresentaram temperatura ótima de atividade de $65^{\circ} \mathrm{C}$. Entre as $\alpha$-glucosidases fúngicas a temperatura ótima é variável, estando entre 35 e $65^{\circ} \mathrm{C}$ (KOBAYASHI et al., 2003, TANAKA et al., 2002, YAMAMOTO et al., 2004, OKUYAMA et al., 2005). As enzimas apresentaram boa estabilidade, mantendo a $\alpha$-glucosidase I $100 \%$ depois de 1 hora a $60^{\circ} \mathrm{C}$ e a a-glucosidase II 3 horas nessa mesma temperatura.

A glucoamilase de A. niveus mostrou uma pequena ativação pela maioria dos íons testados, em concentrações de 0,1mM. Não foi observada ativação significativa na concentração de $10 \mathrm{mM}$. Um dado curioso e intrigante observado neste experimento foi a pequena ativação apresentada pela enzima na presença dos íons metálicos mercúrio e chumbo na concentração de 1,0 Mm, e a pouca inibição apresentada por ambos na concentração de 10 mM. Fortes ou totais inibições têm sido mostradas na literatura na presença desses íons. Seria necessário avaliar se ocorre ativação quando outros sais, tanto de mercúrio quanto de chumbo estão no meio. A presença desses íons poderia estar alterando algumas características do meio, tal como $\mathrm{pH}$, o que provavelmente mudaria a conformação do sítio catalítico da enzima, o que facilitaria o ataque ao substrato. Seria interessante observar se essa ativação é reversível ou não, bem como avaliar o efeito desses íons sobre as constantes cinéticas da enzima, e também analisar o comportamento da hidrólise enzimática na presença de um inibidor competitivo para ambos os íons. Uma significativa ativação da $\alpha$-glucosidase I ocorreu na presença compostos $\mathrm{MnCl}_{2} .4 \mathrm{H}_{2} \mathrm{O}, \mathrm{NaH}_{2} \mathrm{PO}_{4} \mathrm{H}_{2} \mathrm{O}, \mathrm{ZnCl}_{2}$ e $\beta$-mercaptoetanol na concentração de $1 \mathrm{mM}$. A atividade de $\alpha$-glucosidas II não sofreu alteração significativa com a presença dos íons. Os íons 
metálicos $\mathrm{Hg}^{2+}, \mathrm{Ag}^{+2}$ e $\mathrm{Al}^{+3}$ inibiram completamente a atividade de $\alpha$-glucosidase de Chaetomium thermophilum var. coprophilum (GIANNESI et al., 2006).

A avaliação do efeito da adição de solventes orgânicos sobre a atividade das enzimas purificadas de A. niveus mostrou que as enzimas foram estáveis na presença de alguns deles. A glucoamilase foi estável na presença de metanol, tolueno, benzeno, acetona e hexano, em uma concentração de $10 \%$ no meio reacional. A $\alpha$-glucosidase I foi estável na presença de tolueno, benzeno e hexano na concentração de $10 \%$. Na concentração de $5 \%$ apenas os solventes álcool n-butílico, formol e acetona inibiram a atividade da enzima. A $\alpha$-glucosidase II apresentou estabilidade semelhante, permanecendo estável na presença de quase todos os solventes a $5 \%$. Na concentração de $10 \%$ foi estável ao benzeno e acetona. Esses resultados reforçam ainda mais o potencial dessa enzima para futuras aplicações em processos industriais, os quais necessitam de enzimas mais estáveis.

A glucoamilase de A. niveus mostrou excelente capacidade para hidrolisar diferentes substratos. O substrato mais susceptível ao ataque das enzimas foi o amido Sigma. A enzima também mostrou boa capacidade para hidrolisar glicogênio, amilopectina, maltotriose e maltose. A capacidade de hidrolise a amido de cadeias longas e de glicogênio, nos permite inferir que a enzima em questão é uma glucoamilase, já a incapacidade de degradar $\alpha$-PNPG e sacarose descarta a possibilidade de a enzima ser uma $\alpha$-glicosidade, uma vez que esses substratos são específicos para a ação dessas enzimas.

A $\alpha$-glucosidase I hidrolisou preferencialmente glicogenio, maltopentaose, maltotriose, amido solúvel, amilopectina, amilose, maltotetraose e maltose. A enzima também hidrolisou, embora com pouca eficiência os substratos isomaltose e maltooligossacarídeo G10. A $\alpha$ glucosidase II hidrolisou preferencialmente maltopentaose e glicogênio. A enzima também hidrolisou com eficiência amido solúvel, maltooligossacarídeo G10, $\alpha$-PNPG, maltotetraose, 
amilose e amilopectina. A capacidade de hidrolisar eficientemente a maioria dos substratos testados, somada as demais características apresentadas por essa enzima reforça a importância para aplicações em processos biotecnológicos.

A ação de duas ou mais enzimas atuando em conjunto em um determinado organismo ou processo, gerando aumento na produção de um determinado produto de interesse, maior que a soma dos produtos gerados pelas enzimas individualmente, recebe o nome de efeito sinergístico ou sinergia. Foi evidenciado claramente uma sinergia quando se fez a mistura das amilases de A. niveus na hidrólise do amido solúvel a 5\%. Considerando que, $100 \%$ de formação do produto equivalem à somatória da ação de cada enzima atuando separadamente, percebe-se um aumento de $62 \%$ quando as 3 enzimas estão envolvidas no processo, $32 \%$ quando há mistura de $\alpha$-glucosidase I e glucoamilase, $34 \%$ quando há mistura de $\alpha$ glucosidase I e $\alpha$-glucosidase II e $18 \%$ quando se mistura $\alpha$-glucosidase II e glucoamilase. Sabe-se que as $\alpha$-amilases atuam dextrinizando as cadeias de amido facilitando ação das glucoamilases gerando aumento na produtividade (GUZMÁN-MALDONADO \& PAREDESLOPEZ, 1995), desse modo, a $\alpha$-glucosidase I por ser uma enzima dextrinizante facilita a ação da glucoamilase e também da $\alpha$-glucosidase II uma vez que ambas são enzimas sacarificantes. O pequeno aumento na formação do produto quando se usou $\alpha$-glucosidase II e glucoamilase, pode ser explicado pelo fato de as enzimas atuarem de forma diferente sobre a molécula de amido. Essa diferença no modo de ação das enzimas sobre o substrato, pode ter criado melhores condições para ambas as enzimas proporcionando melhor rendimento. Cabe aqui ressaltar a importância da produção das três enzimas para o microrganismo, o que garante um maior poder de exploração do ambiente, tornando-o mais competitivo junto aos demais organismos. 
Os parâmetros cinéticos das amilases de A. niveus foram analisados utilizando os substratos pelos quais as enzimas apresentaram maior afinidade. A glucoamilase apresentou grande afinidade para o amido solúvel e o seu Km e Vmax foi de 0,32 mg/mL e $237 \mathrm{U} / \mathrm{mg}$ de proteína, respectivamente. A $\alpha$-glucosidase I apresentou grande afinidade com amido solúvel, glicogênio e maltose. A maior eficiência catalítica foi verificada na presença de glicogênio, seguido de amido solúvel e maltose. A $\alpha$-glucosidase II já apresentou atividade sobre vários substratos e os valores de $\mathrm{K}_{\text {cat }} / \mathrm{K}_{\mathrm{m}}$ obtidos mostraram maior preferência dessa enzima pelo glicogênio, seguido de amido solúvel, amilopectina, maltose e $\alpha$ - $\rho$ NPG.

Tanto a glucoamilase quanto às $\alpha$-glucosidases I e II apresentaram um espectro de CD caracterizados por dois mínimos pronunciados em torno de 222 e 207 nm, e um máximo positivo em torno de $196 \mathrm{~nm}$. Essas bandas são características de proteínas contendo estruturas em $\alpha$-hélice. Outros estudos com análise de CD serão realizados com essas enzimas a fim de se obter informações mais conclusivas a respeito das estruturas secundárias. Estudo de desnaturação térmica, associado à desnaturação das estruturas secundaria de glucoamilase, $\alpha$ glucosidase I e $\alpha$-glucosidase II, poderão ser feitos para que se possa entender melhor o comportamento estrutural dessas proteínas mediante desnaturação térmica, uma vez que essas enzimas apresentaram uma boa estabilidade à temperaturas elevadas.

A análise do sequenciamento da glucoamilase (SPRAL) mostrou haver similaridade entre essa enzima e as glucoamilases de A. terreus, A. niger, A. ficcum, A. awamori, A. kawachi e A. shirousami. A homologia apresentada bem como os dados obtidos para especificidade ao substrato, e a natureza do produto de hidrólise liberado a partir do amido solúvel nos permitiu concluir que essa enzima é uma glucoamilase (EC 3.2.1.3 1,4- $\alpha$-Dglucano glucohidrolase). O seqüenciamento de peptídeos da $\alpha$-glucosidase I e II de A. niveus obtidos por espectrometria de massa revelaram similaridade dessas enzimas com uma $\alpha$ - 
glucosidase de A. fumigatus. Esses dados somados aqueles obtidos para especificidade ao substrato e capacidade de hidrolisar o $\alpha$-pNPG revelou o caráter dessas enzimas como $\alpha$ glucosidases (EC 3.2.1.20 $\alpha$-D-glucosídeo glucohidrolase).

$\mathrm{O}$ efeito da $\mathrm{N}$-glicanas sobre as enzimas amilolíticas de A. niveus foi verificado mediante adição de $30 \mu \mathrm{g} / \mathrm{mL}$ de tunicamicina no meio de cultivo, contendo amido como fonte de carbono. A quantidade semelhante das massas miceliais do fungo formadas nos meios de cultivo com presença e ausência de tunicamicina, bem como as concentrações similares de proteínas extracelulares secretadas nos permitiu inferir que a droga não interferiu no crescimento do microrganismo. As três enzimas amilolíticas proveniente de meio de cultivo tratado com tunicamicina foram purificadas e diferentes perfis cromatográficos foram observados se comparados àqueles obtidos com meios de cultivos não tratados com a tunicamicina. A glucoamilase e a $\alpha$-glucosidase I apresentou baixa atividade o que nos leva a crer que houve perda da especificidade dessas enzimas pelo substrato em função da remoção das N-glicanas, que foi claramente evidenciado para a glucoamilase em SDS-PAGE.

A $\alpha$-glucosidase II não perdeu especificidade pelo substrato e manteve as características apresentadas pela enzima nativa, como $\mathrm{pH}$ ótimo de atividade, estabilidade ao $\mathrm{pH}$, temperatura ótima de atividade e constantes cinéticas, exceto estabilidade a temperatura, onde foi possível verificar uma diferença significativa entre as estabilidades das enzimas nativas e desglicosiladas. De fato, a glucoamilase e $\alpha$-glucosidase I possuem em suas estruturas um numero maior de possíveis sítios de ligação a $\mathrm{N}$-glicanas, dado este que foi confirmado por análise de bioinformática. A glucoamilase apresentou vários possíveis sítios de ligação a $\mathrm{N}$-glicanas, enquanto a $\alpha$-glucosidase II apresentou apenas 2 possíveis sítios, que foram confirmados mediante eluição das proteínas nativas e desglicosiladas em Concanavalina A. A $\alpha$-glucosidase II nativa aderiu a resina enquanto que a $\alpha$-glucosidase II desglicosilada 
não apresentou essa mesma afinidade. Por outro lado, a análise de bioinformática mostrou que a $\alpha$-glucosidase II possui um maior número de prováveis sítios de ligação a O-glicanas, e que nesse caso parece estar mais envolvido com as características físico-químicas da enzima. A possível presença de sítios para ligação de O-glicanas na $\alpha$-glucosidase II foi comprovada mediante adsorção da enzima em Jacalina, que constitui uma resina especifica para interações com proteínas O-glicosiladas.

Em geral enzimas em solução não apresentam uma boa estabilidade a temperaturas elevadas e ao tempo de armazenamento. Geralmente enzimas imobilizadas conseguem permanecer estáveis por períodos maiores sobre temperaturas elevadas e por consideráveis períodos de armazenamento. $\mathrm{O}$ aumento na estabilidade de derivados enzimáticos juntamente com a possibilidade de uso dos catalisadores imobilizados por mais de um ciclo, tem motivado muitas pesquisas com imobilização de enzimas com aplicações biotecnológicas. A glucoamilase e a $\alpha$-glucosidase II foram submetidas a ensaios de imobilização, em suportes com interação iônica e por ligação covalente. Os suportes sólidos e insolúveis utilizados para a imobilização das enzimas por troca iônica foram, Glioxil-PEI, Glioxil-MANAE, Sepharose Q e DEAE-Sephacel, já os suportes sólidos utilizados para imobilização por ligação covalente foram, agorase ativada com brometo de cianogênio $(\mathrm{BrCN})$, que estabelece ligação unipontual com a enzima e a Glioxil agarose a pH 10,5, estabelecendo ligações do tipo multipontual. A estabilidade dos derivados imobilizados em $\mathrm{BrCN}$ foram maiores que aqueles apresentadas para as enzimas solúveis e também para os derivados imobilizados em suportes trocadores iônicos. A estabilidade dos derivados obtidos através de ligações covalentes muitipontuais foi maior que aquela apresentada para os derivados imobilizados em $\mathrm{BrCN}$ e também para aqueles imobilizados com suportes trocadores iônicos. Esse resultado de fato era esperado 
uma vez que derivados formados através de ligações covalentes são menos susceptíveis a desnaturação térmica que aqueles formados por interação do tipo troca iônica.

$\mathrm{Na}$ tentativa de melhorar a estabilidade dos derivados foram adicionados trealose e dextrano $70 \mathrm{kDa}$ com os derivados de glucoamilase, e trealose com os derivados de $\alpha$ glucosidase II. Os Efeitos da adição de trealose junto aos derivados de glucoamilase foram variados. A concentração de $20 \%$ foi a melhor para os derivados Sepharose Q e GlioxilMANAE, já para os derivados DEAE-Sephacel e BrCN as melhores concentrações foram de 50 e $30 \%$, respectivamente. Com relação a adição de dextrano observou-se que a concentração de $20 \%$ foi a que melhor atuou em todos os derivados de glucoamilase. Para os derivados de $\alpha$-glucosidase II não foi possível verificar um efeito aditivo do dextrano $70 \mathrm{kDa}$, pois a enzima apresentou uma extrema afinidade por esse açúcar, que foi hidrolisado com muita facilidade. A trealose atuando como aditivo sobre os derivados de $\alpha$-glucosidase II proporcionou um aumento muito significativo na estabilidade. A concentração de $20 \%$ foi a melhor em todos os casos.

Com base nos resultados apresentados conclui-se que Aspergillus niveus é um excelente produtor de amilases com características desejáveis para aplicação em processos biotecnológicos. As amilases secretadas em meio de cultivo com amido solúvel foram caracterizadas como uma glucoamilase típica e $2 \alpha$-glucosidases com propriedades distintas das demais descritas na literatura. A $\alpha$-glucosidase II hidrolisa preferencialmente glicogênio e amido, a maltooligossacarídeos de cadeias curtas e $\alpha$-pNPG. A $\alpha$-glucosidase I apresentou características semelhantes a $\alpha$-glucosidase II, e também atua sobre a molécula de amido liberando glicose, maltose, maltotriose e maltotetraose. Tais características nos permite designar essas enzimas como novas $\alpha$-glucosidases. Com relação as $\mathrm{N}$ e O-glicanas ficou evidente que asses açucares são de extrema importância para as enzimas amilolíticas de $A$. 
niveus. A glucoamilase e a $\alpha$-glucosidase I apresentaram ser mais $\mathrm{N}$-glicosiladas que a $\alpha$ glicosidase II, por apresentarem características funcionais distintas quando sintetizadas mediante tratamento com tunicamicina. A estabilidade apresentada pelos derivados formados por ligações covalentes multipontuais foi maior que aquela evidenciada para os derivados formados por ligações unipontuais e por interação iônica. O uso da trealose como aditivo aumentou significativamente a estabilidade de todos os derivados, por exercer sobre esses um efeito protetor. 


\section{VI- REFERENCIAS BIBLIOGRÁFICAS}

ADAMS, P. R. Mycelial amylase activities of thermophilic species of Rhizomucor, Humicola and Papulaspora. Mycopatologia, v. 112, p.35-37, 1990.

ALI, S.; HOSSAIN, Z. Characteristics for glucoamylase from Aspergillus terreus. J. App. Bacteriol., v.71, p. 144-146, 1991.

ANGAYARKANNI, J.; PALANISWAMY, M.; PRADEEP, B. V.; SWAMINATHAN, K. Biochemical substitution of fungal xylanases for prebleaching of hardwood kraft pulp. Afr. J. Biotechnol. v. 5, p. 921-929, 2006.

ANGAYARKANNI, J.; PALANISWAMY, M.; MURUGESAN, S.; SWAMINATHAN, K. Improvement of Tea Leaves Fermentation with Aspergillus spp. Pectinase. J. Biosc. And Bioeng. v. 94, p. 299-303, 2002.

ANTRANIKIAN, G.; RUDIGER, A.; CANGANELlA, F.; KLINGEBERG, M.; SUNNA, A. Biodegradation of polymers at temperatures up to 130-degrees-c. J. Macromol. Sci. Pure. Appl. Chem. v.32, p. 661-669,1995.

ANTRIM, R. L.; AUTERINEN, A. L. A new regenerable immobilized glucose isomerase. Stärke. v. 38, p. 132-137, 1986.

APWEILER, R.; HERMJAKOB, H.; SHARON, N. On the frequency of protein glycosylation, as deduced from analysis of the SWISS-PROT database. Biochim Biophys Acta. v. 1473, p. 4-8, 1999.

ARNESEN S.; HAVN ERIKSEN S.; OLSEN J.; JENSEN, B. Increased production of $\alpha$-amylase from Thermomyces lanuginosus by the addition of Tween 80 - Evolutionary implications. Enz. Microb. Technol. v. 4, p. 249-252, 1988.

BAUSE, E. Structural requirements of $N$-glycosylation of proteins. Studies with proline peptides as conformational probes. Biochem J. v. 209, p. 331-336, 1983.

BENASSI, V. M. Estudo de amilases produzidas pelo fungo termotolerante Aspergillus phoenicis. Monografia apresentada ao Departamento de Biologia da FFCLRP-USP, 2006.

BENNAMOUN, L.; MERAIHI, Z.; DAKHMOUCHE, S. Utilisation de la planification expérimentale pour 1'optimisation de la production de 1' $\alpha$-amylase par Aspergillus oryzae Ahlburg (Cohen) 1042.72 cultivé sur milieu à base de déchets d'oranges. J. Food Engineering., v. 64, p. 257-264, 2004.

BERGMEYER, H. U.; BERNT, E. Methods of Enzymatic Analisis. Edited by H. Bergmeyer. Verla-Chimie-Academic Press, New York, v. 3, p. 1205-1215, 1974.

BLANCO, R. M.; CALVETE, J. J.; GUISÁN, J. M. Immobilization-stabilization of enzymes; variables that control the intensity of the trypsin (amine)-agarose (aldehyde) multipoint attachment. Enz. Microbial Technol. v. 11, p. 353-359, 1989. 
BUCHHOLZ, K. Characterization of immobilized biocatalysts; in Dechema Monograph, (Weinheim: VCH). v. 84, 1979.

BUCHHOLZ, K.; KASCHE, V.; BORNSCHEUER, U. T. Biocatalysts and Enzyme Technology (Weinheim: Wiley-VCH), 2005.

BUSCH, J. E.; STUTZENBERGER, F. J. Amylolytic activity of Thermomonospora fusca. World J. Microbiol Biotechnol., v.13, p. 637-642, 1997.

CANTARELLI, C. Use oj inmobilized yeasts in wine fermentation. Journal of food science. 3, 320, 1989.

CARLSEN, M.; NIELSEN, J.; VILLADSEN, J.; Growth and $\alpha$-amylase production by Aspergillus oryzae during continuous cultivations. J. Biotechnol, v. 45, p. 81-93, 1996.

CHEN, W. D.; TONG, X. D.; DONG, X. Y.; SUN, Y. Expanded bed adsorption of protein with DEAE spherodex M. Biotechnology Progress. v.19, p. 880-886, 2003.

CRUZ, R.; SOUSA, E. L.; HOFFMANM, E. H. E.; BELLINI, M. Z. B.; CRUZ, V. D; VIEIRA, C. R. Relationship between carbon source, production and patter action of $\alpha$-amylase from Rhizopus sp. Rev. Microbiol. v. 28, p. 101-105, 1997.

CUI, R.; OATES, C. G. The affect of amylose-lipid complex formation on enzyme susceptibility of sago starch. Food Chemistry. v. 65, p. 417-425, 1999.

DAVIS, B. J. Disc eletroforesis II. Methods and application to human serum proteins. Ann. N. Y. Ascad. Sci. v. 121, p. 404-427, 1964.

DE MOT, R.; ANDRIES, K.; VERACHTERT, H. Comparative study of starch degradation and amylase production by Ascomycete yeast species. Appl. Microbiol. v. 5, p. 106-118, 1984.

DREHER, M. L.; BERRY, J. W.; DREHER, C. J. Starch digestibility of foods. A nutritional perspective. Critical. Revew in food science and nutrition. v. 20, p. 47-71, 1984.

DUBOIS, M.; GILLES, K. A.; HAMILTON, J. K.; REBERS, P. A.; SMITH, F. Colorimetric method for determination of sugars and related substances. Anal. Chem. v. 28, p. 350-356, 1956.

ELLAIAH, P.; ADINARAYANA, K.; BHAVANI, Y.; PADMAJA, P.; SRINIVASULU, B. Optimization of process parameters for glucoamylase production under solid state fermentation by a newly isolated Aspergillus species. Process Biochem. v. 38, p. 615-620, 2002.

ESFAHANIBOLANDBALAIE, Z.; ROSTAMI, K.; MIRDAMADI, S. S. Some studies of alphaamylase production using Aspergillus oryzae. Pak. J. Biol. Sci. v. 11, p. 2553-2559, 2008.

FABER, K. Biotransformations in Organic Chemistry (New York: Springer), 1996. 
FENEMA, O. R. Introdución a la Ciência de los Alimentos. Barcelona. Ed. Reveré, S. A., v.1, 445 pp, 1985.

FERNÁNDEZ-LAFUENTE, R.; RODRÍGUEZ, V.; MATEO, C.; PENZOL, G.; HERNÁNDEZJUSTIZ, O.; IRAZOQUI, G.; VILLARINO, A.; OVSEJEVI, K.; BATISTA, F.; GUISÁN, J. M. Stabilization of multimeric enzymes via immobilization and post-immobilization techniques. Journal Mol. Catalysis - B Enzymatic. v. 7, p. 181-189, 1999a.

FIEDLER K; SIMONS K. The role of N-glycans in the secretory pathway. Cell. v. 81, p. 309-312, 1995.

FRANCIS, F.; SABU, A.; NAMPOOTHIRI, K.; RAMACHANDRAN, S.; GHOSH, S.; SZAKACS, G.; PANDEY, A. Use of response surface methodology for optimizing process parameters for the production of $\alpha$-amylase by Aspergillus oryzae. Biochem. Engin. J., v.15, p.107-115, 2003.

FRANDSEN, T. P.; SVENSSON, B. Plant $\alpha$-glucosidaseof the glycoside hydrolase famaly 31. Molecular properties, substrate specifity, reaction mechanism, and comparison with family members of different origin. Plant Mol. Biol. v. 27, p. 1-13, 1998.

GASTEIGER, E.; HOOGLAND, C.; GATTIKER, A.; DUVAUD, S.; WILKINS, M. R.; APPEL, R. D.; BAIROCH, A. Protein identification and analysis tools on the ExPAS yserver. (In) John M. Walker (ed): The Proteomics Protocols Handbook, Humana Press, pp. 571-607, 2005.

GHOSH, A; CHATTERJEE, B.; DAS, A. Purification and characterization of glucoamylases of Aspergillus terreus NA-170 mutant. J. Appl. Bacteriol., v.71, p.162-169,1991.

GIANNESI, G. C.; POLIZELI, M. L. T. M.; TERENZI, H. F.; JORGE, J. A. A novel $\alpha$ glucosidase from Chaetomium thermophilum var. coprophilum that converts maltose into trehalose: purification and partial characterization of the enzyme. Process Biochem. v. 41, p. 1729-1735, 2006.

GLAZER, A. N.; NIKAIDO, H. Microbiol Biotechnology, W.H. Freeman and Company, New York,. p. 662, 1995.

GOTO, C. E.; BARBOSA, E. P.; KISTNER, L. C. L.; GANDA, R. F.; ARRIAS, V. L.; PERALTA, R. M. Production of amylases by Aspergillus fumigatus. Rev. Microbiol., v. 29, p. 99103, 1998.

GOTO M. (2007). Protein O-Glycosylation in Fungi: Diverse Structures and Multiple Functions. Biosci. Biotechnol. Biochem., 71(6): 1415-1427.

GOUKA, R. J.; PUNT, P. J.; VAN DEN HONDEL, C. A. M. J. J. Efficient production of secreted proteins by Aspergillus: progress, limitations and prospects. Appl. Microbiol. Biotechnol. v. 47, p. $1-11,1997$. 
GUISÁN, J. M.; ALVARO, G.; FERNÁNDEZ-LAFUENTE, R.; ROSELL, C. M.; GARCIA, J. L.; TAGLIANI, A. Stabilization of heterodimeric enzyme by multipoint covalent immobilization: Penicillin G acylase from Kluyvera citrophila. Biotechnology and Bioengineering. v. 42, p. 455464, 1993.

GUPTA, R.; GIGRAS, P.; MOHAPATRA, H.; KUMAR, V. G.; CHAUHAN, B. Microbiol $\alpha-$ amylases: a biotecnological perspective. Process Biochem, v. 38, p. 1599-1616, 2003.

GUZMÁN-MALDONADO, H.; PAREDES-LÓPEZ, O. Amylolytic enzymes and products derived from starch: A review. Crit. Rev. Food Sc. Nut, v. 35, p. 373-403, 1995.

HANES, C. S. The effect of starch concentration upon the velocity of hydrolysis by the amylase of germinated barley. Biochem. J. v. 26, p. 1406-1421, 1932.

HAKI, D. G.; RAKSHIT, K. S. Developments in industrially important thermostable enzymes: Bioresour. Technol. v. 89, p. 17-34, 2003.

HELENIUS, A; AEBI, M. Roles of N-linked glycans in the endoplasmatic reticulum. Ann. Rev. Biochem. v. 73, p. 1019-1049, 2004.

HUBER, K. C.; BEMILLER, J. N. Visualization of channels and cavities of corn and sorghum starch granules. Cereals chemistry. v. 74, p. 537-541, 1997.

IMPERIALI, B.; RICKERT, K. W. Conformational implications of asparagine-linked glycosylation. Proc. Natl. Acad. Sci. v. 92, p. 97-101, 1995.

IWASHITA, K. Recent studies of protein secretion by filamentous fungi. J. Biosci. Bioeng. v. 94, p. 530-535, 2002.

JENSON, B.; OLSEN, J.; ALLERMANN, K. Purification of extracellular amylolytic enzymes form the thermofilic fungus thermomyces lanuginosus. Can J Microbiol, v. 34, p. 218-223, 1988.

JIN, B.; LEEUWEN, H. J.; PATEL, B.; DOELLE, H. W.; YU, Q. Production of fungal protein and glucoamilase by Rhizopus oligosporus from starch processing wasterwater. Process Biochem., v. 34, p. 59-65, 1999.

JULENIUS K.; MOLGAARD A.; GUPTA R.; BRUNAK S. Prediction, conservation analysis and structural characterization of mammalian mucin-type O-glycosylation sites. Glycobiology. v. 15, p. 153-164, 2005.

KAUR, P.; SATYANARAYANA, T. Production and saccharification by a thermostable and neutral glucoamylase of a thermophilic mould Thermomucor indicae-seudaticae. J. Microbiol. Biotechnol.. v. 20, p. 419-425, 2004.

KENNEDY, J. F.; MELO, E. H. M.; JUMEL, K. Immobilized enzymes y cells. Chemical Engineering Progress. v. 86, p. 81-89, 1990. 
KHANNA, P.; SUNDARI, S. S.; KUMAR, N. J. Production, isolation and partial purification of xylanase from Aspergillus sp. World J. Microbiol. Biotecnol., v.11, p. 242-243, 1995.

KILIKIAN, B. V. Production of glucoamylase by fed-batch culture of Aspergillus awamori NRRL 3112. Rev. Microbiol., v. 27, p. 10-12, 1996.

KLIBANOV, A. M. Enzymes: Nature's chemical machines. Technology review. v. 86, p. 40-48, 1983.

KOBAYASHI, F.; SAWADA, T.; NAKAMURA, Y.; OHNAGA, M.; GODLIVING, M.; USHIYAMA, T. Sacaharification and alcohol fermentation in starch solution of stream-explodet potato. Appl. Bioch. Biotechnol., v. 69, p. 177-189, 1998.

KOBAYASHI, I.; TOKUDA, M.; HASHIMOTO, H.; KONDA, T.; NAKANO, H.; KITAHATA, S. Purification and characterizaton of a new type of $\alpha$-glucosidase from Paecilomyces lilacinus that has transglucosylation activity to produce $\alpha-1,3-$ and $\alpha$-1,2-linked oligosaccharides. Biosci. Biotechnol. Biochem. v. 67, p. 29-35, 2003.

KOCHER, G. S; KAUR, P.; GREWAL, H. S. Production of $\alpha$-amylase by Aspergillus niger using wheat bran in submerged and solid state fermentations. Indian J. Microbiol. v. 43, p. 143$145,2003$.

KOTTWITZ, B.; UPADEK, H.; CARRER, G. Applications and benefits of enzymes in detergents. Chim Ogg. v. 12, p. 21-24, 1995.

KUMAR, R. K.; VENKATESH, S. K.; KUMAR, U. S. Evidence that cleavage of the precursor enzyme by autocatalysis caused secretion of multiple amylases by Aspergillus niger. FEBS Letters. v. 557, p. 239-242, 2004.

YAMAMOTO, T.; UNNO, T.; WATANABE, Y.; YAMAMOTO, M.; OKUYAMA, M.; MORI, H.; CHIBA, S.; KIMURA, A. Purification and characterization of Acremonium implicatum $\alpha-$ glucosidase having regioselectivity for $\alpha-1,3$-glucosidic linkage. BBActa. v. 1700, p. 189-198, 2004.

YAMASAKI, Y.; MIYAKE, T.; SUZUKI, Y. Properties of crystalline $\alpha$-glucosidase from Mucor javanicus. Agric. Biol. Chem. v. 37, p. 251-259, 1973.

LAEMMLI, U. K. Cleavage of structural proteins during the assembly of head of bacteriophage T4. Nature. v. 227, p. 680-685, 1970.

LASZLO, H.; BASSO, L. M.; COELHO, C. M. L. Química de Alimentos, Nobel, São Paulo, p.98, 1986. 
LECKBAND, D.; LANGER, R. An approach for the stable immobilization of proteins. Biotechnology and Bioengineering. v. 37, p. 227-237, 1991.

LEHNINGER, A. C.; NILSON, D. L.; COX, M. M. Princípios de Bioquímica. Worth publishers, $4^{\mathrm{a}}$ ed., 2005.

LEONE, F. A.; BARANAUSKAS, J. A.; CIANCAGLINI, P. Enzyplot: a microcomputer assistant program for teaching enzyme kinectis. Biochem. Educ. v. 23, p. 35-37, 1995.

LETUNIC, I.; DOERKS, T.; BORK, P. SMART 6: recent updates and new developments. Nucleic Acids Res. v. 37, p. 229-232, 2009.

LOWRY, O. H.; ROSEBROUGH, N. I.; FARR, A. L.; RANDALL, R. J. Protein measurement with the folin phenolreagent. J. Biol. Chem. v. 193, p. 265-175, 1951.

LYDDIATT, A. Process chromatography: Current constraints and future options for the adsorptive recovery of bioproducts. Current Opinion in Biotechnology. v. 13, p. 95-103, 2002.

MADIGAN, M. T.; MARTINKO, J. M.; PARKER, J. Brock Biology of Microorganisms. Prentice Hall. 10 $10^{\mathrm{a}}$ Ed., 2003.

MARÍN, D.; LINDE, D.; LOBATO, M. F. Purification and biochemical characterization of an $\alpha$ glucosidase from Xanthophyllomyces dendrorhus. Yeast. v. 23, p. 117-125, 2006.

MATEO, C.; ABIÁN, O.; FERNÁNDEZ-LAFUENTE, R.; GUISÁN, J. M. Reversible enzyme immobilization via a very strong y nondistorting ionic adsorption on support-polyethylenimine composites. Biotechnology and Bioengineering. v. 68, p. 98-105, $200 \mathrm{~b}$.

MICHELIN, M. Estudo da glucoamilase e da $\alpha$-amylase produzidas pelo fungo Paecilomyces variotii: purificação, caracterização bioquímica e relações filogenéticas. Dissertação (mestrado em Biologia Comparada)- FFCLRP-USP, P.49, 2005.

MICHELIN, M.; RULLER, R.; WARD, R. J., MORAES, L. A.; JORGE J. A.; TERENZI, H. F.; POLIZELI, M. L. T. M. Purification and biochemical characterization of a thermostable extracellular glucoamylase produced by the thermotolerant fungus Paecilomyces variotii. J. Ind. Microbiol. Biotechnol. v. 35, P. 17-25, 2007.

MILLER, G. L. Use of dinitrosalicylic acid reagent for determination of reducing sugars. Anal. Chem., v.31, p.426-428, 1959.

MISHRA, R.; MAHESHWARI, R. Amylases of thermophilic fungus Thermomyces lanuginosus. Their purification, properties, action on starch and response to heat. J. Biosc.. v. 21, p. 653-672, 1996. 
MOHAPATRA, B. R.; BANERJEE, U. C.; BAPUJI, M. Characterization of fungal amylase from Mucor sp. associated with the marine sponge Spirastrella sp. J. Biotechnol.. v. 60, p. 113-117, 1998.

MOLINARI, M.; HELENIUS, A. Glycoproteins form mixed disulphides with oxidoreductases during folding in living cells. Nature. v. 402, p. 90-93, 2000.

MOLLER, K; SHARIF, M. Z; OLSSON, L. Production of fungal $\alpha$-amylase by Saccharomyces kluyveri in glucose-limited cultivations. J. Biotechnol. v. 111, p. 311-318, 2004.

MOREIRA, F. G.; LIMA, F. A.; PEDRINHO, S. R. F.; LENARTOVIEZ, V.; SOUZA, C. M. S.; PERALTA, R. M. Production of amylases by Aspergillus tamari. Rev. Microbiol., v. 30, p. 157$162,1999$.

NAHAS, E.; WALDERMARIN, M. M. Control of amylase production and growth characteristics of Aspergillus ochraceus. Revista Latino Americana de Microbiologia. v. 44, p. 5-10, 2002.

NEUHOFF, V.; AROLD, N.; TAUBE, D.; EHRHARDT, W. Improved staining of proteins in polyacrylamide gels including isoeletric focusing gels with clear background at nanogram sensitivity using Coomassie Brilhant Blue G-250 and R-250. Electrophoresis. v. 9(6), p. 255-262, 1988.

NGUYEN, D. G.; REZESSY-SZABÓ, J. M.; HOSCHKE, A. Optimisation of composition of media for the production of amylolytic enzymes by Thermomyces lanuginosus ATCC 34626. Food Technol. Biotechnol. v. 38, p. 229-234, 2000.

NGUYEN, Q. D.; REZESSY-SZABÓ, J. M.; CLAEYSSENS, M.; STALS, I.; HOSCHKE, Á. Purification and characterizatrion of amylolytic enzymes from thermophilic fungus Thermomyces lanuginosus strain ATCC 34626. Enz. Microbial. Tecnol. v. 31, p.345-352, 2002.

O'CONNOR, S. E.; IMPERIALI, B. Effect of $N$-linked glycosylation on glycopeptide and glycoprotein structure. Chem. Biol. v. 3, p. 643-649, 1996.

OGUMA, T.; MATSUI, H.; TANIDA, M.; TAKAO, S.; HONMA, M.; CHIBA, S. Purification and substrate specificity of a $\alpha$-glucosidase from Paecilomyces varioti AHU. Biosci. Biotechnol. Biochem. v. 56, p. 1906-1910, 1992.

O’FARREL, P. Z.; GOODMAN, H. M.; O’FARREL, P. H. Hight resolution two dimensional electrophoresis of basic as acidic proteins. Cell. v. 12, p. 1133-1142, 1977.

OKUYAMA, M.; TANIMOTO, Y.; ITO, T.; ANZAI, A.; MORI, H.; KIMURA A. Purification and characterization of the the hyper-glycosilated extrecellular $\alpha$-glucosidase from Schizosaccharomyces pombe. Enz. Microb. Technol. v. 37, p. 472-280, 2005. 
PANDEY, A.; NIGAM, P.; SOCCOL, C. R.; SOCCOL, V. T.; SINGH, D.; MOHAN, R. Advances in microbial amylases. Rev. Biotechnol. Appl. Biochem.. v. 31, p. 135-152, 2000.

PAPAGIANNI, M. Fungal morphology and metabolite production in submerged mycelial processes. Review. Biotechnol. Adv. v. 22, p. 189-259, 2004.

PEIXOTO, S. C.; JORGE, J. A.; TERENZI, H. F.; POLIZELI, M. L. T. M. Rhizopus microsporus var. rhizopodiformis: a thermotolerant fungus with potential for production of thermostable amylases. Int. Microbiol. v. 6, p. 269-273, 2003.

PEIXOTO-NOGUEIRA, S. C.; SANDRIM, V. C.; GUIMARÃES, L. H.; JORGE, J. A.; TERENZI, H. F.; POLIZELI, M. L. T. M. Evidence of thermostable amylolytic activity from Rhizopus microsporus var. rhizopodiformis using wheat bran and corncob as alternative carbon source. Bioprocess Biosyst Eng. v. 31, p. 329-334, 2008.

PRIETO, J. A.; BORT, B. R.; MARTINEZ, J.; RANDEZ-GIL, F.; BUESA, C.; SANZ, P. Purification and characterization of a new $\alpha$-amylase of intermediate thermal stability from the yeast Lipomyces kononenkoae. Biochem. Cell Biol. v. 73, p. 41-49, 1995.

RAIMBAULT, M. General and microbiological aspects of solid substrate fermentation. J. Biotechnol. v. 1, p. 175-188, 1998.

RAJOKA, M. I.; YASMIN. A.; LATIF. F. Kinetics of enhanced ethanol productivity using raw starch hydrolyzing glucoamilase from Aspergillus niger mutant produced in solid state fermentation. Appl. Microbiol.. v. 39, p. 13-18, 2004.

RAMACHADAN, S.; PATEL, A. K.; MADHAVAN, N.; FRANCIS, F.; NAGY, G. S.; PANDEY, A. Coconut oil cake potential raw material for the production of $\alpha$-amylase. Biors. Technology, $v$. 93, p. 169-174, 2004.

RIZZATTI, A. C. S.; JORGE, J. A.; TERENZI, H. F.; RECHIA, C. G. V., POLIZELI, M. L. T. M. Purification and properties of a thermostable extracellular $\beta$-D-xylosidase produced by thermotolerant Aspergillus phoenicis. J. Ind. Microbiol. Biotechnol, v.26, p.156-160, 2001.

RONASZEK, G.; NGUYEN, Q. D.; REZESSY-SZABO, J. M.; HOSCHKE, A.; BHAT, M. K. Screening the strains of thermofilic fungus Thermomyces lanuginosos for amylolytic activities. Acta Alimentaria, v. 29 (1), p. 71-79, 2000.

RUDD, P. M.; ELLIOTT, T.; CRESSWELL, P.; WILSON, I. A.; DWEK, R. A. Glycosylation and the Immune System. Science. v. 291, p. 2370-2376, 2001.

SKROPETA, D. The effect of individual $\mathrm{N}$-Glycans on enzyme activity. Bioorg. Med. Chem. v. 17(2), p. 2645-2653, 2009. 
SHIRAGA, S.; KAWAKAMI, M.; UEDA, M. Construction of combinatorial library of starchbinding domain of Rhizopus oryzae glucoamylase and screening of clones with enhanced activity by yeast display method. J. Mol. Catalysis B: Enz. v. 28, p. 229-234, 2004.

SILVA, T. M.; ATTILI-ANGEliS, D.; CARVAlHO, A. F. A.; DA SILVA, R.; GOMES, E. Production of sacharogenic and dextrinogenic amylases by Rhizomucor pusillus A 13.36. The Journal of Microbiology Korea. v. 43, p. 561-568, 2005.

SINGH, D.; DAHIYA, J. S; NIGAM, P. Simultaneous raw starch hydrolysis and ethanol fermentation by glucoamylase from Rhizocolonia solini and Saccharomyces cerevisae. J. Basic. Microbiol. v. 35, p. 117-121, 1995.

SKORUPA, P. N.; MORAES, L. M. P.; TORRES, F. A. G. Characterization of new variant of the yeast Cryptococcus flavus isolated from the biodversity of Brasilian Cerrado. Abstracts from the $23^{\text {rd }}$ meeting on Genetics of Microorganims, Pirenópolis, GO, Brazil, 2002.

SOMKUTI, A. G.; STEINBERG, H. D. Thermoacidophilic extracellular $\alpha$-amylase of Mucor pusillus. Devel. Ind. Microbiol., v. 21, p. 327-337, 1980.

SONI, K. S.; KAUR, A.; GUPTA, K. J. A solid state fermentation based bacterial $\alpha$-amylase and fungal glucoamilase system and its suitability for the hydrolysis of wheat starch. Process Biochem. v. 39, p. 185-192, 2003.

SOUZA-MOTTA, C. M.; CAVAlCANTI, M. A. Q.; PORTO, A. L. F.; MOREIRA, K. A.; LIMA-FILHO, J. L. Asperguillus niveus Blochwitz 4128URM: New Source for Inulinase Production. Brazilian Archives of Biology and Technology. v. 48, p. 343-350, 2005.

SPINELLI, B. B. L.; POLIZELI, M. L.; TERENZI, H. F; JORGE, J. A. Biochemical characterization of glucoamylase from the hiper producer exo-1 mutant strain of Neurospora crassa. FEMS Microbiol. Lett. v. 138, p. 173-177, 1996.

SRERE, P. A.; Y UYEDA, K. Functional groups on enzymes suitable for binding to matrices, vol XLIV (New York: Academic), 1976.

SURESH, C.; DUBEY, A. K.; SRIKANTA, S.; KUMAR, U. S. Characterization of starch hydrolyzing enzyme of Aspergillus niger. Appl Microbiol Biotechnol. v. 51, p. 673-675, 1999.

TAJ-ALDEEN, S. J.; ALKENANE, K. I. Separation and partial purification of beta-glucosidase and two endoglucanases in Aspergillus niveus. Microbiologia v. 12, p. 91-98, 1996.

TAMPION, J.; TAMPION, M. D. Inmobilized cells: priciples and applications. Cambridge University Press. p.257, 1988.

TANAKA, Y.; AKI, T.; HIDAKA, Y.; FURUYA, Y.; KAWAMOTO, S.; SHIGETA, S.; ONO, K.; SUZUKI, O. Purification and characterization of a novel fungal $\alpha$-glucosidase from Mortirella alliacea with high starch-hydrolytic activity. Biosci. Biotechnol. Biochem. v. 66, p. 2415-2423, 2002. 
THARANATHAN, R. N.; PARAMAHANS, S. V.; WANKHEDE, D. B. Amylolytic susceptibility of native groundnut and ragi starch granules as viewedby scaning electron microscopy. Starch/starke. v. 32, p. 158-161, 1980.

THORSEN, T. S.; JOHNSEN, A. H.; JOSEFSEN, K.; JENSEN, B. Identification and characterization of glucoamylase from the fungus Thermomyces lanuginosus. BBActa v. 1764, p. 671-676, 2006.

TISCHER, W. and KASCHE, V. Immobilized enzymes: Crystals or carriers? Trends in Biotechnology. v. 17, p. 326-335, 1999.

TOSI, L. R. O; TERENZI, H. F; JORGE, J. A. Purification and characterization of an extracelular glucoamylase from the thermophilic fungus Humicola grisea var thermoidea. Can. J. Microbiol. v. 39, p. 846-852, 1993.

TRABULSI, L. R.; ALTERTHUM, F. Microbiologia. 4a . ed. São Paulo: Editora Atheneu. p. 1718, 2004.

VARALAKSHMI, K. N.; KUMUDINI B. S.; NANDINI, B. N.; SOLOMON, J.; SUHAS, R.; MAHESH, B.; KAVITHA, A. P. Production and characterization of alpha-amylase from Aspergillus niger JGI 24 isolated in Bangalore. Pol. J. Microbiol. v. 58(1), p. 29-36, 2009.

VIEILLE, C.; ZEIKUS, G. J. Hiperthermophilic enzymes: Sources, uses and molecular mechanisms for termostability. Microbiol. Mol. Biol. Rev. v. 65, p.1-43, 2001.

VIHINEN, M.; MÄNTSÄLÄ, P. Microbial amylolytic enzymes. Critical Reviews in Biochemistry and Molecular Biology. v. 24, p.329-418, 1989.

WAINWRIGHT, M. Introducción a la Biotecnología de los Hongos, Editorial Acríbia, Zaragoza, Espanha, p. 228, 1995.

WANDERLEY, J. K.; TORRES, G. A. F.; MORAES, P. M. L.; ULHOA, J. C. Biochemical characterization of $\alpha$-amylase from the yeast Cryptococcus flavus. FEMS Microbiol. Letters, v. 231, p. 165-169, 2004.

WILSON, J. J.; INGLEDEW, W. M. Isolation and characterization of Schwanniomyces alluvius amylolytic enzymes. Appl. Environ. Microbiol. v. 44, p. 301-307, 1982.

WISEMAN, A. Handbook of Enzyme Biotechnology. Ltd John Wiley \& Sons, editors. Pp 148, 1975.

ZAHA, C. B.; ZEIKUS, G. Microbial glucoamylases: biochemical and biotechnological features. Starch Staerke. v. 41, p. 57-64, 1989. 
An Article Submitted to

\section{International Journal of Food Engineering}

Manuscript 1629

\section{Use of cassava peel as carbon source for production of amylolytic enzymes by Aspergillus niveus}

\author{
Tony Marcio Silva* \\ Michele Michelin** \\ Héctor Francisco Terenzi ${ }^{\S}$
}

\author{
Ricardo Fernandes Alarcon ${ }^{\dagger}$ \\ Alexandre Maller ${ }^{\dagger \dagger}$ \\ João Atílio Jorge
}

\author{
Andre Ricardo de Lima Damasio ${ }^{\ddagger}$ \\ Douglas C. Masui ${ }^{\ddagger \ddagger}$ \\ Maria de Lourdes T. M. Polizeli"
}

*São Paulo University, tonymarcio@gmail.com

†São Paulo University, ricardofa@ffclrp.usp.br

${ }^{\ddagger}$ São Paulo University, andre.damasio@gmail.com

**São Paulo University, mimichelin@yahoo.com.br

${ }^{\dagger \dagger}$ São Paulo University, alemaller@yahoo.com.br

¥†ão Paulo University, dcmasui@usp.br

§São Paulo University, hecteren@usp.br

ฯSão Paulo University, joajorge@ffclrp.usp.br

"São Paulo University, polizeli@ffclrp.usp.br

Copyright (c) 2009 The Berkeley Electronic Press. All rights reserved. 


\title{
Use of cassava peel as carbon source for production of amylolytic enzymes by Aspergillus niveus*
}

\author{
Tony Marcio Silva, Ricardo Fernandes Alarcon, Andre Ricardo de Lima \\ Damasio, Michele Michelin, Alexandre Maller, Douglas C. Masui, Héctor \\ Francisco Terenzi, João Atílio Jorge, and Maria de Lourdes T. M. Polizeli
}

\begin{abstract}
Aspergillus niveus produced high levels of $\alpha$-amylase and glucoamylase in submerged fermentation using the agricultural residue cassava peel as carbon source. In static conditions the amylase production was substantially greater than agitation condition. The optimized culture conditions were initial $\mathrm{pH} 5.0$, at $35^{\circ} \mathrm{C}$ during 48 hours. Amylolytic activity was still improved (50\%) with a mixture of cassava peel and soluble starch in the proportion 1:1 (w/w). The crude extract exhibited temperature and $\mathrm{pH}$ optima approximately $70^{\circ} \mathrm{C}$ and 4.5 , respectively. Amylase activity was stable for $1 \mathrm{~h}$ at $60^{\circ} \mathrm{C}$, and at $\mathrm{pH}$ values between 3.0 and 7.0. The enzyme hydrolysed preferentially maltose, starch, penetrose, amylose, isomaltose, maltotriose, glycogen and amylopectin, and not hydrolysed cyclodextrin ( $\alpha$ and $\beta)$, trehalose and sucrose. In the first hour of reaction on soluble starch the hydrolysis products were glucose and maltose, but after two hours of hydrolysis, glucose was the unique product formed, confirming the presence in the crude extract of an $\alpha$-amylase and a glucoamylase.
\end{abstract}

KEYWORDS: cassava peel, Aspergillus niveus, alpha-amylase, glucoamylase, submerged fermentation

*This work was supported by grants from Fundação de Amparo à Pesquisa do Estado de São Paulo (FAPESP) and Conselho de Desenvolvimento Científico e Tecnológico (CNPq). H.F.T.; J.A.J.; M.L.T.M.P. are Research Fellows of CNPq. This work is part of Doctor thesis of T. M. Silva. T. M. Silva is fellowship of FAPESP. We thank Maurício de Oliveira for technical assistance. 
Silva et al.: Production of amylolytic enzymes by Aspergillus niveus

\section{Introduction}

Cassava (Manihot esculenta Crantz) has its origin in South America and is widely cultivated in countries of tropical climate. The cassava cultivation bears a great economic relevance as a main source of carbohydrate for the population, essentially in the developing countries. Brazil is one of the largest world producers with an annual production of about 30 millions of tons of cassava roots. Cassava is produced in all regions in Brazil, presenting a highlighted importance in the human and animal feeding, besides being used as raw material in several industrial products.

The cassava peel is divided into external pellicle and cortex; it is considered as an agricultural residue because it is discarded during the cassava root processing. This residue has been used in animal feed as an energetic source replacing corn (Prado et al., 2000; Menezes et al., 2004). This purpose adds more value to a product that is discarded and also decreases the impact that this residue can cause in the environment.

Several agricultural residues have been used for microorganism growth and enzymatic production, such as sugar cane bagasse, wheat bran, rice bran, corn bran, rice peel, wheat straw, cassava flour and corn flour. Residues of the cassava root processing have been used for amylolytic enzymes production (Reddy and Bassappa, 1996; Figueroa et al., 2001; Swain and Ray, 2007; González et al., 2008); however, the use of cassava peel for this purpose has not been evaluated.

Amylolytic enzymes have been produced from bacteria, fungi and other organisms (Vihinen and Mäntsälä, 1989; Gupta et al., 2003; Wanderley et al., 2004). The industrial demand for these enzymes is restricted by the specific applications in the food industry, where fungal amylases are preferred over other microbial sources, mainly because of their more accepted GRAS status (Prakasham et al., 2007). Based on that, the aim of this work was to determine the optimal operative conditions for amylolytic enzymes production by filamentous fungus Aspergillus niveus when cultured with cassava peel as carbon source as an amylolytic inductor.

\section{Methods}

\subsection{Microorganism, maintenance and growth conditions}

Aspergillus niveus was isolated from Mangifera indica in our laboratory. The microorganism was identified and deposited in the culture collection of the Pernambuco Federal University (PE, Brazil). The organism was maintained on slants of PDA medium covered with mineral oil and stored at $4^{\circ} \mathrm{C}$. Approximately 
$10^{7}$ conidia/ml from 3-day-old cultures were inoculated into $125 \mathrm{ml}$ Erlenmeyer flasks containing $25 \mathrm{ml}$ of modified Khanna medium (Khanna et al., 1995) (0.1\% yeast extract, $5 \%$ Khanna salt solution $\left(2 \% \mathrm{NH}_{4} \mathrm{NO}_{3}, 1.3 \% \quad \mathrm{KH}_{2} \mathrm{PO}_{4}, 0.36 \%\right.$ $\mathrm{MgSO}_{4} .7 \mathrm{H}_{2} \mathrm{O}, 0.1 \% \mathrm{KCl}, 0.07 \% \quad \mathrm{ZnSO}_{4} \cdot \mathrm{H}_{2} \mathrm{O}, 0.014 \% \quad \mathrm{MnSO}_{4} . \mathrm{H}_{2} \mathrm{O}, 0.007 \%$ $\left.\mathrm{Fe}_{2}\left(\mathrm{SO}_{4}\right)_{3} \cdot 6 \mathrm{H}_{2} \mathrm{O}, 0.006 \% \mathrm{CuSO}_{4} .5 \mathrm{H}_{2} \mathrm{O}\right)$ and $1 \%$ cassava peel treated as described below. After inoculation, the cultures were kept in initial $\mathrm{pH}$ and temperature was controlled. After filtration of the culture in a Büchner funnel, the filtrate was used as a source of crude extracellular amylolytic activity.

\subsection{Preparation of cassava peel}

The cassava roots were bought in the local trade. The first stage of the treatment consisted in the separation of the peel from the root and external pellicle. After that, the cassava peel was dried during 3 days, at $60^{\circ} \mathrm{C}$, and triturated until powder in porcelain in mortar with the aid of a pestle. The powder cassava peel was used as the carbon source for microorganism growth and amylolytic enzyme production.

\subsection{Determination of amylase activity}

The amylolytic activity was routinely assayed with $1 \%$ soluble commercial starch

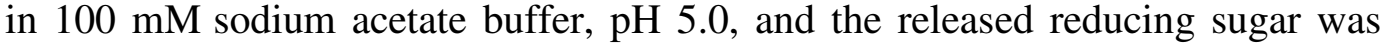
determined by the Miller method (Miller, 1959). One enzyme unit was defined as the amount that releases reducing sugar at an initial rate of $1 \mu \mathrm{mol} \mathrm{min}{ }^{-1}$ at the temperature optimum of the enzyme (in this case $70^{\circ} \mathrm{C}$, see results). Extracellular protein was determined by the Lowry method (Lowry et al., 1951) using bovine serum albumin as standard.

\subsection{Cultivation conditions optimization}

The medium components and other parameters for amylase production were optimized by keeping all parameters at a constant level, except for the one being investigated. Each subsequent parameter was examined after taking into account the previously optimized condition. All the experiments were performed in triplicate, and their mean values are presented.

Amylase production was studied at regular intervals of $24 \mathrm{~h}$ up to 6 days. To study the effect of $\mathrm{pH}$, the fungus was cultivated in the basal medium buffered at different $\mathrm{pH}(3.5-7.5)$. The effects of physical conditions, static and agitation conditions were at $100 \mathrm{rpm}$, at $35^{\circ} \mathrm{C}$ by $144 \mathrm{~h}$. The effect of temperature was carried out by cultivating the fungus at different temperatures $\left(25-50^{\circ} \mathrm{C}\right)$. 
Silva et al.: Production of amylolytic enzymes by Aspergillus niveus

\subsection{Enzymatic characterization}

The $\mathrm{pH}$ optimum was determined at $60^{\circ} \mathrm{C}$ using citrate-phosphate buffer (3.0-8.0 $\mathrm{pH}$ range). The $\mathrm{pH}$ stability was determined at $30^{\circ} \mathrm{C}$, for $24 \mathrm{~h}$, after pre-incubation of the diluted enzyme in citrate phosphate buffer at different $\mathrm{pH}$ values (3.0-8.0 $\mathrm{pH}$ range). The temperature optimum was determined with $0.1 \mathrm{M}$ sodium acetate buffer, $\mathrm{pH}$ 5.5. The thermostability was determined by measuring the residual activity after incubation of the diluted enzyme in the absence of substrate at $60^{\circ} \mathrm{C}$ in $0.1 \mathrm{M}$ sodium acetate buffer $\mathrm{pH} 5.0$ for $6 \mathrm{~h}$. For the determination of the $\mathrm{pH}$ and temperature stabilities, the enzymatic assays were carried out using $1 \%$ soluble starch as substrate.

\subsection{Identification of hydrolysis products}

The hydrolysis products of the amylase activity against $1 \%$ soluble starch as substrate were analyzed through thin-layer chromatography (TLC). The mobile phase was butanol/ethanol/water (5:3:2). Sugars were determined with $0.2 \%$ orcinol in a 9:1 methanol-sulfuric acid mixture (Aquino et al., 2003). Glucose, maltose, maltotriose, maltotetraose and maltopentaose were used as standards.

\subsection{Amylolytic activity in polyacrylamide gel electrophoresis (PAGE).}

Non-denaturing polyacrylamide gel electrophoresis (PAGE) was performed in 5$10 \%$ gels according to Davis (1964). After running, the gel was incubated with 0.5 $\mathrm{M}$ acetate buffer, pH 5.0 for $30 \mathrm{~min}$ and immediately immersed in $1 \%$ starch solution. The gel was incubated for $20 \mathrm{~min}$ and amylolytic activity determined with a mixture $0.3 \%$ of $\mathrm{KI}$ and $0.15 \% \mathrm{I}_{2}$ until the appearance of the bands with amylolytic activity.

\subsection{Reproducibility of the results}

All data are the mean of at least three independent experiments showing consistent results.

\section{Results and discussion}

\subsection{Determination of physical parameters}

Time course and influence of aeration versus static conditions in fungus growth and amylase production were monitored for 6 days. High differences were observed from agitated and static cultures. The amylolytic activity was about 3 - 
fold higher, for $48 \mathrm{~h}$, in static cultures rather than in agitated culture (Figure $1 \mathrm{~A}$ ). Similar results are reported for amylolytic activity from Rhizopus microsporus var. rhizopodiformis (Peixoto et al., 2003).

\subsection{Initial pH, temperature and addition of soluble starch in culture medium for the amylase production}

The fungus produced amylases in all $\mathrm{pH}$ tested; however, the optimal production occurred at $\mathrm{pH}$ 6.5. Figure $1 \mathrm{~B}$ shows the enzymatic production in different initial $\mathrm{pH}$. It is possible to associate these results with the nutritional and physiologic necessities of the microorganism, once that the highest growth was also evidenced in this $\mathrm{pH}$ range (data not shown). These results were similar to those reported for Aspergillus fumigatus (Goto et al., 1998) and Aspergillus oryzae Ahlburg (Cohen) 1042.72 (Bennamoun et al., 2004). The maximum enzymatic activity was at $35^{\circ} \mathrm{C}$ when the fungus grew between $25-50^{\circ} \mathrm{C}$, but similar amylolytic activity levels were produced at $40^{\circ} \mathrm{C}$. These results suggested that $A$. niveus might be a thermotolerant fungus, which grew better under lower oxygen tension at higher temperatures. The temperatures for amylases production by Rhizopus microsporus var. rhizopodiformis, Thermomyces lanuginosus (ATCC 34626) and Rhizomucor pusilus A 13.36 lineages were 45,47 and $45^{\circ} \mathrm{C}$, respectively (Nguyen et al., 2002; Peixoto et al., 2003; Silva et al., 2005).

Similar levels of amylolytic activity were determined in soluble starch and cassava peel-medium. Interestingly, an increase of 50\% was observed with the mixture of soluble starch and cassava peel in the proportion of 1:1 (w/w) (Figure $1 \mathrm{D})$. This datum is important once that cassava peel consists of an agricultural residue discarded during cassava root processing. The use of this residue decreased the cost of enzymatic production because it replaces starch and derivates, which need to be processed. 
Silva et al.: Production of amylolytic enzymes by Aspergillus niveus
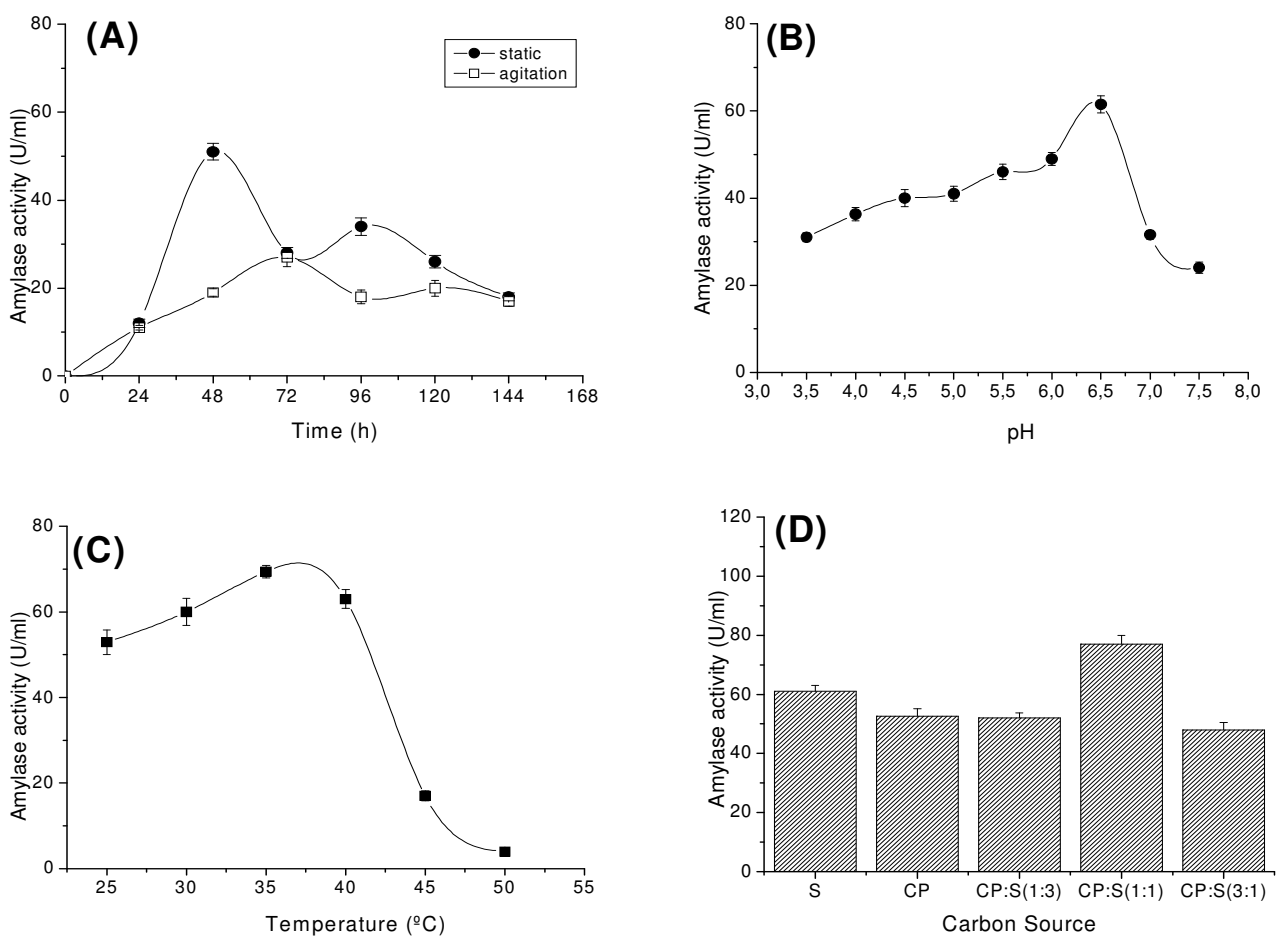

Figure 1. Time-course of growth and amylase production in agitated and static conditions (A). Initial $\mathrm{pH}$ of culture (B). Influence of temperature on amylase production (C) and effect of addition of soluble starch in culture medium on the amylase production (D). S - starch, CP - cassava peel.

\subsection{Effects of $\mathrm{pH}$ and temperature on amylolytic activity assay}

The effect of $\mathrm{pH}$ on the enzyme activity is shown in Figure 2A. Optimum enzyme activity was observed to be $\mathrm{pH}$ 4.0-5.0. The amylolytic activity of A. niveus was acid-alkaline tolerant, remained stable over a $\mathrm{pH}$ range of $4.0-7.0$ after $24 \mathrm{~h}$ incubation (Figure 2B). The temperature optimum of the glucoamylase from $A$. niveus was $70^{\circ} \mathrm{C}$ (Figure $2 \mathrm{C}$ ). This activity temperature is considered as higher than those determined for mesophilic lineages of A. terreus (Ali and Hossain, 1991), A. terreus NA-170 (Ghosh et al., 1991) and A. fumigatus (Silva and Peralta, 1998). The enzymes were shown to be completely stable during 6 hours when incubated at $55^{\circ} \mathrm{C}$ and retained $50 \%$ of their activity after four hours at $60^{\circ} \mathrm{C}$ (Figure 2D). These data are important for applications in industrial processes demanding long-time periods of application at elevated temperatures. 

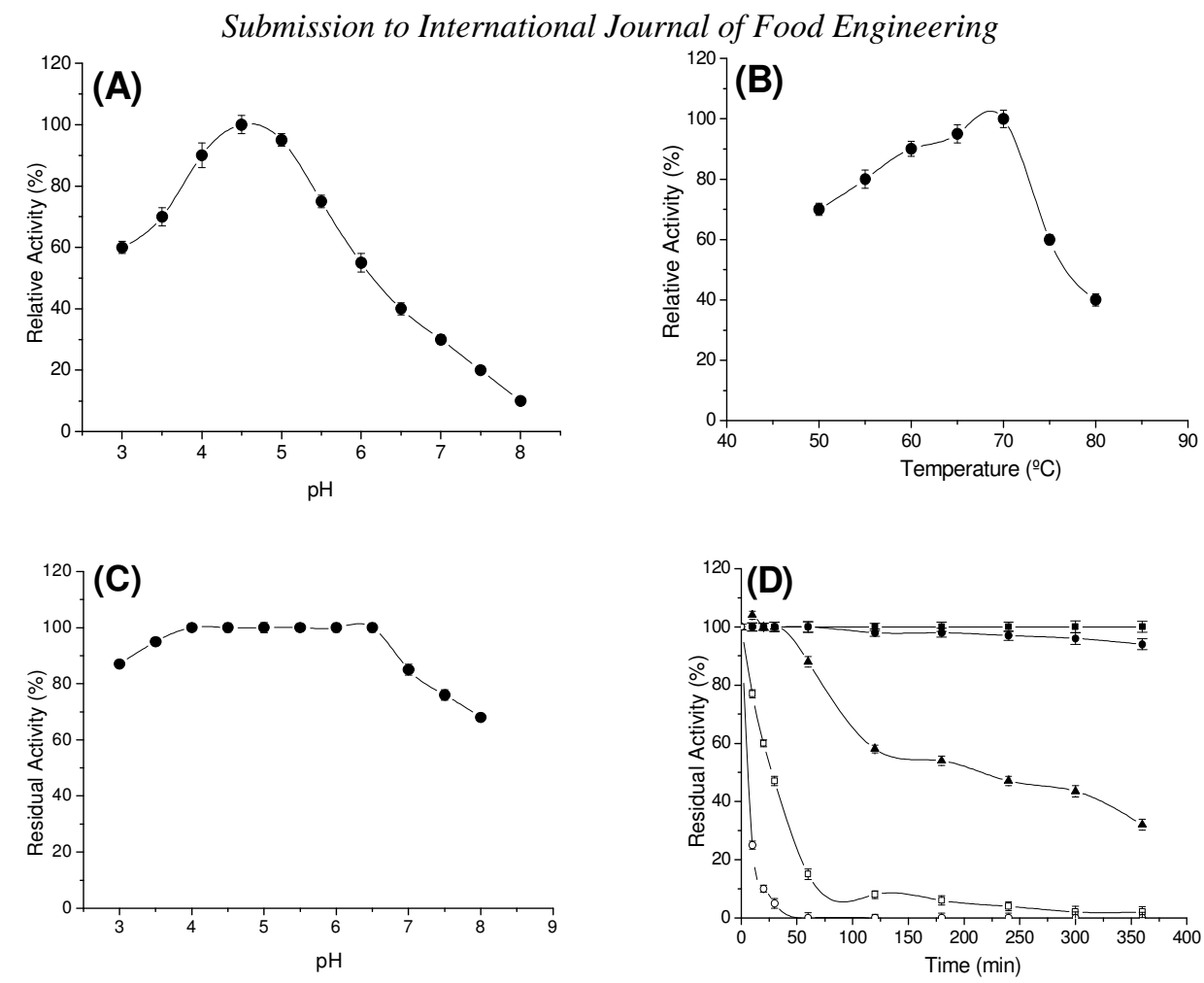

Figure 2. Influence of $\mathrm{pH}$ and temperature on amylolytic activity A and B. Stability of the amylolytic activity at different $\mathrm{pHs} \mathrm{C}$. Stability of the amylolytic activity at different temperatures D. closed squares $50^{\circ} \mathrm{C}$, closed circle $55^{\circ} \mathrm{C}$, closed triangles $60^{\circ} \mathrm{C}$, open square $65^{\circ} \mathrm{C}$ and open circle $70^{\circ} \mathrm{C}$.

\subsection{Hydrolysis of different substrates, TLC of hydrolysis products and amylolytic activity in polyacrylamide gel electrophoresis (PAGE).}

The amylases from Aspergillus niveus hydrolyzed efficiently (70-100\%) maltose, soluble starch, penetrose, amylose, isomaltose and maltotriose. Considerable activity was observed in glycogen and amylopectin (50 and 46\%) respectively. Cyclodextrin $(\alpha$ and $\beta$ ), trehalose and sucrose were not hydrolysed (Table 1). The crude amylase obtained from optimized conditions was assayed with $1 \%(\mathrm{w} / \mathrm{v})$ commercial starch, and hydrolysis products were analyzed by TLC (Figure 3 ). It was observed that until $60 \mathrm{~min}$ of reaction, glucose and maltose were accumulated, suggesting the concomitant presence of traces of $\alpha$-amylase and a glucoamylase in the crude extract, once that after this time glucose was the main product. Less common is the occurrence of an organism that produces both enzymes simultaneously, as A. niveus. A similar situation was observed for 
Silva et al.: Production of amylolytic enzymes by Aspergillus niveus

amylases from Rhizopus microsporus var. rhizopodiformis (Peixoto-Nogueira et al., 2008).

The crude extract containing amylolytic activity was applied in nondenaturing polyacrylamide gel electrophoresis (PAGE) (Figure 4). It is possible to verify the presence of at least 4 bands with amylolytic activity. This is an interesting phenomenon, because some of these enzymes might be used together in different stages of starch saccharification.

Table 1. Amylase activity on different substrates

\begin{tabular}{lc}
\hline \multicolumn{1}{c}{ Substrate } & $(\boldsymbol{\%})$ \\
Soluble starch & $100 \pm 1.8$ \\
Maltose & $106 \pm 1.2$ \\
Amylose & $88 \pm 1.6$ \\
Amylopectin & $46 \pm 1.5$ \\
Glycogen & $50 \pm 1.0$ \\
Penetrose & $100 \pm 2.1$ \\
Maltotriose & $70 \pm 1.9$ \\
Isomaltose & $86 \pm 0.9$ \\
Cyclodextrin $(\alpha$ e $\beta)$ & 0 \\
Trehalose & 0 \\
Sucrose & 0 \\
\hline
\end{tabular}




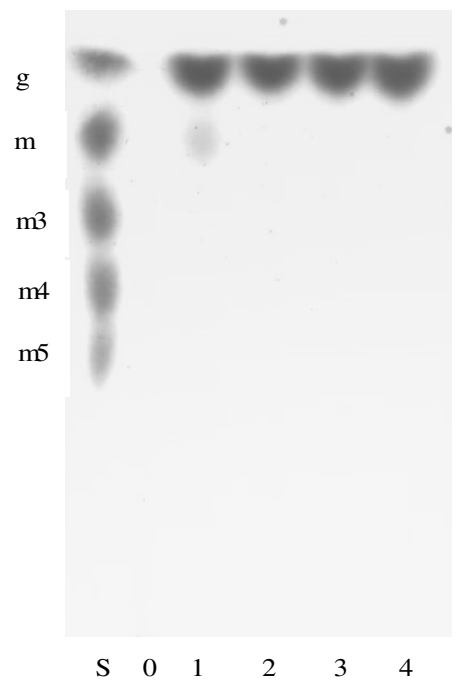

Figure 3. Analysis of the hydrolysis products released by amylase acting on $1.0 \%(\mathrm{w} / \mathrm{v})$ starch for different times $(0,1,2,3$ and 4 hours). The fungus was cultivated in static conditions, at $35^{\circ} \mathrm{C}$ for $48 \mathrm{~h}$; g: $1 \%(\mathrm{w} / \mathrm{v})$ glucose, $\mathrm{m}: 1 \%(\mathrm{w} / \mathrm{v})$ maltose, $\mathrm{m} 3: 1 \%(\mathrm{w} / \mathrm{v})$ maltotriose, $\mathrm{m} 4: 1 \%(\mathrm{w} / \mathrm{v})$ maltotetraose, $\mathrm{m} 5: 1 \%(\mathrm{w} / \mathrm{v})$ maltopentaose and S- standard.

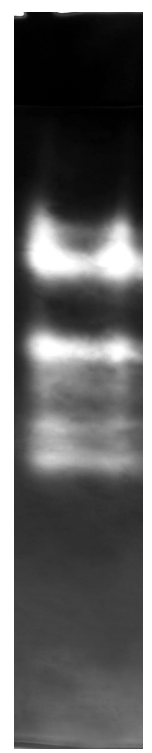

Figure 4. Amylolytic activity on PAGE contained $1 \%$ starch. 
Silva et al.: Production of amylolytic enzymes by Aspergillus niveus

\section{Conclusion}

The use of the cassava processing residues (Manihot esculenta Crantz) is shown as a good alternative source in the amylase production, being a product of great potential in Brazil. The thermotolerant fungus A. niveus produced high amylase levels using agro industrial residue (cassava peel) as carbon source. This residue is obtained from the cassava root processing and it is accumulated in the environment causing serious pollution problems. The use of cassava peel for enzymatic production might add values to the residue that is discarded, while it also decreases the cost of the enzymatic production. The amylolytic enzymes produced by $A$. niveus fungus are suitable for biotechnological applications, considering the high productivity of these enzymes, the good capacity to degrade starch and its derivates and also the biochemical characteristics as elevated temperature activity and stability.

\section{References}

1. Ali S., Hossain Z., "Characteristics for glucoamylase from Aspergillus terreus", Journal of Applied Bacteriology, 1991, 71, 144-146

2. Aquino A.C.M.M., Jorge J.A., Terenzi H.F., Polizeli M.L.T.M., "Studies on a thermostable $\alpha$-amylase from thermophilic fungus Scytalidium thermophilum", Applied Microbiology and Biotechnology, 2003, 61, 323-8

3. Bennamoun L., Meraihi Z., Dakhmouche S., "Utilisation de la planification expérimentale pour 1'optimisation de la production de 1' $\alpha$-amylase par Aspergillus oryzae Ahlburg (Cohen) 1042.72 cultivé sur milieu à base de déchets d'oranges", Journal of Food Engineering, 2004, 64, 257-264

4. Davis B.J., "Disc electrophoresis. II. Method and application to human serum proteins", Annals of the New York Academy Sciences, 1964, 121, 404-427

5. Figueroa L.I.C., Rubinstein L., González C., "Utilization of native cassava starch by yeast", In: Spencer J. F. T., de Spencer A. L. R., editors, Methods in Biotechnology, Food Microbiology Protocols, Totowa, New Jersey: Humana Press, 2001, 307-317

6. Ghosh A., Chatterjee B., Das A., "Purification and characterization of glucoamylases of Aspergillus terreus NA-170 mutant", Journal of Applied Bacteriology, 1991, 71, 162-169 
7. González C.F., Fariña J.I., Figueroa L.I.C., “Optimized amylolytic enzymes production in Saccharomycopis fibuligera DSM-70554. An approach to efficient cassava starch utilization", Enzyme and Microbiol Technology, 2008, $42,272-277$

8. Goto C.E., Barbosa E.P., Kistner L.C.L., Ganda R.F., Arrias V.L., Peralta R.M., "Production of amylases by Aspergillus fumigatus", Revista de Microbiologia, 1998, 29, 99-103

9. Gupta R., Gigras P., Mohapatra H., Goswami V.K., Chauhan B., "Microbial $\alpha$-amylases: a biotechnological perspective", Process Biochemistry, 2003, 38, $1599-616$

10. Khanna P., Sundari S.S., Kumar N.J., "Production, isolation and partial purification of xylanase from Aspergillus sp", World Journal of Microbiol and Biotechnology, 1995, 11, 242-243

11. Lowry O.H., Rosebrough N.J., Farr A.L., Randall R.J., "Protein measurement with the Folin phenol reagent", Journal of Biological Chemistry, 1951, 193, 267-275

12. Menezes M.P.C., Ribeiro M.N., Costa R.G., Medeiros A.N., "Substitution of corn by cassava (Manihot esculenta Crantz) peel in complete rations for goats: intake, digestibility and weight gain”, Revista Brasileira de Zootecnia, 2004, 33, 729-737

13. Miller G.L., "Use of dinitrosalicylic acid reagent for determination of reducing sugar”, Analytical Chemistry, 1959, 31, 426-489

14. Nguyen Q.D., Rezessy-szabó J.M., Claeyssens M., Stals I., Hoschke A., "Purification and characterization of amylolytic enzymes from thermophilic fungus Thermomyces lanuginosus strain ATCC 34626", Enzyme and Microbial Technology, 2002, 31, 345-352

15. Peixoto S.C., Jorge J.A., Terenzi H.F., Polizeli M.L.T.M., Rhizopus microsporus var. rhizopodiformis: a thermotolerant fungus with potential for production of thermostable amylases", International Microbiology, 2003, 6, 269-273

16. Peixoto-Nogueira S.C., Sandrim V.C., Guimarães L.H.S., Jorge J.A., Terenzi H.F., Polizeli M.L.T.M., "Evidence of thermostable amylolytic activity from Rhizopus microsporus var. rhizopodiformis using wheat bran and corncob as alternative carbon source", Bioprocess and Biosystem Engineering, 2008, 31, 329-334

17. Prado I.N., Martins A.S., Alcalde C.R., Zeoula L.M., Marques J.A., "Performance of heifers fed diets containing corn or cassava hull as energy 
Silva et al.: Production of amylolytic enzymes by Aspergillus niveus

source and cottonseed meal or yeast as protein source", Revista Brasileira de Zootecnia, 2000, 29, 278-287

18. Prakasham, R.S., Subba Rao C.H., Rao R.S., Sarma P.N., "Enhancement of acid amylase production by an isolated Aspergillus awamori", Journal of Applied Microbiology, 2007, 102, 204-211

19. Reddy O.V.S., Bassappa S.C., "Direct fermentation of cassava starch to ethanol by mixed cultures of Endomycopsis fibuligera and Zymomonas mobilis; synergism and limitations", Biotechnology Letters, 1996, 18, 13151318

20. Silva T.M., Attili-Angelis D., Carvalho A.F.A., Da Silva R., Gomes E., "Production of sacharogenic and dextrinogenic amylases by Rhizomucor pusillus A 13.36", Journal of Microbiology (Korea), 2005, 43, 561-568

21. Silva W.B., Peralta R.M., "Purification and characterization of a thermostable glucoamylase from A. fumigatus", Canadian Journal of Microbiology, 1998, 44, 493-497

22. Swain M.R., Ray R.C., "Alpha-amylase production by Bacillus subtilis CM3 in solid state fermentation using cassava fibrous residue", Journal Basic of Microbiology, 2007, 47, 517-425

23. Vihinen M., Mäntsälä P., "Microbial amylolytic enzymes" (Review), Critical Reviews in Biochemistry and Molecular Biology, 1989, 24 (4), 329-419

24. Wanderley J.K., Torres G.A.F., Moraes P.M.L., Ulhoa J.C., "Biochemical characterization of $\alpha$-amylase from the yeast Cryptococcus flavus", FEMS Microbiology Letters, 2004, 231, 165-169 


\title{
Purification and biochemical characterization of a novel $\alpha$-glucosidase from Aspergillus niveus
}

\author{
Tony Marcio da Silva • Michele Michelin · Andre Ricardo de Lima Damásio • \\ Alexandre Maller · Fausto Bruno Dos Reis Almeida - Roberto Ruller · \\ Richard John Ward · José Cesar Rosa · João Atilio Jorge · Héctor Francisco Terenzi · \\ Maria de Lourdes Teixeira de Moraes Polizeli
}

Received: 7 May 2009/ Accepted: 10 August 2009

(C) Springer Science+Business Media B.V. 2009

\begin{abstract}
An extracellular $\alpha$-glucosidase produced by Aspergillus niveus was purified using DEAEFractogel ion-exchange chromatography and Sephacryl S-200 gel filtration. The purified protein migrated as a single band in 5\% PAGE and 10\% SDS-PAGE. The enzyme presented $29 \%$ of glycosylation, an isoelectric point of 6.8 and a molecular weight of 56 and $52 \mathrm{kDa}$ as estimated by SDS-PAGE and Bio-Sil-Sec-400 gel filtration column, respectively. The enzyme showed typical $\alpha$-glucosidase activity, hydrolyzing $p$-nitrophenyl $\alpha$-D-glucopyranoside and presented an optimum temperature and $\mathrm{pH}$ of $65^{\circ} \mathrm{C}$ and 6.0 , respectively. In the absence of substrate the purified $\alpha$-glucosidase was
\end{abstract}

T. M. da Silva - M. Michelin - J. A. Jorge ·

H. F. Terenzi · M. de Lourdes Teixeira de Moraes

Polizeli ( $\square)$

Departamento de Biologia, FFCLRP, Universidade de São

Paulo, Avenida Bandeirantes 3900, Monte Alegre,

Ribeirão Preto, SP 14.040-901, Brazil

e-mail: polizeli@ffclrp.usp.br

A. R. de Lima Damásio · A. Maller

Departamento de Bioquímica e Imunologia, FMRP,

Universidade de São Paulo, Ribeirão Preto, Brazil

R. Ruller · R. J. Ward

Departamento de Química, FFCLRP, Universidade de São Paulo, Ribeirão Preto, Brazil

F. B. D. R. Almeida · J. C. Rosa

Centro de Química de Proteínas e Departamento de Biologia Celular e Molecular e Bioagentes Patogênicos,

FMRP, Universidade de São Paulo, Ribeirão Preto, Brazil stable for $60 \mathrm{~min}$ at $60^{\circ} \mathrm{C}$, presenting $t_{50}$ of $90 \mathrm{~min}$ at $65^{\circ} \mathrm{C}$. Hydrolysis of polysaccharide substrates by $\alpha$-glucosidase decreased in the order of glycogen, amylose, starch and amylopectin. Among malto-oligosaccharides the enzyme preferentially hydrolyzed malto-oligosaccharide (G10), maltopentaose, maltotetraose, maltotriose and maltose. Isomaltose, trehalose and $\beta$-ciclodextrin were poor substrates, and sucrose and $\alpha$-ciclodextrin were not hydrolyzed. After $2 \mathrm{~h}$ incubation, the products of starch hydrolysis measured by HPLC and thin layer chromatography showed only glucose. Mass spectrometry of tryptic peptides revealed peptide sequences similar to glucan 1,4-alpha-glucosidases from Aspergillus fumigatus, and Hypocrea jecorina. Analysis of the circular dichroism spectrum predicted an $\alpha$-helical content of $31 \%$ and a $\beta$-sheet content of $16 \%$, which is in agreement with values derived from analysis of the crystal structure of the $H$. jecorina enzyme.

Keywords Aspergillus niveus $\cdot \alpha$-Glucosidase · Purification · Thermostability · Fungus

\section{Introduction}

Amylases are hydrolyzing enzymes used by many organisms, such as plants for assimilation of the starch accumulated in roots, animals for the digestion of starch present in food and prokaryotic and eukaryotic microbes use starch as a carbon source (Pandey et al. 2000; 
Michelin et al. 2008). $\alpha$-Glucosidase ( $\alpha$-D-glucoside glucohydrolase; EC 3.2.1.20) hydrolyses the $\alpha$-glycosidic bonds from the non-reducing end of oligo- and poly-saccharides with immediate release of glucose.

These enzymes are conventionally classified according to their substrate specificity. Type I $\alpha$-glucosidases hydrolyze aryl glucosides, such as $p$-nitrophenyl $\alpha$-D-glucopyranoside (pNPG) faster than short malto-oligosaccharides. Type II enzymes are more active on maltose and have low activity towards aryl glucosides. Type III enzymes resemble type II, but hydrolyze oligosaccharides and starch at similar rates (Marín et al. 2006). Some $\alpha$-glucosidases are capable of transglycosylation, an activity that has applications in the industrial production of isomaltooligosaccharides and in the conjugation of sugars to biologically useful materials (Kato et al. 2002). Another type of $\alpha$-glucosidase converts malto-oligosaccharides into trehalose via intramolecular transglycosylation, and this ATP-independent enzymatic route for trehalose synthesis was first described for prokaryotic organisms Pimelobacter sp. and Arthrobacter sp. (Nishimoto et al. 1995; Maruta et al. 1995). Among fungal species this activity is also been observed in the $\alpha$-glucosidase from Chaetomium thermophilum var. coprophilum, that is a key reaction in the conversion of maltose into trehalose (Giannesi et al. 2006).

In the present study we demonstrate that the amylolytic capacity of Aspergillus niveus is due to an extracellular exo-acting $\alpha$-glucosidase that hydrolyses $\alpha-1-4$ glycosidic bonds, producing glucose from malto-oligosaccharides, glycogen and soluble starch substrates. Biochemical properties of the enzyme, including optima $\mathrm{pH}$ and temperature, stability at different temperatures and substrate specificity were analyzed, which together with the broad substrate preference indicate that the enzyme may be suitable for a range of applications involving saccharification of plant polysaccharides.

\section{Materials and methods}

Organism and growth conditions

Aspergillus niveus was isolated from Mangifera indica in our laboratory, and after identification the microorganism was deposited in the culture collection of the Pernambuco Federal University (PE, Brazil). The organism was maintained in slants of PDA medium covered with mineral oil at $4^{\circ} \mathrm{C}$. Approximately $10^{7}$ conidia/ml from 3-day-old cultures were inoculated into $125 \mathrm{ml}$ Erlenmeyer flasks containing $25 \mathrm{ml}$ modified Khanna medium (Khanna et al. 1995) as follows: $0.1 \%$ yeast extract, $5 \%$ Khanna salt solution $\left(2 \% \mathrm{NH}_{4} \mathrm{NO}_{3}, 1.3 \% \mathrm{KH}_{2} \mathrm{PO}_{4}, 0.36 \% \mathrm{MgSO}_{4} \cdot 7 \mathrm{H}_{2} \mathrm{O}\right.$, $0.1 \% \mathrm{KCl}, 0.07 \% \mathrm{ZnSO}_{4} \cdot \mathrm{H}_{2} \mathrm{O}, 0.014 \% \mathrm{MnSO}_{4} \cdot \mathrm{H}_{2} \mathrm{O}$, $\left.0.007 \% \mathrm{Fe}_{2}\left(\mathrm{SO}_{4}\right)_{3} \cdot 6 \mathrm{H}_{2} \mathrm{O}, 0.006 \% \mathrm{CuSO}_{4} \cdot 5 \mathrm{H}_{2} \mathrm{O}\right)$ and $1 \%$ starch. After inoculation, the media were maintained in B.O.D, under static conditions at an initial $\mathrm{pH} 6.5$ and $40^{\circ} \mathrm{C}$ for $72 \mathrm{~h}$. Culture filtrates were obtained by filtration through filter paper in a Büchner funnel. The filtrate was used as a source of crude extracellular amylolytic activity.

Purification of $\alpha$-glucosidase

All steps were carried out at $4^{\circ} \mathrm{C}$. The culture filtrate was dialyzed overnight against $10 \mathrm{mM}$ Tris- $\mathrm{HCl}$ buffer, $\mathrm{pH} 7.5$, and adsorbed on DEAE-Fractogel TSK $650 \mathrm{M}$ column $(2.0 \times 7.0 \mathrm{~cm})$ equilibrated with the same buffer, and eluted with $200 \mathrm{ml}$ of a linear gradient $(0-1 \mathrm{M})$ of sodium chloride prepared with the same buffer. The fractions showing amylolytic activity were pooled, dialyzed against distilled water, lyophilized and suspended in $2 \mathrm{ml}$ of $100 \mathrm{mM}$ sodium acetate buffer, $\mathrm{pH}$ 5.0. This sample was adsorbed on Sephacryl S-200 gel filtration column $(2.0 \times 85 \mathrm{~cm})$ equilibrated and eluted in $100 \mathrm{mM}$ sodium acetate buffer, $\mathrm{pH} 5.0$ at a flow rate of $18 \mathrm{ml} \mathrm{h}^{-1}$. The absorbance of the eluate was monitored at $280 \mathrm{~nm}$, and a volume of $1 \mathrm{ml}$ was collected in each fraction. The fractions containing enzymatic activity were pooled and used for further characterization.

Enzymatic assays, determination of protein, sugar content and kinetic constant

$\alpha$-Glucosidase activity was determined by measuring the production of reducing sugar using 3',5-dinitrosalicylic acid (DNS) as described by Miller (1959). The assay was carried out at $65^{\circ} \mathrm{C}$ using $1.0 \%$ starch solution in $0.1 \mathrm{M}$ sodium acetate buffer, $\mathrm{pH}$ 5.0. In addition, the enzyme activity was measured according to Cereia et al. 2000, using soluble starch as substrate, in which the amount of glucose released was estimated by peroxidase/glucose oxidase. When $p$-nitrophenyl- $\alpha$-D-glucopyranoside ( $\alpha$-PNPG) was used 
as substrate, activity was measured in a mixture containing $0.2 \mathrm{ml} 0.1 \mathrm{M}$ sodium acetate, $\mathrm{pH} 5.0$, $0.05 \mathrm{ml}$ of $2 \mathrm{mM}$ substrate solution, and $0.1 \mathrm{ml}$ of enzyme. After $5 \mathrm{~min}$ of incubation at $65^{\circ} \mathrm{C}$, the reaction was stopped with $1 \mathrm{ml}$ of $2 \mathrm{M} \mathrm{NaCO}_{3}$, and the $p$ nitrophenolate released was quantified spectrophotometrically at $410 \mathrm{~nm}$. One unit (U) of enzyme activity was defined as the amount of enzyme that releases $1 \mu \mathrm{mol}$ of glucose per minute per $\mathrm{ml}$ reaction mixture.

Protein concentration was estimated as described by Lowry et al. (1951) using bovine serum albumin as a standard. Total neutral carbohydrate was quantified by the phenol-sulfuric acid method (Dubois et al. 1956), using D-mannose as standard. In order to determine which substrate was hydrolyzed most efficiently, the apparent kinetic parameters $K_{m}$ and $K_{\text {cat }}$ of the purified enzyme were determined using (3-12 mg) starch, amylopectin, maltose and glycogen or $(0.05-10 \mathrm{mM}$ of $\alpha$-PNPG). The reactions were carried out at $65^{\circ} \mathrm{C}$ (optimum temperature), $\mathrm{pH} 6.0$ and the apparent $K_{m}$ values were calculated from Hanes plots (Hanes 1932).

Polyacrylamide gel electrophoresis analysis

Polyacrylamide gel electrophoresis performed under non-denaturing conditions (5\% PAGE) was carried out by the method of Davis (1964) and under denaturing conditions (10\% SDS-PAGE) according to Laemmli (1970). The proteins were stained with $0.25 \%$ Coomassie Brilliant Blue R-250 and destained with methanol-acetic acid-water (3:1:6). $\alpha$-Glucosidase activity in non-denaturing polyacrylamide gels was detected using starch as substrate, where starch was added to the gel mixture at a final concentration of $1 \%$, and after electrophoresis the gel was incubated at $60^{\circ} \mathrm{C}$ for $30 \mathrm{~min}$, and subsequently immersed in a $0.15 \%$ iodine solution. Isoelectric focusing was carried out according to O'Farrel et al. (1977) using Pharmalite (pH 3.0-10.0).

\section{Chromatography of hydrolysis products}

Chromatographic analysis of the reaction end-products of the $\alpha$-glucosidase activity against with $1.0 \%$ soluble starch solution was carried out using thin layer chromatography (TLC) and high performance liquid chromatography (HPLC). A volume of $10 \mu \mathrm{l}$ of the reaction mixture was applied on silica gel plates (DC-Alufolien Kieselgel 60, Merck), and subjected to two sequential ascending chromatography runs using butanol/ethanol/water $(5: 3: 2)$ as the solvent system. After air-drying the plate, the spots were developed by spraying $0.2 \%$ orcinol solution in $\mathrm{H}_{2} \mathrm{SO}_{4}$ and methanol (1:9), and heating at $100^{\circ} \mathrm{C}$ (Fontana et al. 1988). Reaction products were also analyzed by HPLC, using a Nucleosil-NH2 column, where the mobile phase was acetonitrille and water (80:20\%),

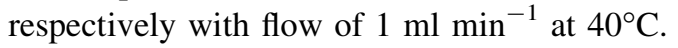

\section{Circular dichroism experiments}

Far UV CD spectra (180-250 nm) were measured with a JASCO 810 spectropolarimeter (JASCO Inc., Tokyo, Japan) using $0.1 \mathrm{~mm}$ pathlength cuvettes and $0.36 \mathrm{mg} \mathrm{ml}^{-1}$ of native $\alpha$-glucosidase. All measurements were performed in $20 \mathrm{mM}$ sodium acetate buffer ( $\mathrm{pH} \mathrm{5.5)}$ at $25^{\circ} \mathrm{C}$. A total of twelve spectra were collected, averaged and corrected by subtraction of a blank containing $20 \mathrm{mM}$ sodium acetate buffer $\mathrm{pH}$ 5.5. The secondary structure content of the protein was estimated from the averaged and corrected far UVCD spectrum using the K2D algorithm (Andrade et al. 1993).

Gel in situ trypsin digestion and mass spectrometry analysis

The Coomassie Blue stained protein band corresponding to $\alpha$-glucosidase was separated by SDS-PAGE, and after extensive washing was submitted to in situ trypsin gel digestion with $0.5 \mu \mathrm{g}$ of modified trypsin (Promega Corporation, Madison, WI, USA). The tryptic peptides were extracted and desalted in microTip filled with POROS R2 (PerSeptive Biosystems, Foster City, CA) previously equilibrated in $0.2 \%$ formic acid and eluted in $60 \%$ methanol and $5 \%$ formic acid for mass spectrometry analysis. Mass spectrometry analysis was carried out in electrospray triple-quadrupole mass spectrometer Quattro II (Micromass, Manchester, UK) by direct infusion by

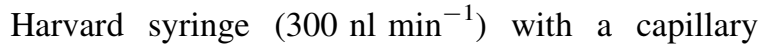
voltage of $3.5 \mathrm{kV}$, a cone voltage of $40 \mathrm{~V}$, and a cone temperature of $100^{\circ} \mathrm{C}$. The parameters for MS scanning were optimized for the highest signal to 
noise ratio with a synthetic peptide and the mass was calibrated with polyethylene glycol. The average of 20-50 scans (2-5 scan sec ${ }^{-1}$ ) was collected and the spectrum was processed using MassLynx v.3.3 software (Micromass). The sequence of tryptic peptides was deduced from series of $b$ and $y$ ion fragments produced by collision-induced dissociation mass spectrometry (CID-MS/MS). The CID-spectra were submitted directly to MASCOT (http://matrixscience. com) database search against NCBInr.

\section{Results and discussion}

Purification of extracellular $\alpha$-glucosidase and properties

The culture filtrate was applied to a DEAE-Fractogel column and $\alpha$-glucosidase activity was eluted at approximately $0.3 \mathrm{M} \mathrm{NaCl}$. After pooling the fractions containing amylolytic activity, the concentrated sample was applied in a Sephacryl S-200 column equilibrated and eluted as described in "Materials and methods", and this purified $\alpha$-glucosidase pool was used for biochemical studies.

The purified protein migrated as a single polypeptide under 10\% SDS-PAGE (Fig. 1, lane b) and 5\% PAGE (Fig. 1, lanes $\mathrm{c}$ and d). The molecular weight estimated by SDS-PAGE and gel filtration column was 56 and $52 \mathrm{kDa}$, respectively, which is similar to the molecular weight of $54 \mathrm{kDa}$ presented by the monomeric $\alpha$-glucosidase from Paecilomyces lilacinus (Kobayashi et al. 2003). It is noteworthy that gel filtration analysis of dimeric fungal $\alpha$-glucosidases from Mortierella alliacea, Chaetomium thermophilum var. coprophilum and Aspergillus nidulans presented molecular weights of 92, 107 and 129 kDa (Tanaka et al. 2002; Giannesi et al. 2006; Kato et al. 2002). Electrofocusing of the purified $\alpha$ glucosidase of $A$. niveus revealed a $\mathrm{p} I$ of 6.8 , which is similar to value of the $\alpha$-glucosidase from Mortierella alliceae ( $\mathrm{p} I$ 6.3) (Tanaka et al. 2002), in contrast, an $\alpha$-glucosidase from Paecilomyces lilacinus presented a $\mathrm{p} I$ of 9.1 (Kobayashi et al. 2003). The A. niveus $\alpha$-glucosidase is a glycoprotein, and contains $29 \%$ carbohydrate, which is in agreement with other fungal $\alpha$-glucosidases (Giannesi et al. 2006; Yamamoto et al. 2004).

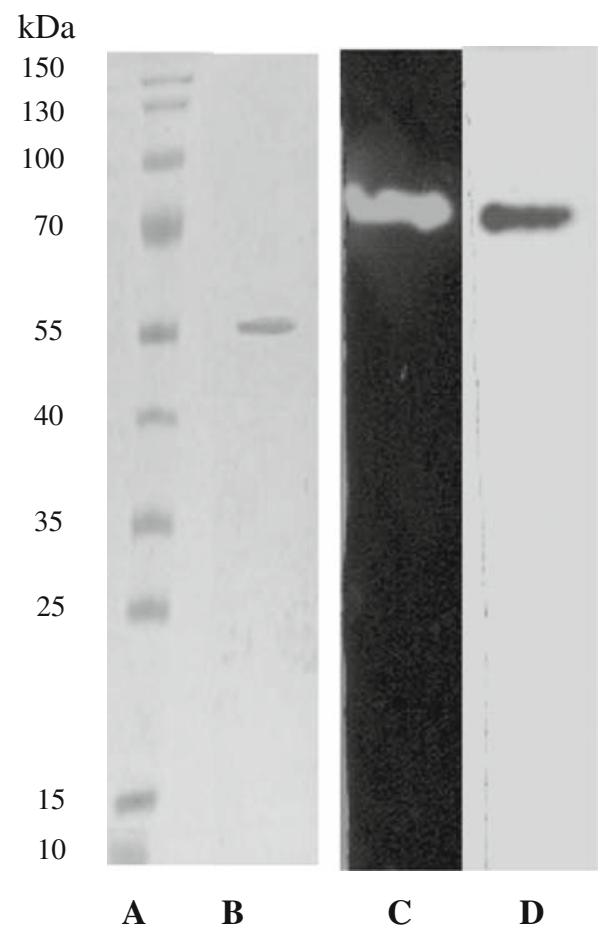

Fig. 1 Electrophoresis analysis of purified $\alpha$-glucosidase: a molecular weight ladder; $\mathbf{b}$ purified $\alpha$-glucosidase in $10 \%$ SDSPAGE; $\mathbf{c}$ developed for glucoamylase activity using iodine; $\mathbf{d}$ $5 \%$ PAGE of the purified $\alpha$-glucosidase revealed with comassie blue

Hydrolysis of different substrates and kinetic parameters

The enzymatic activity of the $\alpha$-glucosidase from Aspergillus niveus against various substrates is presented in Fig. 2. The enzyme hydrolyzed $p$-nitrophenyl $\alpha$-D-glucopyranoside and some polysaccharides, such as amylopectin, starch, glycogen and amylose. Among the malto-oligosaccharides, the enzyme preferentially hydrolyzed malto-oligosaccharide (G10), maltopentaose, maltotetraose, maltotriose and maltose. Isomaltose, trehalose and $\beta$-ciclodextrin were barely hydrolyzed and sucrose and $\alpha$-ciclodextrin were not hydrolyzed.

Apparent kinetic parameters of the purified enzyme were determined using several polysaccharides and maltose. The values obtained (see Table 1) demonstrated that the preferred substrates were glycogen, starch, amylopectin, and amylose, respectively. The $K_{m}$ of $\alpha$-glucosidase from A. niveus against starch is 


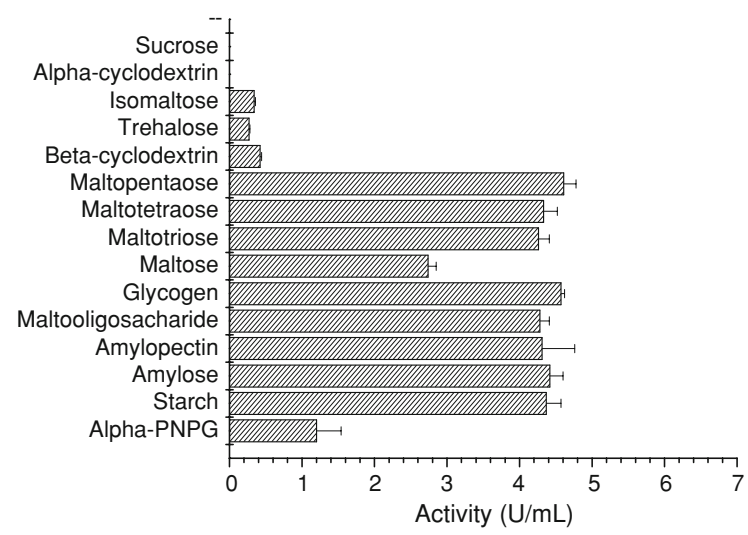

Fig. $2 \alpha$-Glucosidase specific activity on different substrates. The $\alpha$-glucosidase was obtained in Khanna medium after $72 \mathrm{~h}$ of cultivation. Maltooligosaccharide is an oligosaccharide with 10 carbons. The amount of glucose released during $5 \mathrm{~min}$ of reaction was estimated by the peroxidase/glucose oxidase method. When $p$-nitrophenyl- $\alpha$-D-glucopyranoside ( $\alpha$-PNPG) was used as substrate, the activity was measured in a mixture containing $0.2 \mathrm{ml} 0.1 \mathrm{M}$ sodium acetate, $\mathrm{pH} 5.0,0.05 \mathrm{ml}$ of $2 \mathrm{mM}$ substrate solution, and $0.1 \mathrm{ml}$ of enzyme using $5 \mathrm{~min}$ of reaction

lower than that reported to Chaetomium thermophilum var. coprophilum (Giannesi et al. 2006) and Paecilomyces lilacinus (Kobayashi et al. 2003).

The classification of the A. niveus enzyme as an $\alpha$-glucosidase was based both on the hydrolysis of synthetic substrate ( $\alpha$-PNPG), a specific substrate for $\alpha$-glucosidase (Yamamoto et al. 2004; Mackenzie et al. 2000), and the products of starch (see Fig. 3). After $24 \mathrm{~h}$ reaction, only glucose was detected as the reaction product. These results confirm the exoamylolytic character of the enzyme, which was therefore classified as an $\alpha$-glucosidase.

Effect of temperature and $\mathrm{pH}$ on activity and stability

Studies of the temperature and $\mathrm{pH}$ effect on the enzyme activity were carried out over the $45-80^{\circ} \mathrm{C}$ temperature range (in $100 \mathrm{mM}$ sodium acetate buffer, $\mathrm{pH}$ 5.0) and McIlvaine buffer in the range of $\mathrm{pH} 3.0$ 8.0, respectively. Optimum temperature and $\mathrm{pH}$ were estimated to be $65^{\circ} \mathrm{C}$ and 6.0, respectively (Fig. 4a, b). Most of the purified glucosidases from several other sources exhibit $\mathrm{pH}$ optima ranging from 4.5 to 7.0 (Frandsen and Svensson 1998; Yamasaki et al. 1973; Oguma et al. 1992; Giannesi et al. 2006) and temperature optima ranging from 35 to $65^{\circ} \mathrm{C}$ (Kobayashi et al. 2003; Tanaka et al. 2002; Yamamoto et al. 2004; Okuyama et al. 2005). Thermal inactivation by incubating the enzyme in the absence of starch revealed that the purified enzyme was quite stable at $60^{\circ} \mathrm{C}$ (half-life $104 \mathrm{~min}$ ), and decayed with a half-life of approximately $78 \mathrm{~min}$ at $65^{\circ} \mathrm{C}$ (Fig. 4c). The $\alpha$-glucosidase activity of A. niveus was acidalkaline tolerant, remaining stable at $\mathrm{pH} 4.0-8.5$ after $2 \mathrm{~h}$ incubation (Fig. 4d). These results indicate that the enzyme may be appropriate for use in processes that involve extreme conditions.

Influence of metal ions, $\beta$-mercaptoethanol and EDTA

The activities of many fungal amylases are dependent on metallic ions that increase product formation. The $\alpha$-glucosidase activity of $A$. niveus was inhibited by $10 \mathrm{mM} \mathrm{Ag}{ }^{2+}, \mathrm{Fe}^{2+}$ and $\beta$-mercaptoethanol. However, ions, such as $\mathrm{Ca}^{2+}, \mathrm{Ba}^{2+}, \mathrm{Na}^{+}, \mathrm{Mn}^{2+}, \mathrm{Mg}^{2+}$, $\mathrm{Pb}^{2+}, \mathrm{Cu}^{2+}, \mathrm{K}^{+}, \mathrm{Zn}^{2+}$ and EDTA (tested at 1 and $10 \mathrm{mM}$ ) had no effect (data not shown).

Gel in situ trypsin digestion and mass spectrometry analysis

The $\alpha$-glucosidase was subjected to SDS-PAGE electrophoresis and excised gel band was submitted to in situ trypsin digestion followed by mass spectroscopic analysis of the peptide ions. The peptides mass fingerprint showed a series of single and double
Table 1 Kinetic parameters of the $\alpha$-glucosidase from A. niveus

\begin{tabular}{llccc}
\hline Substrate & $K_{m}$ & $V_{\max }\left(\mathrm{U} \mathrm{mg}^{-1}\right.$ protein $)$ & $K_{\text {cat }}\left(\mathrm{s}^{-1}\right)$ & $K_{\text {cat }} / K_{m}\left(\mathrm{~s}^{-1} \mathrm{mg}^{-1} \mathrm{ml}^{-1}\right)$ \\
\hline Starch & $0.07 \mathrm{mg} \mathrm{ml}^{-1}$ & $310.1 \pm 7.2$ & 24.62 & 351.71 \\
Maltose & $0.57 \mathrm{mg} \mathrm{ml}^{-1}$ & $207.7 \pm 4.9$ & 13.66 & 23.96 \\
Amylopectin & $0.11 \mathrm{mg} \mathrm{ml}^{-1}$ & $324.6 \pm 8.5$ & 25.48 & 231.64 \\
Glycogen & $0.04 \mathrm{mg} \mathrm{ml}^{-1}$ & $308.30 \pm 6.3$ & 24.50 & 612.50 \\
$\alpha$-PNPG & $0.55 \mathrm{mM}$ & $8.84 \pm 1.2$ & 0.53 & 0.96 \\
\hline
\end{tabular}




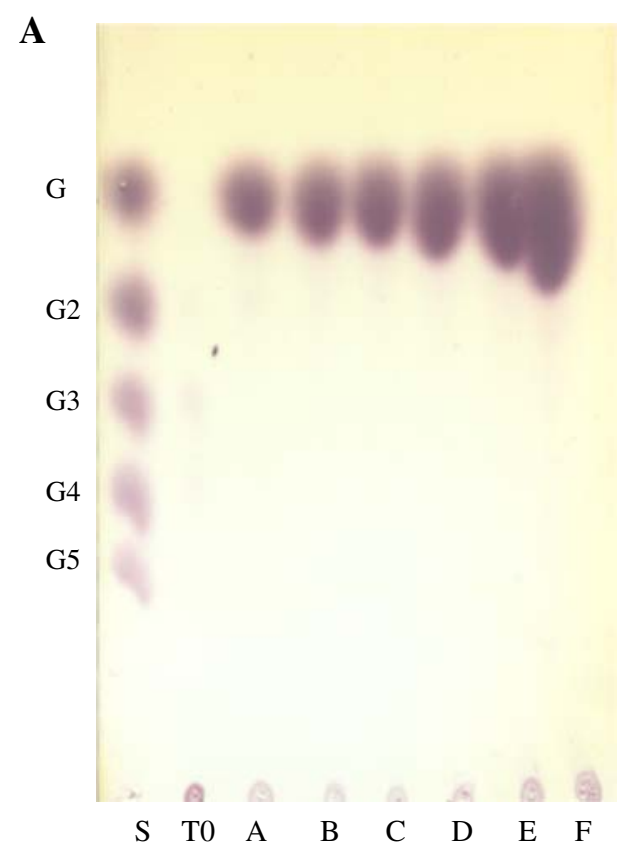

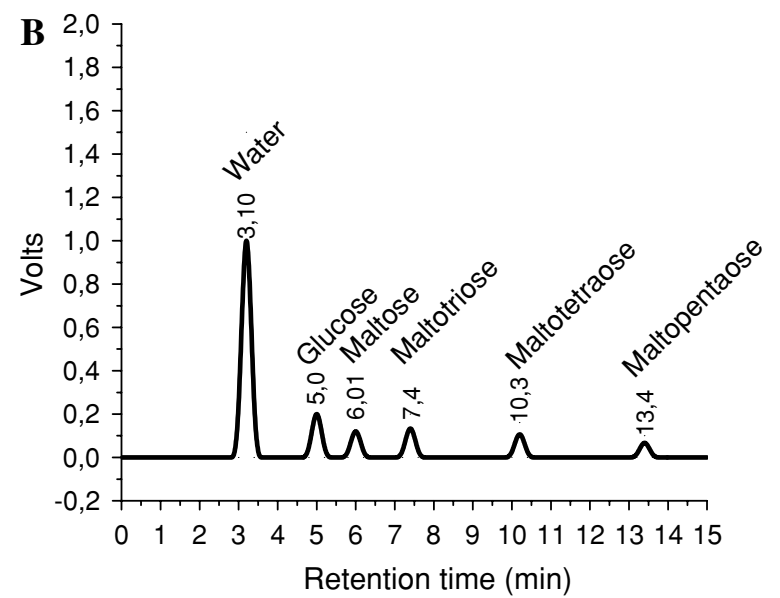

Fig. 3 Analysis of the hydrolysis products from $1 \%$ soluble starch by the purified $\alpha$-glucosidase. a Thin-layer chromatography, $\mathbf{b}$ high performance liquid chromatography of standards and $\mathbf{c}$ hydrolysis products of $A$. niveus $\alpha$-glucosidase. The assay was carried out at $65^{\circ} \mathrm{C}$. Hydrolysis times were 0 (T0), 10 (A),

protonated peptide ions and such peptides ions were also subjected to CID-MS/MS, and the fragment ion masses type $y$ and $b$ obtain from these peptides were compared with the NCBInr database using the algorithm MASCOT (www.matrixscience.com). Table 2 shows the results of mass spectrometry analysis and database search results demonstrated the identity of the peptide amino acid sequences of three tryptic peptides with glucan $\alpha$-1,4-glucosidases from

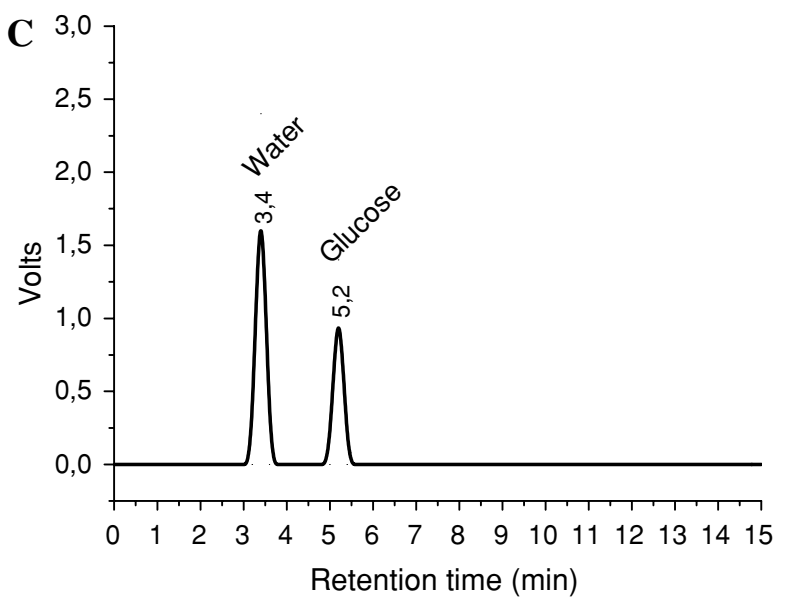

30 (B), 60 (C), $120 \mathrm{~min}$ (D), 12 (E) and 24 h (F). Standards (St) were a mixture of $1 \mathrm{mg} \mathrm{ml}^{-1}$ of glucose $\left(\mathrm{G}_{1}\right)$, maltose $\left(\mathrm{G}_{2}\right)$, maltotriose $\left(\mathrm{G}_{3}\right)$, maltotetraose $\left(\mathrm{G}_{4}\right)$ and maltopentaose $\left(\mathrm{G}_{5}\right)$

Aspergillus fumigatus, Aspergillus nidulans and Neosartorya fischeri. They also are indicated in bold in the Fig. 5.

Amino acid sequence analysis and structural homology database searches

In addition to the similarity between the $\alpha$-glucosidases from A. fumigatus and A. niveus, 54\% identity 

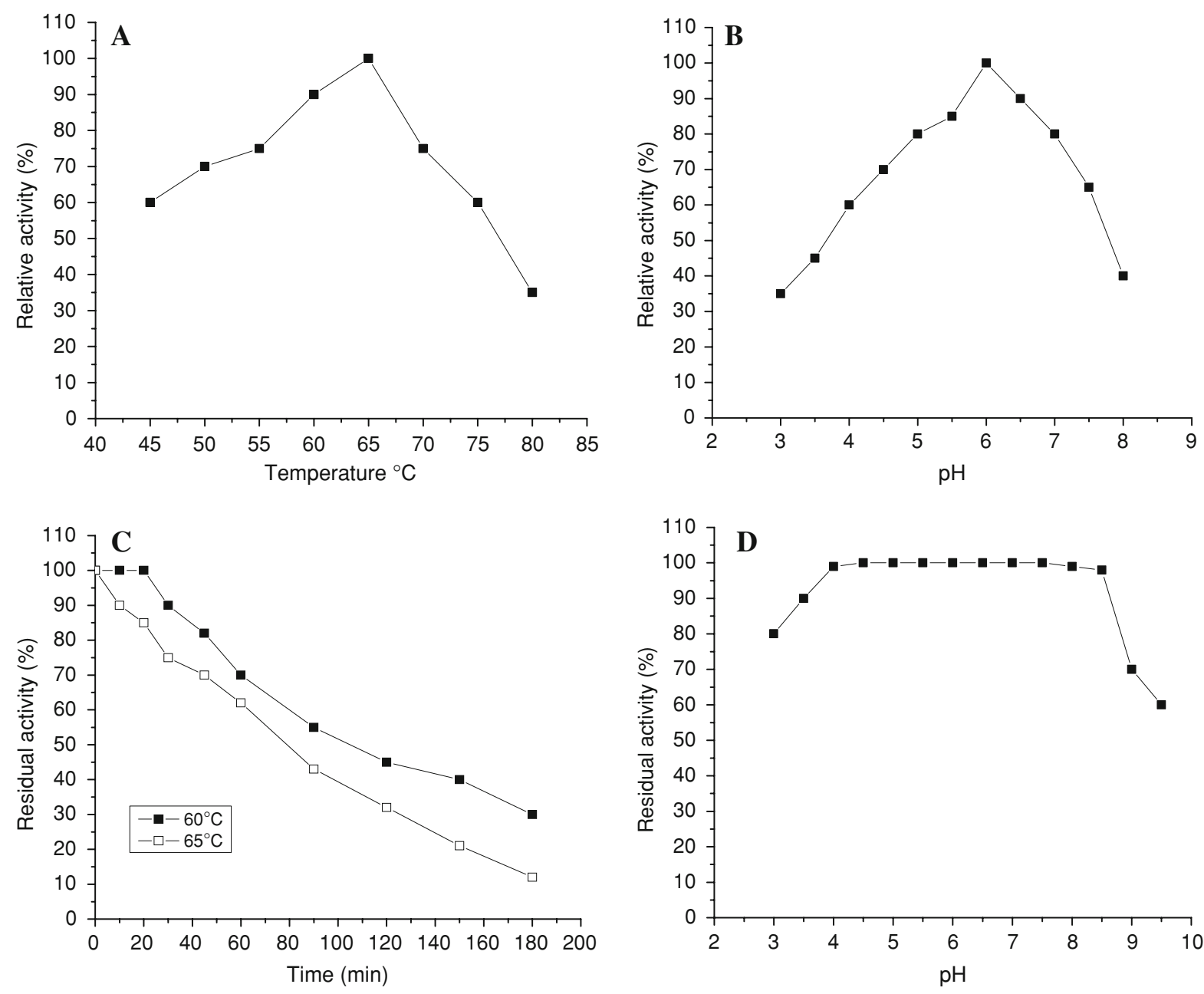

Fig. 4 Effect of temperature and $\mathrm{pH}$ in $\alpha$-glucosidase activity and stability. a Temperature optimal, b pH optimal, c stability at 60 and $65^{\circ} \mathrm{C}$ and $\mathbf{d ~} \mathrm{pH}$ stability. The $\alpha$-glucosidase was

obtained in Khanna medium with $72 \mathrm{~h}$ of cultivation. The activity assay was carried out as in "Materials and methods", modifying $\mathrm{pH}$ and temperature in according to each experiment

Table 2 Mass spectrometry analysis of peptides generated by trypsin digestion of the $\alpha$-glucosidase from A. niveus

\begin{tabular}{llllll}
\hline $\mathrm{M}+2 \mathrm{H}^{+}$ & $\mathrm{M}+\mathrm{H}^{+}$ & $\mathrm{Mr}$ (expected) & Mr (calculated) & Delta & Peptide sequencing \\
\hline 511.8 & 1022.6 & 1021.5 & 1021.6 & 0.1 & ALVEGSTFAK \\
786.5 & 1572.0 & 1570.9 & 1571.0 & 0.1 & IGSISITSTSLAFFK \\
909.5 & 1818.0 & 1816.9 & 1817.0 & 0.1 & SVYAINSGIPQGAAVSAGR
\end{tabular}

Note: Double protonated ions were de-convoluted to single protonated ions using MaxEnt3 algorithm and CID-MS/MS espectra were converted to sequest file.dta (MassLynx v. 3.3) and they were submitted to database search using MASCOT (www.matrixscience.com) against the NCBI non redundant database

was detected between the sequences of $\alpha$-glucosidases from A. fumigatus and the family 15 glycoside hydrolase from the filamentous fungus Hypocrea jecorina (Trichoderma reesei). Figure 5 shows the amino acid sequence alignment of the A. fumigatus and the $H$. jecorina enzymes, in which the peptides from the A. niveus $\alpha$-glucosidase identified by mass spectrometry indicated in bold. The sequence 
Fig. 5 Amino acid sequence alignment of the $\alpha$-glucosidases from Aspergillus fumigatus and Hypocrea jecorina. The protein $\alpha$-glucosidase from A. niveus was identified by mass spectrometry using the amino acid sequences of tryptic peptides listed in Table 2 and they are indicated in bold
A. fumigatus H. jecorina

A. fumigatus H. jecorina

A. fumigatus H. jecorina

A. fumigatus H. jecorina

A. fumigatus H. jecorina

A. fumigatus H. jecorina

A. fumigatus H. jecorina

A. fumigatus H. jecorina

A. fumigatus H. jecorina

A. fumigatus H. jecorina

A. fumigatus H. jecorina

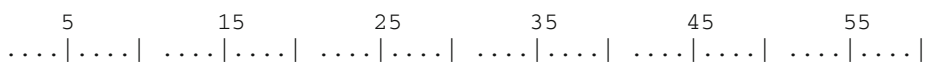
MPRLSYALCA LSLGHAAIAA PQLSARATGS LDSWLGTETT VALNGILANI GADGAYAKSA ------- ------- ------S VDDFISTETP IALNNLLCNV GPDGCRAFGT

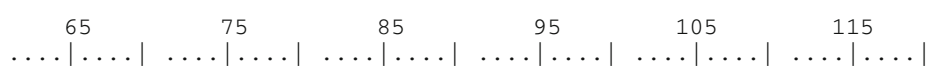
KPGIIIASPS TSEPDYYYTW TRDAALVTKV LVDLFRNG-N LGLQKVITEY VNSQAYLQTV SAGAVIASPS TIDPDYYYMW TRDSALVFKN LIDRFTETYD AGLQRRIEQY ITAQVTLQGL

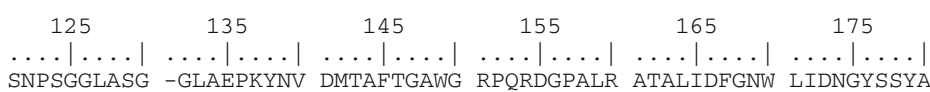
SNPSGGLASG -GLAEPKYNV DMTAFTGAWG RPQRDGPALR ATALIDFGNW LIDNGYSSYA
SNPSGSLADG SGLGEPKFEL TLKPFTGNWG RPORDGPALR AIALIGYSKW LINNNYOSTV 185
$\ldots$ 295 VNNIWPIVRN DLSYVSQYWS QSGFDLWEEV NSMSFFTVAV QHRALVEGST FAKRVGASCS SNVIWPIVRN DLNYVAQYWN QTGFDLWEEV NGSSFFTVAN QHRALVEGAT LAATLGQSGS

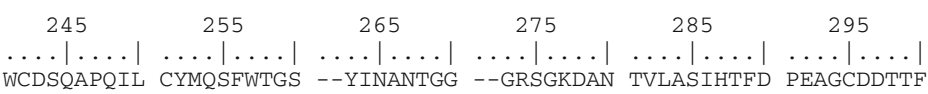
AYSSVAPQVL CFLQRFWVSS GGYVDSNINT NEGRTGKDVN SVLTSIHTFD PNLGCDAGTF

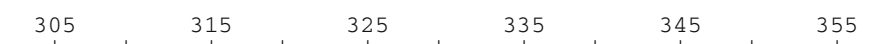

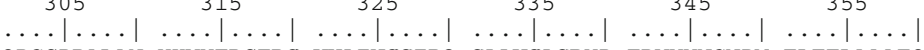
QPCSPRALAN HKVYTDSFRS VYAINSGIPQ GAAVSAGRYP EDVYYNGNPW FLTTLAAAEQ QPCSDKALSN LKVVVDSFRS IYGVNKGIPA GAAVAIGRYA EDVYYNGNPW YLATFAAAEQ

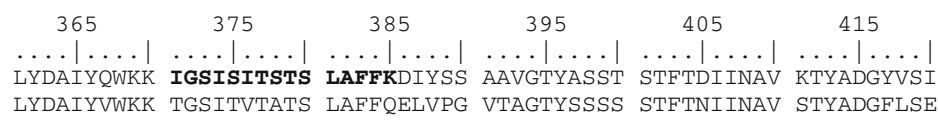

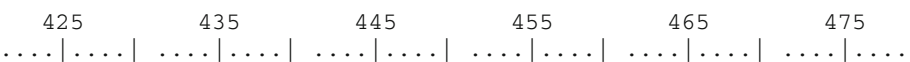
VQAHAMNNGS LSEQFDKSSG LSLSARDLTW SYAAFLTANM RRNGVVPAPW GAASANSVPS AAKYVPADGS LAEQFDRNSG TPLSALHLTW SYASFLTATA RRAGIVPPSW ANSSASTIPS

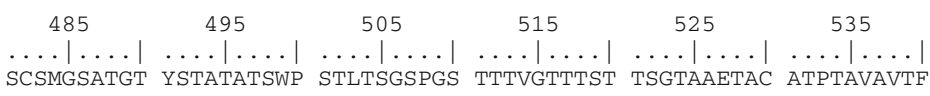
TCSGASVVGS YSRPTATSFP PSQTP-KPG- -VPSGTPYTP LP------C ATPTSVAVTF

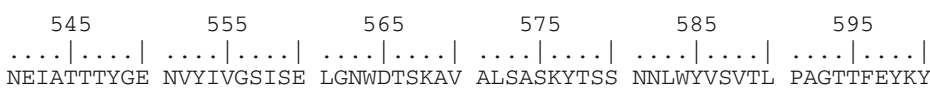
NEIATTTYGE NVYIVGSISE LGNWDTSKAV ALSASKYTSS NNLWYVSVTL PAGTTFEYKY
HELVSTQFGQ TVKVAGNAAA LGNWSTSAAV ALDAVNYADN HPLWIATVNL EAGDVVEYKY

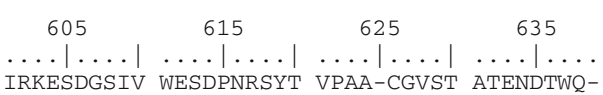
IRKESDGSIV WESDPNRSYT VPAA-CGVST ATENDTWQ-
INVGQDGSVT WESDPNHTYT VPAVAC-VTQ VVKEDTWQS comparison reveals that the residues $1-19$ encode a signal peptide, residues 20-522 show high similarity with enzymes of the family 15 of the glycosyl hydrolase, and residues 523-638 show similarity with the family 20 carbohydrate binding motif (CBM20 domain). The three-dimensional structure of the $H$. jecorina enzyme (PDB code 2VN4) (Bott et al. 2008) reveals that the family 15 domain of the glycosyl hydrolase is rich in $\alpha$-helical structure, whereas the CDM domain is comprised exclusively of beta-sheet. Analysis of the three-dimensional structures of the two domains reveals a total $\alpha$-helical content of $31 \%$ and a total beta-sheet content of $15 \%$.

\section{Circular dichroism analysis}

The circular dichroism spectra of the $\alpha$-glucosidase from $A$. niveus was measured over the wavelength range of 190-250 nm (see Fig. 6), and reveals distinct minima at 209 and $222 \mathrm{~nm}$, with a maximum at $194 \mathrm{~nm}$, which are typical spectral features for a protein that is rich in $\alpha$-helices. Analysis of the CD spectrum using the K2D algorithm (Andrade et al. 1993) predicts an $\alpha$-helical content of $31 \%$ and a betasheet content of $16 \%$, which is in enzyme excellent agreement with the values derived from the crystal structure of the homologous $H$. jecorina enzyme. In 


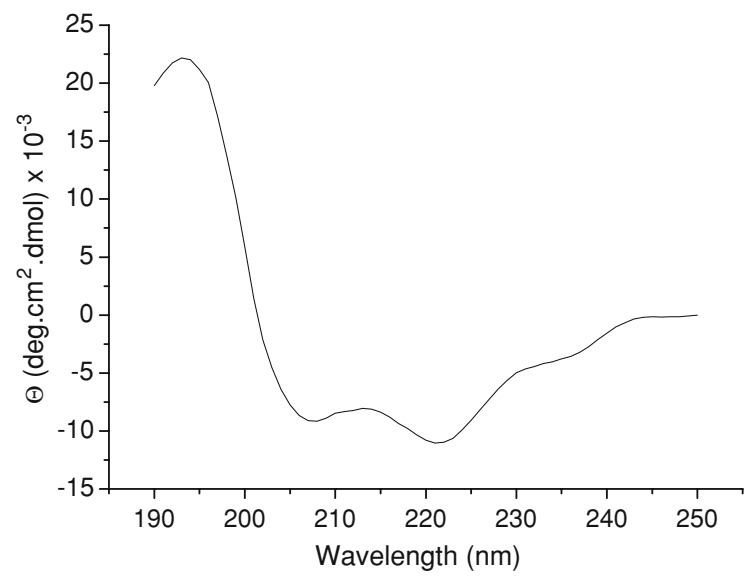

Fig. 6 Far-UV CD spectra of the glucoamylase purified from A. niveus. The molar ellipticity $(\Theta)$ was calculated assuming which the A. niveus Table -glucosidase presents a similar number of amino-acid residues as the $\alpha$-glucosidases from other Aspergillus species. See "Materials and methods" for further experimental details

addition to the major peaks at 194, 209 and $222 \mathrm{~nm}$, Fig. 6 shows that a weak signal is observed between 225 and $240 \mathrm{~nm}$. Although the far-ultraviolet circular dichroism spectra is dominated by the electronic and magnetic transitions of electrons in the main chain peptide bonds, the $\mathrm{CD}$ spectrum in this region also contains contributions from amino acid side-chains. These signals may arise from coupled electronic transitions in the B-band of aromatic amino acid sidechains that are in close proximity to each other in the protein structure. Analysis of the crystal structure of the family 15 glycoside hydrolase from $H$. jecorina reveals contacts between the indole side chains of tryptophan 51 and 120, tryptophan 525 and 572, and a cluster comprised of tryptophans 178, 321 and 421, which supports the interpretation that the observed signal in the ultraviolet region of the CD spectra may arise from these residues.

\section{Conclusion}

Here we have described the purification and biochemical characterization of an $\alpha$-glucosidase from Aspergillus niveus. The catalytic properties suggest the enzyme as a tool for industrial applications, where the optimum enzymatic activity at $50-60^{\circ} \mathrm{C}$ and $\mathrm{pH}$ near to neutral is preferred. This enzyme efficiently hydrolyzed starch, glycogen, amylose, amylopectin and malto-oligosaccharide (G10). The low hydrolytic activity against aryl glucosides and maltose discards the possibility that this enzyme belongs to the types I, II and III as described in the literature. The similar capacity of hydrolyzing starch, glycogen and maltooligosaccharide (G10), as well the non capacity of hydrolyzing the sucrose, suggesting that this enzyme constituted a new type of $\alpha$-glucosidase.

Acknowledgments This work was supported by Fundação de Amparo à Pesquisa do Estado de São Paulo (FAPESP) and Conselho de Desenvolvimento Científico e Tecnológico (CNPq). J. A. J.; H. F. T.; R. J. W. and M. L. T. M. P. are CNPq Research Fellows. T. M. Silva was a recipient FAPESP Fellowship and this work was part of the Doctor Thesis. We thank Ricardo Alarcon and Mauricio de Oliveira for technical assistance.

\section{References}

Andrade MA, Chacon P, Merelo JJ, Moran F (1993) Evaluation of secondary structure of proteins from UV circular dichroism spectra using an unsupervised learning neural network. Protein Eng 6:383-390

Bott R, Saldajeno M, Cuevas W, Ward D, Scheffers M, Aehle W, Karkehabadi S, Sandgren M, Hansson H (2008) Threedimensional structure of an intact glycoside hydrolase family 15 glucoamylase from Hypocrea jecorina. Biochemistry 47:5746-5754

Cereia M, Terenzi HF, Jorge JA, Greene LJ, Rosa JC, Polizeli MLTM (2000) Glucoamylase activity from the thermophilic fungus Scytalidium thermophilum. Biochemical and regulatory properties. J Basic Microbiol 40(2):83-92

Davis BJ (1964) Disc electrophoresis. II. Methods and application to human serum proteins. Ann NY Acad Sci 121: 404-427

Dubois M, Gilles KA, Hamilton JK, Rebers PA, Smith F (1956) Colorimetric method for determination of sugars and related substances. Anal Chem 28:350-356

Fontana JD, Gebara M, Blumel M, Schneider H, Mackenzie CR, Johnson KG (1988) $\alpha$-4-O-methyl-D-glucuronidase component of xylanolytic complexes. Methods Enzymol 160:560-571

Frandsen TP, Svensson B (1998) Plant $\alpha$-glucosidase of the glycoside hydrolase family 31. Molecular properties, substrate specificity, reaction mechanism, and comparison with family members of different origin. Plant Mol Biol 27:1-13

Giannesi GC, Polizeli MLTM, Terenzi HF, Jorge JA (2006) A novel $\alpha$-glucosidase from Chaetomium thermophilum var. coprophilum that converts maltose into trehalose: purification and partial characterization of the enzyme. Process Biochem 41:1729-1735

Hanes CS (1932) The effect of starch concentration upon the velocity of hydrolysis by the amylase of germinated barley. Biochem J 26:1406-1421

Kato N, Suyama S, Shirokane M, Kato M, Kobayashi T, Tsukagoshi N (2002) Novel $\alpha$-glucosidase from 
Aspergillus nidulans with strong transglycosylation activity. Appl Environ Microbiol 68:1250-1256

Khanna P, Sundari SS, Kumar NJ (1995) Production, isolation and partial purification of xylanase from Aspergillus sp. World J Microbiol Biotechnol 11:242-243

Kobayashi I, Tokuda M, Hashimoto H, Konda T, Nakano H, Kitahata S (2003) Purification and characterization of a new type of $\alpha$-glucosidase from Paecilomyces lilacinus that has transglucosylation activity to produce $\alpha-1,3-$ and $\alpha$-1,2-linked oligosaccharides. Biosci Biotechnol Biochem 67:29-35

Laemmli UK (1970) Cleavage of structural proteins during the assembly of head of bacteriophage T4. Nature 227: 680-685

Lowry OH, Rosebrough NJ, Farr AL, Randall RJ (1951) Protein measurement with the Folin phenol reagent. J Biol Chem 193:267-275

MacKenzie DA, Jeenes DJ, Gou X, Archer DB (2000) Molecular basis of glucoamylases overproduction by a mutagenised industrial strain of Aspergillus niger. Enzyme Microb Technol 26:193-200

Marín D, Linde D, Lobato MF (2006) Purification and biochemical characterization of an $\alpha$-glucosidase from Xanthophyllomyces dendrorhus. Yeast 23:117-125

Maruta K, Nakda T, Kubata M, Chaen H, Sugimoto T, Kurimoto M (1995) Formation of trehalase from maltooligosaccharides by a novel enzymatic system. Biosci Biotechnol Biochem 56:1829-1834

Michelin M, Ruller R, Ward RJ, Moraes LAB, Jorge JA, Terenzi HF, Polizeli MLTM (2008) Purification and biochemical characterization of a thermostable extracellular glucoamylase produced by the thermotolerant fungus Paecilomyces variotii. J Ind Microbiol Biotechnol 35:17-25
Miller GL (1959) Use of dinitrosalicylic acid reagent for determination of reducing sugar. Anal Chem 31:426-489

Nishimoto T, Nakano M, Ikegami S, Chaen H, Fukuda S, Sugimoto T (1995) Existence of a novel enzyme converting maltose into trehalose. Biosci Biotechnol Biochem 59:2189-2190

O'Farrel PZ, Goodman HM, O'Farrel PH (1977) High resolution two dimensional electrophoresis of basic as well as acidic proteins. Cell 12:1133-1142

Oguma T, Matsui H, Tanida M, Takao S, Honma M, Chiba S (1992) Purification and substrate specificity of a $\alpha$-glucosidase from Paecilomyces variotii AHU. Biosci Biotechnol Biochem 56:1906-1910

Okuyama M, Tanimoto Y, Ito T, Anzai A, Mori H, Kimura A (2005) Purification and characterization of the hyperglycosylated extracellular $\alpha$-glucosidase from Schizosaccharomyces pombe. Enzyme Microb Technol 37:472-480

Pandey A, Nigam P, Soccol CR, Soccol VT, Singh DRM (2000) Advances in microbial amylases. Review. Biotechnol Appl Biochem 31:135-152

Tanaka Y, Aki T, Hidaka Y, Furuya Y, Kawamoto S, Shigeta S, Ono K, Suzuki O (2002) Purification and characterization of a novel fungal $\alpha$-glucosidase from Mortirella alliacea with high starch-hydrolytic activity. Biosci Biotechnol Biochem 66:2415-2423

Yamamoto T, Unno T, Watanabe Y, Yamamoto M, Okuyama M, Mori H, Chiba S, Kimura A (2004) Purification and characterization of Acremonium implicatum $\alpha$-glucosidase having regioselectivity for $\alpha$-1,3-glucosidic linkage. Biochim Biophys Acta 1700(2):189-198

Yamasaki Y, Miyake T, Suzuki Y (1973) Properties of crystalline $\alpha$-glucosidase from Mucor javanicus. Agric Biol Chem 37:251-259 


\title{
Properties of a purified thermostable glucoamylase from Aspergillus niveus
}

\author{
Tony Marcio da Silva • Alexandre Maller • André Ricardo de Lima Damásio • \\ Michele Michelin · Richard John Ward · Izaura Yoshico Hirata · João Atilio Jorge • \\ Héctor Francisco Terenzi • Maria Lourdes T. M. de Polizeli
}

Received: 30 January 2009 / Accepted: 30 July 2009

(C) Society for Industrial Microbiology 2009

\begin{abstract}
A glucoamylase from Aspergillus niveus was produced by submerged fermentation in Khanna medium, initial $\mathrm{pH} 6.5$ for $72 \mathrm{~h}$, at $40^{\circ} \mathrm{C}$. The enzyme was purified by DEAE-Fractogel and Concanavalin A-Sepharose chromatography. The enzyme showed $11 \%$ carbohydrate content, an isoelectric point of 3.8 and a molecular mass of 77 and $76 \mathrm{kDa}$ estimated by sodium dodecyl sulfate-polyacrylamide gel electrophoresis or Bio-Sil-Sec-400 gel filtration, respectively. The $\mathrm{pH}$ optimum was 5.0-5.5, and the enzyme remained stable for at least $2 \mathrm{~h}$ in the $\mathrm{pH}$ range of 4.0-9.5. The temperature optimum was $65^{\circ} \mathrm{C}$ and retained $100 \%$ activity after $240 \mathrm{~min}$ at $60^{\circ} \mathrm{C}$. The glucoamylase remained completely active in the presence of $10 \%$ methanol and acetone. After 120 min hydrolysis of starch, glucose was the unique product formed, confirming that the enzyme was a glucoamylase (1,4-alpha-D-glucan
\end{abstract}

T. M. da Silva $\cdot$ M. Michelin $\cdot$ J. A. Jorge $\cdot$ H. F. Terenzi

M. L. T. M. de Polizeli ( $\varangle$ )

Departamento de Biologia, Faculdade de Filosofia Ciências e Letras de Ribeirão Preto, Universidade de São Paulo,

Av. Bandeirantes 3900, Monte Alegre,

14040-901 Ribeirão Preto, São Paulo, Brazil

e-mail: polizeli@ffclrp.usp.br

A. Maller · A. R. de Lima Damásio

Departamento de Bioquímica e Imunologia, FMRP,

Universidade de São Paulo, Ribeirão Preto, São Paulo, Brazil

R. J. Ward

Departamento de Química, FFCLRP, Universidade de São Paulo, Ribeirão Preto, São Paulo, Brazil

I. Y. Hirata

Departamento de Biofísica, Universidade Federal de São Paulo,

São Paulo, SP, Brazil glucohydrolase). The $K_{\mathrm{m}}$ was calculated as $0.32 \mathrm{mg} \mathrm{ml}^{-1}$. Circular dichroism spectroscopy estimated a secondary structure content of 33\% $\alpha$-helix, 17\% $\beta$-sheet and 50\% random structure, which is similar to that observed in the crystal structures of glucoamylases from other Aspergillus species. The tryptic peptide sequence analysis showed similarity with glucoamylases from A. niger, A. kawachi, A. ficcum, A. terreus, A. awamori and A. shirousami. We conclude that the reported properties, such as solvent, $\mathrm{pH}$ and temperature stabilities, make A. niveus glucoamylase a potentially attractive enzyme for biotechnological applications.

Keywords Glucoamylase - Fungi · Thermostability · Organic solvents $\cdot$ Aspergillus niveus

\section{Introduction}

Amylases are enzymes present in many organisms. In plants they participate in the synthesis of starch in some types of roots and in animals for the digestion of starch in food, and are found in many prokaryotic and eukaryotic microbes that use starch as a carbon source [28]. Glucoamylases hydrolyze $\alpha-1,4$ and $\alpha-1,6$ linkages of starch and related polymers to produce glucose as the sole end product. Glucoamylases also hydrolyze other starchrelated oligo- and polysaccharides, and show a preference for maltooligosaccharides of at least six residues [22]. One of most important applications of glucoamylases is the production of high glucose syrups from starch, and these enzymes are also used in the production of ethanol and in the baking and brewing industries [35].

Industrial applications require enzymes with high activity and thermostability, and for the starch processing 
industry there are many advantages of using thermostable enzymes, such as an increased reaction rate and decreased contamination risk through the use of high temperatures $[14,15]$. Several microbial strains are known sources of glucoamylase production, and several species of Aspergillus and Rhizopus have been widely used for commercial production $[12,33]$.

Enzymes with high stability and activity in the presence of organic solvents would be useful for biotechnological applications in which these solvents are used. Organicsolvent-tolerant prokaryotic microorganisms have been studied [7, 8, 10, 26, 27]; however, fungal enzymes with stability and activity in the presence of organic solvents have not yet been reported. The aim of this work was to describe biochemical properties of a glucoamylase purified from the thermotolerant filamentous fungus A. niveus, which presents high amylolytic activity in the presence of organic solvents and elevated thermostability.

\section{Materials and methods}

Microorganism and growth conditions

Aspergillus niveus was isolated from Mangifera indica in our laboratory. The microorganism was identified and deposited in the culture collection of the University Recife Mycology-URM (PE, Brazil), WFCC, number 604. The organism was maintained on slants of PDA medium covered with mineral oil and stored at $4{ }^{\circ} \mathrm{C}$. Approximately $10^{7}$ conidia/ml from 3-day-old cultures were inoculated into $125-\mathrm{ml}$ Erlenmeyer flasks containing $25 \mathrm{ml}$ of modified Khanna medium [16] $(0.1 \%$ yeast extract, $5 \%$ Khanna salt solution $(2 \%$ $\mathrm{NH}_{4} \mathrm{NO}_{3}, 1.3 \% \mathrm{KH}_{2} \mathrm{PO}_{4}, 0.36 \% \mathrm{MgSO}_{4} \cdot 7 \mathrm{H}_{2} \mathrm{O}, 0.1 \% \mathrm{KCl}$, $0.07 \% \quad \mathrm{ZnSO}_{4} \cdot \mathrm{H}_{2} \mathrm{O}, \quad 0.014 \% \quad \mathrm{MnSO}_{4} \cdot \mathrm{H}_{2} \mathrm{O}, \quad 0.007 \%$ $\left.\mathrm{Fe}_{2}\left(\mathrm{SO}_{4}\right)_{3} \cdot 6 \mathrm{H}_{2} \mathrm{O}, 0.006 \% \mathrm{CuSO}_{4} \cdot 5 \mathrm{H}_{2} \mathrm{O}\right)$ and $1 \%$ starch. After inoculation, the cultures were maintained at $40^{\circ} \mathrm{C}$ for $72 \mathrm{~h}$ under static conditions at an initial $\mathrm{pH}$ 6.5. After filtration of the culture in a Büchner funnel and filter paper Whatman ${ }^{\circledR}$ no. 1 , the filtrate was used as a source of crude extracellular amylolytic activity.

Determination of amylase activity

The activity of glucoamylase was routinely assayed with $1 \%$ soluble commercial starch in $100 \mathrm{mM}$ sodium acetate buffer, $\mathrm{pH}$ 5.0, and the released reducing sugar was determined by the Miller method [24]. One enzyme unit was defined as the amount that releases reducing sugar at an initial rate of $1 \mu \mathrm{mol} \mathrm{min}{ }^{-1}$ at the temperature optimum of the enzyme (in this case $65^{\circ} \mathrm{C}$, see "Results and discussion"). Extracellular protein was determined by the Lowry method [21] using bovine serum albumin as standard.
PAGE of purified glucoamylase

The purified sample was applied in 6\% PAGE [5], after the gel was incubated in $500 \mathrm{mM}$ sodium acetate buffer, $\mathrm{pH}$ 5.0 , for $1 \mathrm{~h}$, at $4^{\circ} \mathrm{C}$ for determination of the glucoamylase activity. The gel was subsequently immersed in $1 \%$ starch solution for $30 \mathrm{~min}$ at $60^{\circ} \mathrm{C}$ and developed with $0.1 \%$ $\mathrm{I}_{2}+1.5 \% \mathrm{KI}$. In parallel, a separate gel was run under identical conditions and developed with $\mathrm{AgNO}_{3}$ for protein visualization.

\section{Glucoamylase purification}

All steps were carried out at $4{ }^{\circ} \mathrm{C}$. The crude enzyme extract was applied to a DEAE-Fractogel TSK $650 \mathrm{M}$ column $(2.0 \times 7.0 \mathrm{~cm})$ previously equilibrated in $10 \mathrm{mM}$ Tris- $\mathrm{HCl}$ buffer $\mathrm{pH} 7.5$ and eluted at a flow rate of $100 \mathrm{ml} / \mathrm{h}$. Fractions of $10 \mathrm{ml}$ were collected and assayed for enzyme activity. The pool showing amylase activity was applied to a Concanavalin A-Sepharose affinity chromatographic column $(1.2 \times 5.0 \mathrm{~cm})$, and a $1-\mathrm{ml}$ fraction was collected. The glucoamylase was eluted with a linear gradient of methyl $\alpha$-D-mannopyranoside $(0-0.3 \mathrm{M}, 50 \mathrm{ml})$ in Tris- $\mathrm{HCl}$ buffer containing $500 \mathrm{mM} \mathrm{NaCl}, 0.5 \mathrm{mM} \mathrm{MnCl}_{2}$ and $0.5 \mathrm{mM}$ $\mathrm{CaCl}_{2}$, at a flow rate of $36 \mathrm{ml} / \mathrm{h}$. Protein elution was monitored by measurement of absorbance at $280 \mathrm{~nm}$.

SDS-PAGE of purified glucoamylase

Protein homogeneity and the molecular mass of the enzyme were evaluated by $6 \%$ sodium dodecyl sulfate-polyacrylamide gel electrophoresis (SDS-PAGE) as described previously by Laemmli [18]. Gels were stained with $0.25 \%$ Coomassie Brilliant Blue R-250 and destained with methanol-acetic acid-water (3:1:6). Molecular mass markers were: myosin $(205 \mathrm{kDa})$, phosphorylase $(97 \mathrm{kDa})$, bovine serum albumin $(66 \mathrm{kDa})$ and ovalbumin $(45 \mathrm{kDa})$.

\section{Deglycosylation assay}

Deglycosylation of the glucoamylase was performed using the enzymes Endo $\mathrm{H}$ (Endo- $\beta$ - $N$-acetilglucosaminidase $\mathrm{H}$; EC 3.2.1.96) from Streptomyces plicatus or PNGase F (Peptide- $N$-glycosidase F; EC 3.2.1.18) from Flavobacterium meningosepticum. One unit of each enzyme was used to deglycosylate $50 \mu \mathrm{g}$ of purified glucoamylase at $37^{\circ} \mathrm{C}$ for $48 \mathrm{~h}$. Samples were analyzed by SDS-PAGE.

\section{Enzymatic characterization}

The $\mathrm{pH}$ optimum was determined at $60^{\circ} \mathrm{C}$ using citratephosphate buffer ( $\mathrm{pH}$ range 3.0-7.0). The $\mathrm{pH}$ stability was determined at $30^{\circ} \mathrm{C}$, for $2 \mathrm{~h}$, after pre-incubation of the 
diluted enzyme in citrate phosphate buffer at different $\mathrm{pH}$ values (pH range 3.0-9.0). The temperature optimum was determined with $0.1 \mathrm{M}$ sodium acetate buffer, $\mathrm{pH}$ 5.5. The thermostability was determined by measuring the residual activity after incubation of the diluted enzyme in the absence of substrate at $60^{\circ} \mathrm{C}$ in $0.1 \mathrm{M}$ sodium acetate buffer, $\mathrm{pH} 5.0$, for $6 \mathrm{~h}$. For determination of the $\mathrm{pH}$ and temperature stabilities, the enzymatic assays were carried out using $1 \%$ soluble starch as substrate. For the determination of the effect of metallic ions on glucoamylase activity, assays were performed in 1 or $10 \mathrm{mM}$ final concentration of metallic ions, where the activity in the absence of metallic ions was defined as the control. For determination of the effect of organic solvents, the enzymatic assay was performed after pre-incubating the enzyme with 5 or $10 \%$ final concentration of solvents. The activity assayed in the absence of solvents was defined as the control. The $K_{\mathrm{m}}$ and $V_{\max }$ values for the purified enzyme were determined by incubating the enzyme with $0-300 \mathrm{mg}$ soluble starch in $100 \mathrm{mM}$ sodium acetate buffer, $\mathrm{pH} 5.5$, at $65^{\circ} \mathrm{C}$. The data obtained were fitted to a standard Hanes model using linear regression [20].

\section{Identification of hydrolysis products}

The hydrolysis products of the amylase activity against soluble $1 \%$ starch as substrate were analyzed by thin-layer chromatography. The mobile phase was butanol/ethanol/ water (5:3:2). Sugars were determined with $0.2 \%$ orcinol in a 9:1 methanol-sulfuric acid mixture [4]. Glucose, maltose, maltotriose, maltotetraose and maltopentaose were used as standards.

Dichroism circular and amino acid sequence analysis

Circular dichroism measurements were performed in $20 \mathrm{mM}$ HEPES $\mathrm{pH} 7.0$, at $25^{\circ} \mathrm{C}$. Far ultraviolet circular dichroism spectra $(190-250 \mathrm{~nm})$ were measured with a JASCO 810 (JASCO Inc., Tokyo, Japan) using 1-mm path length cuvettes and a protein concentration of $150 \mu \mathrm{g} / \mathrm{ml}$ protein. A total of nine spectra were collected, averaged and corrected by subtraction of a buffer blank. The secondary structure content of the protein was estimated using the program K2D [3] as implemented in the DicroProt suite of programs [6]. Molar ellipticity calculations assumed that the protein shares high sequence similarity with the glucoamylases from other Aspergillus species and therefore is comprised of 614 amino acids. The tryptic amino acid sequence analysis of purified glucoamylase was made using the automatic sequencing machine PPSQ/23 (Shimadzu Corp., Tokyo, Japan) with isocratic system HPLC. The information obtained served as the basis for comparison with glucoamylases of other species of the genus Aspergillus.

\section{Results and discussion}

Purification of the amylolytic enzyme

Glucoamylase from culture filtrate was purified by two chromatographic steps (Table 1). Crude filtrate $(150 \mathrm{ml})$ containing the glucoamylase was applied to a DEAEFractogel column equilibrated with $10 \mathrm{mM}$ Tris- $\mathrm{HCl}$ buffer, $\mathrm{pH} 7.5$, and the enzyme activity was eluted in the same buffer. This initial step resulted in the exclusion of approximately $42 \%$ of protein contaminants from the crude filtrate. The eluted fractions containing the amylase activity were pooled and applied to a Concanavalin A-Sepharose affinity column, and amylolytic activity was eluted with a linear gradient of $(0-0.3 \mathrm{M})$ methyl $\alpha$-D-mannopyranoside, resulting in a 2.53 -fold purification with a recovery of $52 \%$. The purification protocol resulted in a single band with amylolytic activity on solubilized starch PAGE, and a single protein band was observed with SDS-PAGE (Fig. 1a, b, lanes 1-3, respectively).

Biochemical characterization

The molecular mass of the purified glucoamylase was $77 \mathrm{kDa}$ by SDS-PAGE and $76 \mathrm{kDa}$ by gel filtration on Bio-Sil-Sec-400 (Bio Rad). The purified enzyme bound to Concanavalin A Sepharose, suggesting that it was a glycoprotein with a sugar content of approximately $11 \%$. After PNGase $F$ treatment, the mobility of protein was modified on SDS-PAGE, demonstrating a molecular mass of $68 \mathrm{kDa}$ (Fig. 1b, lane 3). The carbohydrate moiety in some glycoproteins produced by filamentous fungi is responsible by

Table 1 Purification of extracellular glucoamylase from Aspergillus niveus

\begin{tabular}{llllcc}
\hline Step & $\begin{array}{l}\text { Protein } \\
\text { (total mg) }\end{array}$ & $\begin{array}{l}\text { Activity } \\
\text { (total U) }\end{array}$ & $\begin{array}{l}\text { Specific activity } \\
\text { (U/mg protein) }\end{array}$ & $\begin{array}{l}\text { Yield (\%) } \\
\text { fold }\end{array}$ \\
\hline Crude extract & $19.0 \pm 1.3$ & $4,500 \pm 97$ & 237 & 100 & 1.0 \\
DEAE-Fractogel & $11.0 \pm 0.9$ & $3,920 \pm 66$ & 356 & 87.1 & 1.5 \\
Con A-Sepharose & $3.9 \pm 0.4$ & $2,340 \pm 51$ & 600 & 52.0 & 2.53 \\
\hline
\end{tabular}

Results are mean values of three replicates 


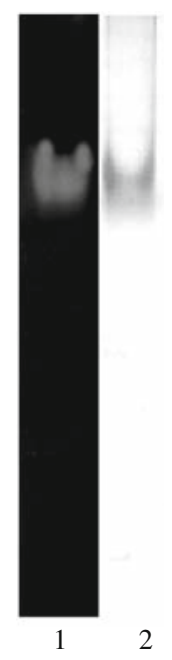

A

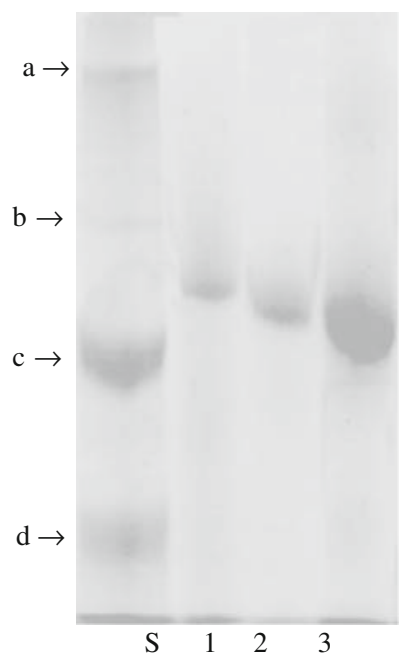

B
Fig. 1 Polyacrylamide gel electrophoresis and SDS-PAGE of purified glucoamylase. a PAGE of glycosylated GA: (lane Al) GA activity; (lane A2) GA developed by $\mathrm{AgNO}_{3}$. b SDS-PAGE of GA stained by Comassie Blue: $(S)$ standards of molecular mass ( $a$ myosin, $b$ phosphorylase, $c$ bovine serum albumin and $d$ ovoalbumin); (lane B1) glycosylated GA, (lane B2) deglycosylated GA after treatment with Endo-H; (lane B3) deglycosylated GA after treatment with PNGase F

stability against thermal and chemical denaturation [13]. Glucoamylase with glycoproteic structures is well documented for several filamentous fungi, where the carbohydrate content is typically in the range of $10-20 \%$. An exception appears to be the glucoamylase from Neurospora crassa, which has a reduced carbohydrate content of $5.1 \%$ [32]. The molecular masses of glucoamylases produced by filamentous fungi appear to vary considerably, not only among organisms, but also within different strains of the same species. The molecular masses of glucoamylases from several fungi are generally between 48 and $90 \mathrm{kDa}$ [25], although exceptions, such as the $125-\mathrm{kDa}$ glucoamylase produced by A. niger, have been reported [34]. The reduction of molecular mass of A. niveus glucoamylase observed after deglycosylation showed that the enzyme is a glycoprotein; however, further study is required to determine the structure and the role of the carbohydrate moiety.

The enzyme showed an excellent capacity for hydrolyzing different substrates and exhibited high affinity for soluble starch, glycogen, amylopectin, maltose, maltotriose and amylose (data not shown). The ability to hydrolyze longchain as starches and glycogen indicated that the enzyme was a glucoamylase. On the other hand, the lack of activity on $\alpha$-PNPG and sucrose indicated that the enzyme was not an $\alpha$-glucosidase. Additional evidence in favor of the amylolytic activity produced by $A$. niveus being a glucoamylase was the exclusive liberation of glucose as the end product from starch hydrolysis (Fig. 2).

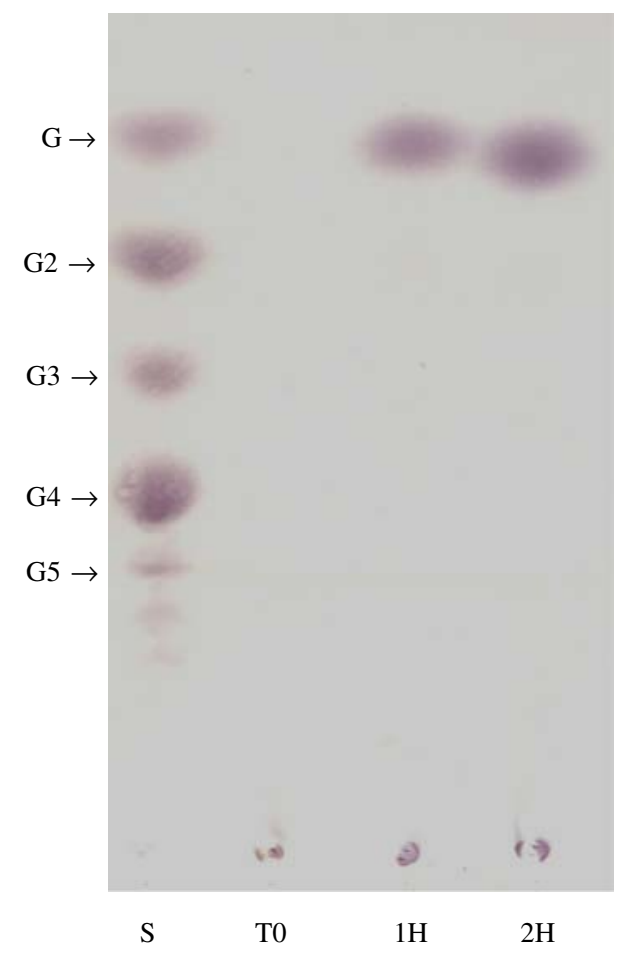

Fig. 2 Thin layer chromatography analysis of the end products of hydrolysis of purified GA under soluble starch: $S$ standard ( $G$ glucose, $G 2$ maltose, $G 3$ maltotriose, $G 4$ maltotetraose and $G 5$ maltopentaose); TO zero time of assay; $1 H 1 \mathrm{~h}$ of hydrolysis and $2 \mathrm{H} 2 \mathrm{~h}$ of hydrolysis

The effect of $\mathrm{pH}$ on the enzyme activity is shown in Fig. 3a. The optimum for the enzyme activity was observed in $\mathrm{pH}$ 5.0-5.5, and the isoelectric point is 3.8 (see Table 2). Similar results were observed by Michelin et al. [23]. The acid $\mathrm{pH}$ optimum is similar to other fungal glucoamylases, for example, the glucoamylase produced by two lineages of A. terreus, which presented $\mathrm{pH}$ optimum of 4.0 and 5.0 [2, 11], respectively. The glucoamylase activity of A. niveus was acid-alkaline tolerant and remained stable over a $\mathrm{pH}$ range of 4.0-9.5 after $2 \mathrm{~h}$ incubation (Fig. 3b). The temperature optimum of the glucoamylase from A. niveus was $65^{\circ} \mathrm{C}$ (Fig. 3c), and maintained total activity after $240 \mathrm{~min}$ incubation at $60^{\circ} \mathrm{C}$ (data not shown). The enzyme presented an elevated temperature optimum and good thermostability, which are both substantially superior to the enzyme of Aspergillus sp AS-2 $\left(50^{\circ} \mathrm{C}\right)[30]$. This result reinforces the potential of this enzyme for applications in those processes that demand elevated temperatures. The kinetic analysis using soluble starch as substrate yielded a $K_{\mathrm{m}}$ value of $0.32 \pm 0.05 \mathrm{mg} \mathrm{ml}^{-1}$ (Table 2). The enzyme exhibited high affinity for starch, presenting a $K_{\mathrm{m}}$ that was lower than that reported for the glucoamylase from A. niger (1.48 $\left.\mathrm{mg} \mathrm{ml}^{-1}\right)$ [19].

Many fungal amylases described in the literature are activated by metal ions, and the glucoamylase from $\mathrm{A}$. niveus showed a slight activity increase in the presence of low 
Fig. 3 Effect of $\mathrm{pH}$ and temperature in the glucoamylase activity and stability. a Effect of $\mathrm{pH}$, b enzyme stability as a function of $\mathrm{pH}$ and $\mathbf{c}$ effect of temperature
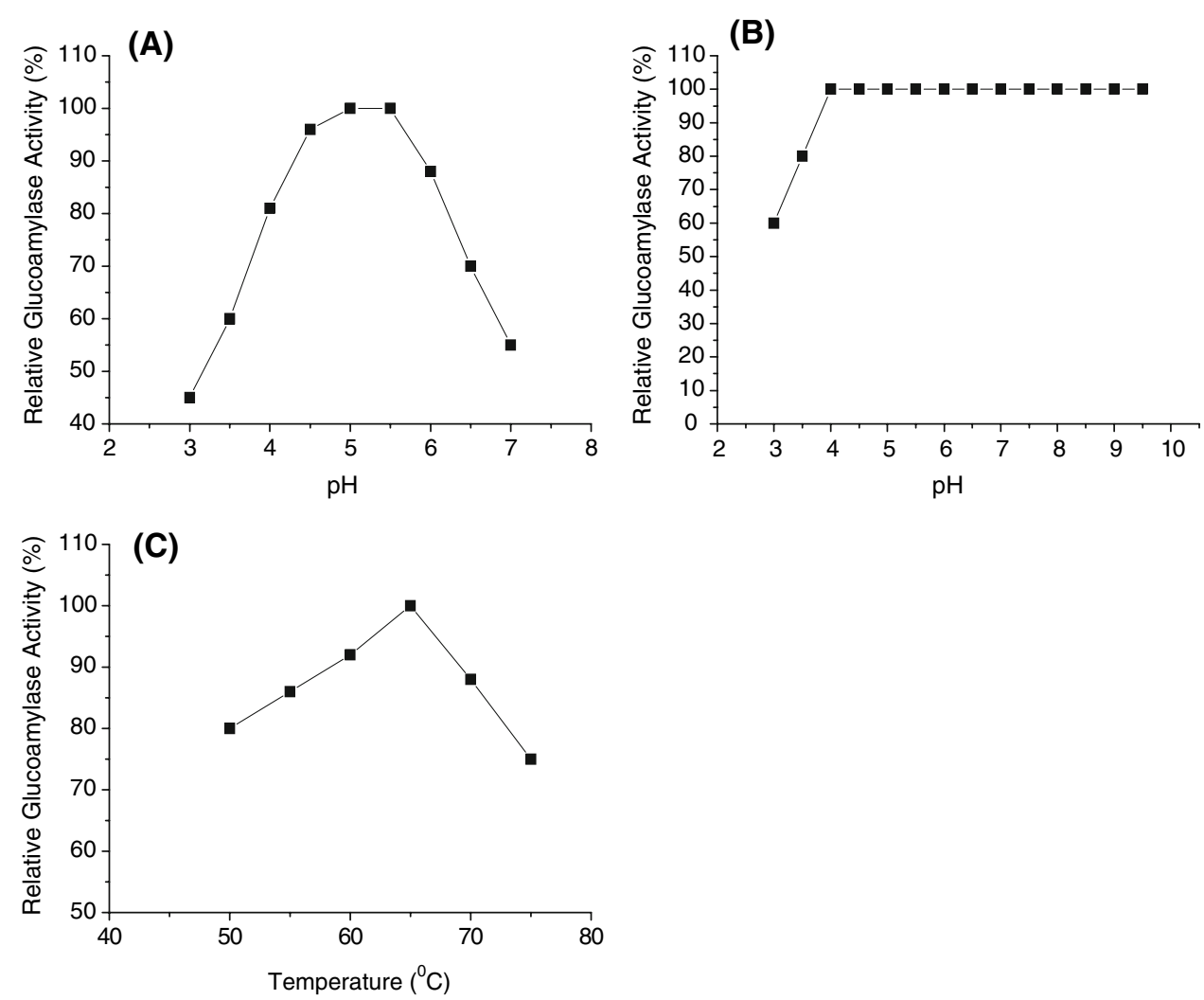

Table 2 Biochemical and physical-chemical properties of the glucoamylase purified from $A$. niveus

\begin{tabular}{ll}
\hline Properties & Values \\
\hline Molecular mass & \\
$\quad$ SDS-PAGE glycosylated glucoamylase & $77.0 \pm 0.5$ \\
$\quad$ SDS-PAGE enzyme-treated PNGase $\mathrm{F}$ & $68.0 \pm 0.6$ \\
$\quad$ Gel filtration & $76 \pm 0.2$ \\
Optimum pH & $5.0-5.5$ \\
$\mathrm{pH}$, stability $2 \mathrm{~h}$ & $4.0-9.5$ \\
Optimum temperature $\left({ }^{\circ} \mathrm{C}\right)$ & 65 \\
Temperature stability-4 h at $60^{\circ} \mathrm{C}(\%)$ & 100 \\
$K_{\mathrm{m}}\left(\mathrm{mg} \mathrm{ml}^{-1}\right)$ & $0.32 \pm 0.05$ \\
$V_{\text {max }}\left(\mathrm{U} / \mathrm{mg}^{-1}\right.$ protein $)$ & $237.0 \pm 25$ \\
$K_{\text {cat }}\left(\mathrm{s}^{-1}\right)$ & 14.2 \\
$K_{\text {cat }} / K_{\mathrm{m}}\left(\mathrm{s}^{-1} \mathrm{mg}^{-1} \mathrm{ml}\right)$ & 44.4 \\
Carbohydrate content $(\%)$ & $11 \pm 0.2$ \\
Isoelectric point & 3.8 \\
\hline
\end{tabular}

Results are mean values of three replicates

concentrations of most of the metallic ions tested (Table 3), with the exception of $\mathrm{Ag}^{+}$and $\mathrm{Fe}^{+2}$, which inhibited the activity by 21 and $5 \%$, respectively. This inhibition is a property in common with two sacharogenic amylases from Rhizomucor pusillus A 13.36, which are inhibited 88 and $46 \%$, respectively [29]. The presence of $1.0 \mathrm{mM}$ of all metallic ions slightly increased the enzyme activity. It was interesting that $1-30 \% \mathrm{NaCl}$ did not inhibit the activity glucoamylase (data not shown), since the use of this enzyme in processes at high salt concentrations might decrease contamination risks.

Table 4 shows the glucoamylase activity in the presence of organic solvents. The glucoamylase remained completely active in the presence of $10 \%$ methanol and acetone, and in the presence of isopropyl alcohol and ethanol (10\%) the enzyme maintained a high activity (86\%), as compared to the control.

There are few reports with respect to the effect of organic solvent on fungal enzymes, although the effects on a prokaryotic enzyme have recently been reported [9]. Some prokaryotes are able to grow in the presence of organic solvents, and the amylases produced by these organisms are organic-solvent-stable. Organic solvents may affect the conformation of the enzyme by displacement of water molecules either on the surface or at the catalytic site [17]. Glycosylation in eukaryotic enzymes has a stabilizing function and may have a protective effect on the enzyme catalytic site against conformational change caused by organic solvents. The activity in organic solvents observed by the glucoamylase from A. niveus may be of industrial interest, since both acetone and ethanol are used as precipitants for the concentration of commercial enzymes. Furthermore, the addition of ethanol can also improve the overall economics of a process by reducing bacterial contamination. 
Table 3 Effect of metal ions, EDTA and $\beta$-mercaptoethanol in glucoamylase activity

\begin{tabular}{lll}
\hline Ions & \multicolumn{2}{l}{ Relative activity $(\%)$} \\
\cline { 2 - 3 } & $1 \mathrm{mM}$ & $10 \mathrm{mM}$ \\
\hline $\mathrm{CaCl}_{2}$ & $112( \pm 0.4)$ & $128( \pm 0.2)$ \\
$\mathrm{BaCl}_{2}$ & $112( \pm 0.2)$ & $106( \pm 0.4)$ \\
$\mathrm{NH}_{4} \mathrm{~F}$ & $105( \pm 0.5)$ & $112( \pm 0.5)$ \\
$\mathrm{NaBr}$ & $122( \pm 0.3)$ & $109( \pm 0.3)$ \\
$\mathrm{KH}_{2} \mathrm{PO}_{4}$ & $115( \pm 0.2)$ & $106( \pm 0.3)$ \\
$\mathrm{MnCl}_{2} \cdot 4 \mathrm{H}_{2} \mathrm{O}$ & $115( \pm 0.2)$ & $88( \pm 0.2)$ \\
$\mathrm{MgCl}_{2} \cdot 6 \mathrm{H}_{2} \mathrm{O}$ & $111( \pm 0.2)$ & $97( \pm 0.4)$ \\
$\mathrm{NH}_{4} \mathrm{Cl}_{\mathrm{CuCl}}$ & $124( \pm 0.4)$ & $118( \pm 0.3)$ \\
$\mathrm{KCl}$ & $128( \pm 0.5)$ & $115( \pm 0.5)$ \\
$\mathrm{AgNO}_{3}$ & $105( \pm 0.4)$ & $95( \pm 0.1)$ \\
$\mathrm{Fe}_{2}\left(\mathrm{SO}_{4}\right)_{2}$ & $79( \pm 0.4)$ & $51( \pm 0.1)$ \\
$\mathrm{ZnCl}_{2}$ & $95( \pm 0.3)$ & $52( \pm 0.3)$ \\
$\mathrm{CoCl}_{2} \cdot 6 \mathrm{H}_{2} \mathrm{O}$ & $114( \pm 0.2)$ & $88( \pm 0.4)$ \\
$\mathrm{NaH}_{2} \mathrm{PO}_{4} \cdot \mathrm{H}_{2} \mathrm{O}$ & $116( \pm 0.4)$ & $122( \pm 0.5)$ \\
$\beta-\mathrm{Mercaptoethanol}_{\mathrm{EDTA}}$ & $117( \pm 0.5)$ & $117( \pm 0.5)$ \\
$\mathrm{NaCl}$ & $114( \pm 0.4)$ & $100( \pm 0.4)$ \\
\hline $\mathrm{Resuls}$ & $100( \pm 0.3)$ & $94( \pm 0.4)$ \\
& $135( \pm 0.4)$ & $105( \pm 0.3)$ \\
\hline
\end{tabular}

Results are mean values of three replicates. Control $(660 \mathrm{U} / \mathrm{mg}$ protein) was considered as $100 \%$

Table 4 Effect of organic solvents in the glucoamylase activity

\begin{tabular}{llll}
\hline Solvent & $5 \%$ & $10 \%$ & Polarity indicate \\
\hline Control & 100 & 100 & 10.0 \\
Ethyl acetate & $79( \pm 0.1)$ & 0 & 4.3 \\
$N$-Butyric alcohol & $100( \pm 0.2)$ & $30( \pm 0.2)$ & 3.9 \\
Isopropyl alcohol & $100( \pm 0.4)$ & $86( \pm 0.1)$ & 9.3 \\
Ethanol & $100( \pm 0.4)$ & $86( \pm 0.2)$ & 5.2 \\
Formaldehyde & $53( \pm 0.1)$ & 0 & - \\
Methanol & $100( \pm 0.3)$ & $100( \pm 0.3)$ & 6.6 \\
Acetone & $116( \pm 0.4)$ & $100( \pm 0.2)$ & 5.4 \\
\hline
\end{tabular}

Results are mean values of three replicates

Dichroism circular and amino acid sequence analysis

The far ultraviolet circular dichroism spectra of the glucoamylase purified from A. niveus (Fig. 4) presents a minimum at 207, a pronounced shoulder at $220 \mathrm{~nm}$ and a maximum at $192 \mathrm{~nm}$. These features of the spectrum indicate that the purified protein possesses high $\alpha$-helical content, and an estimate of the secondary structure content of the protein yields values of $33 \% \alpha$-helix, $17 \% \beta$-sheet and $50 \%$ disordered coil, and indicates that the purification protocol yielded protein with native-like secondary structure.

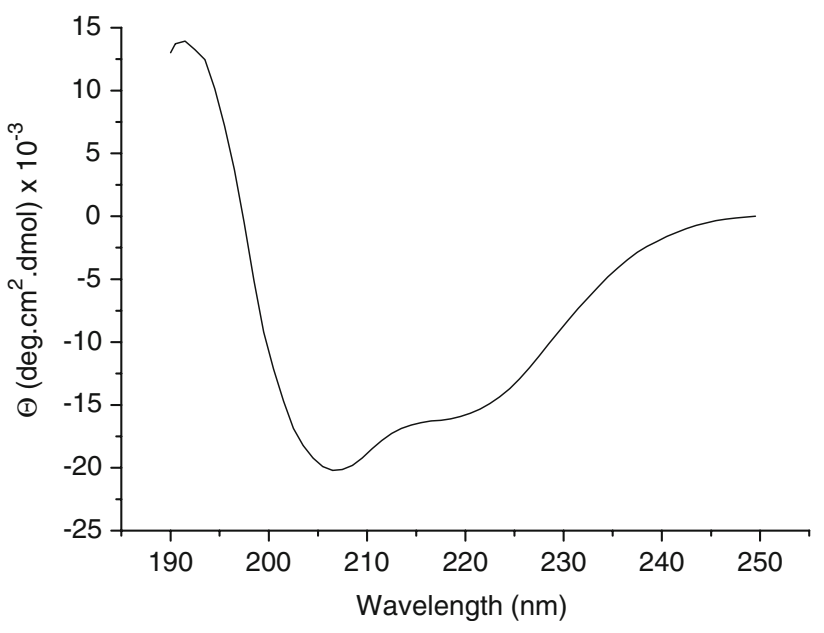

Fig. 4 Far-UV CD spectra of the glucoamylase purified from A. niveus. The molar ellipticity $(\Theta)$ was calculated assuming that the $A$. niveus glucoamylase presents a high degree of sequence similarity with glucoamylases from other Aspergillus species. See "Materials and methods" for further experimental details

Table 5 N-Terminal sequence analysis of purified glucoamylase of A. niveus and comparison with other Aspergillus sp glucoamylases

\begin{tabular}{lll}
\hline Fungi & Sequence and position & Homology (\%) \\
\hline A. terreus & SPRAL (299-303) & 100 \\
A. niger & SPRAL (295-299) & 100 \\
A. ficcum & SPRAL (295-299) & 100 \\
A. awamori & SPRAL (294-298) & 100 \\
A. kawachi & SPRAL (294-298) & 100 \\
A. shirousami & SPRAL (294-298) & 100 \\
\hline
\end{tabular}

SPRAL corresponds at Ser, Pro, Arg, Ala and Leu, respectively

Tryptic amino acid sequence analysis of glucoamylase from A. niveus was Ser-Pro-Arg-Ala-Leu (SPRAL) showing $100 \%$ identity with glucoamylases from A. niger, A. kawachi, A. ficcum, A. terreus, A. awamori and A. shirousami, as shown in the Table 5 .

The secondary structure content estimate of the protein was based on the assumption that the protein shares a high degree of amino acid sequence similarity with the glucoamylases from other Aspergillus species, and the tryptic peptide sequence is consistent with this. The number of amino acids used to calculate the molar ellipticity was therefore taken to be 614 for the full length mature protein, which is consistent with the molecular mass of the protein after PNGase $\mathrm{F}$ treatment. Analysis of the full length amino acid sequence of the glucoamylases from different Aspergillus species reveals that the $\mathrm{N}$-terminal region of the proteins (residues 36-441) shows high similarity $\left(E=1 \mathrm{e}^{-115}\right)$ with proteins from the glucosyl hydrolase family 15 (pfam00723), and the C-terminal regions (residues 546633) are highly similar $\left(E=3 \mathrm{e}^{-28}\right)$ to the starch binding 
domain family (pfam00686). The three-dimensional structures of both the glucosyl hydrolase region and the starch binding domain have been determined separately from A. awamori (PDB code 3GLY, [1]) and A. niger (1KUM, [31]), respectively, and together include 576 of the estimated 615 residues, thereby covering $94 \%$ of the total protein. Analysis of the total secondary structure content of these experimentally determined structures gives values of $38 \% \alpha$-helix, $17 \% \beta$-sheet and $45 \%$ disordered coil. These values correlate well with the values $33 \% \alpha$-helix, $17 \%$ $\beta$-sheet and 50\% disordered coil as estimated from analysis of the far ultraviolet circular dichroism spectrum of the glucoamylase from A. niveus.

Then, all analyzed properties and structural studies classified A. niveus as a potential thermotolerant fungus with high glucoamylase levels, which might have great possibilities for industrial application.

Acknowledgments This work was supported by grants from Fundação de Amparo à Pesquisa do Estado de São Paulo (FAPESP) and Conselho de Desenvolvimento Científico e Tecnológico (CNPQ). J. A. Jorge, H. F. Terenzi and M. L. T. M. Polizeli are Research Fellows of CNPq. T. M. Silva is recipient FAPESP Fellowship and this work was part of a Doctor Thesis submitted by T. M. Silva to FFCLRPUSP. We thank Ricardo F. Alarcon and Mauricio de Oliveira for technical assistance.

\section{References}

1. Aleshin AE, Hoffman C, Firsov LM, Honzatko RB (1994) Refined crystal structures of glucoamylase from Aspergillus awamori var. X100. J Mol Biol 238:575-591

2. Ali S, Hossain Z (1991) Characteristics for glucoamylase from Aspergillus terreus. J Appl Bacteriol 71:144-146

3. Andrade MA, Chacon P, Merelo JJ, Moran F (1993) Evaluation of secondary structure of proteins from UV circular dichroism spectra using an unsupervised learning neural network. Protein Eng Des Sel 6:383-390

4. Aquino AC, Jorge AJ, Terenzi HF, Polizeli MLTM (2003) Studies on thermostable $\alpha$-amylase from thermophilic fungus Scytalidium thermophilum. Appl Microbiol Biotechnol 61:323-328

5. Davis BJ (1964) Disc electrophoresis II. Methods and application to human serum proteins. Ann NY Acad Sci 121:404-427

6. Deléage G, Geourjon C (1993) An interactive graphic program for calculating the secondary structures content of proteins from circular dichroism spectrum. Comput Appl Biosci 9:197199

7. Doukyu N, Aono R (2001) Cloning, sequence analysis and expression of a gene encoding an organic solvent and detergent-tolerant cholesterol oxidase of Burkholderia cepacia strain ST-200. Appl Microbiol Biotechnol 57:146-152

8. Doukyu N, Aono R, Kuwahara H (2003) Isolation of Paenibacillus illinoisensis that produces cyclodextrin glucanotransferase resistant to organic solvents. Biosci Biotechnol Biochem 67:334340

9. Doukyu N, Yamagishi W, Kuwahara H, Ogino H, Furuki N (2007) Purification and characterization of a maltooligosaccharide-forming amylase that improves product selectivity in water-miscible organic solvents, from dimethylsulfoxide-tolerant Brachybacterium sp. strain LB25. Extremophiles 11(6):781-788
10. Fukushima T, Mizuki T, Echigo A, Inoue A, Usami R (2005) Organic solvent tolerance of halophilic $\alpha$-amylase from a Haloarchaeon Haloarcula sp. Strain S-1. Extremophiles 9:85-89

11. Ghosh AB, Chatterjee B, Das A (1991) Purification and characterization of glucoamylases of Aspergillus terreus NA-170 mutant. J Appl Bacteriol 71:162-169

12. Imai Y, Sukura M, Masamoto M, Nagayasu K (1994) Glucoamylase production of Aspergillus oryzae in fed-batch culture using a statistical regression model. J Ferment Bioeng 78:310-314

13. Jafari-Aghdam J, Khajeh K, Ranjbar B, Netmat-Gorgani M (2005) Deglycosylation of glucoamylase from Aspergillus niger: effect on structure, activity and stability. Biochim Biophys Acta 1750:6168

14. Kaur P, Satyanarayana T (2004) Production and saccharification by a thermostable and neutral glucoamylase of a thermophilic mould Thermomucor indicae-seudaticae. J Microbiol Biotechnol 20:419-425

15. Kelly CT, Giblin M, Forgarty WM (1986) Resolution, purification and characterization of two extracellular glucohydrolases, $\alpha$-glucosidase and maltase of Bacillus licheniformis. Can J Microbiol 32:342-347

16. Khanna P, Sundari SS, Kumar NJ (1995) Production, isolation and partial purification of xylanase from Aspergillus sp. World J Microbiol Biotechnol 11:242-243

17. Klibanov A (1997) Why are enzymes less active in organic solvents than in water? Trends Biotechnol 15:97-101

18. Laemmli UK (1970) Cleavage of structural proteins during the assembly of head of bacteriophage T4. Nature 227:680-685

19. Lee CK, Le QT, Kim YH, Shim JH, Lee SJ, Park JH, Lee KP, Song SH, Auh JH, Lee SJ, Park KH (2008) Enzymatic synthesis and properties of highly branched rice starch amylose and amylopectin cluster. J Agric Food Chem 56(1):126-131

20. Leone FA, Baranauskas JA, Ciancaglini P (1995) Enzyplot: a microcomputer assistant program for teaching enzyme kinectis. Biochem Educ 23:35-37

21. Lowry O, Rosebrough N, Farr A, Randall R (1951) Protein measurement with the folin phenol reagent. J Biol Chem 193:265-275

22. Meagher MM, Nikolov ZL, Reilly PJ (1989) Subsite mapping of Aspergillus niger glucoamylases I and II with malto- and isomaltooligosaccharides. Biotechnol Bioeng 34:681-688

23. Michelin M, Ruller R, Ward RJ, Moraes LAB, Jorge JA, Terenzi HF, Polizeli MLTM (2008) Purification and biochemical characterization of a thermostable extracellular glucoamylase produced by the thermotolerant fungus Paecilomyces variotii. J Ind Microbiol Biotechnol 35:17-25

24. Miller GL (1959) Use of dinitrosalicylic acid reagent for determination of reducing sugars. Anal Chem 31:426-428

25. Norouzian D, Azim A, Jeno MS, Murrauy MY (2006) Fungal glucoamylases, review. Biotechnol Adv 44:80-85

26. Ogino H, Miyamoto K, Ishikawa H (1994) Organic-solventtolerant bacterium which secrets organic-solvent-stable lipolytic enzyme. Appl Environ Microbiol 64:1929-1932

27. Ogino H, Yasui K, Shinotani T, Ishihara T, Ishikawa H (1995) Organic-solvent-tolerant bacterium which secrets organicsolvent-stable proteolytic enzyme. Appl Environ Microbiol 61:4258-4262

28. Pandey A, Nigam P, Soccol CR, Soccol VT, Singh D, Mohan R (2000) Advances in microbial amylases. Review. Biotechnol Appl Biochem 31:135-152

29. Silva TM, Attili-Angelis D, Carvalho AFA, Da Silva R, Gomes E (2005) Production of sacharogenic and dextrinogenic amylases by Rhizomucor pusillus A 13.36. J Microbiol 43:561-568

30. Soni KS, Gupta KJ (2003) A solid state fermentation based bacterial $\alpha$-amylase and fungal glucoamylase system and its suitability for the hydrolysis of wheat starch. Process Biochem 39:185-192 
31. Sorimachi K, Jacks AJ, Le Gal-Coëffet MF, Williamson G, Archer DB, Williamson MP (1996) Solution structure of the granular starch binding domain of glucoamylase from Aspergillus niger by nuclear magnetic resonance spectroscopy. J Mol Biol 259:970987

32. Spinelli BBL, Polizeli MLTM, Jorge AJ, Terenzi HF (1996) Biochemical characterization of glucoamylase from the hyper producer exo-1 mutant strain of Neurospora crassa. FEMS Microbiol Lett 138:173-177
33. Sukura E, Doelle HW (1989) A one step process for the production of single cell protein and amyloglucosidase. Appl Microbiol Biotechnol 30:135-140

34. Suresh C, Dubey AK, Srikanta S, Kumar US (1999) Characterization of starch hydrolysing of Aspergillus niger. Appl Microbiol Biotechnol 51:673-675

35. Vihinen M, Mantsala P (1989) Microbial amylolytic enzymes. Crit Rev Biochem Mol Biol 24(4):329-418 